\title{
ipen
}

AUTARQUIA ASSOCIADA À UNIVERSIDADE DE SÃO PAULO

Caracterização de um dispositivo de ensaio para determinação da camada semiredutora e da filtração com equivalência de qualidade da norma ABNT NBR IEC 60601-1-3

\section{Vlamir Viana}

Dissertação apresentada como parte dos requisitos para obtenção do Grau de Mestre em Ciências na Área de Tecnologia Nuclear - Aplicações

Orientadora:

Profa. Dra. Maria da Penha Albuquerque Potiens 
INSTITUTO DE PESQUISAS ENERGÉTICAS E NUCLEARES

Autarquia associada à Universidade de São Paulo

CARACTERIZAÇÃO DE UM DISPOSITIVO DE ENSAIO PARA DETERMINAÇÃO DA CAMADA SEMIRREDUTORA E DA FILTRAÇÃO COM EQUIVALÊNCIA DE QUALIDADE DA NORMA ABNT NBR IEC 60601-1-3

VLAMIR VIANA

Dissertação apresentada como parte dos requisitos para obtenção do grau de Mestre em Ciências na Área de Tecnologia Nuclear - Aplicações

Orientadora:

Dra. Maria da Penha Albuquerque Potiens

SÃO PAULO 


\section{DEDICATÓRIA}

Dedico este trabalho com todo amor àqueles que são a fonte de inspiração da minha vida, minha esposa Adriana e aos meus filhos Natalia e João Vitor 


\section{AGRADECIMENTOS}

A Dra. Maria da Penha Albuquerque Potiens, pela amizade, orientação, confiança e apoio em todas as etapas do desenvolvimento deste trabalho.

Ao amigo Márcio Bottaro, chefe da STEEE, grande incentivador deste trabalho.

Ao amigo Iremar Alves, pela amizade e troca de informações durante toda a jornada deste mestrado.

A Fernanda Cristina Salvador Soares pela troca de informações relacionadas à portaria 453, que abordam o controle de qualidade em equipamentos de raios $X$.

A bolsista da FINEP Marina Batalim pelo auxilio na realização das medições utilizadas neste trabalho.

Amigo e bolsista do SIBRATEC Danilo Cabral Rosendo pelo auxilio na confecção da placa de circuito impresso.

À Ana Cláudia de Azevedo Alcântara pelo companheirismo e trocas de informações.

Elaine Aparecida Ferreira Benetti pelo auxilio na revisão do texto e da formatação da dissertação.

Ao Mauricio Landi da oficina mecânica do IEE/USP pela confecção do suporte mecânico dos drives de CD.

Ao amigo Edson Pereira Barbosa pelo auxilio na montagem do dispositivo que foi desenvolvido.

Ao amigo Paulo Lucas Dantas Filho do IEE/USP que viabilizou a doação dos drives de CD utilizados no trabalho.

Ao Sr. Leonardo Calixto Antunes da empresa Philips Medical do Brasil, que viabilizou a doação do gerador de raios $\mathrm{X}$ modelo Pulsar Plus, parte integrante do dispositivo desenvolvido neste trabalho.

Ao Dr. Marco A. G. Pereira, chefe da STDTS, que disponibilizou o equipamento de raios X industrial da Philips, utilizado como referência neste trabalho.

A equipe da CPG do IPEN pelo suporte sempre com grande cordialidade.

Aos funcionários do IEE/USP que de forma direta ou indireta colaboraram com este trabalho.

A Financiadora de Estudos e Projetos (FINEP), pelo aporte dos recursos relacionados ao projeto SELER, cujos equipamentos adquiridos foram utilizados neste trabalho.

A minha esposa Adriana e meus filhos Natalia e João Vitor pelo apoio, incentivo, paciência, pois, sacrificaram o tempo precioso da nossa convivência familiar para eu pudesse realizar este trabalho.

A minha família que sempre acreditou que eu pudesse chegar até aqui, especialmente a minha mãe Maria José que, ante as dificuldades impostas pela vida, nunca esmoreceu em nos conduzir, eu e meus irmãos Vânia e Vandré, no caminho dos estudos e do bem. A meu pai Nelson (In Memoriam) que, apesar da pouca convivência, deixou ensinamentos essenciais para a minha vida terrena: o caráter, a integridade, a honestidade, a responsabilidade e o compromisso com as pessoas e com o trabalho.

Agradeço a Deus e a meu mentor espiritual por sempre terem me dado todas as oportunidades de evolução, por menor que tenha sido o meu aproveitamento delas. 
EPÍGRAFE

"O conhecimento é o processo

de acumular dados, a sabedoria reside na sua simplificação."

Martin H. Fischer 


\section{CARACTERIZAÇÃO DE UM DISPOSITIVO DE ENSAIO PARA DETERMINAÇÃO DA CAMADA SEMIRREDUTORA E DA FILTRAÇÃO COM EQUIVALÊNCIA DE QUALIDADE DE ACORDO COM A NORMA ABNT NBR IEC 60601-1-3}

\section{VLAMIR VIANA}

\section{RESUMO}

A motivação deste trabalho foi o desenvolvimento e validação de um dispositivo para realizar os testes estabelecidos na ABNT NBR IEC 60601-1-3 nas versões publicadas de $2001^{[1]}$ e $2011^{[2]}$. A finalidade dos ensaios é determinar a camada semirredutora - CSR (Half Value Layer - HVL) e a filtração com equivalência de qualidade, em mmAl, dos materiais que interceptam o feixe de raios $X$ desde a sua emissão até o dispositivo receptor de imagem de raios $X$. Esta filtração inclui os materiais presentes no conjunto fonte de radiação $X$, formado pela cúpula de proteção radiológica com o tubo de raios $\mathrm{X}$ inserido, pelo sistema de colimação (filtração inerente) e pelos materiais presentes nos suportes de pacientes, como mesa e bucky mural sendo que ambos incorporam dispositivo receptor de imagem que também é avaliado.

No desenvolvimento foi levada em consideração a rotina da execução do ensaio, com a finalidade de diminuir ao máximo a interação do operador com o sistema, a fim de reduzir o fator humano na execução, refletindo diretamente na incerteza de medição, na diminuição do tempo de execução e na segurança radiológica.

O dispositivo desenvolvido foi validado com relação aos seguintes aspectos:

a) Influência do dispositivo trocador de filtros quanto ao posicionamento e distribuição dos filtros;

b) Influência da pureza dos filtros de alumínio utilizados no dispositivo, e a

c) Comparação entre os ensaios realizados com dispositivo de ensaio desenvolvido com relação aos ensaios realizados com um gerador de raios $X$ de referência. 


\title{
CHARACTERIZATION OF A TEST DEVICE FOR DETERMINATION OF THE HALF VALUE LAYER AND OF FILTRATION WITH QUALITY EQUITY OF MATERIALS IN ACCORDANCE WITH STANDARD
}

ABNT NBR IEC 60601-1-3

\author{
VLAMIR VIANA
}

\begin{abstract}
The motivation of this work was the development and validation of a device to perform the tests established by ABNT NBR IEC 60601-1-3 versions published in $2001^{[1]}$ and $2011^{[2]}$. The purpose of the tests is to determine the half-value layer $\mathrm{HVL}$ and filtration with equivalent filtration quality in mmAl, materials that intercept the X-ray beam from their emission to the $X$-ray image receiving device. This filtration includes all the materials present in radiation source assembly, formed by the x-ray tube housing with x-ray tube inserted, the collimator (inherent filtration) and by materials present in the patients support, as Table and wall bucky, both incorporate image receiving device which is also evaluated.

In the development was taken in consideration the routine of tests execution routine, in order to reduce the operator interaction with the system and in order to reduce the human factor in the execution, reflecting directly on the measurement uncertainty, in the runtime reduction of the runtime and radiation safety.

The device was validated with respect to:

a) Effect of positioning and distribution of the filters in the filter changer device;

b) Influence of purity of the aluminum filter used in the device, and

c) Comparison tests carried out with the testing device with respect to the tests carried out with a reference $\mathrm{X}$-ray generator.
\end{abstract}




\section{SUMÁRIO}

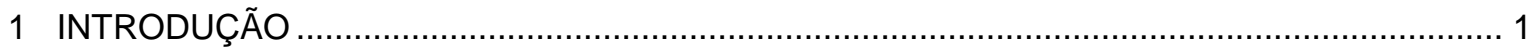

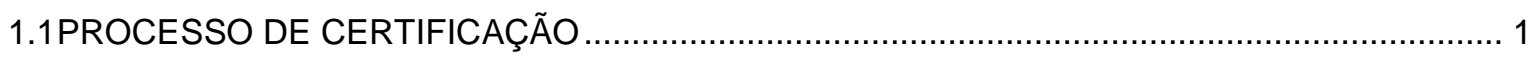

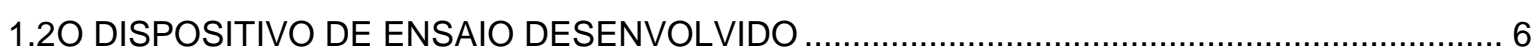

1.2.1 CRITÉRIOS PARA O DESENVOLVIMENTO DE UM DISPOSITIVO DE ENSAIO..... 8

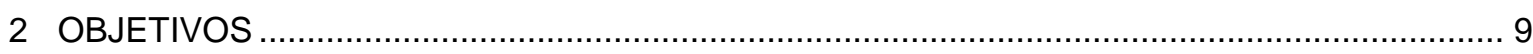

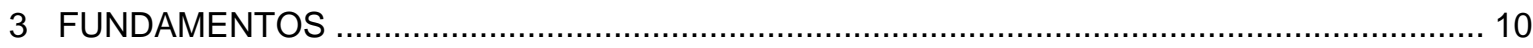

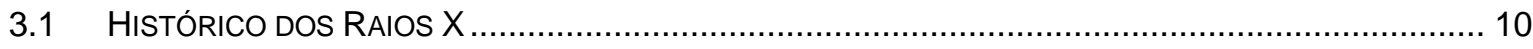

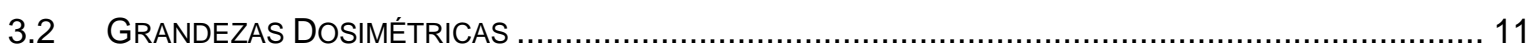

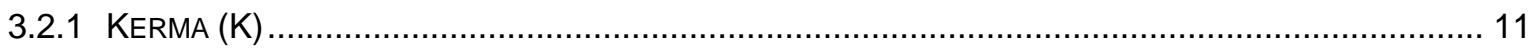

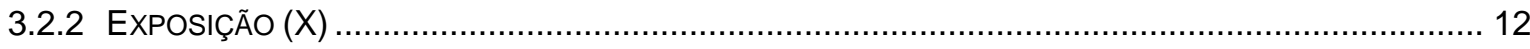

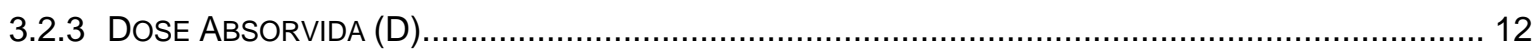

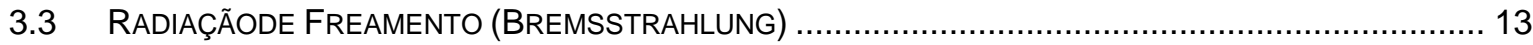

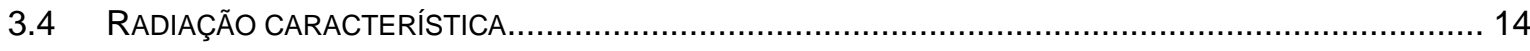

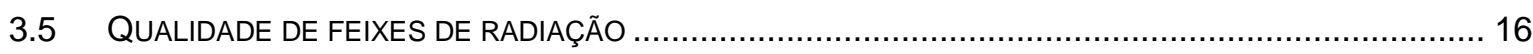

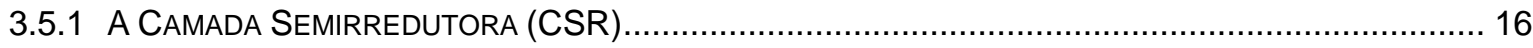

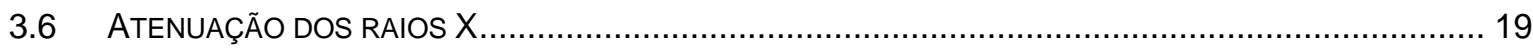

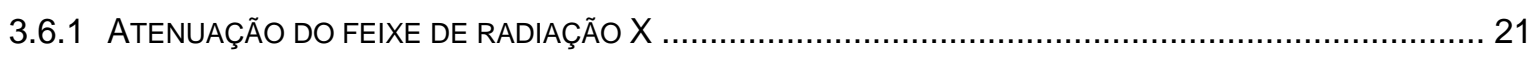

3.7 VARIAÇÃO NA QUALIDADE ATRAVÉS DE UM FEIXE DE RAIOS X ............................................. 23

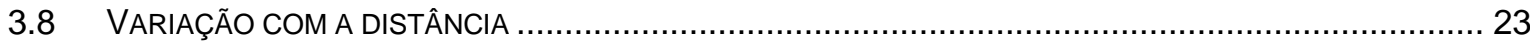

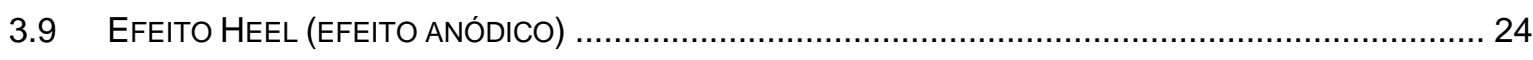

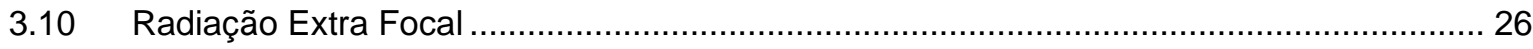

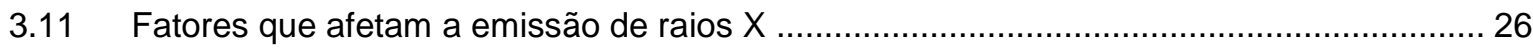

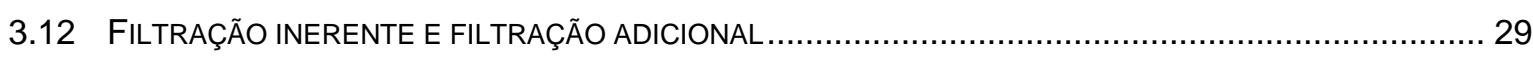

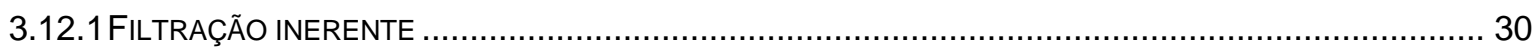

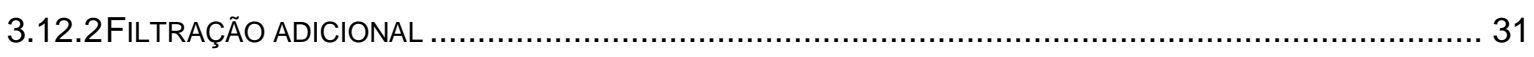

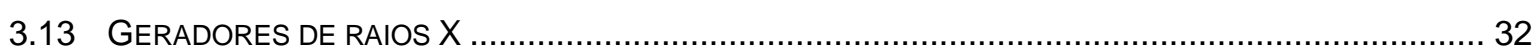

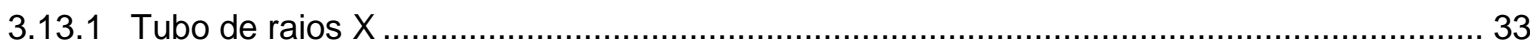

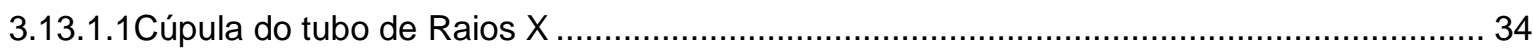

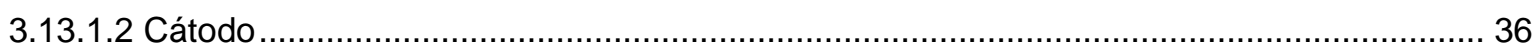

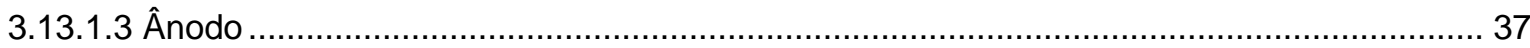

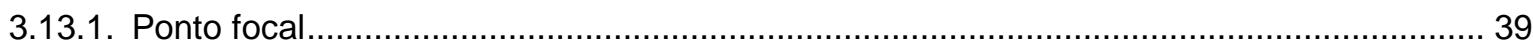

3.13.1. Ângulo do Ânodo e tamanho do ponto focal ................................................................. 39

3.13.1.6 Dispositivos limitadores de feixe (colimador) .......................................................... 43

3.14 Geradores Monofásicos e Trifásicos e de potencial constante ........................................ 43

3.14.1 Gerador de raios x monofásico ............................................................................... 44 


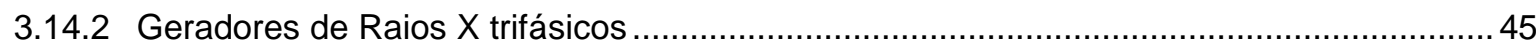

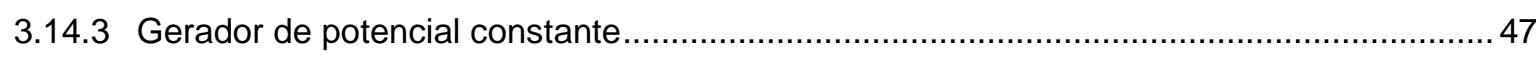

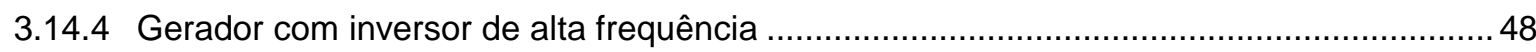

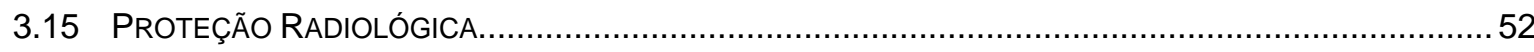

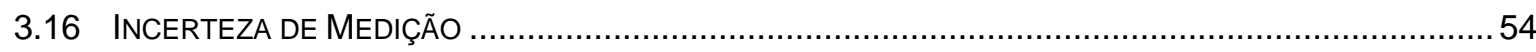

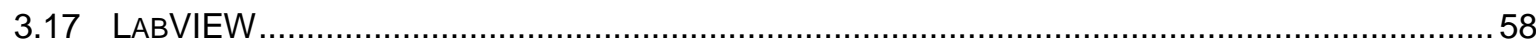

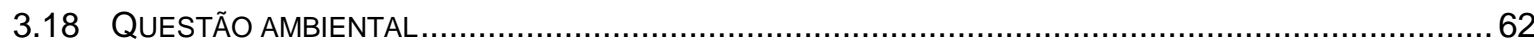

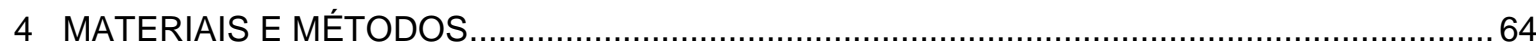

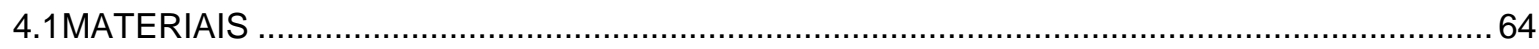

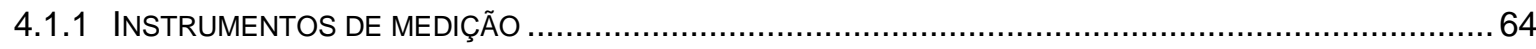

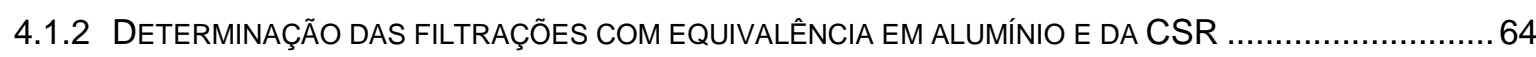

4.1.2.1 MONITORAÇÃO DOS PARÂMETROS DE APLICAÇÃO DE CARGA ….................... 65

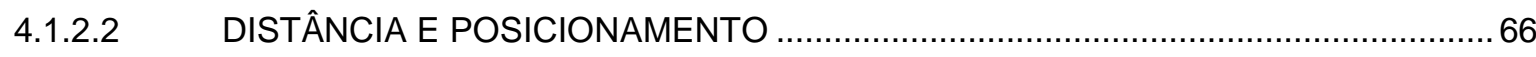

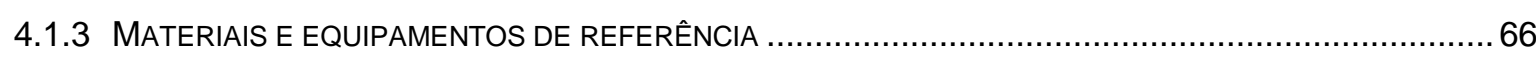

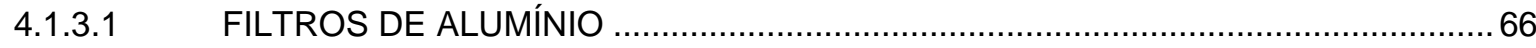

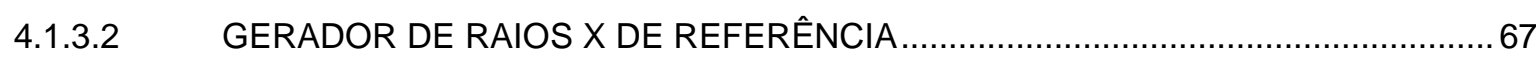

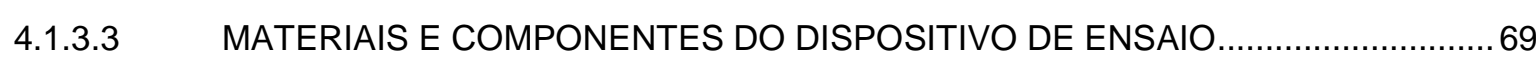

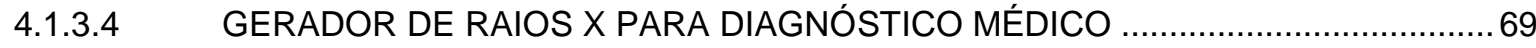

4.1.3.5 DISPOSITIVO LIMITADOR DE FEIXE ......................................................... 71

4.1.3.6 FILTROS DE ALUMÍNIO DE BAIXA PUREZA (99,5\% - TIPO 1100)........................... 72

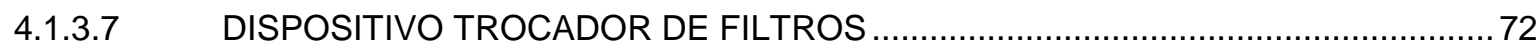

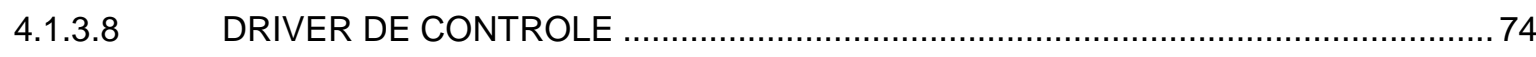

4.1.3.9 SOFTWARE DE CONTROLE DO DISPOSITIVO TROCADOR DE FILTROS ........... 78

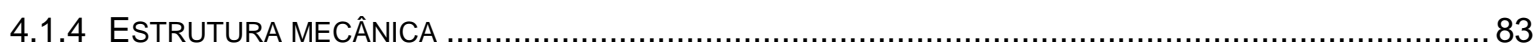

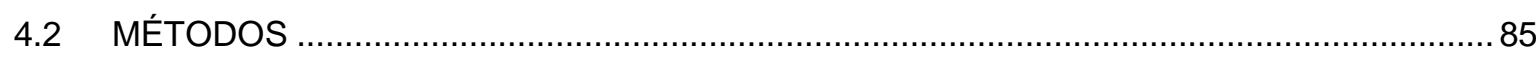

4.2.1 CRITÉRIOS PARA O DESENVOLVIMENTO DO DISPOSITIVO DE ENSAIO ........................................... 85

4.2.2 ESTAR DE ACORDO COM OS REQUISITOS DA ABNT NBR IEC 60601-1-3: E COM A NORMA IEC

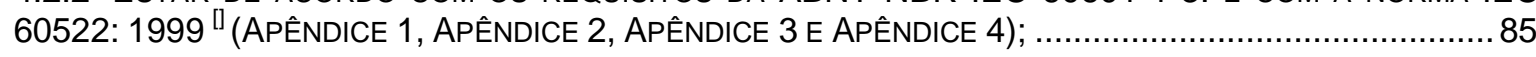

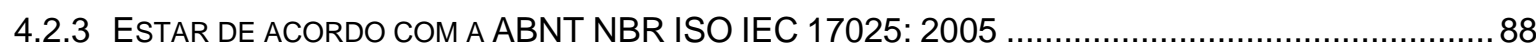

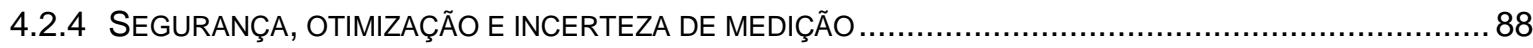

4.2.5 QUESTÃO AMBIENTAL - RECICLAGEM DE COMPONENTES (DRIVES DE CD) ……......................... 89

4.2.6 MÉTODO PARA DETERMINAÇÃO DA ATENUAÇÃO DOS MATERIAIS SEGUNDO A IEC 60522:1999 ...... 89

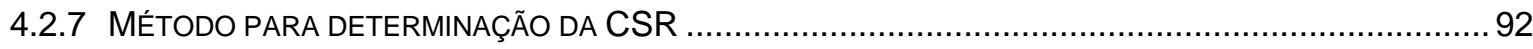

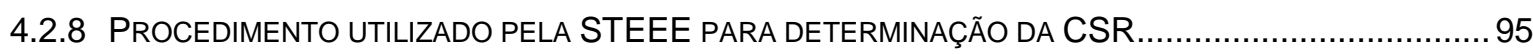

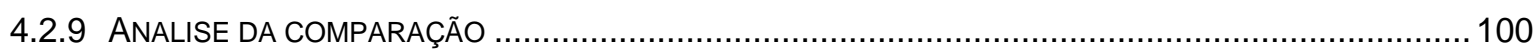

4.2.10PROCEDIMENTO UTILIZADO PELA STEEE PARA DETERMINAÇÃO DA FILTRAÇÃO DOS MATERIAIS COM

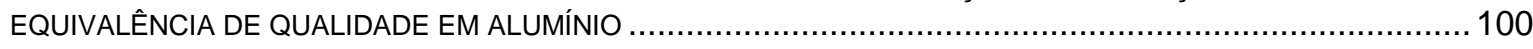

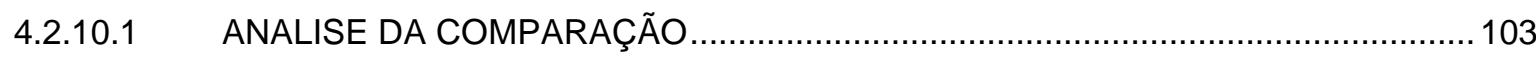

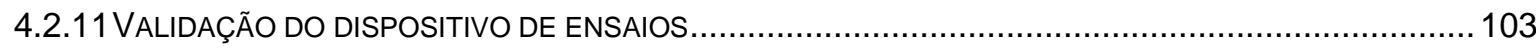

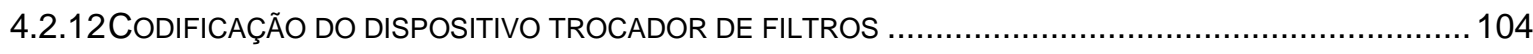

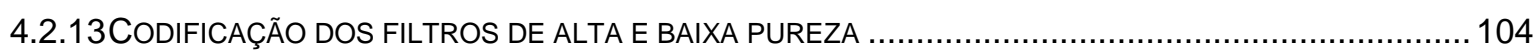




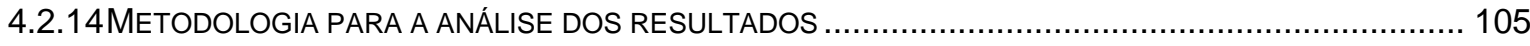

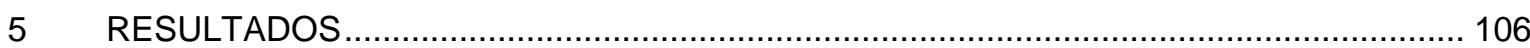

5.1 VALIDAÇÃO DO DISPOSITIVO TROCADOR DE FILTROS COM RELAÇÃO AO POSICIONAMENTO E PUREZA

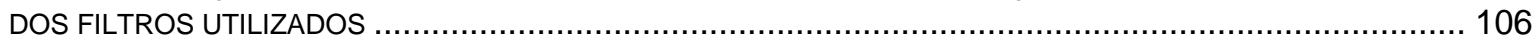

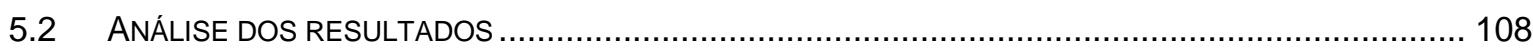

5.3 VALIDAÇÃO DO DISPOSITIVO TROCADOR DE FILTROS COM RELAÇÃO À RADIAÇÃO ESPALHADA ..... 110

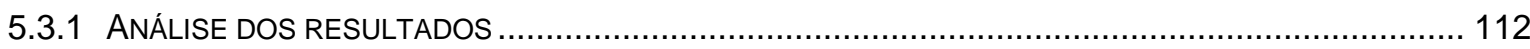

5.4 VALIDAÇÃO DO DISPOSITIVO DE ENSAIO PARA A DETERMINAÇÃO DA CSR - CLÁUSULA 29.201.9

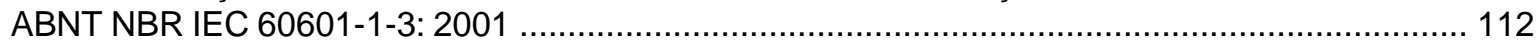

5.4.1 VERIFICAÇÃO DA INFLUÊNCIA NO POSICIONAMENTO DOS FILTROS NA DETERMINAÇÃO DA CSR ... 112

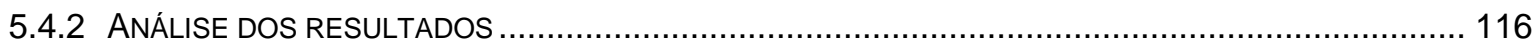

5.5 VALIDAÇÃO DO DISPOSITIVO DE ENSAIO DE ACORDO COM A IEC 60522: 1999 ........................... 116

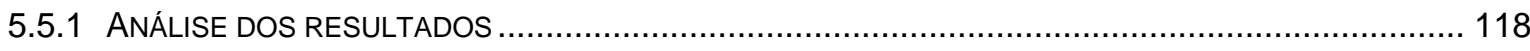

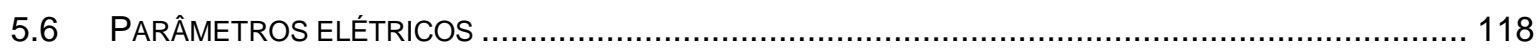

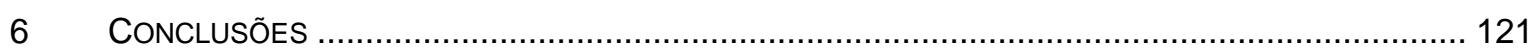

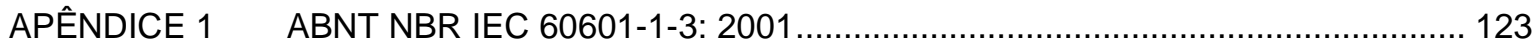

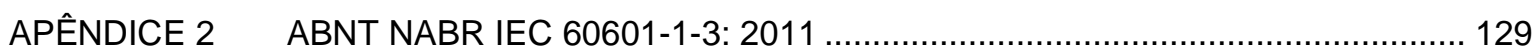

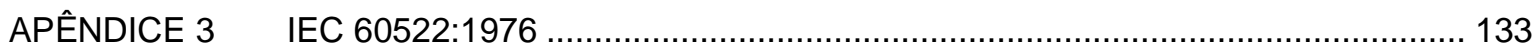

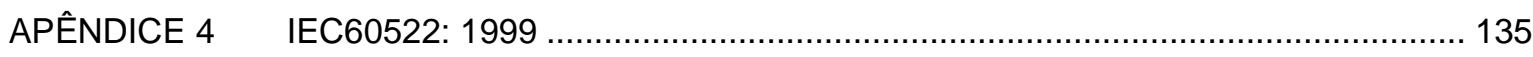

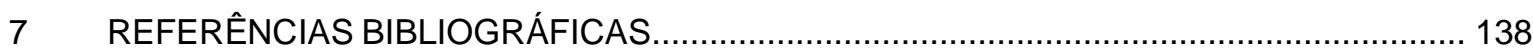




\section{ÍNDICE DE FIGURAS}

Figura 1 - Passos do processo de certificação .................................................................... 2

Figura 2 - Aplicação das normas em um equipamento de raios $X$ convencional ............................. 5

Figura 3. Colisão entre elétron de energia $E_{1}$ e núcleo do átomo do alvo ${ }^{[18]}$................................ 13

Figura 4 - Espectros de raios $X$ produzidos para aplicação diagnóstica ${ }^{[18]}$. ................................... 14

Figura 5 -. O processo de interação para a produção da radiação característica ............................ 14

Figura 6 -. Produção de raios $X$ por conversão de energia.......................................................... 15

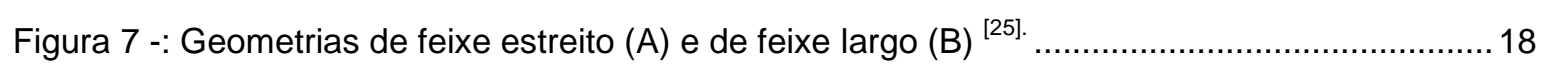

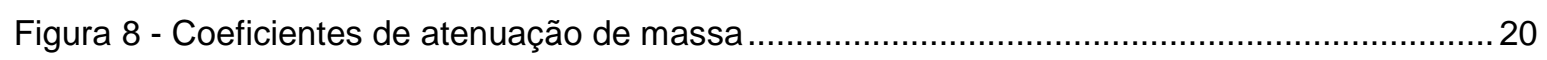

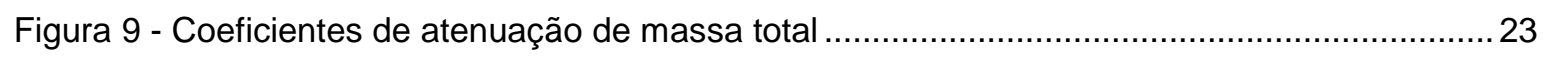

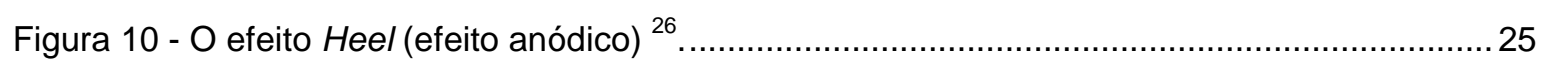

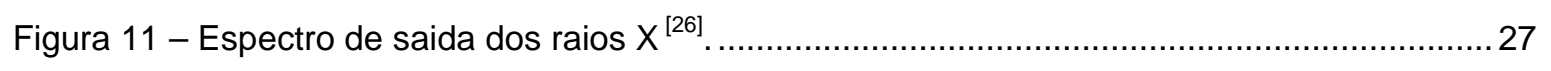

Figura 12 - Comparação de espectros gerados com diferentes formas de onda ............................29

Figura 13 - Imagem de um conjunto fonte de radiação $X$ [ .................................................... 31

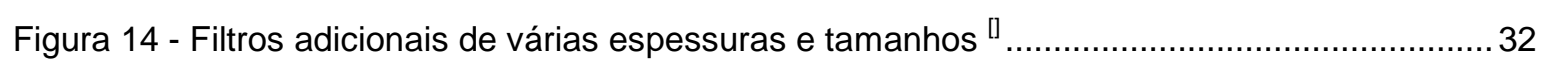

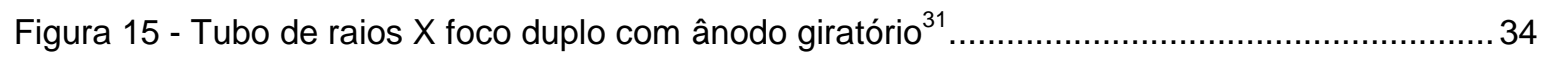

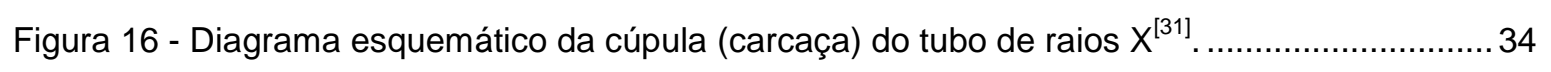

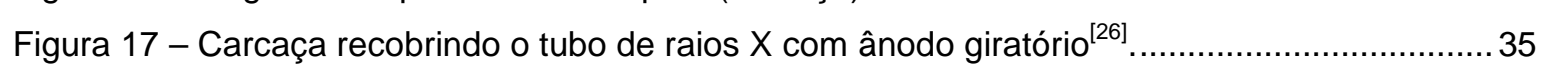

Figura 18 - Redução da radiação de fuga por meio da carcaça protetora ${ }^{[32]}$.................................. 35

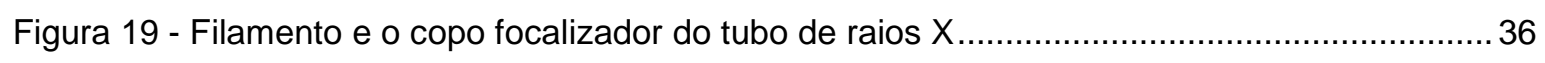

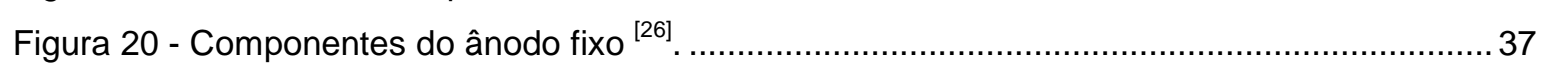

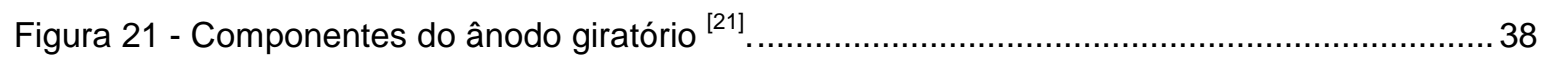

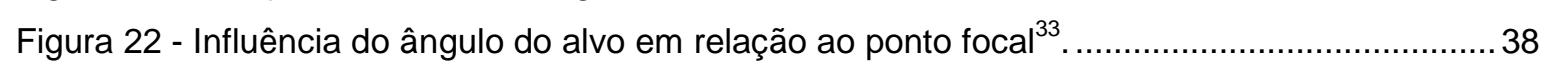

Figura 23 - Vistas lateral, frontal e abaixo do eixo central do Anodo-Catodo. ................................. 40

Figura 24 - Relação entre o ângulo do anodo e a cobertura do campo de radiação. ....................... 41

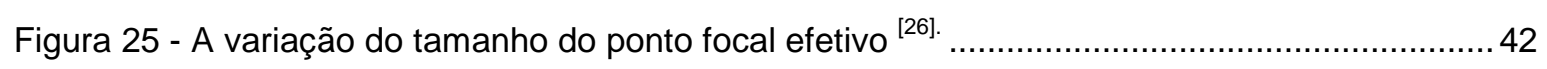

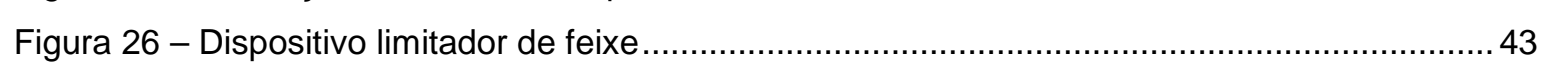

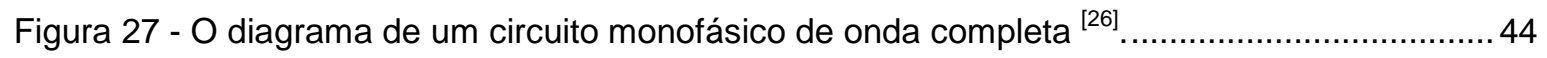

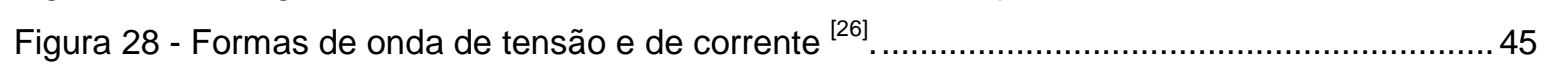

Figura 29 - Formas de onda do gerador de raios $X$ trifásico ...................................................... 46

Figura 30 - Circuito simplificado para gerador trifásico de seis pulsos ............................................47

Figura 31 - Forma de onda de saída do gerador com inversor de alta frequência ......................... 49

Figura 32 - Componentes modulares do gerador de alta freqüência............................................. 52

Figura 33- llustração da lei do inverso do quadrado da distância..................................................54

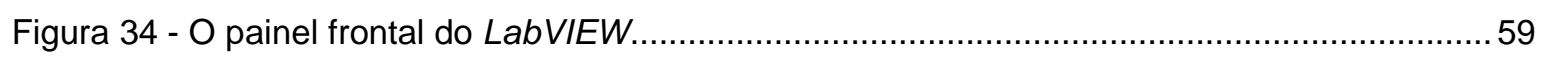

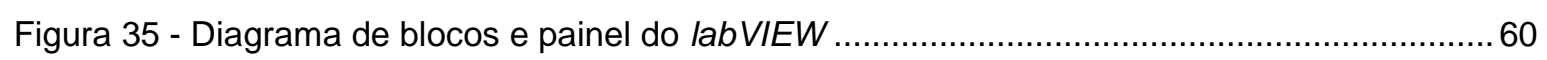




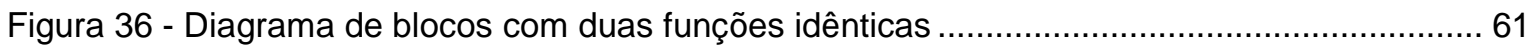

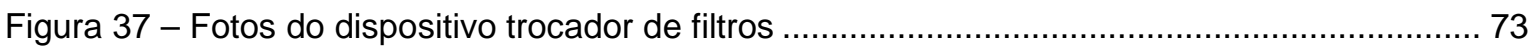

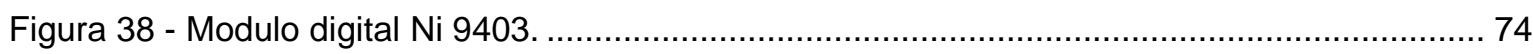

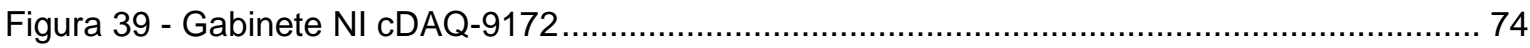

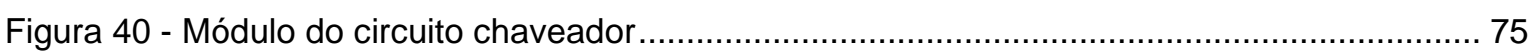

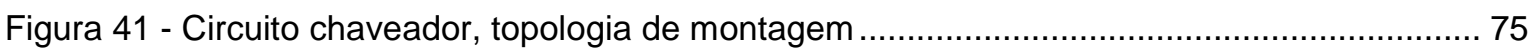

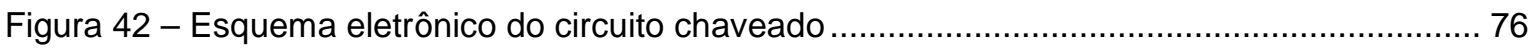

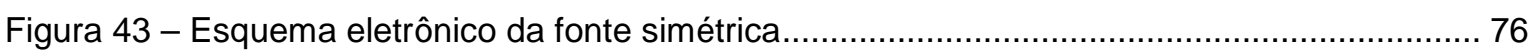

Figura 44 - montagem do circuito chaveador e fonte de alimentação .................................... 76

Figura 45 - Instalação do circuito chaveador na montagem do suporte dos drives de CD ............ 77

Figura 46 - Conexão do dispositivo trocador de filtros com a placa de controle ..........................77

Figura 47 - Dispositivo trocador de filtros instalado na estrutura mecânica ............................. 77

Figura 48 - Vistas frontal e traseira da montagem final do dispositivo de ensaio ....................... 78

Figura 49 - Painel de configuração da comunicação com o sistema de aquisição ...................... 79

Figura 50 - Painel do ensaio para a determinação da CSR ........................................... 80

Figura 51 - Mensagem de medição finalizada .......................................................... 81

Figura 52 - Painel do ensaio para a determinação da filtração com equivalência da qualidade em

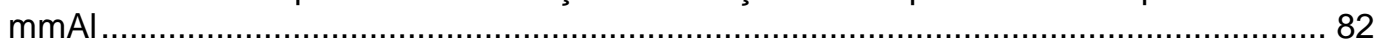

Figura 53 - Arranjo para o ensaio de determinação da CSR segundo a Norma IEC61267 ...........83

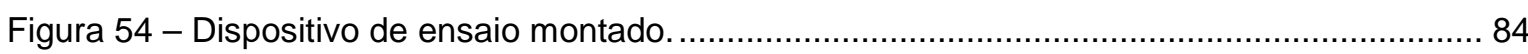

Figura 55 - Exemplo de materiais, mesa e bucky mural, interpostos entre o paciente e receptor de

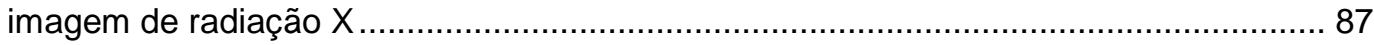

Figura 56 - Tela de entrada de erros do programa HVLCalc.jar ...................................... 94

Figura 57 - (A) Imagem do arranjo tradicional e (B) do dispositivo de ensaio desenvolvido para determinação da CSR

Figura 59 - (A) Imagem do arranjo tradicional e (B) do dispositivo de ensaio desenvolvido para determinação da filtração com equivalência de qualidade dos materiais .................... 102

Figura 60 - Codificação do dispositivo trocador de filtros ............................................ 104

Figura 61 - Posições OB e 3B no dispositivo trocador de filtros ........................................ 106

Figura 62 - Gráfico de comparação entre as posições e entre a pureza dos filtros ................... 107

Figura 63 - Gráfico das diferenças entre a posição dos filtros e entre purezas ........................ 108

Figura 63 - Espectro de Energia da radiação de referência IEC RQR2 com filtros de alta e baixa

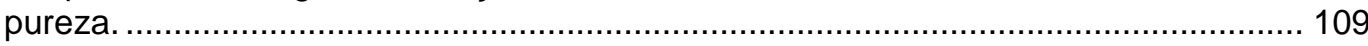

Figura 65 - Espectro de Energia da radiação de referência IEC RQR6 com filtros de alta e baixa pureza.

Figura 66 - Espectro de Energia da radiação de referência IEC RQR10 com filtros de alta e baixa

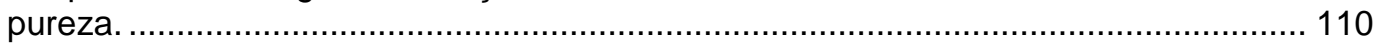

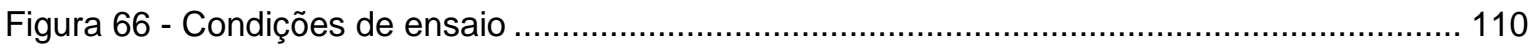

Figura 68 - Comparação entre os valores de kerma no ar para as condições de ensaio A, B, C e D

Figura 69 - Posição dos filtros agrupados, método tradicional ...................................... 113

Figura 70 - Posição dos filtros agrupados da maior para a menor espessura ......................... 114

Figura 71 - Posição dos filtros agrupados da menor para a maior espessura ........................... 115 
Figura 72 - Valores de CSR obtidos com o gerador de referência e o com o dispositivo

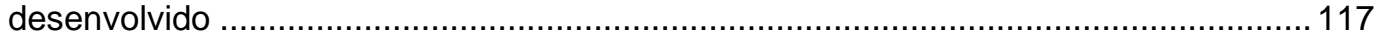

Figura 73 - Variação da tensão (kV) durante o período de testes. .................................................. 118

Figura 74 - Valores de tempo (ms) medidos durante o período de testes. .................................. 119

Figura 75 - Variação da corrente $(\mathrm{mA})$ durante o período de testes ............................................ 119

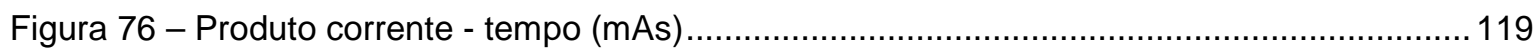




\section{ÍNDICE DE TABELAS}

Tabela 1 - Programa de avaliação da conformidade de Equipamentos Elétricos sob Regime de Vigilância Sanitária ".....

Tabela 2 - Comparação entre as cláusulas das versões de2001 e 2011 da norma ABNT NBR IEC 60601-1-3.

Tabela 3 - Lista de elementos e seus efeitos nos seres humanos

Tabela 4 - Especificações do medidor de parâmetros radiológicos modelo 9095 e da câmara de Ionização modelo 10x06-06

Tabela 5 - Especificações do Divisor de alta-tensão Dynalyzer IIIU ${ }^{\square}$............................................. 65

Tabela 6 - Especificações do Medidor de nível digital $(0$ a 360 $)$ e da Régua de precisão ${ }^{\square}$........... 66

Tabela 7 - Especificações dos Filtros de alumínio de alta pureza (99,9\% - tipo 1145) ${ }^{\square}$................. 67

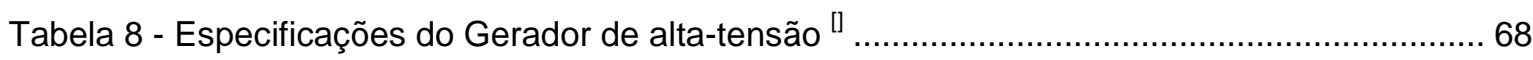

Tabela 9 - Especificações do Conjunto emissor de radiação $X$ do gerador de raios $X$ de referência 08

Tabela 10 - Especificações do Gerador de alta-tensão ${ }^{\square}$.......................................................... 70

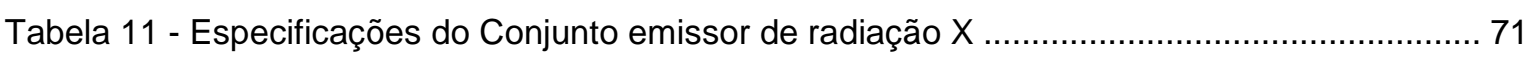

Tabela 12- Especificações do dispositivo limitador de feixe ${ }^{\square}$..................................................... 71

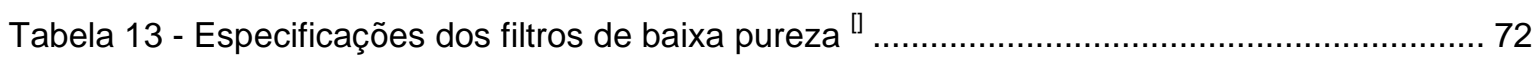

Tabela 14- Características do Gerador de raios X exigidas pelas normas ..................................... 91

Tabela 15 - Fontes de incerteza utilizadas no software HVLCalc.jar ........................................... 94

Tabela 16 - Comparação da metodologia sem o dispositivo desenvolvido e com o dispositivo

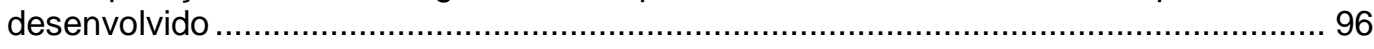

Tabela 17 - Comparação da metodologia sem o dispositivo desenvolvido e com o dispositivo

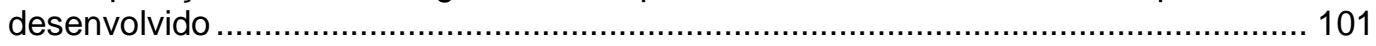

Tabela 18 - Codificação dos filtros de baixa e alta pureza utilizados ........................................... 104

Tabela 19 - Verificação entre a posição OB e 3B dos filtros de Baixa pureza ................................ 106

Tabela 20 - Verificação entre a posição OB e 3B dos filtros de Alta pureza................................... 106

Tabela 21 - Verificação da influência da pureza dos filtros nas posições OB através da comparação

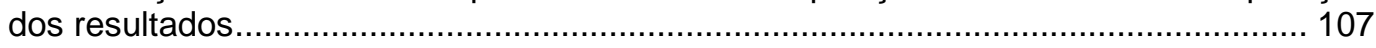

Tabela 22 - Verificação da influência da pureza dos filtros nas posições 3B através da comparação

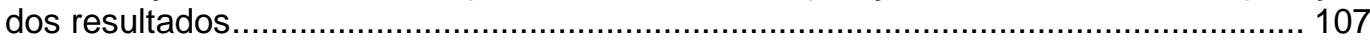

Tabela 23 - Parâmetros de raios $X$ para filtros de alta e baixa pureza $X$ para radiações de referencia RQR 2, RQR 6 e RQR $10 .$.

Tabela 24 - Verificação da influência do material que compõe o drive e o suporte do trocador de filtros (madeira) com relação à radiação espalhada..................................................... 111

Tabela 25 - CONDIÇÃO A - Filtros agrupados no primeiro drive, método tradicional. ................. 113

Tabela 26 - CONDIÇÃO B - Filtros de alta e baixa pureza dispostos da maior para a menor

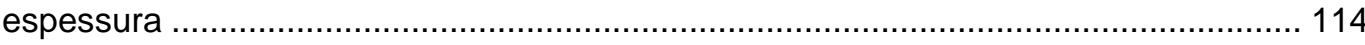

Tabela 27 - CONDIÇÃO C - Filtros de baixa e de alta pureza dispostos da menor para a maior espessura

Tabela 28 - Determinação da CSR com os filtros de alta pureza dispostos da menor para a maior espessura 
Tabela 29 - Comparação do método da norma IEC 60522: 1999 realizado pelo o dispositivo de

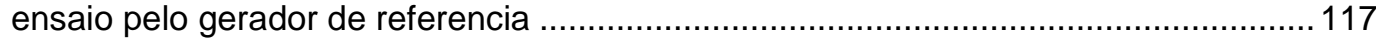

Tabela 30. Valores de exatidão das grandezas obtidas pelo conjunto formado pelo Divisor de Altatensão /Osciloscópio 


\section{INTRODUÇÃO}

\subsection{Processo de Certificação}

Diversos produtos, nacionais ou importados, que possam a representar um risco de segurança ao usuário devem ser avaliados quanto a sua segurança e desempenho.

No Brasil o INMETRO (Instituto Nacional de Metrologia e Qualidade Industrial) é o responsável pela gestão dos Programas de Avaliação da Conformidade, no âmbito do Sistema Brasileiro de Avaliação da Conformidade - SBAC.

O objetivo do INMETRO é implantar de forma assistida programas de avaliação da conformidade de produtos, processos, serviços e pessoal, alinhados às políticas do Sistema Nacional de Metrologia, Normalização e Qualidade Industrial (SINMETRO) e às práticas internacionais, promovendo competitividade, concorrência justa e proteção à saúde e segurança do cidadão e ao meio ambiente. Seu público-alvo são os setores produtivos, as autoridades regulamentadoras e os consumidores ${ }^{[3]}$.

Os programas de avaliação da conformidade possuem basicamente duas etapas, sendo estas, uma auditoria de fabrica, onde os requisitos referentes ao processo produtivo são avaliados e o ensaio de tipo do equipamento objeto da certificação.

$\mathrm{Na}$ avaliação do processo produtivo as fabricas são avaliadas quanto aos requisitos da ISO 9001: $2008{ }^{[4]}$ e com relação aos requisitos completares estabelecidos pelas portarias publicadas pelo INMETRO, específicas de cada produto.

Nos ensaios chamados de "tipo" os equipamentos são avaliados através de ensaios (testes) estabelecidos por normas nacionais e internacionais, tais ensaios avaliam a segurança e o desempenho dos produtos. Os ensaios são realizados por laboratórios acreditados pelo INMETRO, onde, é gerado no final dos ensaios um relatório técnico contemplando todos os ensaios relativos à segurança do equipamento ensaiado. A Figura 1 apresenta os passos de um processo de certificação típico. 


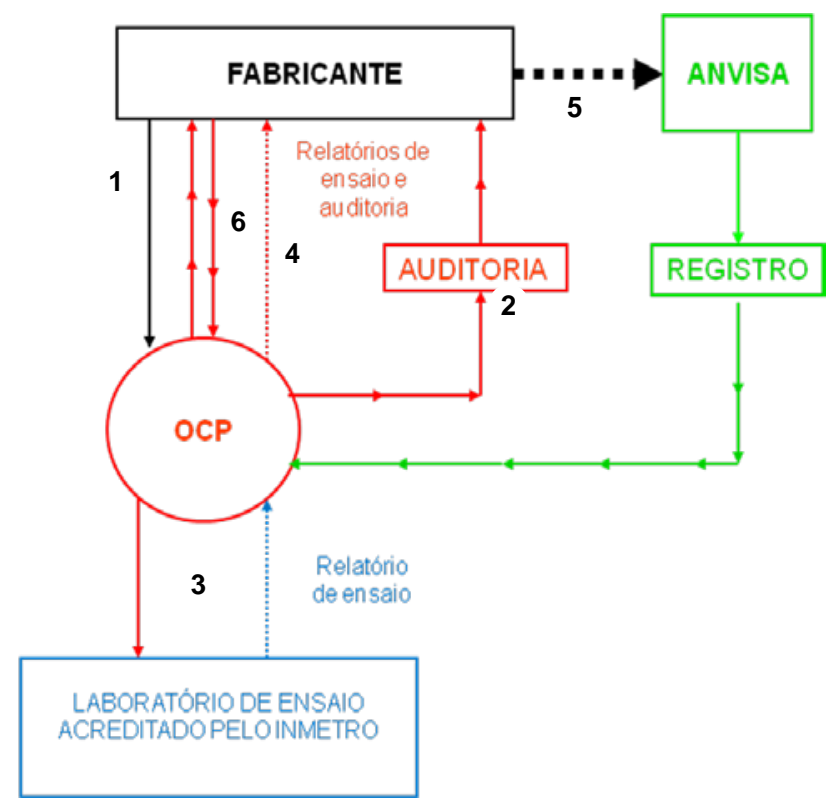

$1^{\circ}$ Passo o fabricante contrata uma Certificadora de produto (Organismo de Certificação de Produto OCP);

$\mathbf{2}^{\circ}$ Passo o OCP realiza auditoria na empresa e CONTRATA um laboratório ACREDITADO;

$3^{\circ}$ Passo o laboratório executa os ensaios no corpo de prova coletado pelo OCP, e ao término destes encaminha o relatório final ao OCP:

$4^{\circ}$ Passo não havendo não conformidades tanto nos ensaios no equipamento como na auditoria de fabrica, o OCP encaminha a documentação para o fabricante do eletromédico

$5^{\circ}$ Passo, com a documentação necessária o fabricante solicita a ANVISA o registro do produto;

$6^{\circ}$ passo o registro concedido pela ANVISA será monitorado pelo OCP enquanto o equipamento eletromédico existir no mercado;

Figura 1 - Passos do processo de certificação

Este trabalho está diretamente relacionado ao programa de avaliação da conformidade de "Equipamentos Elétricos sob Regime de Vigilância Sanitária" que é um programa de certificação compulsória, portaria $350^{[5]}$, onde todos os fabricantes de tais equipamentos, que se enquadrarem no campo de aplicação da portaria - Tabela 1, devem certificar seus produtos para obter o registro dos mesmos junto a ANVISA (Agência Nacional de Vigilância Sanitária) para que possam produzi-los e comercializá-los, os que são dispensados desse processo passam apenas por um processo de fiscalização de Boas Práticas de Fabricação (BPF). Sendo atestada a conformidade, segue-se o pedido de obtenção de registro do produto junto à ANVISA ${ }^{[6]}$. 
Tabela 1 - Programa de avaliação da conformidade de Equipamentos Elétricos sob Regime de Vigilância Sanitária ${ }^{[7]}$

\begin{tabular}{|c|c|c|c|c|c|c|}
\hline PROGRAMA & $\begin{array}{c}\text { ORGÃO } \\
\text { REGULAMENTADOR }\end{array}$ & DOCUMENTO LEGAL & DATA DOU & $\begin{array}{l}\text { ORGÃO } \\
\text { FISCAL }\end{array}$ & $\begin{array}{l}\text { REGRA ESPECIFICA - RE OU } \\
\text { REGULAMENTO (OU REQUISITOS) } \\
\text { DE AVALIAÇÃO DA } \\
\text { CONFORMIDADE - RAC }\end{array}$ & $\begin{array}{l}\text { DOCUMENTO NORMATIVO - } \\
\text { NBR OU REGULAMENTO } \\
\text { TÉCNICO DA QUALIDADE - RTQ }\end{array}$ \\
\hline $\begin{array}{l}\text { Equipamentos } \\
\text { Elétricos sob Regime } \\
\text { de Vigilância Sanitária }\end{array}$ & Anvisa & $\begin{array}{l}\text { Resolução Anvisa RDC } n^{\circ} 27 \text { de junho } \\
\text { de 2011, Portaria Interministerial MS/ } \\
\text { MDIC } n^{\circ} 692 \text { de 08/04/09 e Instrução } \\
\text { Normativa - IN da Anvisa, vigente }\end{array}$ & $\begin{array}{c}\text { 13/12/94, } \\
01 / 09 / 99 \\
31 / 08 / 99 \\
26 / 10 / 01 \text { e } \\
08 / 11 / 01\end{array}$ & $\begin{array}{l}\text { Anvisa - } \\
\text { RBMLQ }\end{array}$ & $\begin{array}{l}\text { RAC anexo à Portaria Inmetro } n^{\circ} 350 \\
\text { de 06/09/2010 }\end{array}$ & $\begin{array}{l}\text { NBR IEC } 60601-1 \text {, } \\
\text { NBR IEC } 60601-2 \text { e NBR ISO } \\
\text { 13485:2004 }\end{array}$ \\
\hline
\end{tabular}


A norma ABNT NBR IEC 60601-1-3 é uma colateral aplicável aos equipamentos de raios $X$ e a sub-conjuntos de tais equipamentos, nos quais imagens radiológicas de um paciente humano são utilizadas para efetuar diagnósticos, fazer planejamentos ou orientação para procedimentos médicos.

O objetivo da norma colateral ABNT NBR IEC 60601-1-3 é estabelecer as prescrições gerais para proteção contra radiação $X$ em equipamentos de raios $X$, de forma que a irradiação em um paciente humano, 0 operador, os funcionários e o público em geral possa ser mantida nos níveis tão baixa quanto razoavelmente exequível, sem prejuízo aos benefícios do procedimento radiológico.

As normas particulares podem especificar os valores e/ou medidas apropriados para as prescrições gerais especificadas na norma colateral ABNT NBR IEC 60601-1-3.

A norma colateral ABNT NBR IEC 60601-1-3 considera os aspectos da proteção contra radiação relativos à radiação $X$ apenas.

Prescrições para o controle da energia elétrica utilizada para gerar a radiação $X$, que também é um aspecto importante da proteção contra radiação, estão incluídas na IEC 60601-1 e nas normas particulares para a segurança e desempenho essencial do equipamento em questão.

$\mathrm{Na}$ figura 2 é apresentado como as normas são aplicadas em equipamento de raios $X$ convencional. 
- NORMA GERAL - ABNT NBR IEC 60601-1 - Aplicável a todos os equipamentos definidos como eletromédicos

- NORMA COLATERAL - ABNT NBR IEC 60601-1-X - Aplicável a grupos de equipamentos específicos

- NORMA PARTICULAR - ABNT NBR IEC 60601-2-X - Aplicável a um tipo de equipamento específico

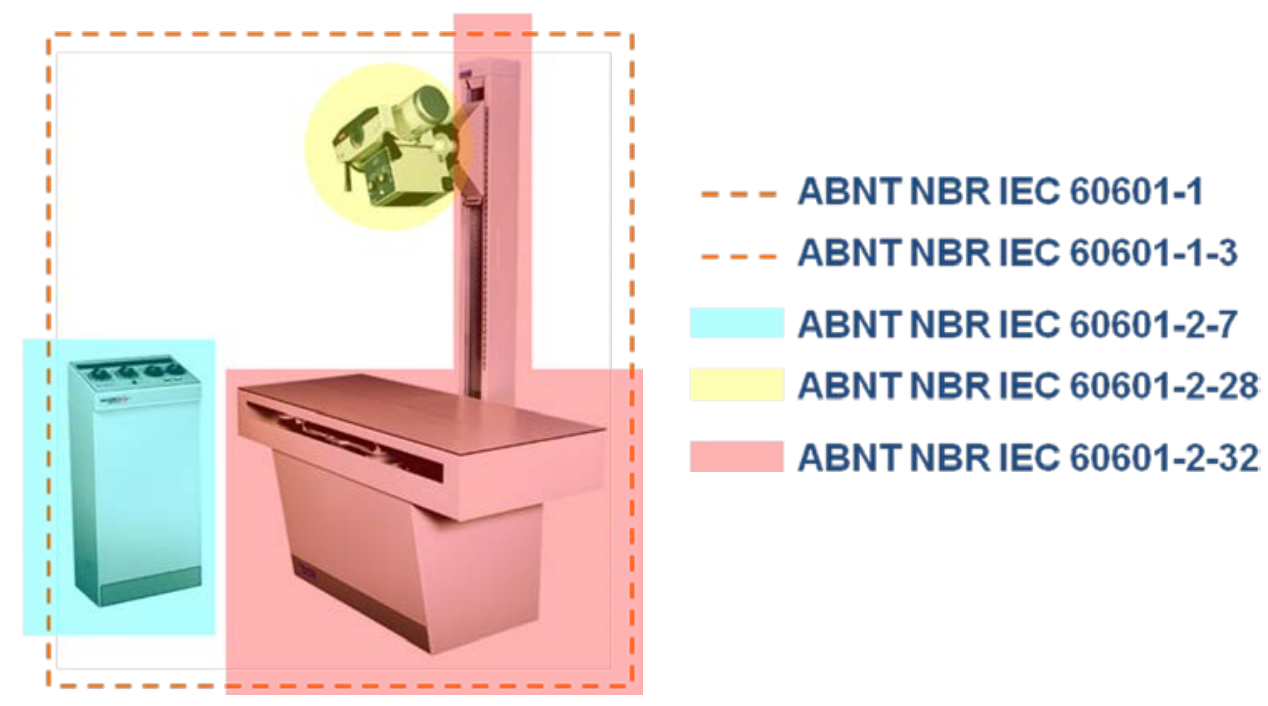

Figura 2 - Aplicação das normas em um equipamento de raios $X$ convencional

A norma geral ABNT NBR IEC 60601-1 contém prescrições gerais de segurança que englobam todos os equipamentos elétricos sob regime de vigilância sanitária.

A norma colateral ABNT NBR IEC 60601-1-3 contém, como já descrito anteriormente, prescrições de segurança contra a radiação ionizante.

A norma ABNT NBR IEC 60601-2-7 [8] contém prescrições particulares de segurança para geradores de raios $X$ para diagnóstico médico formado pelo gerador de alta-tensão e pelo seu sistema de controle.

A norma ABNT NBR IEC 60601-2-28 [9] contém prescrições particulares de segurança para o Conjunto fonte e conjunto emissor de radiação $X$, cúpula com o tubo de raios $X$ inserido e o sistema de colimação. 
A norma ABNT NBR IEC 60601-2-32 [10] contém prescrições particulares de segurança para os dispositivos associados aos equipamentos de raios $X$, por exemplo, mesa radiológica utilizada para o suporte do paciente e como suporte do chassi radiográfico, bucky mural utilizado para o apoio do paciente e como suporte do chassi radiográfico.

Frente ao exposto conclui-se que a certificação compulsória é uma das ocorrências mais importantes no cenário das tecnologias em saúde devido à sua repercussão no setor industrial e para a sociedade através dos benefícios gerados em termos de segurança e qualidade de tais equipamentos.

\subsection{O dispositivo de ensaio desenvolvido}

A norma utilizada para a concepção do dispositivo de ensaio, objeto deste trabalho, foi a ABNT NBR IEC 60601-1-3 versões 2001 e 2011. A existência atípica de uma norma publicada com duas versões se deve ao fato

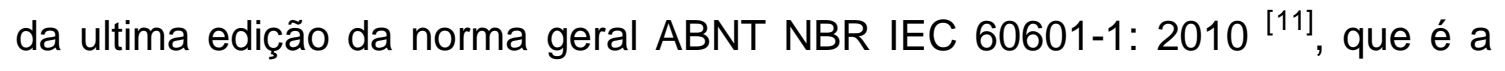
norma geral aplicada a todos os equipamentos eletromédicos e complementada pela norma ABNT NBR IEC 60601-1-3, não ser aplicada nos ensaios ainda, pois é necessário um tempo de espera até que todas as normas da serie IEC 60601-1-X e IEC 60601-2-X sejam traduzidas e adequadas ao novo formato imposto por esta nova edição da norma geral.

Na Tabela 2 é realizada uma comparação entre as cláusulas envolvidas com o dispositivo de ensaio das normas nas versões de 2001 e 2011. 
Tabela 2 - Comparação entre as cláusulas das versões de2001 e 2011 da norma ABNT NBR IEC 60601-1-3

\begin{tabular}{|c|c|c|}
\hline ABNT NBR IEC 60601-1-3: 2001 & ABNT NBR IEC 60601-1-3: 2011 & Diferenças entre as versões de 2001 e 2011 \\
\hline Cláusulas & Cláusulas & \\
\hline $\begin{array}{l}29.201 .3 \text { - Filtração no conjunto-emissor } \\
\text { de radiação x; }\end{array}$ & $\begin{array}{l}7.1 \text { - camadas semirredutoras e filtração } \\
\text { total em equipamentos de raios } X\end{array}$ & \multirow[t]{3}{*}{$\begin{array}{l}\text { A conformidade é verificada através dos ensaios descritos } \\
\text { em } 7.4,7.5 \text { e } 7.6 \text { e inspeções. }\end{array}$} \\
\hline $\begin{array}{l}29.201 .4 \text { - Filtração no conjunto-fonte de } \\
\text { radiação x; }\end{array}$ & $\begin{array}{l}7.1 \text { - camadas semirredutoras e filtração } \\
\text { total em equipamentos de raios } X\end{array}$ & \\
\hline $\begin{array}{l}\text { 29.201.5 }- \text { Filtração } \\
\text { equipamento de raios } x ;\end{array}$ & $\begin{array}{l}7.1 \text { - camadas semirredutoras e filtração } \\
\text { total em equipamentos de raios } X\end{array}$ & \\
\hline $\begin{array}{l}\text { 29.201.6 - Indicação das propriedades } \\
\text { do filtro; }\end{array}$ & 7.3 - Indicação das propriedades do filtro & $\begin{array}{l}\text { A conformidade é verificada através de inspeção dos } \\
\text { conjuntos-emissores de radiação } X \text {, dos materiais de } \\
\text { filtração e dos filtros adicionais e através do exame dos } \\
\text { documentos acompanhantes. }\end{array}$ \\
\hline $\begin{array}{l}\mathbf{2 9 . 2 0 1 . 7 ~ - ~ E n s a i o ~ p a r a ~ f i l t r a c ̧ a ̃ o ~ p o r ~} \\
\text { materiais irremovíveis; }\end{array}$ & $\begin{array}{l}7.4 \text {-Ensaio para filtração por materiais } \\
\text { não removíveis }\end{array}$ & $\begin{array}{l}\text { A filtração com equivalência de qualidade é determinada de } \\
\text { acordo com a IEC 60522: } 1999 \text {. }\end{array}$ \\
\hline $\begin{array}{l}\mathbf{2 9 . 2 0 1 . 8} \text { - Ensaio para filtros adicionais } \\
\text { e materiais (que interceptam o feixe de } \\
\text { raiação } x \text { ); }\end{array}$ & $\begin{array}{l}7.5 \text { - Ensaio para filtros adicionais } \mathrm{e} \\
\text { materiais }\end{array}$ & $\begin{array}{l}\text { Para a medição é utilizado um feixe de raios } X \text { com a mesma } \\
\text { tensão do tubo de raios } X \text { utilizada para determinar a } \\
\text { filtração por materiais irremovíveis e a primeira camada } \\
\text { semirredutora. }\end{array}$ \\
\hline $\begin{array}{l}\mathbf{2 9 . 2 0 1 . 9 -} \text { Ensaio para camada } \\
\text { semirredutora }\end{array}$ & 7.6 - Ensaio para camada semirredutora & $\begin{array}{l}\text { Alteração dos limites da primeira camada semirredutora } \\
\text { permissível } \\
\text { Tabelas } 204 \text { e } 3 \text { nas versões } 2001 \text { e } 2008 \text { respectivamente }\end{array}$ \\
\hline $\begin{array}{l}29.206 \text { - Atenuação do feixe de radiação } \\
\text { x }\end{array}$ & $\begin{array}{l}10 \text { - Atenuação do feixe de raios } X \text { entre o } \\
\text { paciente e o receptor da imagem por } \\
\text { raios } X\end{array}$ & $\begin{array}{l}\text { A conformidade é verificada através do exame do arquivo } \\
\text { de gerenciamento de risco. }\end{array}$ \\
\hline
\end{tabular}




\subsubsection{Critérios para o desenvolvimento de um dispositivo de ensaio}

Para o desenvolvimento do dispositivo de ensaio foi necessário estabelecer critérios para que os objetivos deste trabalho fossem alcançados. Os critérios abaixo relacionados foram determinados em função do funcionamento esperado do dispositivo e do impacto que produziria em termos da sua utilização, ao atendimento dos requisitos normativos e a questão ambiental.

- Cumprir os com os requisitos da ABNT NBR IEC 60601-1-3: e com a norma IEC 60522: $1999^{\text {[12]; }}$

- Cumprir os com os requisitos da ABNT NBR ISO IEC 17025: 2005

- Segurança, otimização e incerteza de medição

- Questão ambiental - reciclagem de componentes (Drives de CD) 


\section{OBJETIVOS}

O objetivo deste trabalho é o desenvolvimento de um dispositivo de ensaio para determinação da CSR e da filtração com equivalência de qualidade dos materiais que interceptam o feixe de radiação $X$ de geradores para diagnóstico médico, referenciado à norma ABNT NBR IEC 60601-1-3: versões 2001 (em vigor) e 2011 (que entrará em vigor em 2014).

O dispositivo de ensaio foi ser desenvolvido, caracterizado e validado para realizar os ensaios estabelecidos na sub-cláusula 29.201 da norma colateral ABNT NBR IEC 60601-1-3: 2001, sendo estes:

- 29.201.3 Filtração no CONJUNTO-EMISSOR de radiação X;

- 29.201.4 Filtração no CONJUNTO-FONTE de radiação X;

- 29.201.5 Filtração TOTAL NO EQUIPAMENTO DE RAIOS X;

- 29.201.6 Indicação das propriedades do FILTRO;

- 29.201.7 Ensaio para FILTRAÇÃO por materiais irremovíveis;

- 29.201.8 Ensaio para FILTROS ADICIONAIS e materiais que interceptam o FEIXE DE RADIAÇÃO X);

As características relacionadas a seguir foram ser incorporadas desde a concepção, projeto e desenvolvimento até a conclusão do dispositivo.

- Manuseio simples;

- Setup fixo, sem a necessidade de montagem e ajustes;

- Sistema automatizado de seleção de filtros e determinação da CSR;

- Baixo Custo;

- Sistema de aquisição de dados, e

- Confiabilidade metrológica 


\section{FUNDAMENTOS}

A fundamentação teórica deste trabalho se inicia na produção dos feixes de raios $X$ e se estende até as questões referentes à proteção radiológica presentes na execução dos ensaios realizados pelo dispositivo desenvolvido. Para definir os tópicos foram levados em consideração os temas relevantes necessários para o entendimento do dispositivo de ensaio desenvolvido, principalmente com relação à filtração do feixe de raios $X$ e a geração do feixe de raios $X$.

\subsection{Histórico dos Raios X}

Os raios $\mathrm{X}$, foram descobertos pelo Professor Dr. Wilhelm Conrad Roentgen (1845-1923), em 8 de novembro de 1895. O seu descobrimento baseou-se em experiências com ampolas de Hittorf (físico alemão, 1824-1914) e Crookes (físico e químico inglês, 1832-1919). Quando os elétrons acelerados chocam-se com um objeto metálico, produzem raios $X$. A energia cinética dos elétrons se transforma em energia eletromagnética e a radiação é criada pela conversão da energia desses elétrons em fótons com energias apropriadas.

Roentgen fez uma série de observações acerca dos raios $X$ e concluiu que:

- causam fluorescência em certos sais metálicos;

- enegrecem placas fotográficas;

- são radiações do tipo eletromagnética, pois não sofrem desvio em campos elétricos ou magnéticos;

- são diferentes dos raios catódicos;

- tornam-se "duros" (mais penetrantes) após passarem por filtros;

- produzem radiações secundárias em todos os corpos que atravessam;

- $\quad$ propagam-se em linha reta (do ponto focal) para todas as direções;

- transformam gases em condutores elétricos(ionização); 
O choque do feixe de elétrons que saem do cátodo, com o ânodo (alvo) produz dois tipos de raios X. A radiação de freamento (Bremsstrahlung) e a radiação característica ${ }^{[13]}$.

\subsection{Grandezas Dosimétricas}

Os efeitos da radiação na matéria dependem de fatores como tipo da radiação e das interações da radiação com a matéria. As grandezas dosimétricas correlacionam as medidas físicas com os efeitos reais ou efetivos e são, em essência, produtos de grandezas radiométricas e coeficientes de interação.

As grandezas dosimétricas apresentadas a seguir estão descritas no relatório da ICRU Report $60^{[14]}$.

\subsubsection{Kerma (K)}

A grandeza kerma (kinetic energy released per unit mass) é o quociente de dEtr por dm, onde dEtr é a soma da energia cinética inicial de todas as partículas carregadas liberadas por partículas não carregadas em uma massa dm de material, como mostra a equação [1]. A unidade do kerma é J.kg-1 e o nome especial para esta unidade é gray (Gy). É necessário definir o meio para a expressão do valor de kerma, normalmente o ar ou a água.

$$
K=\frac{d E_{t r}}{d m}
$$

A taxa de kerma, $\dot{K}$, é o quociente de $\mathrm{dK}$ por $\mathrm{dt}$, onde $\mathrm{dK}$ é o incremento do kerma no intervalo de tempo dt, como mostra a equação [2]. A unidade da taxa de kerma é J.kg-1. $\mathrm{s}^{-1}$ e se o nome especial gray está sendo utilizado, a unidade é gray por segundo $\left(G y . s^{-1}\right)$.

$$
\dot{K}=\frac{d K}{d t}
$$




\subsubsection{Exposição $(\mathrm{X})$}

A grandeza exposição é o quociente de dQ por dm, onde dQ é o valor absoluto da carga total de íons de um sinal produzido no ar quando todos os elétrons e pósitrons liberados ou criados pelos fótons no ar de massa dm são completamente freados no ar, como mostra a equação [3]. A unidade da grandeza exposição é o C. $\mathrm{kg}^{-1}$.

$$
X=\frac{d Q}{d m}
$$

A taxa de exposição, $\dot{X}$, é o quociente de $d X$ por $d$, onde $d X$ é o incremento da exposição no intervalo de tempo dt, como mostra a equação [4]. A unidade da taxa de exposição é $\mathrm{C} \cdot \mathrm{kg}^{-1} \cdot \mathrm{s}^{-1}$.

$$
\dot{X}=\frac{d X}{d t}
$$

\subsubsection{Dose Absorvida (D)}

A grandeza dose absorvida é o quociente de $d \bar{\varepsilon}$ por $\mathrm{dm}$, onde $d \bar{\varepsilon}$ é a energia média depositada na matéria de massa dm, como mostra a equação [5]. A unidade desta grandeza é J. $\mathrm{kg}^{-1}$ e o nome especial para a unidade de dose absorvida é o gray (Gy).

$$
D=\frac{d \bar{\varepsilon}}{d m}
$$

A taxa de dose absorvida, $\dot{D}$, é o quociente de $\mathrm{dD}$ por dt, onde dD é o incremento da dose absorvida no intervalo de tempo dt, como mostra a equação [6]. A unidade para a taxa de dose absorvida é o $\mathrm{J} \cdot \mathrm{kg}^{-1} \cdot \mathrm{s}^{-1}$. Quando for utilizado o nome especial para unidade, gray, a unidade da taxa de dose absorvida é gray por segundo $\left(G y \cdot s^{-1}\right)$.

$$
\dot{D}=\frac{d D}{d t}
$$




\subsection{Radiaçãode Freamento (Bremsstrahlung)}

A radiação de freamento é responsável pelo maior número de fótons de radiação $X$. Nesse processo, os elétrons ao penetrarem no material alvo são atraídos pelo núcleo dos átomos do mesmo sofrendo um desvio de sua trajetória inicial. Com isso, o elétron perde parte de sua energia cinética que resulta em fótons de energia variada ${ }^{[15,16]}$.

A energia perdida pelo elétron durante esta interação aparece como um fóton de raios $X$ com frequência $v$ e energia $h v$. Em algumas colisões mais raras, pode ocorrer o completo freamento do elétron, dando origem a um fóton de energia $h v$ igual à energia inicial do elétron. A Figura 3 mostra a interação (colisão) entre elétron de energia E1 e núcleo do átomo do alvo dando origem a um fóton de energia $h v$ (fóton de raios $\mathrm{X}$ ) pelo processo de Bremsstrahlung.

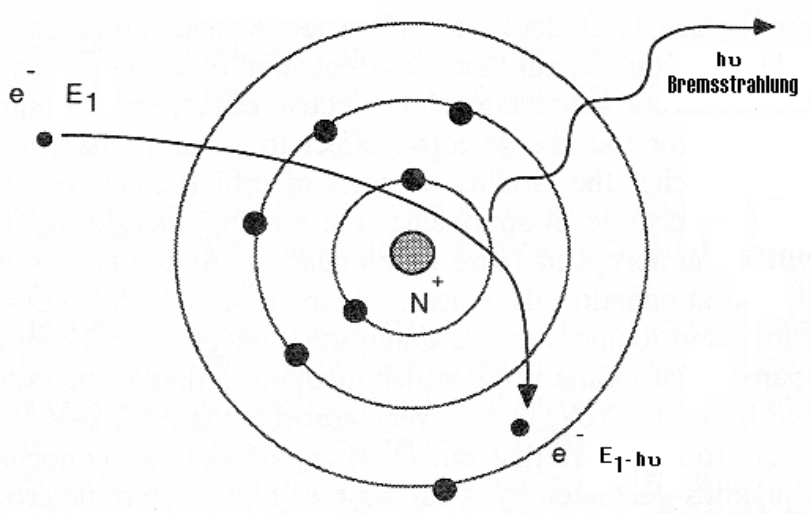

Figura 3. Colisão entre elétron de energia $E_{1}$ e núcleo do átomo do alvo ${ }^{[15] .}$

O espectro de Bremsstrahlung é composto em maior parte por fóton de baixa energia e este número é reduzido à medida que a energia aumenta, até a energia máxima, que corresponde à energia dos elétrons acelerados ${ }^{[17]}$.

$O$ espectro emergente do alvo e o espectro filtrado apresentam-se dentro da energia inicial dos elétrons, picos superpostos da radiação característica, conforme ilustrado na Figura 4 (linha tracejada) ${ }^{[15]}$. 


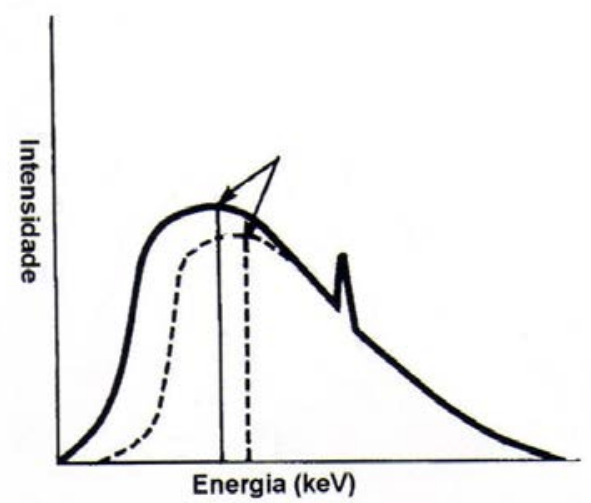

Figura 4 - Espectros de raios X produzidos para aplicação diagnóstica ${ }^{[15]}$.

\subsection{Radiação característica}

O processo de interação, Figura $\mathbf{5}$, que produz a radiação característica envolve a colisão de elétrons em alta velocidade com elétrons orbitais dos átomos do alvo. A interação pode ocorrer somente quando os elétrons incidentes possuem energia cinética maior que a energia de ligação dos elétrons dos átomos do alvo. Nestas condições o elétron orbital é ejetado do átomo deixando uma vacância (1) que é preenchida por um elétron de uma camada de maior energia. Nesta transferência de uma camada de maior energia para uma de menor energia, a energia perdida pelo elétron é emitida na forma de um fóton de raios $X$ (2), na sequencia o átomo restabelece seu equilíbrio (3) ${ }^{[18]}$.

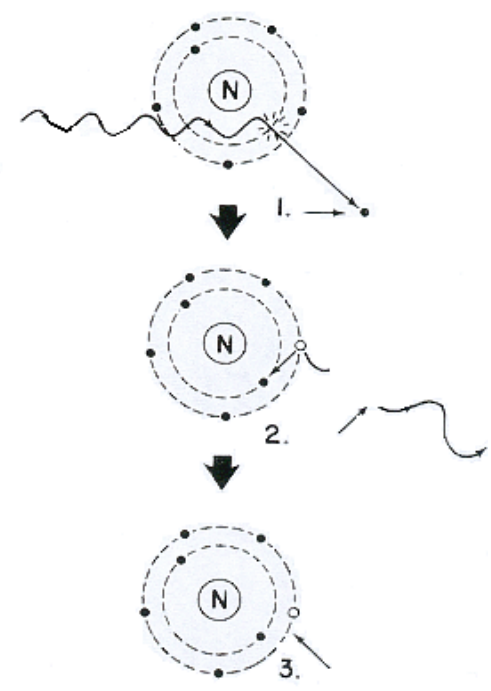

Figura 5 -. O processo de interação para a produção da radiação característica 
A energia do fóton de raios $\mathrm{X}$ emitido neste processo é característica do elemento químico pertencente ao material do alvo, o que dá o nome radiação característica. Um determinado material alvo pode promover uma série de energias de radiação características, dependendo do nível de energia em que as interações são originadas (camadas K,L,M, etc). Na Figura 6, os eventos 1,2 e 3 descrevem os elétrons incidentes interagindo nas proximidades do núcleo-alvo, resultando na produção de Bremsstrahlung, causado pela desaceleração e mudança de momento, com a emissão de um espectro contínuo de energia de fótons de raios $\mathrm{X}$.

O evento 4 demonstra a emissão de radiação característica, onde um elétron incidente com energia maior do que a energia de ligação da camada $\mathrm{K}$ colide e expele o elétron interior criando uma vaga instável.

Uma camada externa de elétrons em transição para a camada interior-interior emite um fóton raio $X$ com energia igual à diferença das energias de ligação do elétron da camada exterior e da camada $K$ que são as energias "características" do tungstênio ${ }^{[19]}$.

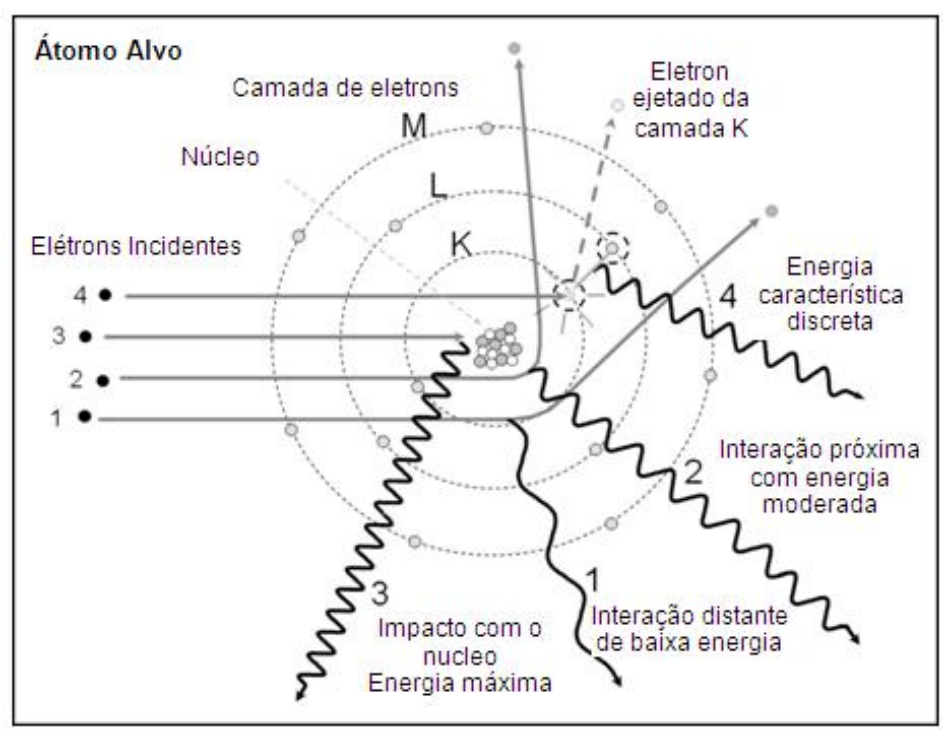

Figura 6 -. Produção de raios $X$ por conversão de energia 


\subsection{Qualidade de feixes de radiação}

A qualidade da radiação é o parâmetro principal a ser determinado pelo dispositivo de ensaio desenvolvido, pois esta relacionada diretamente aos requisitos dos ensaios definidos na ABNT NBR IEC 60601-1-3.

Quando o termo "qualidade" passou a ser aplicado a um feixe de radiação $X$, ele era usado como sinônimo de "dureza", ou seja, relativo à capacidade de penetração do feixe. A dureza do feixe era o principal parâmetro utilizado nos primórdios da radioterapia, quando a efetividade do tratamento de tumores com radiação $X$ dependia principalmente da capacidade de penetração do feixe e da limitação da dose liberada a tecidos saudáveis circunvizinhos. Este termo ainda é usado, com o mesmo significado, mesmo em aplicações onde o poder de penetração do feixe não precisa ser maximizado, como por exemplo, no caso do radiodiagnóstico. O termo qualidade da radiação também tem sido usado no sentido mais geral de distribuição espectral da energia de um feixe. Desta forma, a qualidade de um feixe de radiação $X$ pode ser especificada em termos de seu espectro ou de suas características de atenuação em um material de referência.

\subsubsection{A Camada Semirredutora (CSR)}

Um conceito mais usual para descrever e medir a qualidade do feixe é a camada semirredutora (CSR). A CSR é a espessura de um material especificado que atenua sob condições de feixe estreito, a radiação $x$ ou radiação gama, com uma determinada energia de radiação ou com um espectro particular, com intensidade tal que a taxa de kerma, ou a taxa de exposição ou a taxa de dose absorvida será reduzida à metade do valor que seria medido sem a presença desse material. A CSR é expressa em submúltiplos adequados do metro, juntamente com o material atenuador.

O material utilizado para os filtros em radiologia diagnóstica convencional é o alumínio e cobre e Molibdênio para mamografia e tomografia computadorizada. Um feixe de baixa energia será bastante reduzido por uma pequena filtração tendo, portanto baixa CSR. 
Sabe-se que a CSR não apresenta um valor constante para um dado feixe, mas aumenta com a filtração. Logo, a segunda CSR será maior que a primeira. Somente um feixe monoenergético terá sucessivas CSR's iguais.

A qualidade de radiação pode ser expressa, através de aproximações práticas, em termos de valores variáveis tais como:

- Alta-tensão com sua ondulação percentual e a filtração total;

- Primeira CSR, para a alta-tensão especificada com sua ondulação percentual;

- Primeira CSR e a filtração total;

- Coeficiente de homogeneidade $(\mathrm{CH})$, quociente entre a primeira e a segunda CSR's;

Para que se atenda a essa definição, os valores de taxa de kerma no ar não devem incluir os fótons espalhados, mas somente os fótons inicialmente presentes no feixe $\mathrm{e}^{[20]}$.

Embora a CSR forneça somente uma descrição da qualidade de radiação que é adequada para a maioria das situações clínicas, o valor de um segundo parâmetro (por exemplo, a diferença da tensão (kVp) do tubo de raios $X$ ou o coeficiente de homogeneidade do feixe de raios $X$ ) às vezes é indicado juntamente com a CSR.

Para a medição de CSR, devem ser utilizadas câmaras de ionização com pequena dependência energética, visto que o acréscimo de filtros para a diminuição da intensidade do feixe altera o espectro da radiação, aumentando a energia do feixe. Se a câmara de ionização utilizada apresentar uma grande dependência energética, o decréscimo no valor apresentado pela câmara de ionização não corresponderá diretamente à diminuição da intensidade do feixe $^{[21]}$.

A determinação da CSR exige filtros de alumínio de alta pureza, principalmente em feixes de baixa energia, porque o efeito fotoelétrico é predominante nessa faixa de energia. Assim, mesmo uma pequena quantidade de impureza de elevado número atômico nos filtros de alumínio irá levar a resultados incorretos ${ }^{[21]}$ e outro fator importante é que a CSR é expressa em termos do material utilizado para a sua determinação. 
Neste trabalho, as leituras efetuadas com a câmara de ionização foram da grandeza kerma no ar, devido à instrumentação utilizada. O procedimento para determinação da CSR consiste basicamente na leitura de kerma no ar inicial sem interposição de materiais absorvedores $\left(I_{0}\right)$ com 0 objetivo de se inferir no kerma no ar referentes à $1 / 2\left(I_{0} / 2\right)$ e $1 / 4\left(I_{0} / 4\right)$ do kerma no ar inicial, respectivamente. Posteriormente são interpostos filtros ao feixe de raios $X$ para que se possa estabelecer a curva do kerma no ar por espessura de material absorvedor para determinação da CSR.

As medições de CSR devem ser feitas sempre com geometria de feixe estreito. A geometria de feixe estreito garante que apenas os fótons primários que tenham sido transmitidos pelo atenuador entrem na câmara de ionização.

A geometria de feixe estreito refere-se a uma configuração experimental que é concebida para excluir fótons espalhados para que estes não sejam medidos pelo detector, como mostra a Figura $7 \mathbf{A}$.

Em geometria de feixe largo, o feixe possui uma largura tal que uma fração substancial de fótons espalhados permanece no feixe e estes fótons espalhados alcançam o detector, como mostra a Figura $7 \mathbf{B}$, resultando em uma CSR superestimada ${ }^{[22]}$.

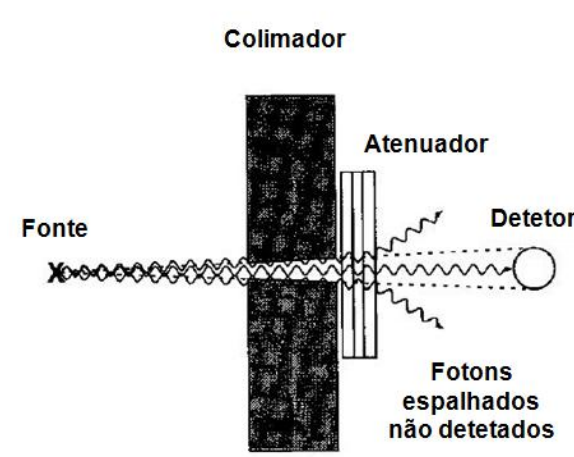

GEOMETRIA DE FEIXE ESTREITO

A

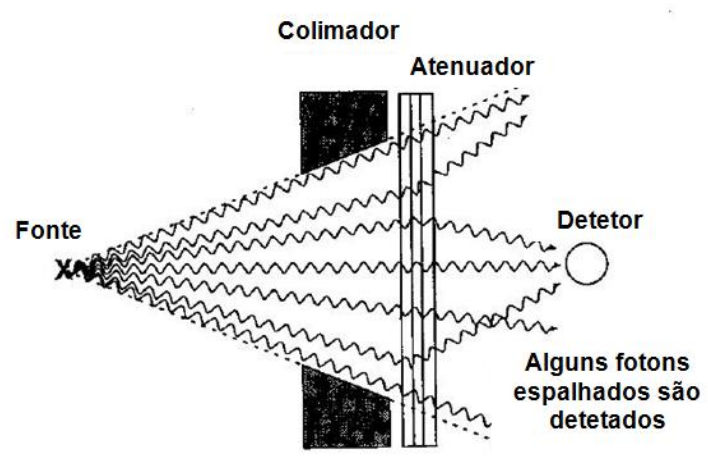

GEOMETRIA DE FEIXE LARGO

B

Figura 7 -: Geometrias de feixe estreito $(\mathbf{A})$ e de feixe largo (B) ${ }^{[22] .}$

Para fótons monoenergéticos, sob condições de geometria de feixe estreito, a probabilidade de atenuação permanece a mesma para cada espessura adicional da CSR adicionada no feixe. 
A redução da intensidade do feixe pode ser expressa como $(1 / 2)^{n}$ onde $\boldsymbol{n}$ é igual ao número de CSR.

Por exemplo, a fração de fótons monoenergéticos transmitidos através de 5 CSR's de material é $(1 / 2) \times(1 / 2) \times(1 / 2) \times(1 / 2) \times(1 / 2)=(1 / 2)^{5}=1 / 32=$ 0,031 ou 3,1\%, portanto, $97 \%$ dos fótons são atenuados (removidos do feixe).

É importante também compreender a relação entre $\mu$ (coeficiente de atenuação linear) e a CSR. Na equação $N=N_{0} e^{-\mu x}$ (relação exponencial entre o número de fótons incidentes $\left(N_{0}\right)$ e aqueles que são transmitidos $(N)$ através de uma espessura x sem interação), $N$ é igual a $N_{0} / 2$ quando a espessura do material absorvente é 1 CSR. Desta forma para um feixe monoenergético:

$$
\begin{aligned}
& N_{0} / 2=N_{0} e^{-\mu(C S R)} \\
& 1 / 2=e^{-\mu(C S R)} \\
& \ln (1 / 2)=\ln e^{-\mu(C S R)} \\
& 0,693=-\mu(C S R) \\
& \operatorname{CSR}=0,693 / \mu
\end{aligned}
$$

Para um feixe de fótons incidentes monoenergéticos, a CSR pode ser calculada a partir do coeficiente de atenuação linear, e vice-versa. Por exemplo:

$$
\begin{aligned}
& \text { a) } \mu=0,35 \mathrm{~cm}^{-1} \\
& \operatorname{CSR}=0,693 / 0,35 \mathrm{~cm}^{-1}=1,98 \mathrm{~cm} \\
& \text { b) } \operatorname{CSR}=2,5 \mathrm{~mm}=0,25 \mathrm{~cm} \\
& \mu=0,693 / 0,25 \mathrm{~cm}=2,8 \mathrm{~cm}^{-1}
\end{aligned}
$$

\subsection{Atenuação dos raios $X$}

Quando um feixe de raios $X$ colide com um dado material há três resultados possíveis:

1 - o fóton pode ser absorvido através da transferência da sua energia para os átomos do material do alvo em uma ou mais interações;

2 - ser espalhada durante uma ou mais interações ou,

3 - atravessar o material sem interação. 
Se o fóton é absorvido ou espalhado, é dito que o mesmo foi atenuado. Se 1000 fótons colidem sobre uma placa de material, por exemplo, e 200 são espalhados e 100 são absorvidos, então 300 fótons foram atenuados do feixe e 700 fótons foram transmitidos sem interação.

Os processos de atenuação podem ser mais complicados, pois pode ocorrer absorção parcial onde apenas uma parte da energia do fóton é retida no absorvedor ${ }^{[23]}$.

Nos fótons de baixa energia ( $<26 \mathrm{keV})$, o efeito fotoelétrico domina os processos de atenuação em tecido mole, pois a absorção fotoelétrica é altamente dependente da energia do fóton e do número atômico do absorvedor. Quando os fótons de energia mais elevadas interagem com materiais de baixo número atômico $Z$ (por exemplo, o tecido mole), ocorre o espalhamento Comptom. O espalhamento Rayleigh ocorre em imagens médicas com baixa probabilidade, compreendendo cerca de 10\% das interações em mamografia e 5\% em radiografia de tórax.

A Figura 8 mostra o gráfico dos coeficientes de atenuação de massa, em função da energia, para efeito fotoelétrico, Rayleigh, Compton, produção de pares e total para de tecido mole $(Z=7)^{[23]}$. A produção de pares contribui para a atenuação apenas em energias de fótons muito elevadas ( $>$ MeV 1,02), bem além do alcance da radiologia diagnóstica.

Coeficientes de atenuação de massa para tecido mole

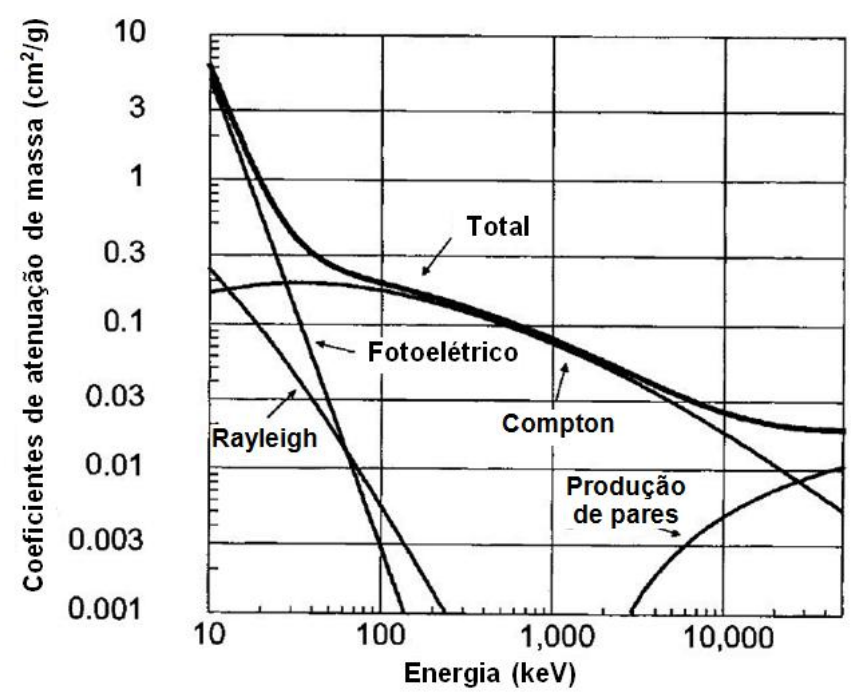

Figura 8 - Coeficientes de atenuação de massa 


\subsubsection{Atenuação do feixe de radiação $X$}

Se todos os fótons possuírem a mesma energia, feixe monoenergético, e se os fótons são atenuados sob condições de boa geometria, geometria de feixe estreito e sem transmissão de fótons espalhados, então o número de fótons I que penetra uma placa fina de matéria de espessura $x$ é:

$$
I=I_{0} \mathrm{e}^{-\mu x}
$$

onde $\mu$ é o coeficiente de atenuação do meio para os fótons e $I_{0}$ representa $o$ número de fótons no feixe antes da placa fina de matéria ser colocada em posição.

O número de fótons atenuados (absorvidos ou espalhados), $\mathrm{I}_{\mathrm{at}}, \mathrm{a}$ partir do feixe é:

$$
\begin{aligned}
I_{\text {at }} & =I_{0}-I \\
& =I_{0}-I_{0} e^{-\mu x} \\
& =I_{0}\left(1-e^{-\mu x}\right)
\end{aligned}
$$

O expoente de $\boldsymbol{e}$ não possui unidade, desta forma as unidades para $\boldsymbol{\mu}$ são $1 / \mathrm{cm}$ se a espessura $\boldsymbol{x}$ é expressa em centímetros, $1 /$ in se $\boldsymbol{x}$ é expressa em polegadas e assim por diante.

Um coeficiente de atenuação com unidades de 1/comprimento é chamado de coeficiente atenuação linear.

O comprimento da trajetória média é a distância média percorrida pelos raios $X$ antes da interação em um meio em particular. O comprimento da trajetória média é por vezes designada como a trajetória média livre ou comprimento de relaxamento e igual a $1 / \mu$, onde $\boldsymbol{\mu}$ é coeficiente de atenuação linear total. Ocasionalmente, a espessura de um meio de atenuação pode ser expressa em múltiplos da trajetória livre média dos fótons de uma determinada energia no meio. 
A probabilidade de um fóton atravessar uma placa de espessura $\boldsymbol{x}$ sem interagir é $\boldsymbol{e}^{-\mu x}$. Esta probabilidade é o produto das probabilidades de que 0 fóton não interaja por qualquer um dos cinco processos de interação:

$$
e^{-\mu x}=\left(e^{-\omega x}\right)\left(e^{-\tau x}\right)\left(e^{-\sigma x}\right)\left(e^{-k x}\right)\left(e^{-\pi x}\right)=e^{-(\omega+\tau+\sigma+k+\pi) x}
$$

Os coeficientes $\omega, \tau, \sigma, \kappa$, e $\pi$ representam as atenuações pelos processos de espalhamento $(\omega)$ efeito fotoelétrico $(\tau)$, espalhamento Compton $(\sigma)$, produção de pares $(K)$, e fotodesintegração $(\pi)$.

O coeficiente de atenuação linear total pode ser escrito como:

$$
\mu=\omega+T+\sigma+\kappa+\pi
$$

$\mathrm{Na}$ produção da radiografia diagnóstica, o espalhamento a fotodesintegração e a produção de pares são geralmente insignificantes, e $\mu$ é escrito como:

$$
\mu=T+\sigma
$$

Em geral, os coeficientes de atenuação variam de acordo com a energia dos raios $X$ e com o número atômico do material absorvedor. Os coeficientes de atenuação linear também dependem da densidade do absorvedor.

Coeficientes de atenuação de massa, obtidos pela divisão dos coeficientes de atenuação linear pela densidade $\rho$ do meio de atenuação, não variam com a densidade do meio:

$$
\mu_{\mathrm{m}}=\mu / \rho, \quad \omega_{\mathrm{m}}=\omega / \rho, \quad \mathrm{T}_{\mathrm{m}}=\mathrm{T} / \rho, \quad \sigma_{\mathrm{m}}=\sigma / \rho, \quad \mathrm{K}_{\mathrm{m}}=\kappa / \rho, \quad \pi_{\mathrm{m}}=\rho / \pi
$$

Os coeficientes de atenuação de massa são expressos, geralmente, em unidades de metros quadrados por quilograma, embora, às vezes, podendo ser expressos $\mathrm{em} \mathrm{cm}^{2} / \mathrm{g}$ ou $\mathrm{cm}^{2} / \mathrm{mg}$.

Coeficientes de atenuação massa total para ar, água, iodeto de sódio, e chumbo são traçados na Figura 9 em função da energia dos fótons incidentes ${ }^{[23]}$. 


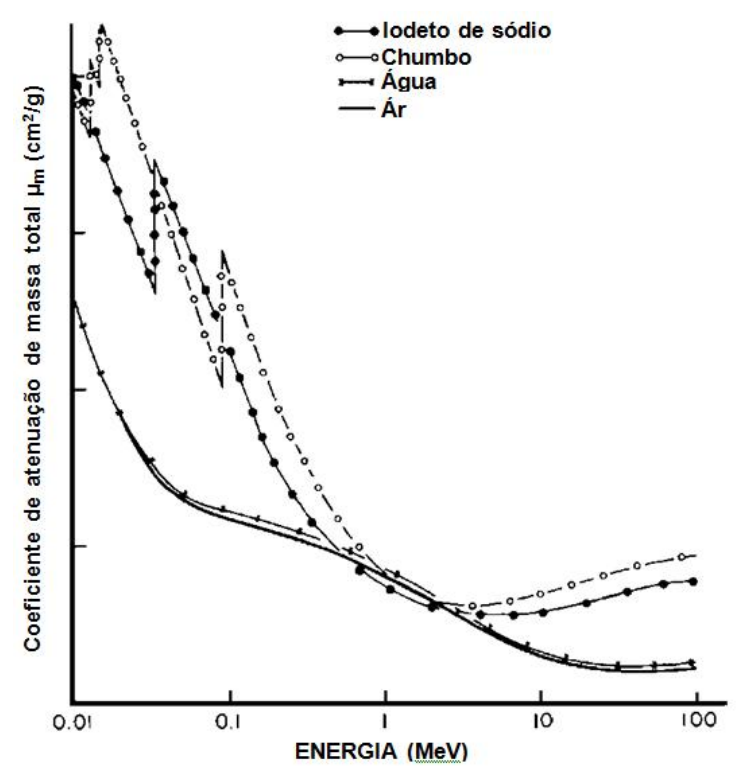

Figura 9 - Coeficientes de atenuação de massa total

\subsection{Variação na qualidade através de um feixe de raios $X$}

O kerma no ar de um feixe de raios $X$ do lado mais próximo do ânodo é menor do que o kerma no ar no lado do cátodo, porque os raios $X$ do lado do ânodo são atenuados por uma espessura maior do material do alvo, antes de emergir do ânodo.

Essa variação no kerma no ar através de um feixe de raios $X$ é chamada de efeito Heel (efeito anódico). A maior filtração do lado do ânodo aumenta a CSR do feixe de raios $X$ do cátodo para o lado do ânodo. $A$ diminuição do kerma no ar do cátodo para ânodo em um feixe de raios $X$ é menos perceptível em profundidades dentro de um paciente, porque a radiação em do lado do ânodo é mais penetrante ${ }^{[22]}$.

\subsection{Variação com a distância}

Em um meio não absorvente, a intensidade da radiação varia inversamente com o quadrado da distância da fonte. Por exemplo: se a distância for reduzida por um fator 2, a intensidade aumentará de um fator 4; se a distância for aumentada de um fator 2, a intensidade será reduzida por um fator 4. Esta relação, contudo, só é válida para o feixe incidente monoenergético. 
Para estimar a variação da exposição na entrada da pele de um paciente, deve-se ter em mente que a exposição ao nível do receptor de imagem deve permanecer constante (o valor necessário para produzir a imagem). Como a espessura do paciente é constante, o tamanho do campo deve ser ajustado geometricamente em função da distância, e a dose na pele do paciente aumentará com a diminuição da distância.

Em radiografia e fluoroscopia com equipamentos portáteis, a distância foco-pele não deve ser inferior a $30 \mathrm{~cm}$, e, em aparelhos fixos, $45 \mathrm{~cm}$. Para distância foco receptor de imagem menores que $100 \mathrm{~cm}$, a qualidade da informação diagnóstica torna-se inferior à medida que a distância diminui. Adicionalmente, maiores distância foco - receptor tem vantagens clínicas. Exames de tórax, não devem ter distância foco - receptor inferior a $120 \mathrm{~cm}$ (distância padrão $180 \mathrm{~cm})^{[24]}$.

\subsection{Efeito Heel (efeito anódico)}

A intensidade da radiação produzida por um aparelho de raios $X$ não é uniforme ao longo do campo devido à filtração que os fótons sofrem pelo próprio material do alvo quando são emitidos. Assim, dependendo da direção em que o fóton é emitido, sofre mais ou menos absorção, o que provoca uma variação na intensidade do feixe de aproximadamente $30 \%$ de uma extremidade à outra do campo, no eixo cátodo-ânodo ${ }^{[18]}$, portanto o efeito Heel refere-se a uma redução na intensidade do feixe de raios $X$ para do lado do ânodo no campo de raios $X$, Figura 10 . Os raios $X$ são produzidos isotropicamente no interior da estrutura de ânodo.

Os fótons direcionados para o lado do ânodo no campo passam por uma espessura maior do ânodo e, desta forma, sofrem uma maior atenuação daqueles fótons direcionados para o lado do cátodo no campo.

Para um determinado tamanho de campo, o efeito heel é menos proeminente com uma distância maior da fonte para imagem (Source-to-ImageDistance $S I D)$, porque o receptor de imagem subentende um ângulo menor do feixe. 
Para um melhor equilíbrio da transmissão dos fótons do raios $X$ incidentes no receptor de imagem, o tubo de raios $X$ é posicionado com 0 cátodo sobre as partes mais espessas do paciente e o ânodo sobre as partes menos espessas ${ }^{[23]}$.

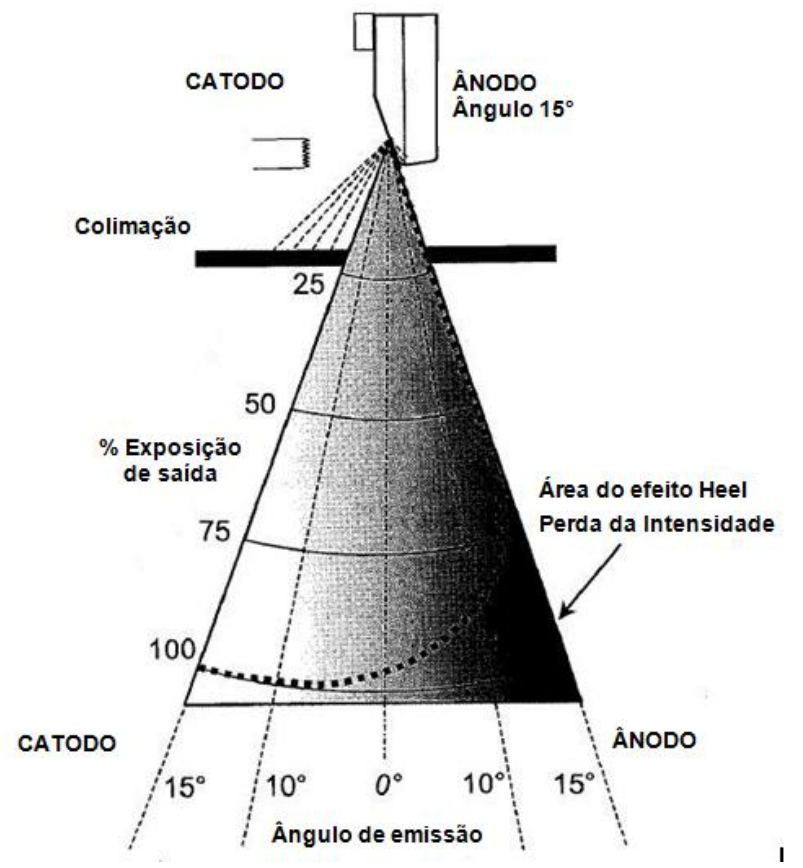

Figura 10 - O efeito Heel (efeito anódico) ${ }^{[23]}$ Erro! Indicador não definido.

Quanto menor o ângulo de inclinação do ânodo, menor será o tamanho aparente do ponto focal; o ângulo de inclinação utilizado varia de acordo com a aplicação pretendida. No entanto não são utilizados ângulos menores do que $12^{\circ}$ para aparelhos de Raios-X de diagnóstico, pois isto limitaria demasiadamente o tamanho do campo, além de aumentar a influência do efeito "heel" no que diz respeito à distribuição de intensidade do feixe ao longo do campo, tornando-a muito heterogênea ${ }^{[25]}$.

Conclui-se que o efeito "heel" tem influência significativa para imagens de objetos extensos devido à grande variação de intensidade entre um lado e outro do campo de exposição ${ }^{[18]}$, assim sendo a influência do efeito heel, nas medições realizadas pelo dispositivo desenvolvido, é insignificante, pois as das medições são realizadas com distâncias curtas entre o ponto focal, os filtros e o sistema de medição e em função de tais medições serem realizadas também sob condições de feixe estreito, ver item 3.5.1. 
O dispositivo de ensaio foi desenvolvido levando em consideração os requisitos da IEC 60522 de 1999 exige apenas que o material do alvo do ânodo do tubo de raios $X$, utilizado para a geração do feixe de radiação $X$ para a determinação da filtração inerente, seja o mesmo do ânodo do tubo de raios X sob ensaio, porém a norma IEC 60522 de 1976 determina que tanto o material do ânodo quanto o angulo deste sejam os mesmos, desta forma se a norma de 1976 for aplicada o efeito da angulação do ânodo deverá ser levado em consideração.

\subsection{Radiação Extra Focal}

A radiação extra-focal resulta dos elétrons do tubo de raios $X$ que atingem o ânodo fora da área de ponto focal. Uma pequena fração dos elétrons são espalhados do alvo e são acelerados de volta para o ânodo fora do ponto focal.

Estes elétrons criam uma fonte de raios $X$ de baixa intensidade sobre a superficie do ânodo. A radiação extra focal aumenta a exposição no paciente, gera indefinição geométrica e obscurecimento de fundo. Um colimador de chumbo pequeno colocado perto da janela de saída do tubo de raios $X$ pode reduzir a radiação extra focal por meio da interceptação dos raios $X$ que são produzidos em uma distância grande do ponto focal.

Tubos de raios $X$ que possuem envoltório de metal com o ânodo no mesmo potencial elétrico (ou seja, ânodo aterrado) reduzem a radiação extra focal porque os elétrons espalhados são atraídos para o envoltório de metal da mesma forma que àqueles que são atraidos para o ânodo ${ }^{[23]}$.

\subsection{Fatores que afetam a emissão de raios $X$}

A saída de um tubo de raios $X$ é muitas vezes descrita em termos de qualidade, quantidade e kerma no ar. A qualidade descreve a penetrabilidade de um feixe de raios $X$, os fótons de raios $X$ com maior energia têm uma maior CSR e maior "qualidade".

A quantidade se refere ao número de fótons que compõem o feixe. 
A exposição, é quase proporcional à fluência de energia do feixe de raios $\mathrm{X}$ e, desta forma tem qualidade e quantidade como características associadas. A eficiência de produção raios $X$, exposição, qualidade, e quantidade são determinados por seis fatores principais: material do alvo tubo de raios $X$, tensão, exposição, tempo de exposição, filtração do feixe e forma de onda do gerador. Os seis fatores são detalhados na sequencia.

1. O material do alvo (ânodo) afeta a eficiência da produção da radiação bremsstrahlung, com a intensidade de saída aproximadamente proporcional ao número atômico. Os elétrons Incidentes são mais propensos a ter interações em materiais com alto numero atômico. As energias dos raios $X$ característicos produzidos no alvo dependem do material do alvo, portanto, o material alvo afeta a quantidade dos fótons bremsstrahlung e a qualidade da radiação característica.

2. Tensão do tubo $(k \vee p)$ determina a energia máxima no espectro bremsstrahlung e afeta a qualidade do espectro de saída. Além disso, a eficiência da produção de raios $X$ está diretamente relacionada à tensão do tubo. A intensidade de saída é aproximadamente proporcional ao quadrado do kVp na faixa de energia de diagnóstico. A Figura 11 mostra que a intensidade de saída do tubo de raios $X$ varia significativamente com a tensão do tubo $(k \vee p)$. No exemplo da Figura 11, a mesma corrente do tubo e tempo de exposição (mAs) são comparados de 60 a 120 kVp e a área relativa em cada espectro segue aproximadamente uma dependência quadrática (a radiação característica é ignorada) ${ }^{[23]}$.

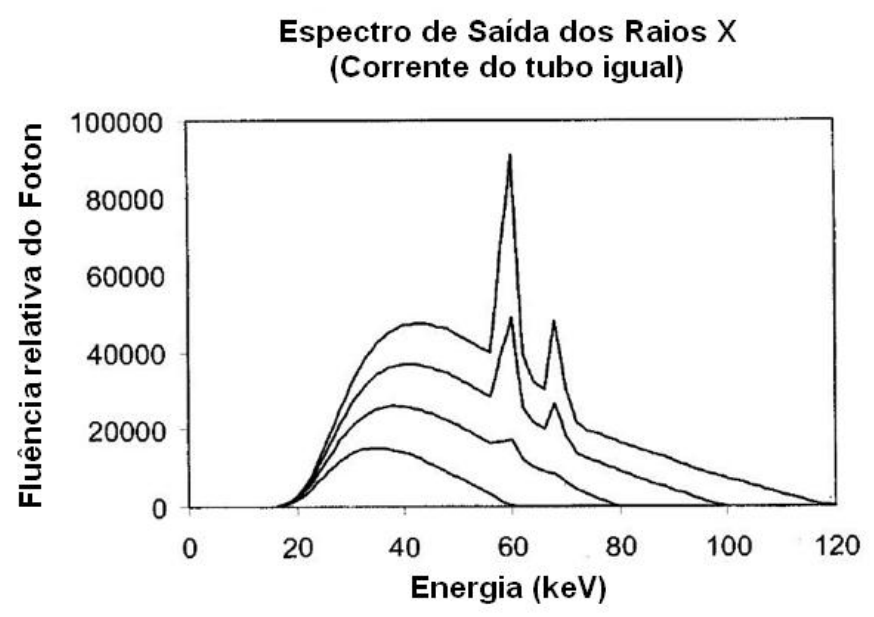

Figura 11 - Espectro de saida dos raios $\mathrm{X}^{[23]}$.. 
3. A corrente do tubo $(\mathrm{mA})$ é igual ao número de elétrons que fluem a partir do cátodo para o ânodo por unidade de tempo. A exposição do feixe para um dado kVp e filtração é proporcional à corrente do tubo.

4. O tempo de exposição é a duração da produção dos raios X. A quantidade de raios $X$ é diretamente proporcional ao produto da corrente do tubo e pelo tempo de exposição (mAs).

5. A filtração do feixe modifica a quantidade e a qualidade do feixe de raios $X$ pela remoção seletiva dos fótons de baixa energia do espectro. Isso reduz o número de fótons (quantidade) e desloca a energia média para valores mais altos, modificando a qualidade.

6. A forma de onda do gerador afeta a qualidade do espectro de raios $X$ emitido. Para a mesma tensão $(k \vee p)$, um gerador monofásico fornece uma diferença de potencial média menor do que um gerador trifásico ou de alta frequencia. Tanto a qualidade quanto a quantidade do espectro de raios $X$ são afetados, Figura 12. Resumindo, a quantidade de raios $X$ é aproximadamente proporcional ao Z Alvo multiplicado pela tensão $(k \vee p)$ e pelo produto corrente tempo (mAs). A qualidade dos raios $X$ depende da tensão (kVp), da forma de onda do gerador e da filtração do tubo. A exposição depende tanto da quantidade quanto da qualidade do feixe raios $X$.

A Figura 12 mostra que a intensidade do espectro de saída (Bremsstrahlung) para a mesma tensão tubo (kVp), corrente do tubo e tempo de exposição (mAs) demonstram uma energia efetiva mais elevada e um saída maior de um gerador com forma de onda de tensão trifásica ou de alta frequencia (aproximadamente 5\% da ondulação da tensão), em comparação com um gerador de forma de onda monofásica (100\% de ondulação de tensão) ${ }^{[23]}$. 


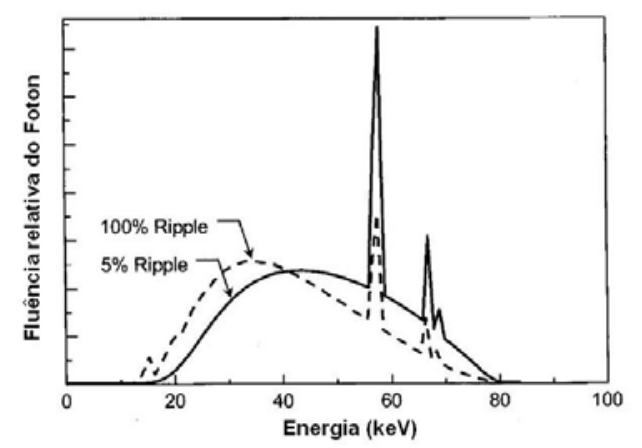

Figura 12 - Comparação de espectros gerados com diferentes formas de onda

\subsection{Filtração inerente e filtração adicional}

A filtração é a modificação de característica da radiação ionizante ao atravessar uma matéria. A filtração pode ser uma absorção preferencial de certos componentes de radiação $X$ ou radiação gama polienergéticas, acompanhando sua atenuação ou uma modificação da distribuição da intensidade de radiação, sobre uma seção transversal de um feixe de radiação.

Em um equipamento de raios $X$ a atenuação do feixe ocorre em função da ação tanto da filtração inerente do tubo de raios $x$ quanto da filtração adicional $^{[26]}$.

A determinação da filtração de um gerador de raios $X$ para diagnóstico médico é extremamente importante na medida em que a redução da filtração de um gerador de raios $X$ pode resultar no aumento da dose na pele do paciente e alterar a qualidade da imagem radiográfica, em contrapartida o aumento excessivo da filtração não contribui para a qualidade de imagem e irá diminuir a intensidade do feixe resultando em uma má qualidade de imagem ou no aumento da dose no paciente proporcionado pelo tempo de exposição prolongado, que é necessário para compensar o efeito da filtração excessiva no feixe de raios $X$. 


\subsubsection{Filtração inerente}

É a filtração com equivalência de qualidade igual à efetuada pelos materiais irremovíveis que o feixe de radiação atravessa, antes de emergir do conjunto de fonte de radiação $X$, ou de componentes do mesmo.

Para um conjunto-emissor de radiação $X$ (cúpula com o tubo de raios $X$ inserido), a filtração inerente é expressa em espessura de um material de referência que, para uma tensão e forma de onda especificadas, fornece a mesma qualidade de radiação, em termos de primeira camada semirredutora $^{[26]}$.

A filtração inerente inclui a espessura (1 a $2 \mathrm{~mm}$ ) do vidro do envoltório do tubo de raios $\mathrm{X}$ e do metal na janela de saída (filtro irremovível).

$\mathrm{O}$ vidro (Dioxido de Silicio - $\mathrm{SiO}_{2}$ ) e o alumínio têm propriedades de atenuação semelhantes ( $Z=14$ e $Z=13$, respectivamente) e atenuam de maneira efetiva todos os fótons de raios $X$ com energias abaixo de $15 \mathrm{keV}$ aproximadamente. Tubos de raios $X$ específicos para mamografia, por outro lado, requerem materiais de janela como o berílio $(Z=4)$ para melhorar a transmissão de raios $X$ de baixa energia ${ }^{[23]}$. A filtração inerente pode incluir a atenuação efetuada pelo óleo isolante presente no interior da cúpula na qual o tubo de raios $X$ esta inserido e a atenuação efetuada pelo espelho do sistema de colimação dos raios $X$ que é responsável pelo campo luminoso utilizado para determinar a área de irradiação, pois tal espelho esta posicionado na saída de radiação do conjunto fonte de radiação $X$.

A Figura 13 mostra a imagem de um conjunto fonte de radiação $X$, formado pelo conjunto emissor, cúpula e tubo de raios $X$ inserido, e pelo sistema de colimação e a representação do mesmo através de desenho ilustrando os materiais cuja filtração inerente deve ser verificada. 


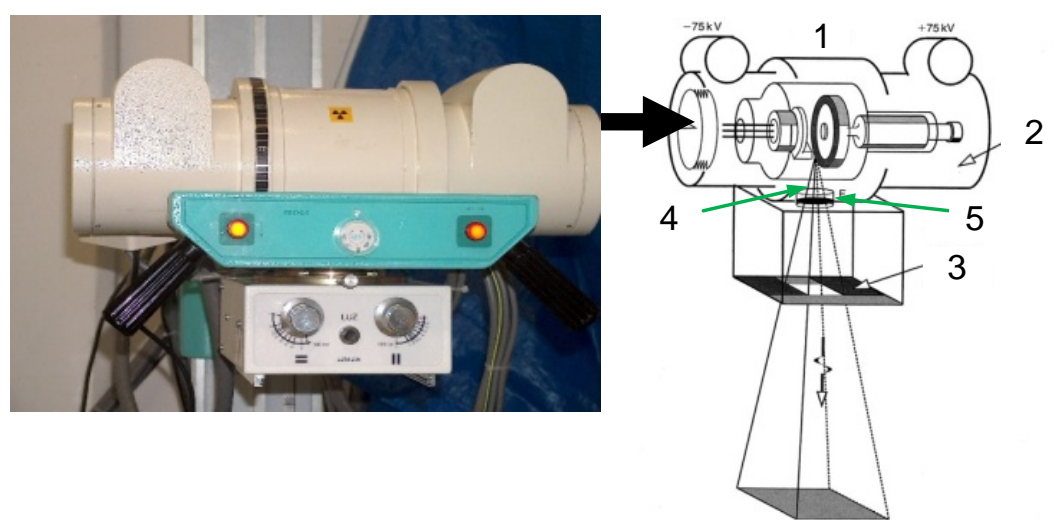

1 - Vidro

2 - Óleo

3 - Colimador

4 - Janela de saída

5 - Filtro adicional

Figura 13 - Imagem de um conjunto fonte de radiação $X^{[27]}$.

\subsubsection{Filtração adicional}

A filtração adicional é a filtração com equivalência de qualidade efetuada por filtros adicionais e outros materiais removíveis colocados no feixe de radiação, entre a fonte de radiação e o paciente ou um plano especificado $^{[26]}$.

A filtração adicional remove seletivamente os fótons de energia mais baixa, resultando em melhor aproximação de um feixe monoenergético e a diferença entre sucessivas CSR's torna-se cada vez menor.

Os filtros adicionais se referem às folhas de metal colocadas intencionalmente no feixe de radiação para mudar a energia efetiva. De maneira geral, na radiologia diagnóstica, os filtros adicionais atenuam os raios $X$ de baixa energia que não têm praticamente nenhuma chance de atravessar 0 corpo do paciente e atingir o detector de raios $X$, reduzindo desta forma a dose ao paciente através da eliminação da radiação de baixa energia que não irá contribuir na formação da imagem radiográfica.

O alumínio é o material mais comum empregado na fabricação dos filtros adicionais, Figura 14. Outros materiais comumente utilizados, não da mesma forma que o alumínio, são o cobre e materiais plásticos (por exemplo, polimetilmetacrilato - PMMA).

Na mamografia são utilizados filtros de filtros de molibdênio e ródio para auxiliar na modelagem do espectro de raios $X$, ressaltando fluorescências características de baixa energia que contribuem para a formação de imagens de melhor qualidade e resolução. Filtros terrosos, tais como érbio, são por vezes utilizados em radiografia de tórax para reduzir a dose no paciente ${ }^{[23]}$. 


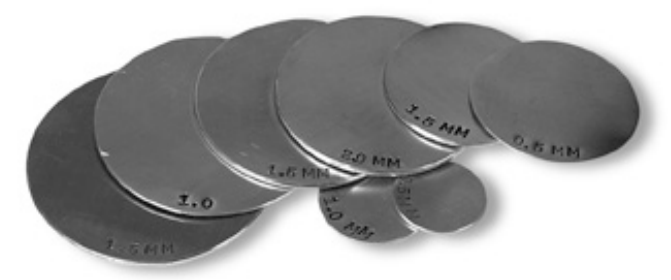

Figura 14 - Filtros adicionais de várias espessuras e tamanhos ${ }^{[28]}$

\subsection{Geradores de raios X}

O gerador de raios $X$ para diagnóstico médico é um equipamento eletroeletrônico que pode ter ou não mecanismos servo-comandados (motorizados) para o posicionamento do paciente. A geração de raios $X$ se dá pela conversão da energia elétrica (tensão de aceleração do elétron) e da energia cinética (desaceleração do elétron quando da sua interação com o núcleo) em radiação $X$. A maior parte desta conversão de energia é perdida em forma de calor.

A conversão de energia é controlada através dos seguintes parâmetros:

- kV (tensão de aceleração do elétron) que define a profundidade da radiografia ou seja o quanto o feixe de radiação estará "endurecido";

- mA (corrente do filamento) é responsável pelo efeito termiônico no filamento do tubo de raios $X$ no qual é gerada a nuvem eletrônica que é chamada carga espacial e será responsável pelo feixe de elétrons que será acelerado para o ânodo. Quanto maior for a corrente no tubo, maior será a quantidade de elétrons produzidos no feixe e, portanto, maior quantidade de fótons de raios $X$.

- Tempo (tempo de aplicação de carga ou exposição) define o tempo de exposição do paciente a radiação.

$O$ equipamento de raios $X$ é constituído basicamente de um gerador de alta-tensão um tubo de raios $X$ inserido em uma cúpula de proteção e um comando eletrônico responsável pelo ajuste e seleção dos parâmetros de aplicação de carga. 
O gerador de alta-tensão tem a função de elevar a tensão de rede para tensões da ordem de $40 \mathrm{kV}$ a $150 \mathrm{kV}$, essas tensões elevadas são necessárias para a aceleração dos elétrons presentes, através do efeito termiônico, no filamento do tubo de raios $\mathrm{X}$.

O comando eletrônico do gerador de alta-tensão realiza o controle dos parâmetros de aplicação de carga que o tubo de raios $X$ será submetido, os controles são realizados pelo operador que define a tensão $(\mathrm{kV})$ o tempo (s) e a corrente $(\mathrm{mA})$ ou produto corrente tempo ( $\mathrm{mAs})$ necessários para realizar a radiografia em função da área do corpo que se deseja radiografar.

\subsubsection{Tubo de raios $X$}

O tubo de raios $X$ é formado pelo o cátodo, ânodo, rotor (para tubo de raios $X$ com ânodo giratório) e apoio dessas estruturas, sendo que o tubo é selado em um invólucro de vidro ou metal, figura 15, sob alto vácuo.

O alto vácuo impede elétrons colidam com moléculas de gás e é necessário em todos os dispositivos de feixe de elétrons. Em tubos de raios $\mathrm{X}$ antigos, moléculas de gás presas infiltram-se a partir das estruturas tubulares e degradam ligeiramente o vácuo.

O vácuo torna possível uma produção mais eficaz de raios $X$ e prolonga a vida do tubo. A presença de gás dentro da ampola diminui o fluxo de elétrons do cátodo ao ânodo, produzindo menos raios $X$ e mais calor diminuindo a durabilidade do tubo ${ }^{[29]}$.

Os raios $X$ são emitidos em todas as direções a partir do ponto focal, no entanto, os raios $X$ que emergirem através da janela do tubo de raios $X$, constituirão o feixe útil.

Os raios $\mathrm{X}$, destinados ao uso industrial e médico, são gerados numa ampola de vidro, denominada tubo de Coolidge ${ }^{[30]}$, Figura 15, que possui basicamente um eletrodo negativo, denominado cátodo, e um positivo, ânodo. Estes elementos estão dispostos dentro de um invólucro de vidro no qual possui alto vácuo e pressões menores que $1,3 \times 10^{-6} \mathrm{kPa}$. 


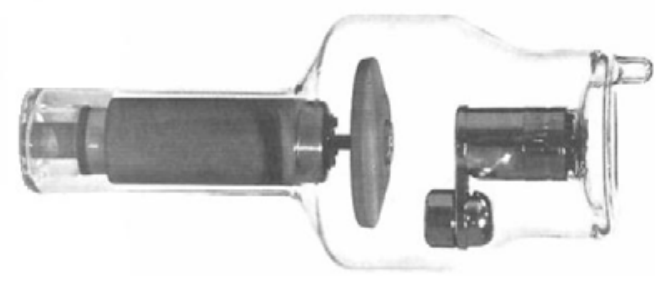

Figura 15 - Tubo de raios $X$ foco duplo com ânodo giratório.

Os elementos básicos de um tubo de raios-X estão representados na Figura 16 e alguns serão descritos sucintamente a seguir.

\subsubsection{Cúpula do tubo de Raios $\mathrm{X}$}

A cúpula de raios $X$ é preenchida com óleo isolante que têm a finalidade de dissipar o calor gerado pelo ânodo e de isolar eletricamente o tubo de raios $X$ da cúpula que, por ser metálica, pode gerar caminhos descargas disruptivas (arcos-voltaicos) entre a superfície interna cúpula e o tubo de raios $X$, tais descargas surgem em função da alta-tensão aplicada entre o cátodo e o ânodo do tubo de raios $X^{[17]}$.

Uma cúpula de raios $X$ típica contém uma câmara para permitir a expansão de óleo, uma vez que absorve o calor durante a operação. Se o óleo se aquece excessivamente, a câmara de expansão ativa um microswitch (chave) que desliga o sistema até resfriamento do tubo de raios $X$, Figura $16 \mathrm{e}$ Figura 17. A proteção de chumbo no interior da cúpula atenua os raios $X$ que são emitidos em todas as direções, sendo que há uma abertura na blindagem denominada de janela de saida de radiação do tubo de raios $X$.

A cúpula de proteção deve possuir proteção suficiente para atender os limites de radiação de fuga de acordo com a legislação em vigor (portaria $453^{[31]}$.

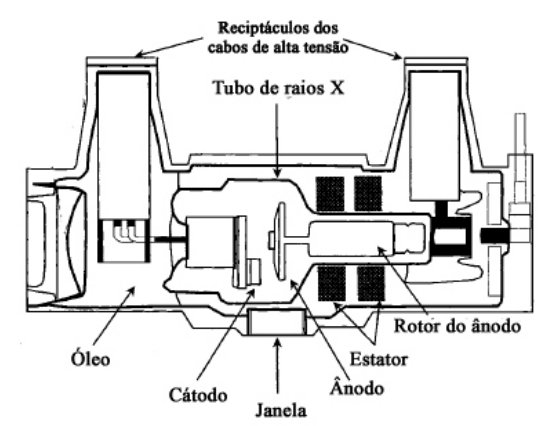

Figura 16 - Diagrama esquemático da cúpula (carcaça) do tubo de raios $X^{[30]}$. 


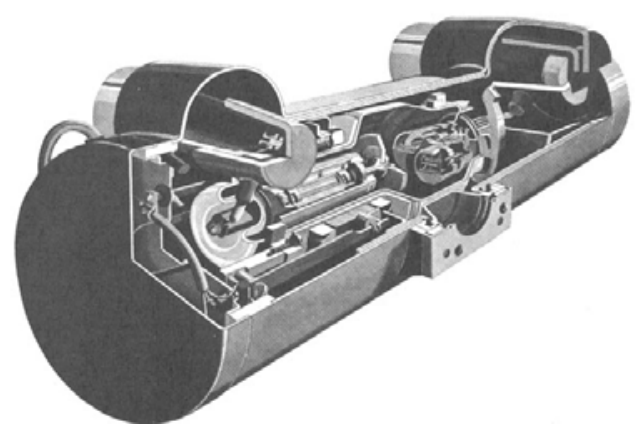

Figura 17 - Carcaça recobrindo o tubo de raios X com ânodo giratório ${ }^{[23]}$.

Quando os raios X são produzidos eles são emitidos de forma isotrópica, isso é, com a mesma intensidade em todas as direções, porém somente a janela do tubo permite a passagem do feixe útil do raios $\mathrm{X}$, Figura $18^{[29]}$.

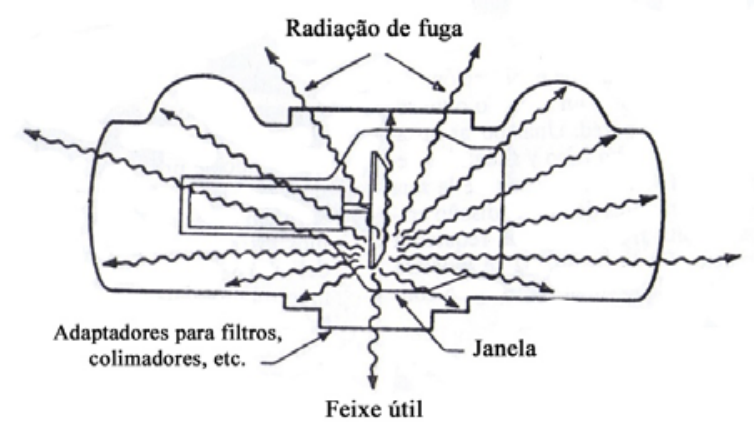

Figura 18 - Redução da radiação de fuga por meio da carcaça protetora ${ }^{\text {[29] }}$.

Os raios $\mathrm{X}$ emitidos através da janela são conhecidos como feixe útil. Os restantes que escapam da carcaça protetora são radiação de fuga (não contribui com a informação diagnóstica e gera uma dose desnecessária para o paciente e operador) ${ }^{[29]}$.

Uma carcaça adequadamente projetada reduz o nível de radiação de fuga a menos de $12 \mathrm{mGy}$ a $1 \mathrm{~m}\left(26 \mu \mathrm{C} / \mathrm{Kg}^{-\mathrm{h}}\right.$ a $\left.1 \mathrm{~m}\right)$ quando se utiliza em condições máximas de funcionamento ${ }^{[29]}$.

A janela do tubo por onde passa o feixe útil é uma parte do invólucro de vidro, formando uma área de aproximadamente $5 \mathrm{~cm}^{2}$ para raios $X$ diagnóstico e $3 \mathrm{~cm}^{2}$ para raios $X$ odontológico, permitindo a passagem de raios $X$ com o mínimo de absorção possível ${ }^{[32]}$. 


\subsubsection{Cátodo}

A região catódica constitui o terminal negativo do tubo responsável pela emissão de elétrons a partir de um circuito secundário sendo também responsável por focalizá-los em forma de um feixe definido até o ânodo. O cátodo é constituído de duas partes principais: filamento e copo focalizador, Figura 19. A corrente do circuito do filamento aquece o filamento que libera elétrons por emissão termiônica ${ }^{[23] .}$

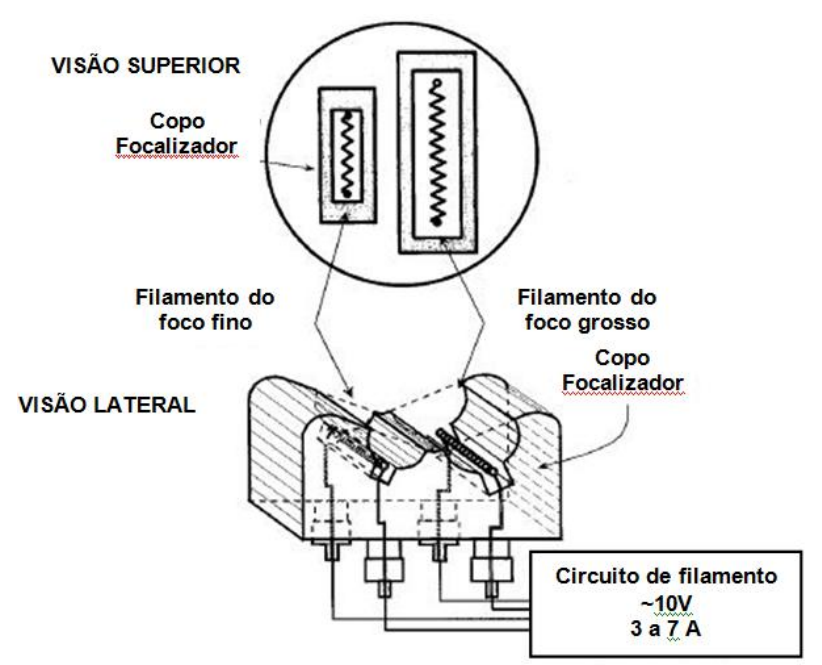

Figura 19 - Filamento e o copo focalizador do tubo de raios $X$

O filamento é um fio em forma de espiral de tungstênio toriado (cerca de 1\% a 2\% de tório). Essa liga apresenta alto ponto de fusão, logo não vaporiza facilmente. Assim, quando uma corrente da ordem de 3,5 a 7A atravessa o filamento, provoca o aquecimento do mesmo. Ao ser atingida a temperatura de aproximadamente $2000^{\circ} \mathrm{C}$, parte dos elétrons pode atingir energia térmica suficiente para romper a ligação com os átomos. Esse fenômeno recebe a denominação de efeito termiônico ${ }^{[33]}$.

A carga positiva no metal do cátodo atrai elétrons, formando uma nuvem eletrônica ao redor do filamento. Esse está contido no interior de uma cúpula focalizadora, normalmente constituída de níquel e mantida sob o mesmo potencial que o filamento.

Devido à geometria da cúpula, gera-se um campo elétrico entre o filamento e o ânodo que impede a dispersão da nuvem eletrônica. 
A maior parte dos equipamentos de raios $X$ possui dois focos um pequeno denominado foco fino $(0,3 \mathrm{a} 1 \mathrm{~mm})$ e um grande chamado foco grosso $(1,3 \text { a } 1,5 \mathrm{~cm})^{[15]}$.

\subsubsection{3 Ânodo}

O ânodo, eletrodo positivo, é comumente formado por um bloco de cobre ou molibdênio que, em sua face externa, existe uma fina camada de tungstênio, Figura 20. Este é chamado de "alvo" (descrito a seguir) e o tungstênio é utilizado devido ao fato de ter um alto ponto de fusão, dessa forma suporta o calor extremo em decorrência da colisão dos elétrons com o material do alvo. Além disso, esse material possui um número atômico (74) o que aumenta a eficiência na produção de raios $X^{[18]}$.

O ânodo tem quatro funções básicas:

- Gerar raios X;

- Receber os elétrons emitidos pelo cátodo e conduzi-los através do tubo aos cabos conectados de alta-tensão, onde se conclui que o ânodo é um condutor elétrico;

- Ser condutor térmico. Quando os elétrons se chocam com o ânodo, mais de 99\% de sua energia cinética é convertida em calor, este deve ser eliminado rapidamente;

- Funcionar como suporte para o alvo.

Existem dois tipos de ânodo, o fixo e o giratório ${ }^{[18]}$.

- Ânodo fixo: O ânodo fixo é utilizado em tubos onde não são necessárias altas correntes, como em equipamentos de raios $X$ odontológicos, unidades portáteis, etc. A Figura 20 ilustra um ânodo fixo.

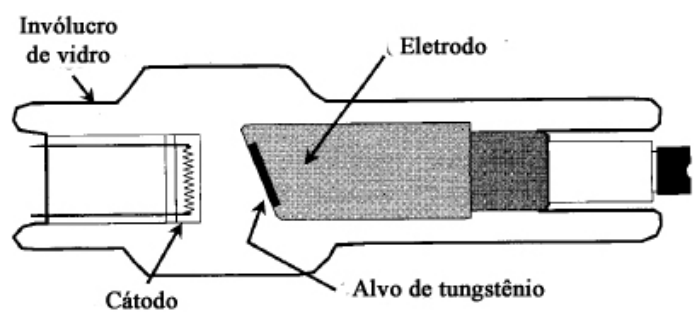

Figura 20 - Componentes do ânodo fixo ${ }^{[23]}$. 
- Ânodo giratório: A maioria dos tubos de unidades de diagnóstico possui ânodo rotatório devido à utilização de altas intensidades de raios $\mathrm{X}$ em um periodo curto ${ }^{[32]}$. A Figura 21 ilustra um ânodo giratório.

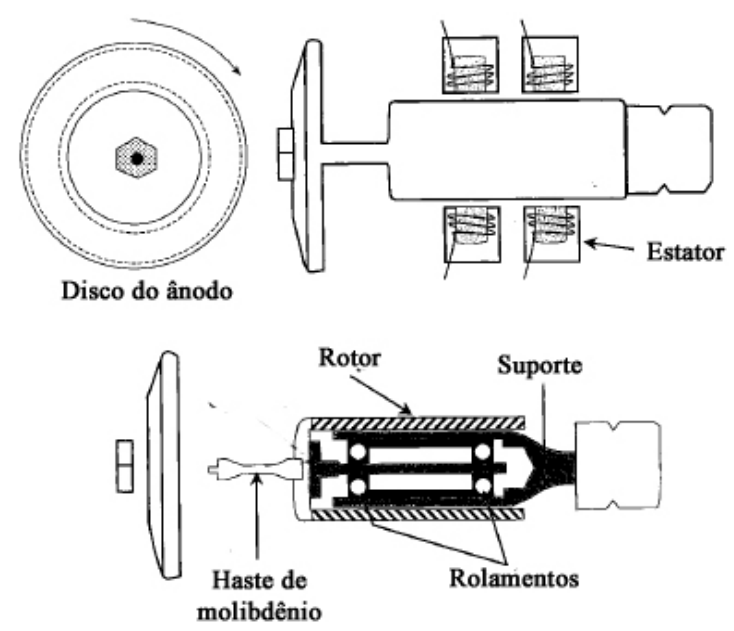

Figura 21 - Componentes do ânodo giratório ${ }^{[18]}$.

O alvo é a área do ânodo onde ocorre o impacto direto dos elétrons. No ânodo fixo o alvo é uma pequena parte do ânodo feito de uma liga de tungstênio e rênio, enquanto que no ânodo giratório o alvo é toda uma região circular do disco, também feito de uma liga de tungstênio e rênio mais molibdênio. $O$ ponto focal é a área do alvo que são emitidos os raios $X$. $O$ ângulo do alvo influencia na formação do ponto focal efetivo; conforme diminui o ângulo do alvo, reduz-se também o ponto focal efetivo, Figura $22^{\text {[29] }}$.

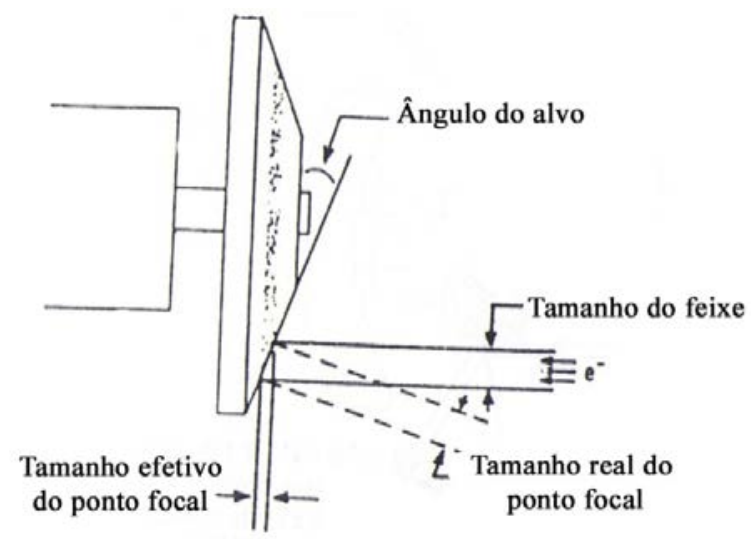

Figura 22 - Influência do ângulo do alvo em relação ao ponto focal ${ }^{[29]}$. 


\subsubsection{Ponto focal}

$\mathrm{Na}$ produção de raios $X$ apenas uma parte da região anódica está envolvida, que recebe a denominação de ponto focal. O ponto focal constitui a área do alvo onde ocorrerá a colisão dos elétrons oriundos do filamento. Logo é nessa região que se tem origem a produção de radiação $X$.

As dimensões dessa região no tubo de raios $X$ variam de $0,1 \mathrm{~mm}$ a 2 $\mathrm{mm}$ de acordo com a aplicação diagnóstica, sendo que o tamanho do ponto focal está diretamente ligado ao poder de resolução do aparelho de raios $X$, ou seja, de sua capacidade em identificar estruturas pequenas ${ }^{[33]}$.

Assim, quanto maior o ponto focal, menor a área para a ocorrência de interações e como consequência a resolução da imagem será melhor, já que a penumbra e distorção da imagem são menores. Porém, a presença de uma área de colisão pequena acarretará em um aumento de temperatura, gerando deste modo danos ao alvo.

O tamanho e a forma do ponto focal dependem do tamanho do filamento bem como das características de construção do dispositivo de focalização do tubo. Grande parte dos aparelhos de raios $X$ possui dois filamentos um grande e outro menor, produzindo deste modo imagens com menor e maior poder de resolução de acordo com a necessidade diagnóstica.

\subsubsection{5 Ângulo do Ânodo e tamanho do ponto focal}

O ângulo do ânodo é definido como o ângulo da superfície do alvo em relação ao raio central do campo de radiação $X$. Os ângulos do ânodo em tubos de raios $X$ para diagnóstico, além de alguns tubos de mamografia, variam de 7 a 20 graus, sendo o ângulo de 12 graus o mais comum. Na Figura 23 é mostrado que o ângulo do ânodo (alvo) é definido como o ângulo da superfície do alvo em relação ao raio central e o comprimento focal, como projetado no eixo central, é encurtado, de acordo com o Princípio da linha de foco (inferior direito da Figura 23) ${ }^{[23]}$. 
O tamanho do ponto focal é definido de duas maneiras:

1 - Ponto focal real - é a área em que o ânodo é atingido por elétrons, sendo determinado principalmente pelo comprimento do filamento e da largura da ranhura do copo focalizador do cátodo.

2 - Ponto focal efetivo - é o comprimento e a largura do ponto focal, tal como projetado para baixo do raio central no campo de radiação $X$. A largura do ponto focal efetivo é igual à largura ponto focal real e, portanto, não é afetado pelo ângulo do ânodo. No entanto, o ângulo do ânodo faz com que o comprimento do ponto focal efetivo seja menor que o comprimento real do ponto focal.

Os comprimentos do ponto focal efetivo e real estão relacionados da seguinte forma:

Distância focal efetiva $=$ comprimento focal real $X \sin \theta$

Onde $\theta$ é o ângulo do ânodo. Este encurtamento do comprimento focal, vista abaixo do raio central, é chamado de Princípio da linha de foco ${ }^{[23]}$.

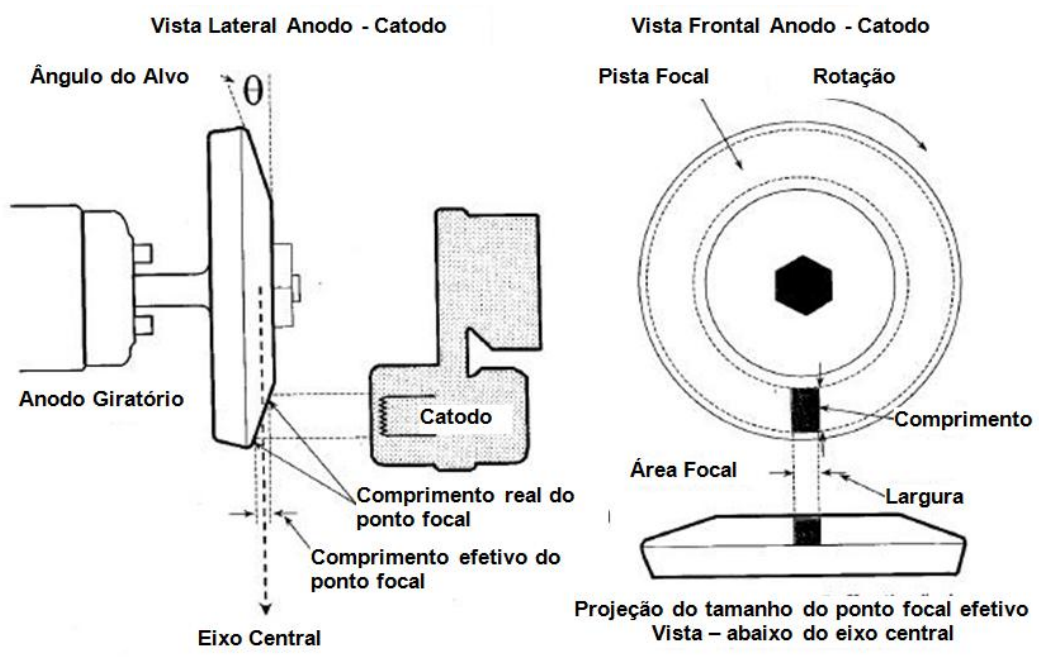

Figura 23 - Vistas lateral, frontal e abaixo do eixo central do Anodo-Catodo.

Há três questões principais a serem consideradas para a escolha do ângulo do ânodo. O ângulo menor do ânodo fornece um ponto focal efetivo menor para mesma área focal real. No entanto, um ângulo de ânodo pequeno limita o tamanho do campo de raios $X$ utilizável devido ao corte do feixe. $A$ cobertura do campo é menor para distâncias pequenas entre o ponto focal e o detetor. O ângulo do ânodo ideal depende da aplicação da imagem clínica. 
Na Figura 24 é demonstrado que:

- A: A cobertura de campo e o comprimento do ponto focal efetivo variam de acordo com o ângulo do ânodo. A: Um ângulo anódico grande proporciona uma cobertura de campo satisfatória em uma determinada distância, no entanto, para alcançar um ponto focal efetivo pequeno, uma área focal real pequena limita a potência;

- B: Um ângulo de ânodo maior oferece uma boa cobertura de campo, e possibilita carga de alta potência que exige uma grande área focal, no entanto, ocorrem indefinições geométricas e degradação da imagem;

- C: Um ângulo anódico menor limita a cobertura do campo em uma determinada distância, no entanto, um ponto focal efetivo menor é obtido com uma grande área focal para potência alta ${ }^{[23]}$.

O ângulo menor do ânodo (cerca de 7-9 graus) é desejável para receptores de imagem com campo de visão menor, tais como equipamentos e cineangiográfia e neuroangiografia, onde a cobertura de campo é limitada pelo diâmetro do intensificador de imagem.

Os ângulos maiores do ânodo (aproximadamente 12 a 15 graus) são utlizados nos trabalhos em radiográfia geral, pois são necessários para que se possa atingir uma grande área de cobertura de campo em distâncias pequenas entre o ponto focal e o receptor de imagem ${ }^{[23]}$.

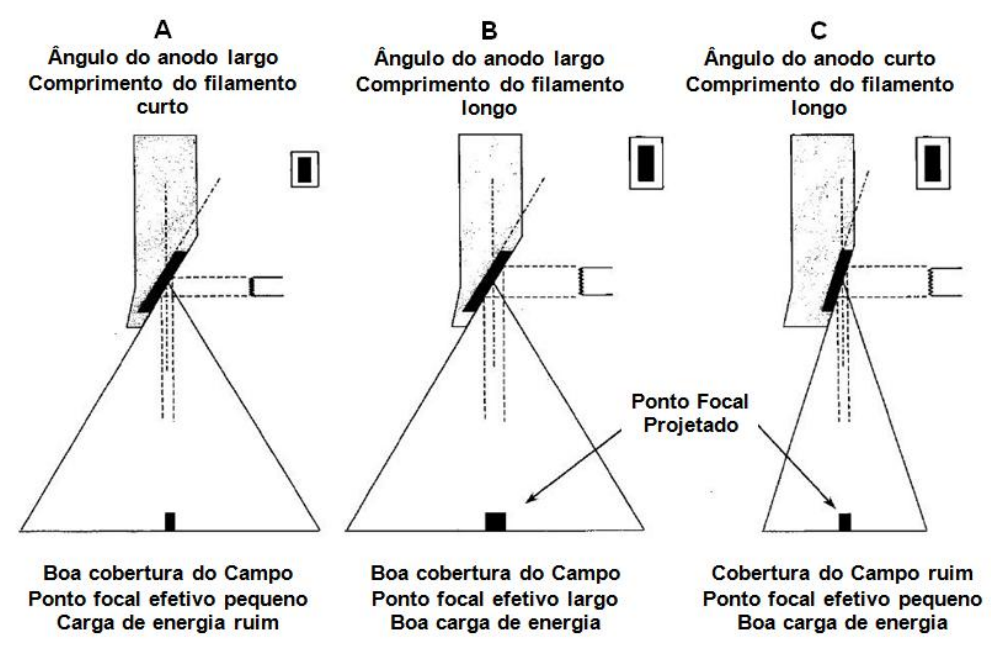

Figura 24 - Relação entre o ângulo do ânodo e a cobertura do campo de radiação. 
O comprimento do local focal efetivo varia de acordo com a posição no plano de imagem, na direção o ânodo-cátodo (A-C). Na direção do lado do ânodo do campo projetado o comprimento do ponto focal diminui, ao passo que aumenta para o lado do cátodo do campo. A Figura 25 mostra que a variação do tamanho do ponto focal efetivo no campo da imagem ocorre ao longo da direção do cátodo para o ânodo. As distribuições do ponto focal são plotados em função do ângulo de projeção em graus a partir do eixo central, o paralelo (eixo vertical) e perpendicular (eixo horizontal) ${ }^{\text {[23]. }}$

Na largura, o tamanho do ponto focal não muda significativamente com a posição no plano de imagem.

O tamanho do ponto focal nominal (largura e comprimento) é especificado no raio central do feixe.

$O$ raio central é geralmente um linha do ponto focal para o receptor de imagem que é perpendicular ao eixo $A C$ do tubo de raios $X$ e perpendicular ao plano de uma imagem posicionada corretamente no receptor. Na maioria das imagens radiográficas, o raio central corta o campo do detector ${ }^{[23]}$.

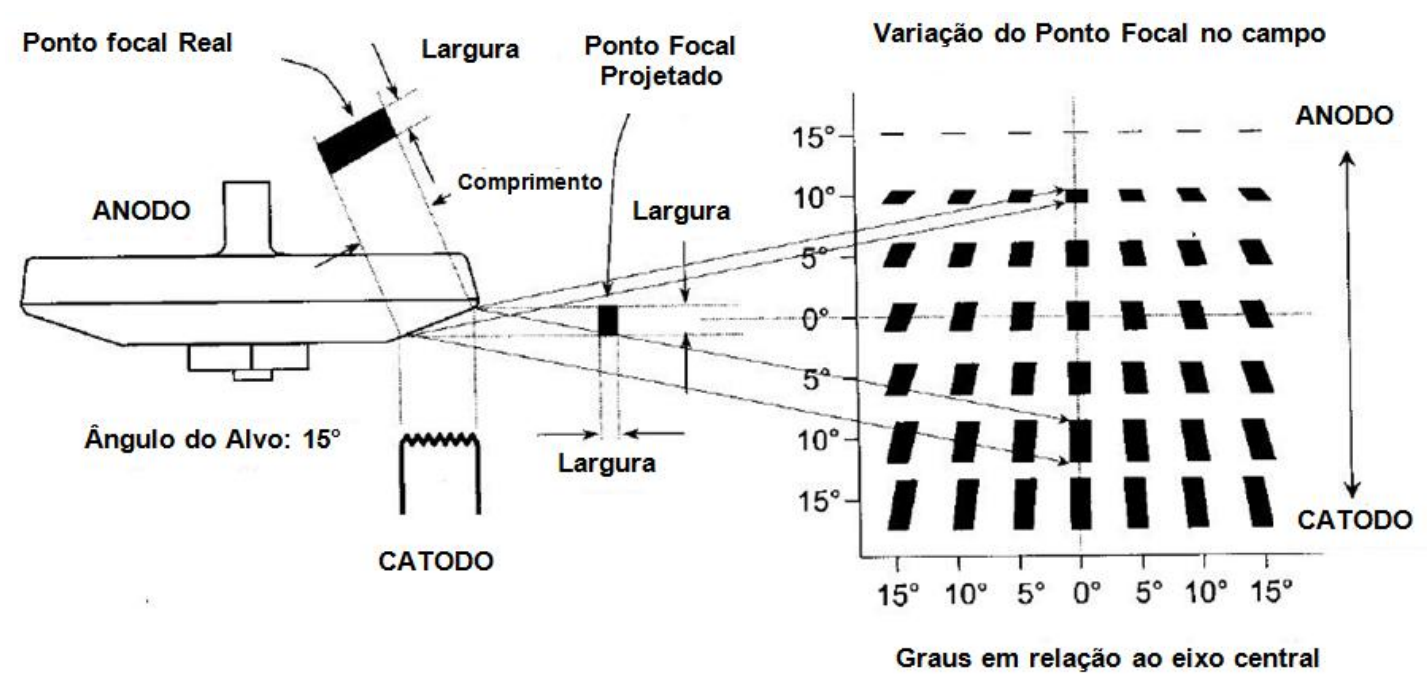

Figura 25 - A variação do tamanho do ponto focal efetivo ${ }^{[23]}$. 


\subsubsection{Dispositivos limitadores de feixe (colimador)}

Os dispositivos limitadores de feixe ajustam o tamanho e a forma do campo de raios $X$ que emergem a partir da janela do tubo de raios $X$. $O$ conjunto típico de um dispositivo limitador de feixe é ligado à cúpula de proteção radiológica na posição da janela de saida do tubo de raios $X$ com uma junta giratória. São utilizadas placas paralelas opostas ajustáveis para definir o campo de raios $X$.

No gabinete do dispositivo limitador de feixe, um feixe de luz refletido por um espelho, com ângulo de 45 graus, limita o feixe de raio $X$, desta forma a limitação do campo de raios $X$ é identificado pelas sombras das placas paralelas do dispositivo limitador de feixe, Figura $26^{[23]}$.

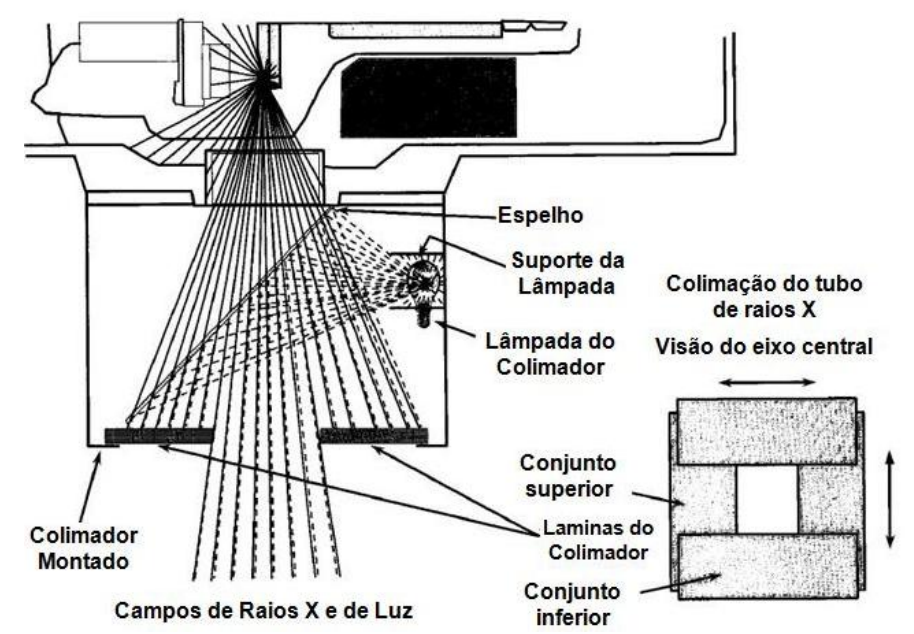

Figura 26 - Dispositivo limitador de feixe

\subsection{Geradores Monofásicos e Trifásicos e de potencial constante}

Existem vários projetos de circuitos geradores em uso, sendo os principais o monofásico, o trifásico, o de potencial constante e os geradores com inversores de média/alta freqüência.Todos utilizam transformadores elevadores para gerar a alta-tensão, transformadores abaixadores para energizar o filamento e circuitos retificadores para garantir a polaridade elétrica adequada no tubo de raios $X$. 


\subsubsection{Gerador de raios x monofásico}

O gerador de raios $X$ monofásico utiliza uma rede de alimentação elétrica monofásica (por exemplo, $220 \mathrm{~V}, 50 \mathrm{~A}$ ), e produz tanto formas de onda de um pulso ou de dois pulsos, dependendo dos circuitos de alta-tensão do retificador.

A Figura 27 mostra um diagrama dos componentes básicos de um circuito de um gerador monofásico e de dois pulsos (onda completa retificada). A ponte retificadora direciona o fluxo de elétrons de modo que os elétrons emergem sempre do cátodo para o ânodo.

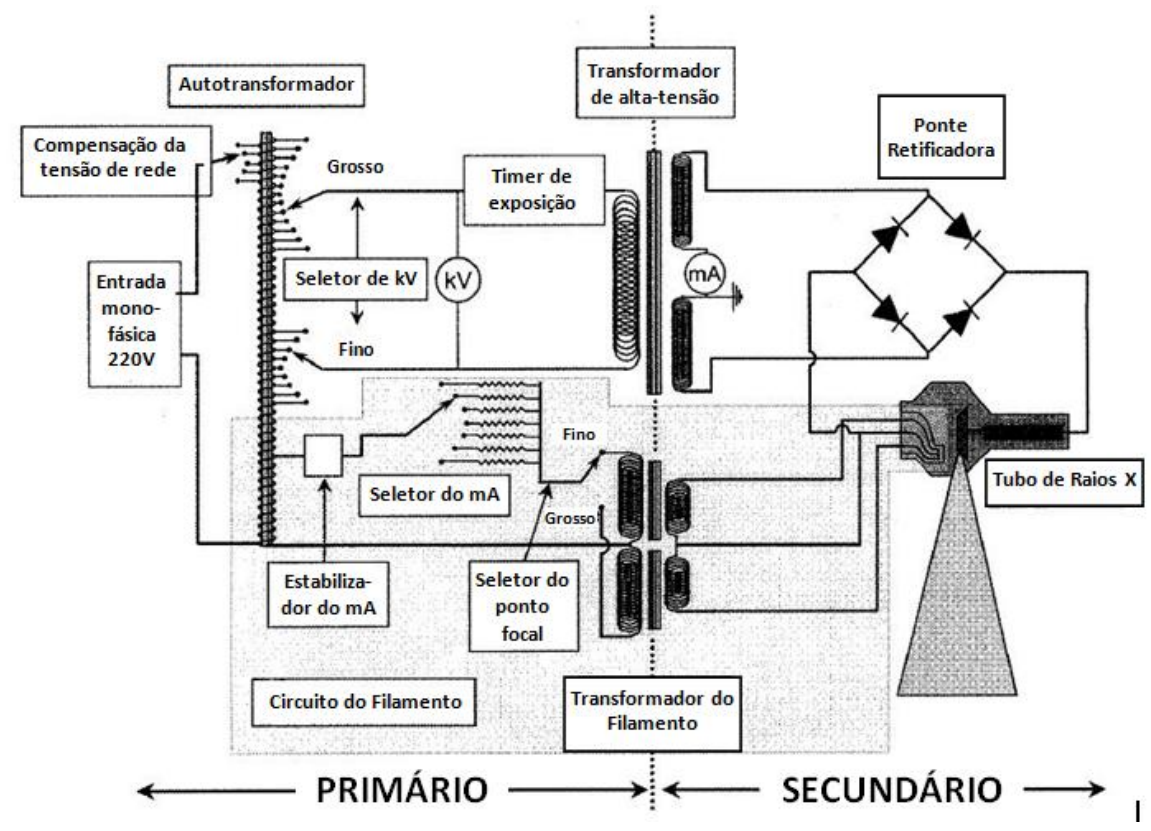

Figura 27 - O diagrama de um circuito monofásico de onda completa ${ }^{[23]}$.

A Figura 28 ilustra as formas de onda de tensão e de corrente produzida por este circuito.

O tempo mínimo de exposição (o tempo de um pulso) é normalmente limitado a intervalos de 1/120 segundo (8 ms). A terminação simples do circuito ocorre quando a tensão passa por zero, momento no qual os contatos dos interruptores podem ser abertos facilmente. 
Os temporizadores de exposição dos raios X que são calibrados em múltiplos de 1/120 segundo (por exemplo, 1/20 segundo, 1/10 de segundo, 1/5 segundos) indicam um gerador monofásico. A corrente do tubo de raios $X$ para uma corrente de filamento específica não é linear abaixo de $40 \mathrm{kV}$ devido ao efeito de carga espacial, Figura 28 (inferior esquerdo).

A capacitância do cabo, armazena e posteriormente libera a carga nos cabos de alta-tensão, alisa a variação na tensão, como mostrado na parte inferior do gráfico da direita da Figura $28^{[23]}$.
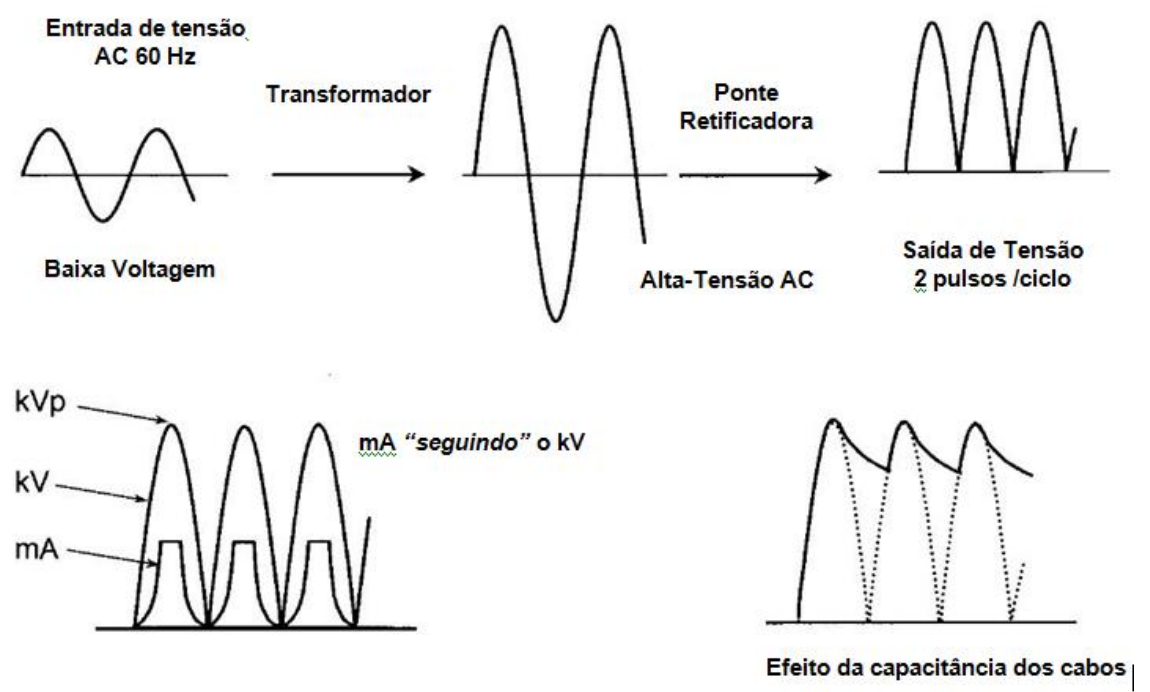

Figura 28 - Formas de onda de tensão e de corrente ${ }^{[23]}$.

\subsubsection{Geradores de Raios X trifásicos}

Os geradores de raios $X$ trifásicos utilizam uma fonte de alimentação trifásica de corrente alternada, Figura 29, cada um com uma única fase e forma de onda orientada de um terço de um ciclo (120 graus), em relação as outras duas fases (isto é, em 0, 120 e 240 graus). São utilizados três diferentes transformadores de alta-tensão ligados na configuração "triângulo" ou "delta". 


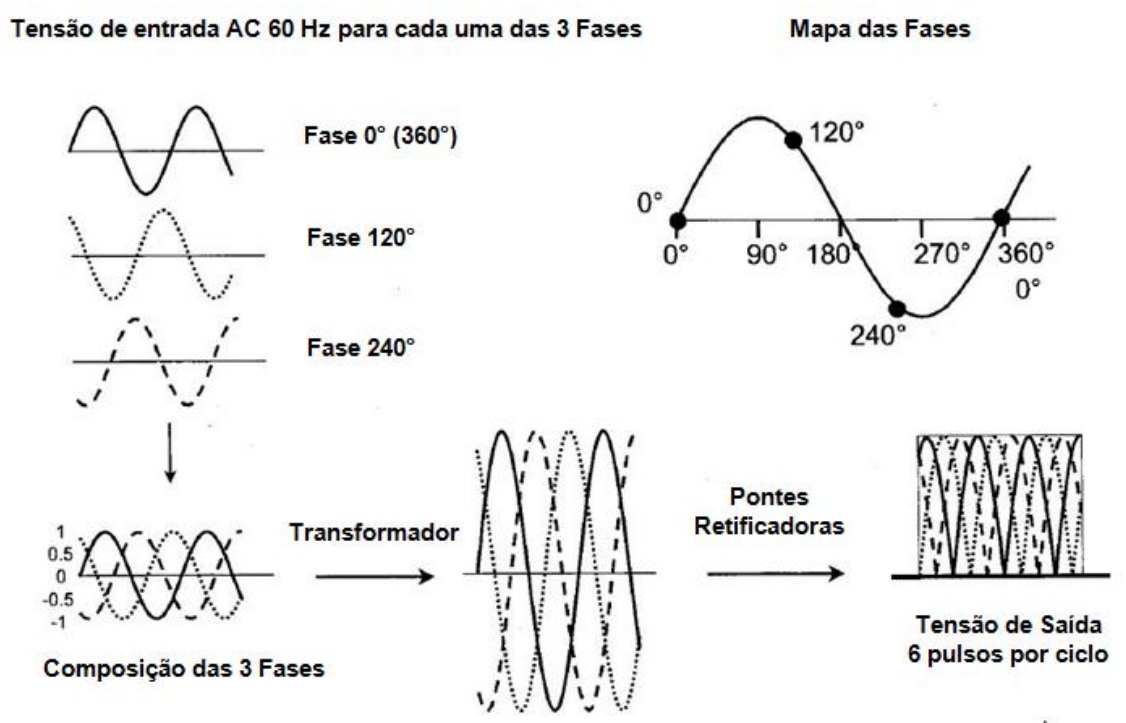

Figura 29 - Formas de onda do gerador de raios X trifásico

As três fases da fonte de tensão da rede de alimentação elétrica é composta por três formas de onda de tensão independentes separadas por incrementos de 120 graus por fase (superior). A tensão trifásica é transformada e corrigida no circuito de alta-tensão para fornecer uma corrente quase constante (corrente continua) com tensão de seis pulsos por ciclo, Figura $29^{[23]}$.

A ponte retificadora no lado da alta-tensão de cada circuito produz dois pulsos por ciclo para cada linha, resultando em seis pulsos por ciclo. Adicionando outro grupo de três transformadores em uma configuração do transformador em "estrela" e ponte retificadoras adicionais fornecem uma duplicação do número de pulsos ou 12 pulsos por ciclo ${ }^{\text {[23]. }}$

Na Figura 30 é ilustrado um circuito simplificado para gerador trifásico de seis pulsos. Uma rede de alimentação trifasica é conectada ao enrolamento primário do transformador, onde cada enrolamento pode ser considerado um transformador independente (configuração em triângulo ou delta). A ponte retificadora produz o sinal de saida de alta-tensão em corrente contínua ${ }^{[23]}$. 


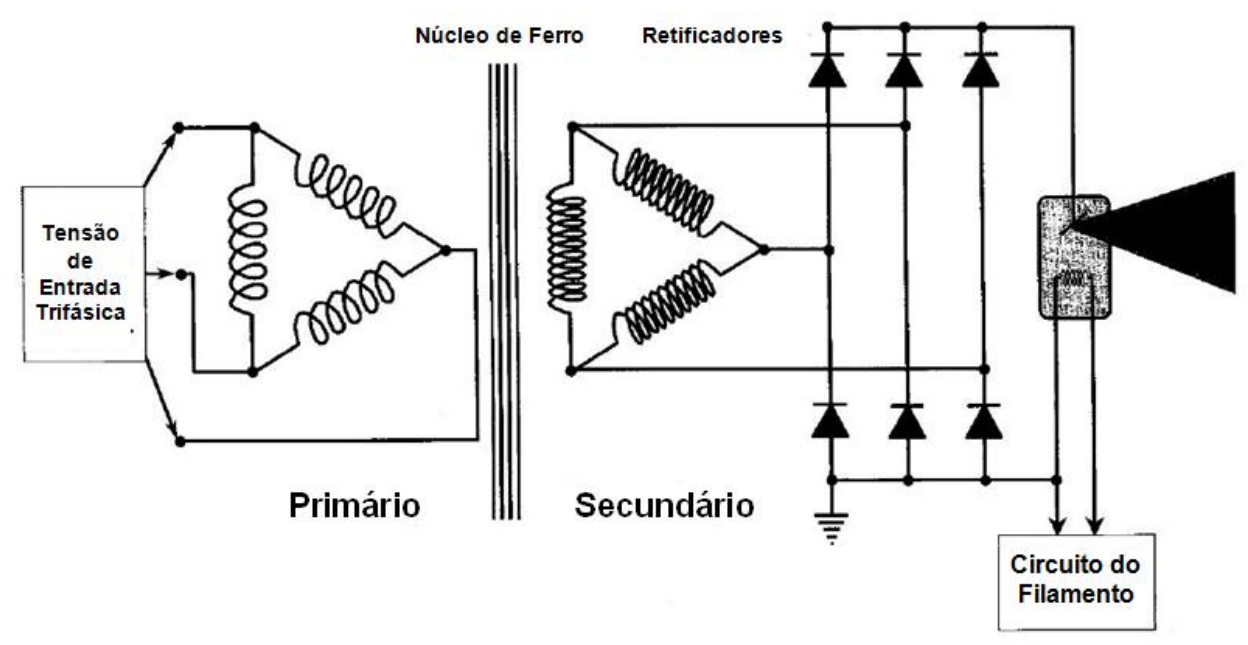

Figura 30 - Circuito simplificado para gerador trifásico de seis pulsos

\subsubsection{Gerador de potencial constante}

Um gerador de potencial constante fornece uma tensão quase constante ao tubo de raios $X$. Isto é conseguido com um transformador trifásico e circuito retificador fornecendo uma tensão máxima elevada (por exemplo, $150 \mathrm{kVp}$ ) para dois tubos de elétrons de alta-tensão de (triodos, tetrodos, ou pêntodos) ligados em linha no lado do cátodo e no lado do ânodo do tubo de raios $X$.

Estes tubos de elétrons controlam tanto a duração da exposição (chaveando a tensão de tubo em ligado e desligado com uma precisão de aproximadamente $20 \mathrm{f}$.Isec) e a magnitude da alta-tensão no circuito secundário (com capacidade de ajuste de 20 - a 50-f.Isec).

Um circuito comparador de alta-tensão mede a diferença entre o $\mathrm{kVp}$ desejado (set) no console de controle e o kVp real sobre o circuito de altatensão e ajusta a grade de eletrodos (e, portanto, a corrente e a e diferença de potencial) dos tubos de elétrons.

Esse feedback de circuito fechado garante um ajuste extremamente rápido do $\mathrm{kVp}$ e $\mathrm{mA}$ com tensão praticamente constante através do tubo de raios $X$. 
O tempo de exposição rápido que permite taxas de 500 pulsos por segundo ou mais. No entanto, o custo do hardware elevado, despesas operacionais e exigências de espaço são grandes desvantagens ${ }^{[23]}$.

\subsubsection{Gerador com inversor de alta frequência}

O gerador com inversor de alta freqüência é a escolha "estado da arte" contemporânea para sistemas de diagnóstico de raios X. Seu nome descreve sua função, segundo a qual uma forma de onda de alta freqüência alternada (até $50.000 \mathrm{~Hz}$ ) é usada para uma transformação eficaz de baixa para alta-tensão.

A retificação e filtração posterior produzem uma tensão de saída quase constante. Estas etapas de conversão são ilustradas na Figura 31. A freqüência de operação do gerador é variável, dependendo principalmente do ajuste da tensão $(\mathrm{kVp})$, mas também sobre a corrente $(\mathrm{mA})$ e as características de freqüência-tensão do transformador.

- Existem várias vantagens do gerador com inversor de alta freqüência:

- Pode ser utilizada tensão monofásica ou trifásica;

- Circuito fechado com feedback e regulação dos circuitos que garantem que os valores de corrente $(\mathrm{mA})$ e tensão $(\mathrm{kVp})$ sejam reprodutíveis e precisos;

- A variação na a tensão aplicada ao tubo de raios $X$ é semelhante ao de um gerador trifásico;

- Transformadores que operam a altas freqüências são mais eficientes, mais compactos e sua fabricação é menos onerosa, e

- O Design modular e compacto torna a localização dos equipamentos e reparos mais fáceis. 
Em um gerador com inversor de alta freqüência, uma rede monofásica ou trifásica é retificada e filtrada para criar uma forma de onda de corrente continua (DC). Um circuito inversor produz uma onda quadrada de alta freqüência como entrada para o transformador de alta tensão. A retificação e filtração fornecem a onda de saída de alta-tensão resultante com propriedades semelhantes às de um sistema trifásico, Figura 31.

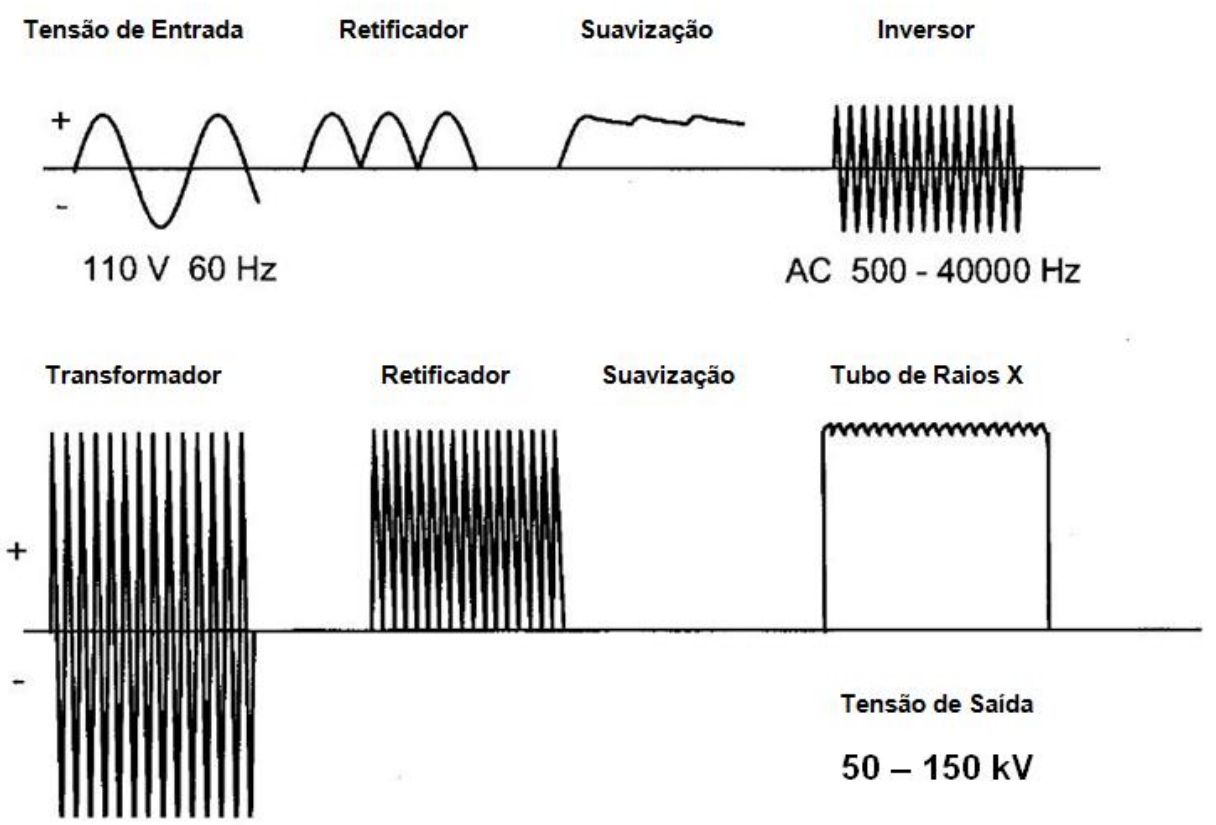

Figura 31 - Forma de onda de saída do gerador com inversor de alta frequência

A Figura 32 ilustra os componentes modulares do gerador de alta freqüência, mostrando o feedback dos sinais que fornecem excelente estabilidade da tensão de pico do tubo (kVp) e da corrente do tubo (mA). As linhas sólidas descrevem o circuito de baixa tensão, linhas tracejadas mostram o circuito de alta-tensão e as linhas pontilhadas mostram sinais de feedback de baixa tensão dos circuitos de medição ( $k \vee p$ e $m A$ ). A diferença de potencial através do tubo de raios $X$ é determinada pela carga entregue pelo circuito transformador e armazenada nos capacitores de alta-tensão ${ }^{\text {[23] }}$. 
Em seguida, um circuito inversor cria a forma de onda de corrente alternada de alta freqüência. Esta corrente alternada supre o transformador de alta-tensão e cria uma forma de onda de alta-tensão fixa e baixa corrente de maneira correspondente.

A retificação e filtração da forma de onda é realizada por dois capacitores de alta-tensão no circuito secundário, sombreada na Figura 32. Estes capacitores produzem uma tensão pelo tubo de raios $X$ que depende da carga acumulada, descrito pela relação $V=Q L C$, onde $V$ é a tensão (volts), QLC a carga (coulombs), e C é a capacitância (farads).

Durante a exposição de raios $\mathrm{X}$, os circuitos de feedback monitoram e corrigem a tensão e a corrente do tubo de raios $X$ em função de flutuações.

Para o ajuste da tensão ( $k \bigvee p)$, um comparador/oscilador de tensão mede a diferença entre a tensão de referência (um valor calibrado proporcional à $k V p$ solicitado) e a tensão ( $k \bigvee p)$ real medido através do tubo por um divisor de tensão (o circuito do kV). São gerados pulsos de disparo (trigger) pelo circuito de comparação que produz uma frequência que é proporcional à diferença de tensão entre o sinal de referência e o sinal medido.

A grande discrepância nos resultados da comparação de sinais produz pulsos de disparo em alta frequencia (trigger), enquanto que a ausência de diferença produz poucos ou nenhum pulso de disparo (trigger).

Para cada pulso de disparo, o circuito inversor DC/AC produz um pulso de saída correspondente, que é posteriormente convertido em um pulso de saída de alta-tensão pelo transformador. Os capacitores de alta-tensão armazenam a carga e aumenta a diferença de potencial através do tubo de raios $X$. 
Quando o potencial do tubo de raios $X$ atinge o valor desejado, a taxa de saída de pulso do circuito de comparação se estabelece para um valor aproximadamente constante, recarregando apenas os capacitores de altatensão quando a tensão do tubo de raios $X$ cai abaixo de um limite predeterminado.

O pulso de feedback (freqüência do gerador) depende da corrente do tubo (mA), já que os capacitores de alta-tensão se descarregam mais rapidamente maior $\mathrm{mA}$, acionando desta forma, o circuito comparador do kVp.

Em função da regulação de tensão em circuito fechado, não são necessários autotransformadores para seleção de kVp e para a compensação da entrada de tensão de rede, ao contrário de outros tipos de gerador.

A corrente $(\mathrm{mA})$ é regulada de maneira análoga à tensão $(\mathrm{kVp})$, com um circuito resistivo (shunt) que realiza a medição do $\mathrm{mA}$ real (a tensão sobre um resistor é proporcional à corrente) e a compara com uma tensão de referência. Se a corrente $(\mathrm{mA})$ é muito baixa, o comparador/oscilador de tensão aumenta a freqüência de disparo, aumentando a potencia do filamento elevando a sua temperatura e aumentando a emissão termiônica de elétrons.

O circuito de realimentação de circuito fechado elimina a necessidade de circuitos de compensação de carga e corrige automaticamente os efeitos de envelhecimento dos filamentos.

O gerador com inversor de alta freqüência é o sistema preferido, mas, algumas aplicações (por exemplo, aqueles que necessitam de energia extremamente alta, mudança de tensão $(k \bigvee p)$ extremamente rápida ou tempo de exposição menores que millisegundos). Em apenas casos raros o gerador de potencial constante é a melhor escolha ${ }^{[23]}$. 


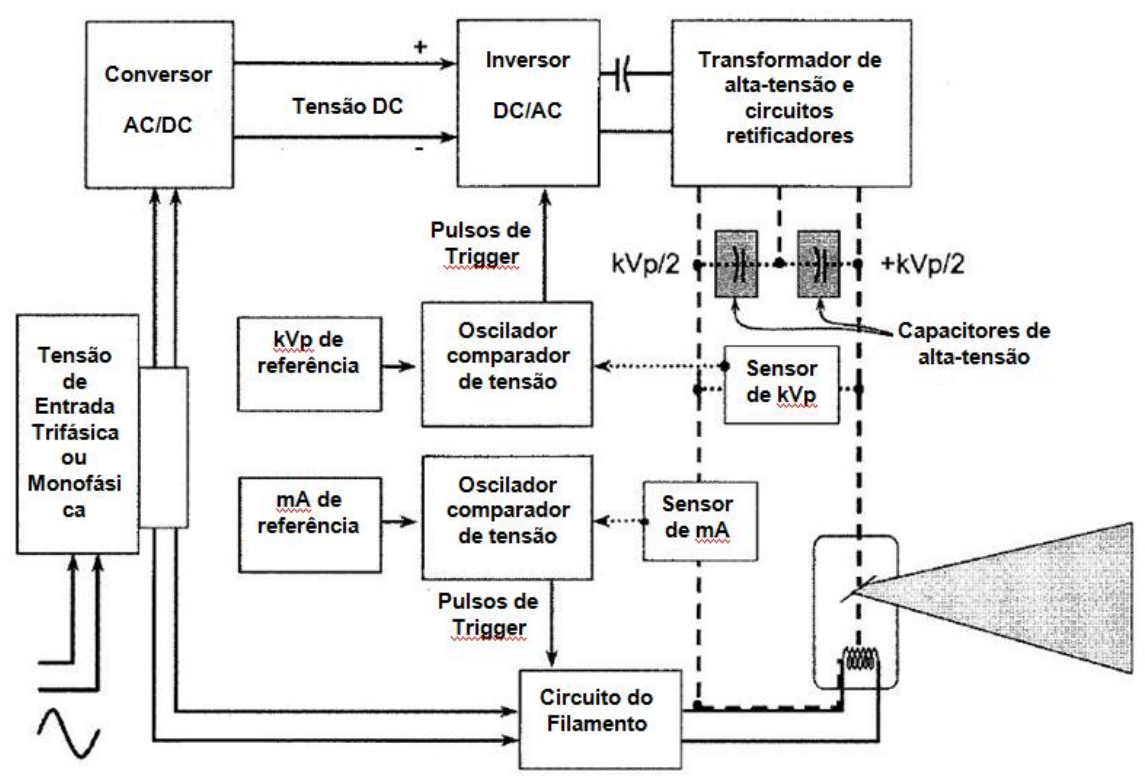

Figura 32 - Componentes modulares do gerador de alta freqüência

\subsection{Proteção Radiológica}

Proteção radiológica pode ser definida como um conjunto de ações para proteger profissionais ocupacionalmente expostos, pacientes e público em geral, da exposição desnecessária à radiação ionizante. A exposição desnecessária é qualquer exposição à radiação ionizante que não traz benefício ao paciente em termos de informação diagnóstica obtida ${ }^{[34]}$.

Em junho de 1998 foi publicada no Brasil a Portaria SVS-MS $453^{\text {[31] }}$ que estabelece as diretrizes básicas de proteção radiológica em radiodiagnóstico médico e odontológico. Ela é regida por quatro princípios básicos de proteção radiológica. São eles:

- Justificação da prática e das exposições médicas individuais;

- Otimização da proteção radiológica;

- Limitação de doses individuais;

- Prevenção de acidentes.

O primeiro princípio estabelece que nenhuma prática deve ser autorizada a menos que produza benefício suficiente para o indivíduo exposto ou para a sociedade, de modo a compensar o detrimento que possa ser causado. 
Este princípio deve ser aplicado considerando-se que a totalidade dos benefícios potenciais em matéria de diagnóstico ou terapêutica que decorram da exposição médica é maior que o detrimento que possa ser causado pela radiação ao indivíduo. Além disso, deve-se considerar a eficácia, os benefícios e os riscos de técnicas alternativas disponíveis com o mesmo objetivo, mas que envolvam menos ou nenhuma exposição a radiações ionizantes.

O segundo princípio da proteção radiológica é o da otimização. Tal princípio estabelece que as instalações e as práticas devem ser planejadas, implantadas e executadas de modo que a magnitude das doses individuais, o número de pessoas expostas e a probabilidade de exposições acidentais sejam tão baixos quanto razoavelmente exeqüíveis (Princípio ALARA - As Low As Reasonably Achievable), levando-se em conta fatores sociais e econômicos, além das restrições de dose aplicáveis.

O princípio da limitação de doses individuais estabelece que os limites de dose, tanto para trabalhadores com radiação quanto para indivíduos do público, devem ser respeitados. Estes limites são valores de dose efetiva ou de dose equivalente, estabelecidos para exposição ocupacional e exposição do público, decorrentes de práticas controladas, cujas magnitudes não devem ser excedidas.

No quarto e último princípio, prevenção de acidentes, as instalações e os equipamentos devem ser projetados de tal forma a minimizar a probabilidade de ocorrência de acidentes (exposições potenciais). Além disso, deve-se desenvolver os meios e implementar as ações necessárias para minimizar a contribuição de erros humanos que levem à ocorrência de exposições acidentais.

A minimização da exposição desnecessária pode ser obtida fazendo-se uso de três fatores principais: tempo, distância e blindagem. 0 tempo e a dose são diretamente proporcionais, ou seja, quanto mais o profissional ocupacionalmente exposto e o paciente ficarem expostos a uma fonte de radiação ionizante, maior será a dose. 
A distância é o fator de proteção radiológica mais eficiente. Neste caso, quando a distância entre a fonte de radiação e o indivíduo aumenta, a dose diminui pelo quadrado da razão da distância inicial pela nova distância da fonte (lei do inverso do quadrado da distância, apresentada na Figura 33).

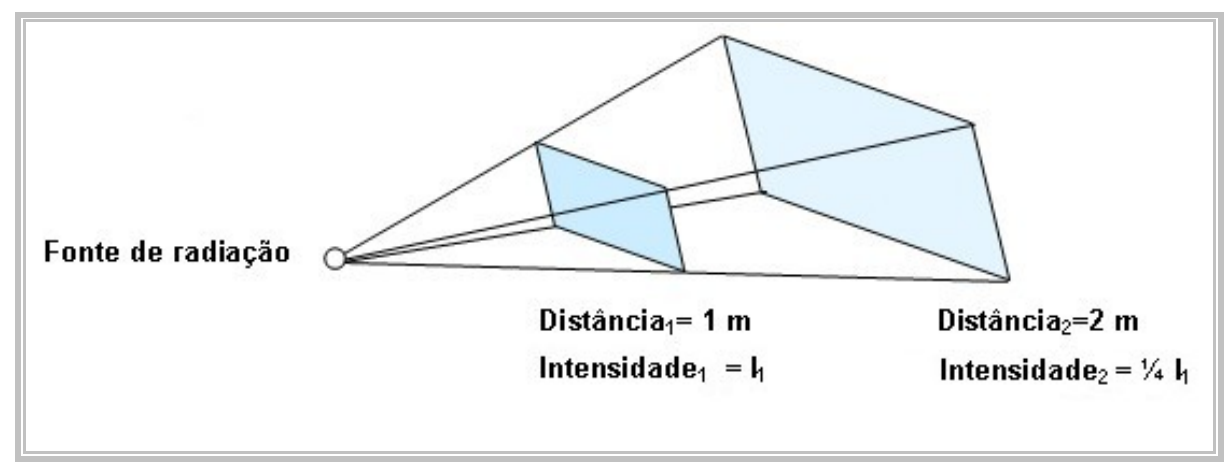

Figura 33- Ilustração da lei do inverso do quadrado da distância

O terceiro fator utilizado para minimizar a dose é a blindagem. As blindagens consistem em materiais estruturais, como portas e visores plumbíferos, ou dispositivos como barreiras móveis, aventais de proteção, óculos e blindagens de ovário, confeccionados com material radio-opaco.

As blindagens são confeccionadas com materiais compostos por elementos de alto número atômico. Na proteção radiológica o chumbo é o material de referência, pois o seu alto número atômico ( $Z=82)$ garante a absorção de grande parte dos fótons espalhados $\left.{ }^{[35} 36\right]$.

\subsection{Incerteza de Medição}

Quando se relata o resultado de medição de uma grandeza física, é obrigatório que seja fornecida alguma indicação quantitativa da qualidade do resultado, de forma tal que aqueles que o utilizam possam avaliar sua confiabilidade. Sem essa indicação, resultados de medição não podem ser comparados, seja entre eles ou com valores de referência fornecidos numa especificação ou numa norma. É, portanto, necessário que haja um procedimento prontamente implementado, facilmente compreendido e de aceitação geral para caracterizar a qualidade de um resultado de uma medição, isto é, para avaliar e expressar sua incerteza ${ }^{[37]}$. 
De acordo com o Guia para a Expressão da Incerteza de Medição (GUM) ${ }^{[37]}$, incerteza de medição é um "parâmetro, associado ao resultado de uma medição, que caracteriza a dispersão dos valores que podem ser razoavelmente atribuídos ao mensurando".

Em outras palavras, o termo incerteza de medição significa que, para um dado mensurando e um dado resultado, não há um único valor, mas sim, um infinito número de valores dispersos em torno do resultado, que são consistentes com todas as observações e dados e conhecimentos sobre o mundo físico, e que podem ter diferentes graus de credibilidade atribuídos ao mensurando.

Embora as incertezas avaliadas sejam pequenas, não se pode afirmar que o erro no resultado da medição é pequeno, uma vez que ao se determinar uma correção, por exemplo, um efeito sistemático pode ter passado despercebido, por não ser reconhecido ${ }^{[37]}$.

Os componentes da incerteza são agrupados em duas categorias baseadas no seu método de avaliação: A e B. A primeira categoria (incerteza do tipo $A$, representada por $u_{A}$ ) está relacionada com métodos de avaliação da incerteza pela análise estatística de séries de observações, enquanto que a segunda (incerteza do tipo $\mathrm{B}$, representada por $u_{B}$ ) está relacionada a métodos de avaliação da incerteza por outros meios que não a análise estatística de série de observações, ou seja, informações contidas nos certificados de calibração, especificação dos instrumentos e padrões, dados técnicos dos fabricantes, livros e manuais técnicos e estimativas baseadas na experiência $[37,38]$.

Sendo a incerteza padrão $(u)$ a incerteza do resultado de uma medição expressa como um desvio padrão, a incerteza padrão combinada é a incerteza padrão do resultado de uma medição, quando este resultado é obtido por meio de valores de várias outras grandezas. Ela é igual à raiz quadrada positiva de uma soma de termos, que constituem as variâncias ou covariâncias destas outras grandezas, ponderadas de acordo com quanto o resultado da medição varia com mudanças nestas grandezas ${ }^{[37]}$. 
A incerteza padrão combinada, representada por $u_{C}$, para grandezas não correlacionadas é obtida pela equação abaixo ${ }^{[16]}$.

$$
u_{C}^{2}(y)=\sum_{i=1}^{N}\left[\frac{\partial f}{\partial x_{i}}\right]^{2} \cdot u^{2}\left(x_{i}\right)
$$

onde: $u\left(x_{i}\right)$ é a incerteza padrão

$$
\left[\frac{\partial f}{\partial x_{i}}\right] \text { é o coeficiente de sensibilidade }
$$

Quando as grandezas apresentam dependência entre si, diz-se que há uma correlação entre elas; a correlação pode aumentar ou diminuir o valor da incerteza associada a esta grandeza. No caso de um mesmo instrumento utilizado para a medição de dois ou mais parâmetros, a correlação é gerada devido ao efeito sistemático intrínseco a este instrumento de medição ${ }^{[39]}$. Assim, a incerteza padrão combinada para grandezas correlacionadas é dada pela equação abaixo ${ }^{[17]}$.

$$
u_{C}^{2}(y)=\sum_{i=1}^{N}\left[\frac{\partial f}{\partial x_{i}}\right]^{2} \cdot u^{2}\left(x_{i}\right)+2 \sum_{i=1}^{N-1} \sum_{j=i+1}^{N} \frac{\partial f}{\partial x_{i}} \frac{\partial f}{\partial x_{j}} \cdot u\left(x_{i}\right) \cdot u\left(x_{j}\right) \cdot r\left(x_{i}, x_{j}\right)
$$

onde: $u\left(x_{i}\right), \mathrm{u}\left(x_{j}\right)$ são as incertezas padrão das grandezas $x_{i}$ e $x_{j}$;]

$$
\left[\frac{\partial f}{\partial x_{i}}\right] \text { e }\left[\frac{\partial f}{\partial x_{j}}\right] \text { são os coeficientes de sensibilidade; }
$$

$$
r\left(x_{i}, x_{j}\right) \text { é o coeficiente de correlação } \Rightarrow-1<r\left(x_{i}, x_{j}\right) \leq+1
$$

A incerteza expandida, representada por $U_{95}$, é a grandeza que define um intervalo em torno do resultado de uma medição com o qual se espera abranger uma grande fração da distribuição dos valores que possam ser razoavelmente atribuídos ao mensurando. Ela é obtida por meio da equação ${ }^{[18]}$, onde $k$ é o fator de abrangência. $O$ fator de abrangência $k$ é um fator numérico que, tipicamente, está na faixa de 2 a $3^{[37]}$.

$$
U_{95}=u_{C} \cdot k
$$


A metodologia utilizada para o cálculo das incertezas na determinação da espessura equivalente de atenuação deste trabalho foi a proposta pelo GUM ${ }^{[37]}$.

No procedimento para a avaliação e a expressão da incerteza proposto inicialmente deve-se equacionar as fontes de incerteza modelando a medição. Em seguida, devem ser obtidas as incertezas do tipo B por meio das informações apresentadas nos certificados de calibração e nos manuais dos equipamentos utilizados durante a medição.

Então, as incertezas do tipo A e B são dispostas juntas, geralmente utilizando-se uma planilha de cálculo, de forma que os coeficientes de sensibilidade e a incerteza padrão possam ser avaliados e a incerteza combinada seja calculada.

Com esses resultados, calcula-se o número de graus de liberdade efetivo ( $\nu_{\text {eff }}$ ) definido por Welch-Satterthwaite de acordo com a equação abaixo [19]

$$
v_{e f f}=\frac{u_{C}^{4}}{\sum_{i}^{n} \frac{u_{i}^{4}}{v_{i}}}
$$

onde: $u_{C}$ é a incerteza padrão combinada

$u_{i}$ é a incerteza padrão

$\nu_{i}$ é o número de graus de liberdade

Após a determinação do $\nu_{\text {eff, }}$ procura-se numa tabela de coeficientes de Student, o coeficiente que será adotado como fator de abrangência $(k)$ correspondente a um nível de confiança de 95,45\%. Finalmente, multiplica-se o valor de $k$ por $u_{C}$ obtendo-se a incerteza expandida $\left(U_{C}\right)$. 


\subsection{LabVIEW}

A palavra LabVIEW TM é uma sigla que significa "Bancada de Engenharia de Instrumentação Virtual", numa tradução direta.

O LabVIEW é uma linguagem de programação gráfica que utiliza ícones, em vez de linhas de texto, para criar aplicações. Em contraste às linguagens de programação baseadas em texto, em que instruções determinam a execução do programa, o LabVIEW utiliza programação baseada em fluxo de dados, onde o fluxo dos dados determina a execução. O Fluxo dos dados é a espinha dorsal do ambiente de programação que permite agregar outros módulos de aplicações mais específicas para trabalhos que envolvem: imagens, controle de motores, aquisição e armazenamento de dados, controle de instrumentos, internet, sistemas microcontrolados, FPGA, apresentação de dados em 3D, etc.

No LabVIEW, a interface de usuário é construída utilizando um conjunto de ferramentas e objetos. A interface de usuário é conhecida como Painel frontal. O código é adicionado utilizando representações gráficas de funções para controlar os objetos do painel frontal. O diagrama de blocos contém esse código. Sob certos aspectos, o diagrama de blocos assemelha-se a um fluxograma.

O LabVIEW está totalmente integrado para comunicação com diversos hardwares, como GPIB, VXI, PXI, RS-232, RS-485 e dispositivos DAQ plug-in.

O LabVIEW também possui recursos internos para conectar a aplicação à Internet, utilizando o LabVIEW Web Server e aplicativos como ActiveX e redes TCP/IP. Utilizando esta plataforma, é possível criar aplicações de teste e medição, aquisição de dados, controle de instrumento, registro de dados, análise de medição e geração de relatório.

É possível criar também executáveis e bibliotecas compartilhadas, como DLLs, já que o LabVIEW é um compilador real de 32 bits. 
Os programas em LabVIEW são chamados de instrumentos virtuais (VIs_-Virtual Instruments). Os VIs contêm três componentes principais:

- o painel frontal;

- o diagrama de bloco, e

- o painel de ícones e conectores.

O painel frontal é a interface com o usuário. A Figura 34 exibe um exemplo de painel frontal.

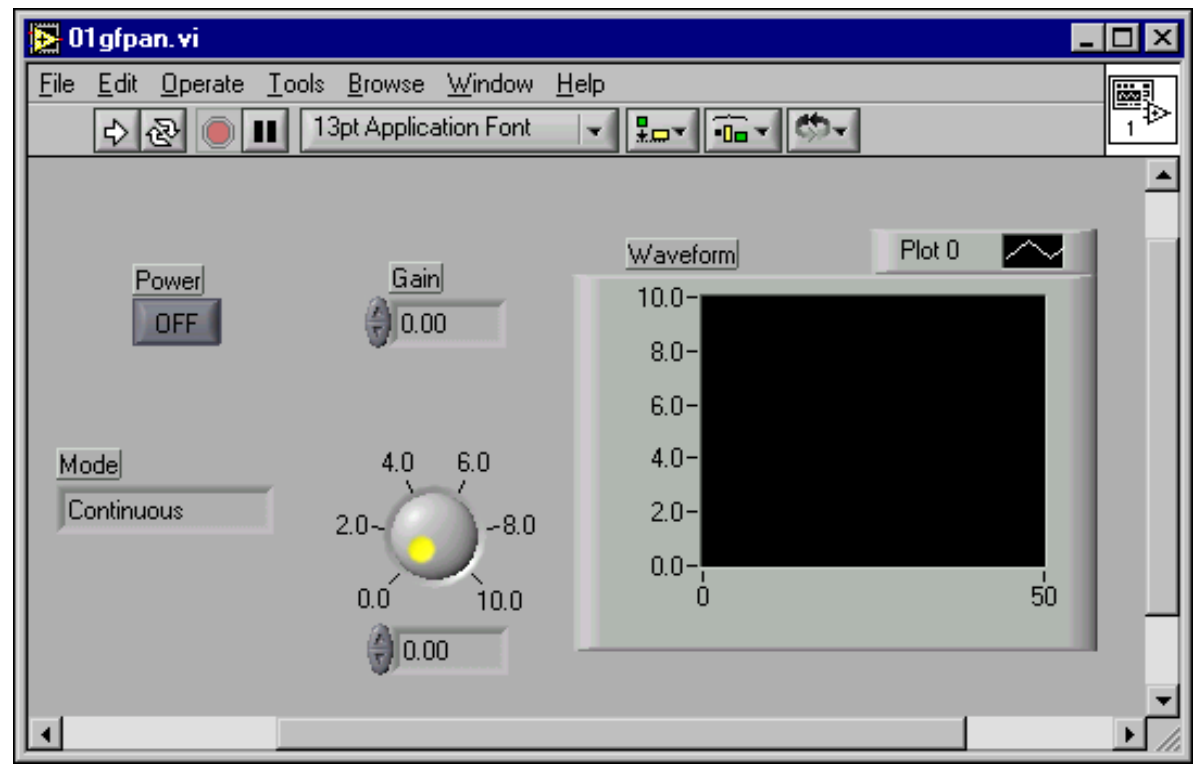

Figura 34 - O painel frontal do LabVIEW

O painel frontal é montado com controles e indicadores, que são os terminais interativos de entrada e saída do VI, respectivamente.

- Controles são botões, botões de pressão, dials e outros dispositivos de entrada. Indicadores são gráficos, LEDs e outros displays.

- Os controles simulam dispositivos de entrada de instrumentos e fornecem dados para o diagrama de blocos do VI.

- Os indicadores simulam dispositivos de saída de instrumentos e exibem os dados que o diagrama de bloco adquire ou gera. 
Após a montagem do painel frontal, utilizando representações gráficas de funções, o código para controlar os objetos do painel frontal é construído. O diagrama de blocos contém este código.

Os objetos do painel frontal aparecem como terminais, exibidos à esquerda, no diagrama de blocos. Um terminal do diagrama de blocos não pode ser excluído. O terminal desaparece somente após a exclusão de seu objeto correspondente do painel frontal. Os objetos do diagrama de bloco incluem terminais, subVIs, funções, constantes, estruturas e ligações, que transferem dados entre outros objetos do diagrama de blocos ${ }^{[40]}$.

A Figura 35 mostra um diagrama de blocos e seu painel frontal correspondente.

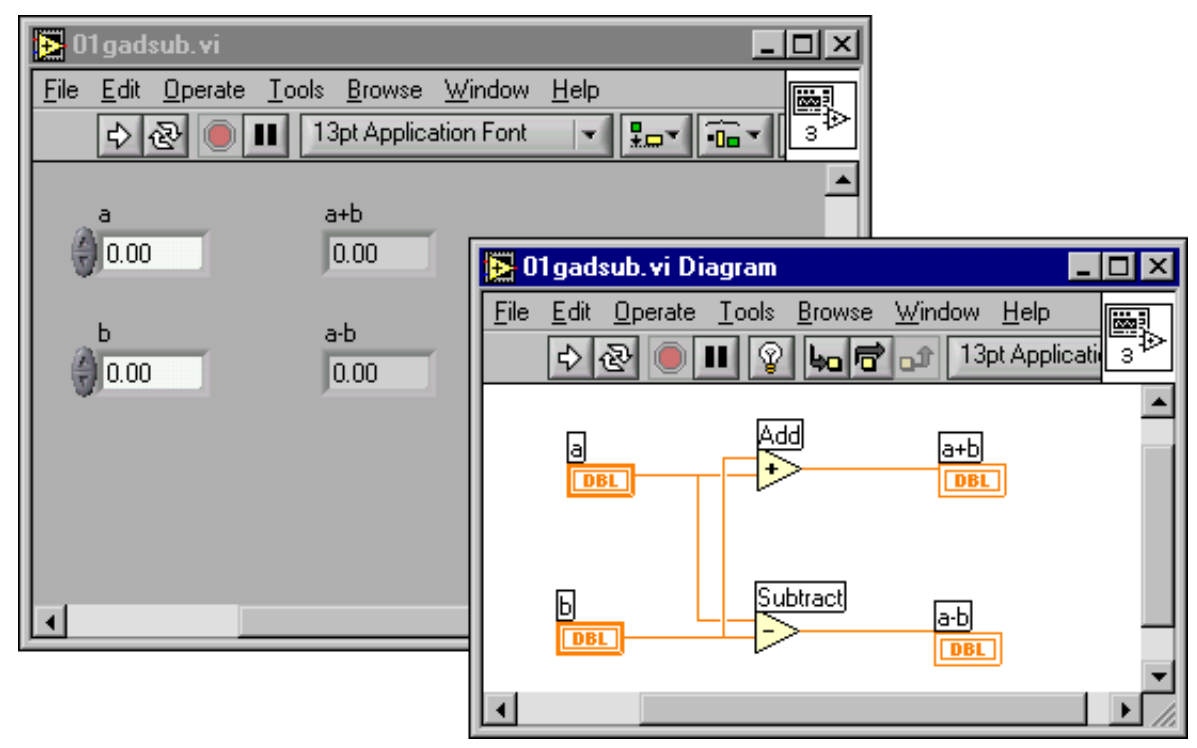

Figura 35 - Diagrama de blocos e painel do labVIEW

A vantagem do LabVIEW está na natureza hierárquica do VI. Após a criação de um VI, você pode utilizá-lo como um subVI no diagrama de bloco de um VI de alto nível. Não existe limite para a quantidade de níveis a hierarquia. A utilização de subVIs ajuda o gerenciamento de alterações e a depuração do diagrama de bloco rapidamente. 
À medida que os VIs são criados, percebe-se que uma determinada operação é executada com frequência, para facilitar o desenvolvimento existe a possibilidade de utilizar subVIs ou loops (ciclos) para executar essa operação de forma repetitiva, por exemplo, o diagrama de bloco da Figura 36 contém duas operações idênticas.

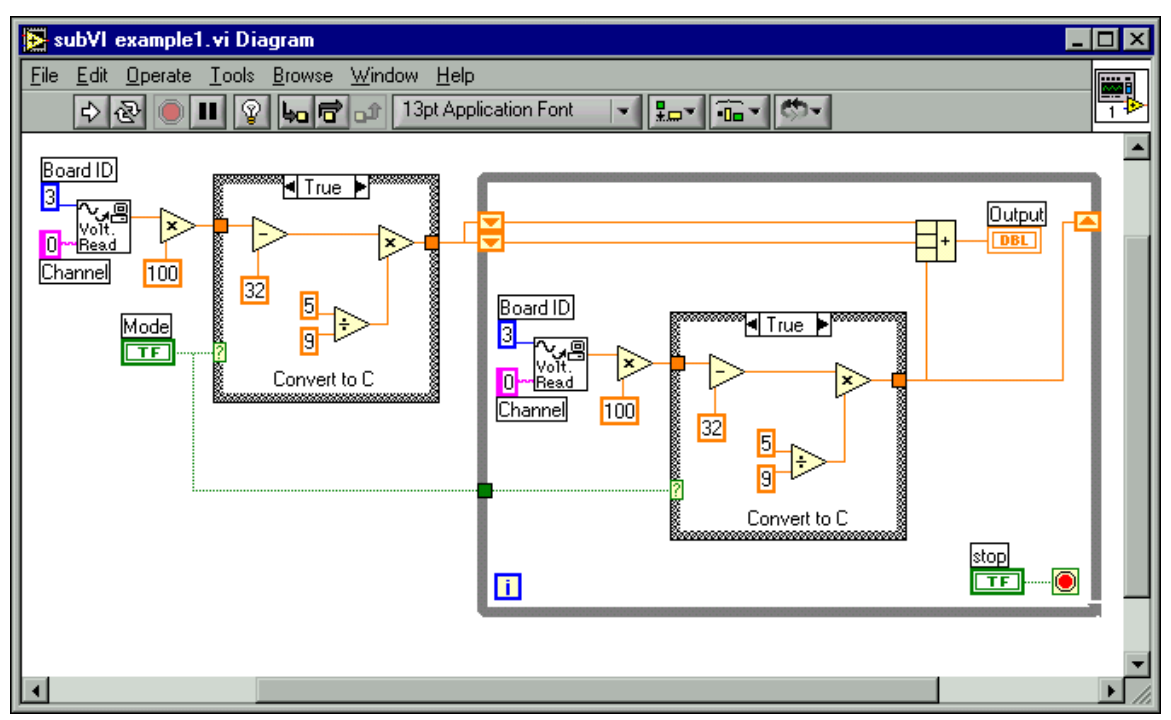

Figura 36 - Diagrama de blocos com duas funções idênticas

Uma questão importante sobre o LabVIEW é o fato de se tratar de um software utilizado em âmbito mundial por muitos engenheiros e cientistas para desenvolver sofisticados sistemas integrando software e hardware entre muitos fabricantes e possui uma rede aberta de usuários, organizados em muitas comunidades que compartilham códigos, dúvidas e outras informações gratuitamente pela internet ${ }^{[41]}$. 


\subsection{Questão ambiental}

O estudo e reaproveitamento de dispositivos eletrônicos são importantes, pois a organização não governamental Greenpeace estima de 20 a 50 milhões de toneladas de lixo eletrônico são geradas no mundo a cada ano. Ainda de acordo com a ONG, o chamado e-lixo (e-waste, em inglês) responde hoje por $5 \%$ de todo o lixo sólido do mundo, quantia similar à das embalagens plásticas. Com a diferença de que, quando descartados de maneira inadequada, os eletrônicos podem ser mais nocivos.

Esses equipamentos contêm centenas de diferentes materiais - um celular, de acordo com o Greenpeace, tem de 500 a 1 mil componentes diferentes. Na composição de muitos deles há metais pesados, como mercúrio, cádmio e chumbo, que podem poluir o ambiente e prejudicar a saúde das pessoas $^{[42]}$.

Os equipamentos eletrônicos, em geral, possuem em seus componentes diversas substâncias nocivas à saúde e ao meio ambiente tais como o chumbo, o mercúrio, o cádmio, o berílio, etc. O contato com esses elementos pode trazer complicações levando o ser vivo à morte. Caso esses materiais sejam dispersos no meio ambiente poluirão o solo, o lençol freático e o $\operatorname{ar}^{[43]}$.

Dentre os diversos elementos que podem ser encontrados em equipamentos eletrônicos, os sugeridos como mais comuns e seus efeitos aos seres humanos são os apresentados na Tabela 3.

Por exemplo, segundo a diretiva RoHS (Restriction of the Use of Certain Hazardous Substances in Electrical and Electronic Equipment), a liga de chumbo e estanho presente nas placas de circuito impresso para a soldagem de componentes, não deveria ser mais utilizada. Entretanto, continua sendo a liga mais utilizada para a soldagem de componentes eletrônicos, contendo $63 \%$ em massa de estanho e $37 \%$ em massa de chumbo. Verifica-se que esta liga, mesmo que usada em pequenas quantidades, é constituída por um dos metais que é veementemente restringido pela RoHS. 
Considerando que atualmente, muitos produtos eletrônicos contendo chumbo continuam sendo concebidos e produzidos em grande escala, sem considerar os requisitos da RoHS e WEEE (Waste Electrical and Electronic Equipment). Deste modo, como medida paliativa é imperativo o desenvolvimento de meios e medidas para se evitar o descarte destes ao meio ambiente ${ }^{[44]}$.

Tabela 3 - Lista de elementos e seus efeitos nos seres humanos

\begin{tabular}{|l|l|}
\hline \multicolumn{1}{|c|}{ ELEMENTO } & \multicolumn{1}{c|}{ EFEITOS } \\
\hline Arsênio & $\begin{array}{l}\text { Câncer (seios paranasais), doenças de pele, } \\
\text { prejudica o sistema nervoso }\end{array}$ \\
\hline Berílio & Causa câncer no pulmão \\
\hline Cádmio & $\begin{array}{l}\text { Câncer de pulmões e próstata, lesão nos } \\
\text { rins, danos aos ossos, causa } \\
\text { envenenamento }\end{array}$ \\
\hline Chumbo & $\begin{array}{l}\text { Saturnismo (cólicas abdominais, tremores, } \\
\text { fraqueza muscular, lesão renal e cerebral), } \\
\text { causa danos ao sistema nervoso e } \\
\text { sanguíneo }\end{array}$ \\
\hline Cobalto & $\begin{array}{l}\text { Fibrose muscular (endurecimento do pulmão) } \\
\text { que pode levar à morte }\end{array}$ \\
\hline Cromo & Asma (bronquite); câncer \\
\hline Mercúrio & $\begin{array}{l}\text { Intoxicação do sistema nervoso central, } \\
\text { causa danos ao fígado }\end{array}$ \\
\hline Níquel & Câncer de pulmão e seios paranasais \\
\hline Retardantes de chama bromados & $\begin{array}{l}\text { Causam desordem hormonais, nervosas e } \\
\text { reprodutivas }\end{array}$ \\
\hline
\end{tabular}

A questão ambiental estará presente neste trabalho por meio da utilização de dispositivos eletrônicos (drives de CD de computador) que seriam descartados por não realizarem mais a sua função, leitura de dados, porém os mesmos mantinham integras as suas funções eletromecânicas (saída e entrada das "gavetas do drive), funções estas que serão reaproveitadas no desenvolvimento do dispositivo de ensaio. 


\section{MATERIAIS E MÉTODOS}

\subsection{MATERIAIS}

\subsubsection{Instrumentos de medição}

Os equipamentos e instrumentos que foram utilizados nas medições, para a validação do dispositivo de ensaio e relacionados a seguir, possuem o nível de exatidão e calibração necessário para que os valores medidos fossem confiáveis permitindo a validação do dispositivo com os critérios metrológicos exigidos pela ACREDITAÇÃO do INMETRO da Seção Técnica de Ensaios em Equipamentos Eletromédicos do Instituto de Eletrotécnica e Energia da Universidade de São Paulo (STEEE - IEE/USP).

\subsubsection{Determinação das filtrações com equivalência em alumínio e da CSR}

Para as medições de kerma no ar para a determinação das filtrações com equivalência de qualidade em alumínio e da CSR, foi utilizado o medidor de parâmetros radiológicos modelo 9095 em conjunto com a câmara de ionização modelo 10x06-06 ambos fabricados pela Radcal co., especificados na Tabela 4.

Tabela 4 - Especificações do medidor de parâmetros radiológicos modelo 9095 e da câmara de Ionização modelo 10x6-06 ${ }^{[45]}$

\begin{tabular}{|c|c|}
\hline \multicolumn{2}{|r|}{ ESPECIFICAÇÕ̃ES } \\
\hline $\begin{array}{l}\text { Medidor de parâmetros radiológicos } \\
\text { modelo 9095- Radcal Co. }\end{array}$ & Dose - $\pm 4 \%, \pm 1$ dígito, $\pm 2 \times$ resolução \\
\hline \multirow[b]{4}{*}{$\begin{array}{l}\text { Câmara de Ionização modelo 10x6-06 - } \\
\text { Radcal Co. }\end{array}$} & Tempo - $\pm 0,1 \%, \pm 0,2 \mathrm{~ms}, \pm 1$ dígito \\
\hline & kV Diagnóstico - $1 \mathrm{kV} \pm$ ou $\pm 1 \%$, o que for maior \\
\hline & Reprodutibilidade - Dose/Taxa Dose: $1 \% \pm 1$ dígito \\
\hline & Taxa min: $2 \mathrm{mR} / \mathrm{s}-20 \mathrm{nG} / \mathrm{s}$ \\
\hline & Taxa máx: 17 R/s - 49 mGy/s \\
\hline & Dose máx: 59 kR - 516 Gy \\
\hline & $\begin{array}{l}\text { Precisão da Calibração: } \pm \text { 4\%, utilizando raios-X em 60kVp e 2,8 } \\
\text { mm AL de CSR }\end{array}$ \\
\hline & $\begin{array}{l}\text { Dependência energética: } \pm 5 \%, 30 \mathrm{keV} \text { até } 1,33 \mathrm{MeV} \text { (com material } \\
\text { build-up) }\end{array}$ \\
\hline
\end{tabular}




\subsubsection{Monitoração dos parâmetros de aplicação de carga}

Para o controle e monitoração dos parâmetros de aplicação de carga ( $\mathrm{kV}, \mathrm{mA}$ e Tempo), aplicados ao conjunto fonte de raios $\mathrm{X}$ pelo gerador de altatensão, foi utilizado um divisor de alta-tensão invasivo modelo Dynalyzer III fabricante Radcal Co USA, especificado na Tabela 5, garantindo desta forma que os valores de kerma no ar medidos pela câmara de ionização estivessem dentro de um limite de variação aceitável.

O divisor de alta-tensão consiste basicamente em uma malha resistiva capaz de operar em alta-tensão, não indutiva, montado em um reservatório com um meio isolante de alta-tensão que pode ser um gás ou óleo mineral. Este circuito divisor pode ser ativo ou passivo, ou seja, com ou sem compensação eletrônica e circuitos amplificadores integrados ao sistema. A vantagem do sistema ativo é que a resposta em frequência normalmente já é efetuada pelo circuito eletrônico, não sendo necessária a correção da informação de saída do divisor.

Em alguns casos, no emprego do circuito passivo, os resistores apresentam comportamento indutivo em determinadas faixas de frequência. Nestes casos são utilizados capacitores para alta-tensão em conjunto com a malha resistiva para compensação em frequência.

Tabela 5 - Especificações do Divisor de alta-tensão Dynalyzer IIIU [46]

\begin{tabular}{|l|l|}
\hline \multicolumn{2}{|c|}{ ESPECIFICAÇõES } \\
\hline Divisor de alta-tensão Dynalyzer IIIU Radcal Co. & \multirow{2}{*}{ Fabricante: Radcal Co. } \\
\hline & Modelo: Dynalyzer IIIU \\
\cline { 2 - 3 } & Precisão do kV: $( \pm 0,75 \mathrm{kV}+0,5 \%) 10 \mathrm{kV}$ a $150 \mathrm{kV}$ \\
\cline { 2 - 3 } & Corrente do Ânodo: $\pm 2 \%$ para $1 \mathrm{~mA}$ a 2 ampères \\
\cline { 2 - 3 } & Tempo de Exposição: $\pm(0,25 \mathrm{~ms}+0,5 \%)$ \\
\hline & Corrente do Filamento: $\pm\left(0.05^{\mathrm{a}}+0,7 \%\right)$ \\
\hline
\end{tabular}




\subsubsection{Distância e posicionamento}

Para o posicionamento correto dos itens que compõem o dispositivo de ensaio foram utilizados o Medidor de nível digital ( 0 a $\left.360^{\circ}\right)$ fabricante SmartTool, para o posicionamento horizontal do conjunto fonte de radiação $\mathrm{Xe}$ do sistema trocador de filtros e uma Régua $(0$ a $1000 \mathrm{~mm}$ ) utilizada para o ajuste das distâncias entre o ponto focal do conjunto-fonte de radiação $X$ e 0 sistema trocador de filtros, a distância entre o ponto focal e a câmara de ionização e entre o ponto focal e o piso, ambos são especificados na Tabela 6.

Tabela 6 - Especificações do Medidor de nível digital $(0$ a 360 $)$ e da Régua de precisão ${ }^{[47]}$

\begin{tabular}{|c|c|c|c|}
\hline \multicolumn{4}{|c|}{ ESPECIFICAÇÕES } \\
\hline $\begin{array}{c}\text { Medidor de nível digital (0 a } 360^{\circ} \text { ) fabricante } \\
\text { SmartTool }\end{array}$ & \multicolumn{3}{|c|}{ Exatidão em graus } \\
\hline \multirow{6}{*}{ 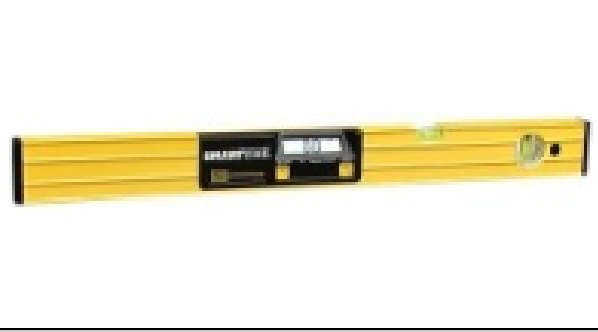 } & Ângulo & Precisão padrão & Alta precisão \\
\hline & $0^{\circ}$ e $90^{\circ}$ & $0,1^{\circ}$ & $0,05^{\circ}$ \\
\hline & $\begin{array}{l}\text { Todos os outros } \\
\text { ângulos }\end{array}$ & $0,2^{\circ}$ & $0,2^{\circ}$ \\
\hline & \multicolumn{3}{|c|}{ Resolução } \\
\hline & $-0,05^{0} a+0,05$ & $0,1^{\circ}$ & $0,05^{\circ}$ \\
\hline & $1^{\circ} \mathrm{a} 90^{\circ}$ & $0,1^{0}$ & $0,1^{0}$ \\
\hline \multirow[t]{3}{*}{ Régua de precisão } & \multicolumn{3}{|l|}{ Escala: Linear } \\
\hline & \multicolumn{3}{|c|}{ Faixa Nominal: 1000 mm } \\
\hline & \multicolumn{3}{|c|}{ Valor de uma divisão: $0,5 \mathrm{~mm}$} \\
\hline
\end{tabular}

\subsubsection{Materiais e equipamentos de referência}

\subsubsection{Filtros de alumínio}

Para a validação do dispositivo de ensaio, que utiliza filtros de baixa pureza $(99,5 \%)$, foram utilizados filtros de alumínio de alta pureza (99,9\%), Tabela 7, para comparação dos levantamentos de filtração com equivalência em qualidade dos materiais e para a determinação da CSR. 
Tabela 7 - Especificações dos Filtros de alumínio de alta pureza (99,9\% - tipo 1145) ${ }^{[48]}$

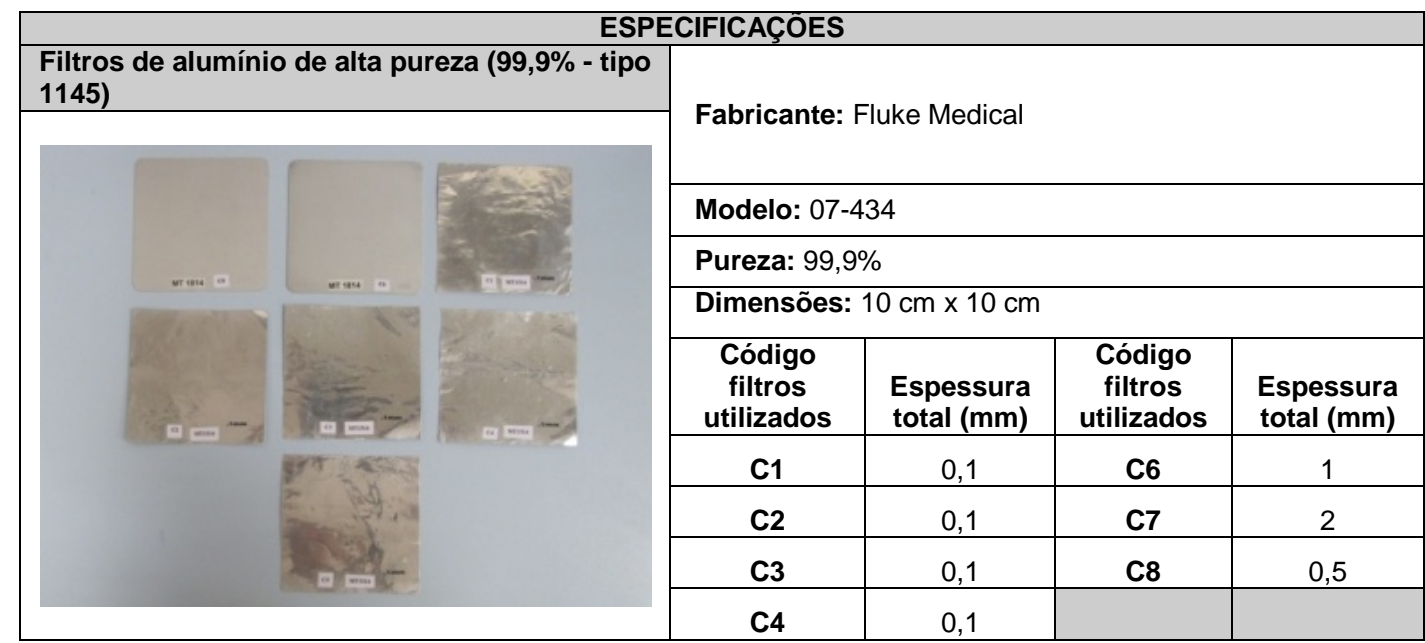

\subsubsection{Gerador de raios $X$ de referência}

O gerador de raios $X$ de referência é formado pelo gerador de altatensão, que é composto por um sistema inversor de $40 \mathrm{kHz}$ com alta estabilidade na saída, ajuste preciso de energia e com mudança de valores extremamente rápida, sendo que, qualquer flutuação ou desvio dos valores ajustados são controlados e corrigidos dentro de microssegundos, e pelo conjunto emissor de radiação $X$ com tubo de raios $X$ com janela de berílio, ambos especificados na Tabela 8 e Tabela 9.

Este gerador foi utilizado na comparação entre os ensaios realizados por ele com relação aos ensaios realizados com o dispositivo desenvolvido. As suas características estão definidas na norma IEC 60522:1999, atendendo aos requisitos da ABNT NBR IEC 60601-1-3: 2001, sub-cláusula 29.201.7, ensaio para filtração por materiais irremovíveis. Este ensaio consiste na determinação da filtração realizada por materiais irremovíveis num conjunto emissor de radiação $X$, acrescentando os valores da filtração com equivalência de qualidade de cada uma das camadas não removíveis do material que intercepta o feixe de radiação $X$. Se a informação da filtração não puder ser obtida, a filtração com equivalência de qualidade deverá ser determinada de acordo com os Itens 4 e 5 da Norma IEC 60522:1999. 
As cláusulas 29.201.8, 29.201.9 e 29.206 da ABNT NBR IEC 606011-3: 2001 são atendidas pelo gerador de raios $X$ do dispositivo desenvolvido não necessitando de condições construtivas especiais, desta forma as condições de ensaio estabelecidas pela IEC 60522:1999 podem ser estendidas para os ensaios da ABNT NBR IEC 60601-1-3: 2001.

Tabela 8 - Especificações do Gerador de alta-tensão ${ }^{[49]}$

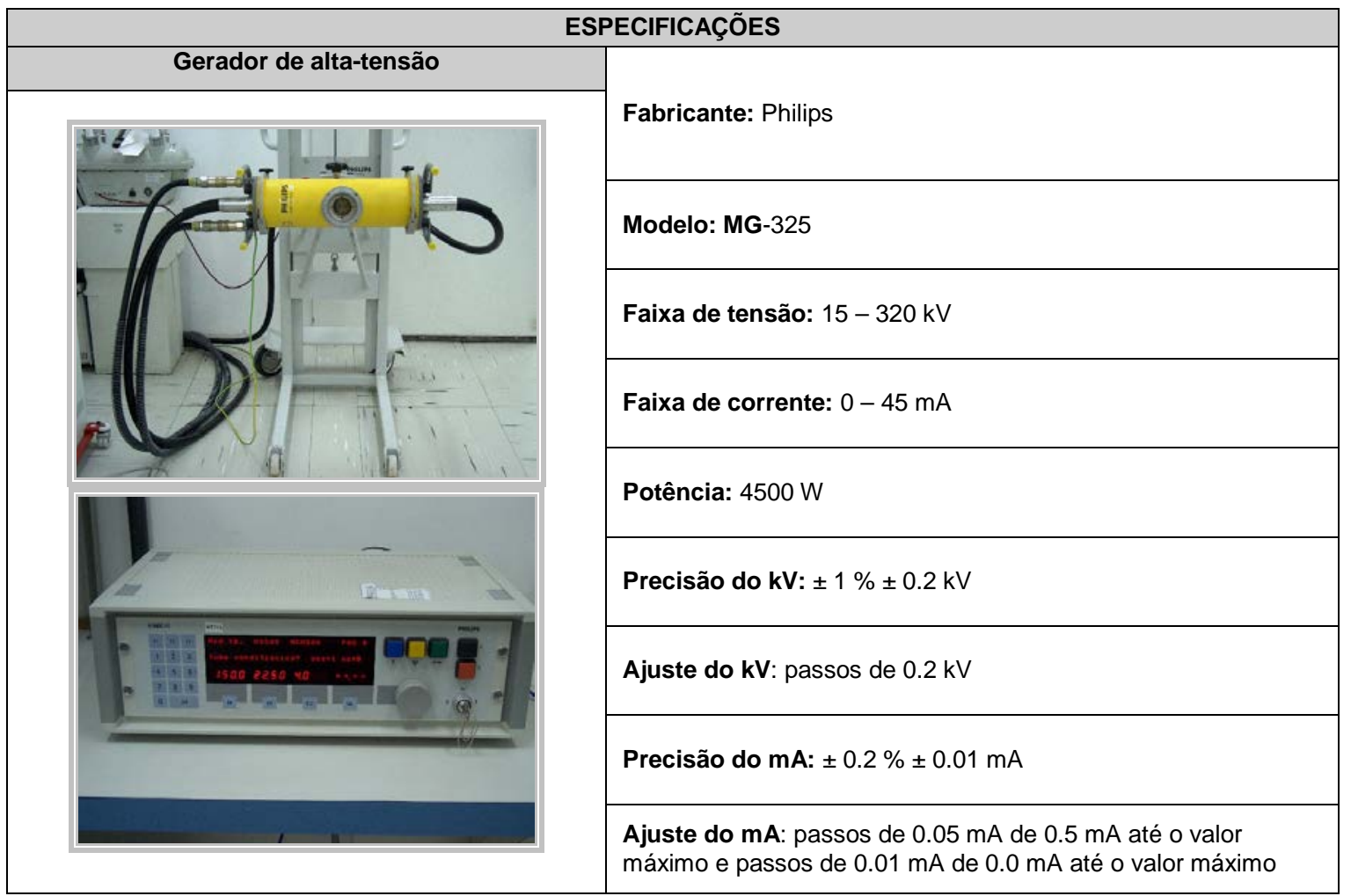

Tabela 9 - Especificações do Conjunto emissor de radiação $X$ do gerador de raios $X$ de referência ${ }^{[50]}$

\begin{tabular}{|c|c|}
\hline \multicolumn{2}{|c|}{ ESPECIFICAÇÕES } \\
\hline Conjunto emissor de radiação $X$ & \multirow[b]{2}{*}{ Fabricante: Philips } \\
\hline \multirow{9}{*}{ 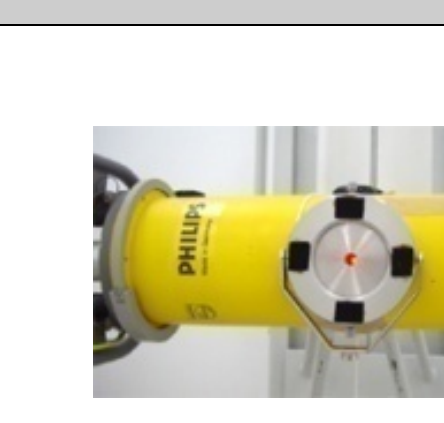 } & \\
\hline & Modelo: Y.TU 320-D01 \\
\hline & Tensão máxima do tubo de raios: $\mathrm{X}: 320 \mathrm{kV}$ \\
\hline & $\begin{array}{l}\text { Tamanho do Ponto Focal (foco fino } / \text { foco grosso): } \\
\text { (EN12543) } 0.4 \mathrm{~mm} / 1.0 \mathrm{~mm}\end{array}$ \\
\hline & Potência máxima (foco fino / foco grosso): $0.8 \mathrm{~kW} / 1.8 \mathrm{~kW}$ \\
\hline & $\begin{array}{l}\text { Corrente máxima (foco fino / foco grosso): } 2,5 \mathrm{~mA} / 5,6 \\
\mathrm{~mA}\end{array}$ \\
\hline & Ângulo do Ânodo: $22^{\circ}$ \\
\hline & Material do Ânodo: Tungstênio-rênio molibdênio \\
\hline & Filtração Inerente: $4.0 \mathrm{mmBe}, 0,2 \mathrm{mmAl}$ \\
\hline
\end{tabular}




\subsubsection{Materiais e componentes do dispositivo de ensaio}

O projeto inclui a estrutura mecânica de suportes de filtros e materiais a serem ensaiados, bem como do conjunto fonte de radiação $X$. Foi levado em consideração neste projeto a possibilidade de automação do mesmo utilizando a plataforma de desenvolvimento LabVIEW, para controle e aquisição de dados.

O dispositivo de ensaio construído é formado essencialmente de um gerador de raios $X$ de diagnóstico médico associado a componentes com finalidade de suporte e automação dos ensaios que serão realizados. $\mathrm{Na}$ sequência são descritos os elementos que compõem o dispositivo.

\subsubsection{Gerador de raios $X$ para diagnóstico médico}

O conjunto gerador de raios $X$ utilizado, formado pelo gerador de alta-tensão e conjunto fonte de radiação $X$ (formado pelo conjunto emissor $e$ pelo dispositivo alta-tensão de feixe), Tabela 10 e Tabela 11, foi doado pela empresa Philips Medical do Brasil para o propósito deste trabalho. O gerador apresenta todas as características necessárias para a realização dos ensaios descritos nesta dissertação para serem executados pelo dispositivo desenvolvido.

O estudo realizado por ALVARENGA (2005) ${ }^{[51]}$, demonstra que o gerador de raios $X$ utilizado no dispositivo desenvolvido (PHILIPS-VMI PULSAR PLUS) possui linearidade e reprodutibilidade necessários para a determinação das CSR, os seguintes resultados, diretamente relacionados ao gerador de raios $\mathrm{X}$, foram observados:

- Na determinação da repetitividade da tensão de pico, o maior valor encontrado foi de 0,009, que ficou muito abaixo do exigido, que deve ser menor que 0,1, ALVARENGA (2005); 
- Na determinação da exatidão, o maior valor encontrado foi de 1,86\%, quando o exigido deve estar dentro da faixa de $\pm 10 \%$, ALVARENGA (2005);

- Ambos testes (repetitividade e exatidão) obtiveram valor de incerteza de $3,3 \%$ para um fator de abrangência $k=2^{[37]}$, esse valor refere-se aos casos mais críticos dentre as medidas realizadas. Verificou-se neste teste que a exatidão do medidor de tensão e a dependência à filtração são as principais fontes de incerteza envolvidas no processo de medição.

Dentre as várias fontes de incerteza encontradas nos processos de medição da CSR, objeto do estudo de ALVARENGA (2005) ${ }^{[51]}$, relacionadas a geração da radiação $X$, a maioria não contribui de forma efetiva para a incerteza expandida, porém, fontes de incerteza significativas, como dependência energética do monitor de radiação, devem ser estudadas para uma melhor definição.

Tabela 10 - Especificações do Gerador de alta-tensão ${ }^{[52]}$

\begin{tabular}{|c|c|}
\hline \multicolumn{2}{|c|}{ ESPECIFICAÇÕES } \\
\hline Gerador de alta-tensão & \multirow[b]{2}{*}{ Fabricante: Philips - VMI } \\
\hline & \\
\hline$\therefore \ldots$ & Modelo: PULSAR Plus \\
\hline & Faixa de tensão: $30-150 \mathrm{kV}$, com incrementos de $1 \mathrm{kV}$ \\
\hline & Faixa de corrente: $0-800 \mathrm{~mA}$ \\
\hline & Potência (mA @ kVp): $640 @ 100,800 @ 64$ \\
\hline & Precisão do kV: $\pm 2 \% \mathrm{kV}$ \\
\hline & Ajuste do kV: passos de $1 \mathrm{kV}$ \\
\hline & Precisão do $\mathrm{mA}: \pm 5 \% \mathrm{~mA}$ \\
\hline & $\begin{array}{l}\text { Faixa de } m A \text { Foco fino }(\mathrm{mA}): 25-150 \\
\text { Faixa de mA Foco Grosso (mA): } 200-500 / 600 / 800\end{array}$ \\
\hline
\end{tabular}


Tabela 11 - Especificações do Conjunto emissor de radiação X

\begin{tabular}{|c|c|}
\hline \multirow[t]{2}{*}{ Conjunto-emissor de radiação $\mathrm{X}^{[53,54]}$} & \multirow[b]{2}{*}{ Fabricante: Varian Medical Systems } \\
\hline & \\
\hline & $\begin{array}{l}\text { Modelo: Diamond com tubo de raios } X \text { de ânodo giratório } \\
\text { RAD-68 }\end{array}$ \\
\hline & Tensão máxima do tubo de raios: $\mathrm{X}: 150 \mathrm{kV}$ \\
\hline 1 & $\begin{array}{l}\text { Tamanho do Ponto Focal (foco fino / foco grosso): } 1,0 \text { - } \\
2,0\end{array}$ \\
\hline & $\begin{array}{l}\text { Potência máxima (foco fino / foco grosso): } 54 \text { kW / } 96 \\
\text { kW }\end{array}$ \\
\hline . & $\begin{array}{l}\text { Corrente máxima (foco fino / foco grosso): } 2,5 \mathrm{~mA} / 5,6 \\
\mathrm{~mA}\end{array}$ \\
\hline & Ângulo do Ânodo: $14^{\circ}$ \\
\hline & Material do Ânodo: Tungstênio-rênio molibdênio \\
\hline 6 & Filtração Inerente: $0,7 \mathrm{mmAl}$ \\
\hline
\end{tabular}

\subsubsection{Dispositivo limitador de feixe}

A função do dispositivo limitador de feixe, especificado em suas configurações originais na Tabela 12, é propiciar a condição de feixe estreito. A condição de feixe estreito é exigida nos ensaios de acordo com o detalhamento do item 3.5.1. Este dispositivo foi adaptado através da remoção dos elementos que proporcionavam filtração adicional, neste caso o acrílico e espelho, resultando em uma filtração total desprezível necessária para atender os requisitos dos ensaios.

Tabela 12- Especificações do dispositivo limitador de feixe ${ }^{[55]}$

\begin{tabular}{|c|c|}
\hline \multicolumn{2}{|c|}{ ESPECIFICAÇŌES } \\
\hline Dispositivo Limitador de feixe & $\begin{array}{l}\text { Fabricante: Leadmec } \\
\text { Modelo: LDM-206 }\end{array}$ \\
\hline & Limitação de radiação extra focal: $\mathbf{2 9 . 2 0 2 . 3 ~ 1 5 0 m m ~}$ \\
\hline & Radiação de Fuga 29.209.3: Conforme NBR IEC 60601-1-3 \\
\hline & $\begin{array}{l}\text { Seleção do Campo de Raio-X } 100 \mathrm{~cm} \text { 29.202.4: Min } 0 \times 0 \mathrm{~cm} \\
\text { Max } 43 \times 43 \mathrm{~cm} \pm 2 \%\end{array}$ \\
\hline & $\begin{array}{l}\text { Filtros adicionais que interceptam o feixe de radiação } X \\
\text { 29.201.8: Acrílico: (mmAl) } 0,10 \text { Espelho: (mmAl)1,69 Total: } \\
\text { (mmAl)1,80 }\end{array}$ \\
\hline & Iluminação Indicadora do Campo $100 \mathrm{~cm}$ 29.202.7: 160 LUX \\
\hline & Contraste luminoso do campo $100 \mathrm{~cm} 29.202 .7: 3: 1$ \\
\hline & $\begin{array}{l}\text { Precisão da escala indicadora do Campo de Raio-X } \\
\text { 29.202.8: } 2 \%\end{array}$ \\
\hline$=$ & $\begin{array}{l}\text { Precisão de Correspondência entre Campo lluminado I } \\
\text { Campo de Raio-X 29.203.9: } 2 \%\end{array}$ \\
\hline
\end{tabular}




\subsubsection{Filtros de alumínio de baixa pureza (99,5\% - tipo 1100)}

Os filtros de alumínio de baixa pureza, especificados na Tabela 13, foram instalados de forma permanente no dispositivo trocador de filtros, os mesmos foram validados quanto aos fatores de influência na determinação da CSR.

Os fatores considerados foram a distância entre os filtros, a ordem dos filtros com relação à espessura e a pureza destes. Os filtros de alta pureza foram utilizados para a validação através de comparação com filtros de baixa pureza.

Tabela 13 - Especificações dos filtros de baixa pureza ${ }^{[56]}$

\begin{tabular}{|c|c|c|c|c|}
\hline \multicolumn{5}{|c|}{ ESPECIFICAÇÕES } \\
\hline $\begin{array}{l}\text { Filtros de alumínio de baixa } \\
\text { pureza }(99,5 \% \text { - tipo } 1100)\end{array}$ & \multicolumn{4}{|c|}{ Fabricante: Radcal Co. } \\
\hline \multirow{4}{*}{ 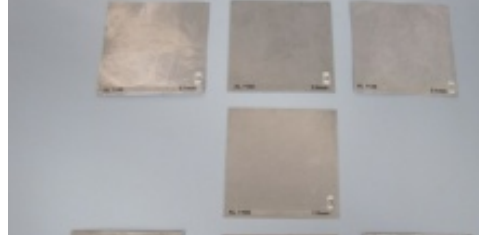 } & \multicolumn{4}{|c|}{ Modelo: Parte integrante conjunto de medição modelo 9095} \\
\hline & \multicolumn{4}{|l|}{ Pureza: $99,5 \%$} \\
\hline & \multicolumn{4}{|c|}{ Dimensões: $10 \mathrm{~cm} \times 10 \mathrm{~cm}$} \\
\hline & $\begin{array}{c}\begin{array}{c}\text { Código filtros } \\
\text { utilizados }\end{array} \\
\end{array}$ & $\begin{array}{l}\text { Espessura } \\
\text { total }(\mathrm{mm})\end{array}$ & $\begin{array}{c}\text { Código filtros } \\
\text { utilizados }\end{array}$ & $\begin{array}{l}\text { Espessura } \\
\text { total }(\mathrm{mm})\end{array}$ \\
\hline & C1 & 0,1 & C6 & 1 \\
\hline & C3 & 0,1 & C7 & 2 \\
\hline & $\mathrm{C4}$ & 0,1 & C10 & 0,5 \\
\hline & C5 & 0,1 & & \\
\hline
\end{tabular}

\subsubsection{Dispositivo trocador de filtros}

O dispositivo trocador de filtros é a parte principal deste trabalho, pois o mesmo torna possível a troca de filtros de maneira remota possibilitando a seleção dos filtros de alumínio de baixa pureza $(99,5 \%)$ para a determinação da CSR e da filtração com equivalência em alumínio estabelecida pelos ensaios.

O dispositivo trocador de filtros foi montado utilizando a estrutura mecânica de drives de CD’s de computador, cujos leitores ópticos estavam inoperantes. O reaproveitamento dos drives foi possível, em função da utilização apenas do sistema mecânico de entrada e saída do compartimento, onde, no lugar do CD foram instalados os filtros de alumínio de baixa pureza. 
Foram utilizados sete drives montados e posicionados de tal maneira que foi possível obter todas as combinações possíveis e necessárias para a determinação da CSR e da filtração com equivalência de qualidade dos materiais que compõem a filtração inerente e dos materiais que interceptam o feixe de radiação $X$ após o saída do mesmo do conjunto emissor de radiação $\mathrm{X}$.

O sistema de drives é controlado através do software desenvolvido na plataforma Labview, acionando o drive em função do filtro de alumínio a ser utilizado de maneira remota, além disso, a proposta é que o software controle o gerador de Raios X e o sistema de medição de dose de forma que através da combinação do filtro e da dose medida seja possível obter a curva da CSR.

A Figura 37 ilustra o dispositivo trocador de filtros, divididos como segue:

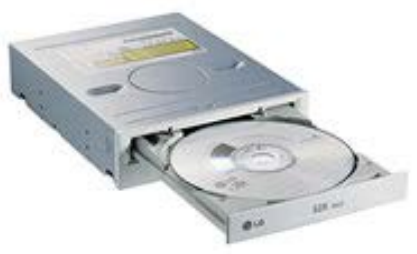

(a) Drive de Cd utilizado

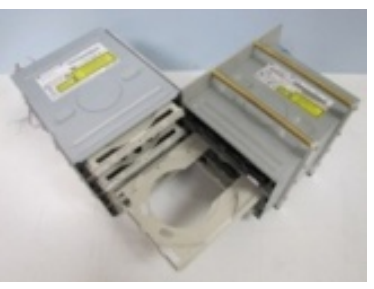

(d) um dos drives deslocado para fora do gabinete

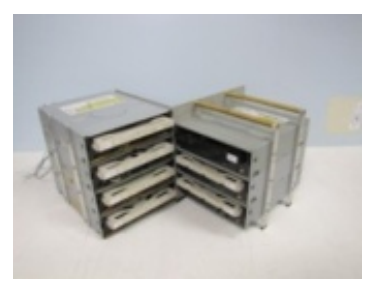

(b) sistema com todos os drives fechados.

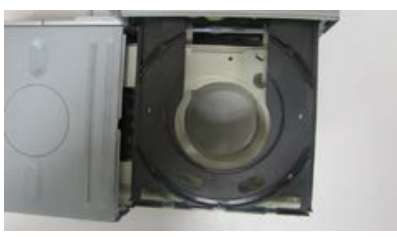

(e) todos os drives deslocados para fora do gabinete plano superior, mostrando o
alinhamento dos drives

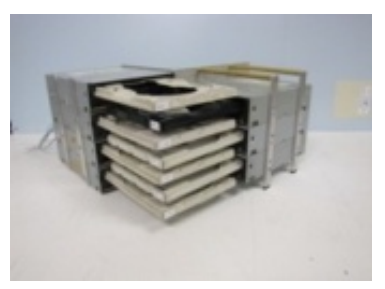

(c) todos os drives deslocados para fora do qabinete.

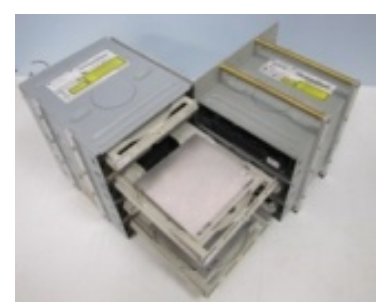

(g) disposição do filtro na "gaveta" do drive

Figura 37 - Fotos do dispositivo trocador de filtros 


\subsubsection{Driver de controle}

O dispositivo trocador de filtros é conectado a dois módulos de saída analógica NI 9263, Figura 38, e acoplado no gabinete NI cDAQ-9172 Figura 39, ambos fabricados pela National Instruments, e é controlado por um circuito chaveador, Figura 41 e Figura 42.

O módulo NI 9263 de saída analógica para sistemas embarcados NI CompactRIO, possui as seguintes características:

- $\pm 10 \mathrm{~V}$ e 0 a $20 \mathrm{~mA}$ intervalos de saída analógicos, 16 bits de resolução, 100 kS / s de taxa de atualização simultânea;

- 4 canais por módulo com Isolação de até 2.300 Vrms (suportado) e até 250 Vrms (operação contínua) por canal digital-analógico (DAC) para a saída analógica simultânea;

- $\pm 30 \mathrm{~V}$ de proteção contra sobre-tensão e curto-circuito para conexão direta com atuadores e dispositivos industriais

O circuito chaveador é necessário, pois a placa de aquisição não possui o nível de tensão necessário para acionar diretamente os motores dos drives de CD do dispositivo trocador de filtros.

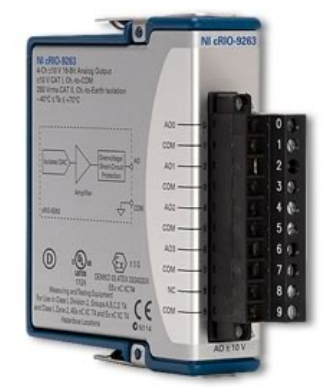

Figura 38 - Modulo de saída analógica NI 9263.

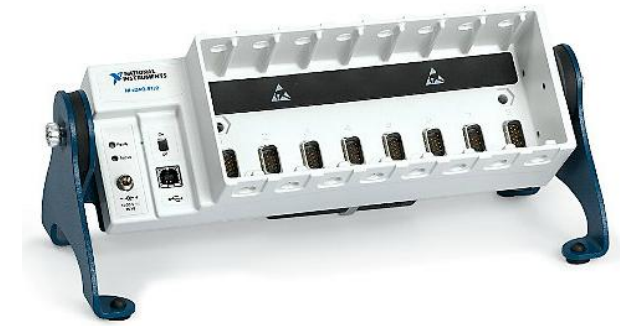

Figura 39 - Gabinete NI cDAQ-9172 
O circuito chaveador é composto de 7 módulos de chaveamento idênticos, Figura 40, para acionar de maneira independente cada drive de CD. O funcionamento do circuito chaveador se dá através de pulsos analógicos, sinais positivos e negativos, por exemplo, quando um pulso positivo é aplicado na entrada D1 (polarização direta da base do transistor NPN D1) o motor CC do drive de $\mathrm{CD}$ fará deslocar a "gaveta" para fora do drive (sinal positivo +VCC no coletor de Q1), o pulso aplicado possui um período especifico da ordem de 5 segundos, que é o tempo necessário para o deslocamento, pois se o tempo for demasiadamente longo poderá provocar danos ao motor. Para que a "gaveta" retorne para o interior do drive é necessário um pulso negativo em D1 que polarizara diretamente a base do transistor PNP Q2 fazendo com que o mesmo conduza (sinal negativo - $\mathrm{VCC}$ no emissor de Q2) acionando o motor no sentido contrário.

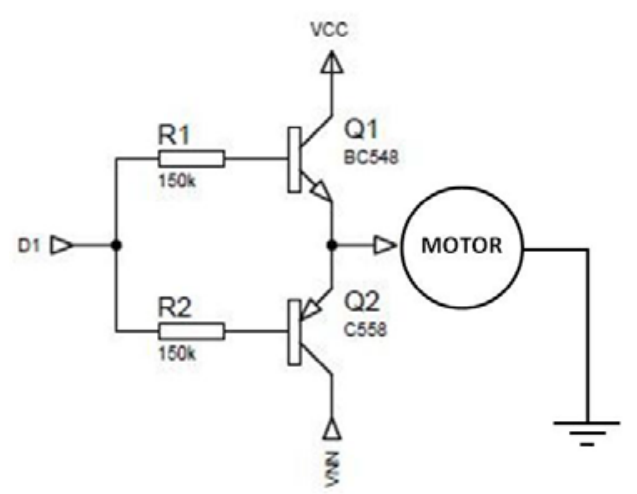

Figura 40 - Módulo do circuito chaveador

O circuito chaveador é alimentado por uma fonte de alimentação,

Figura 43 simétrica, que é essencial para a inversão de polaridade da alimentação dos motores, como dito anteriormente, tal inversão provoca o movimento de entrada e saída da "gaveta" do drive de CD.

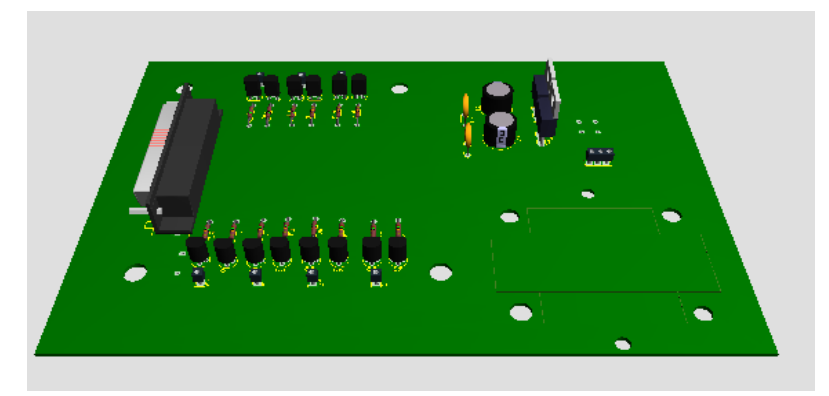

Figura 41 - Circuito chaveador, topologia de montagem 


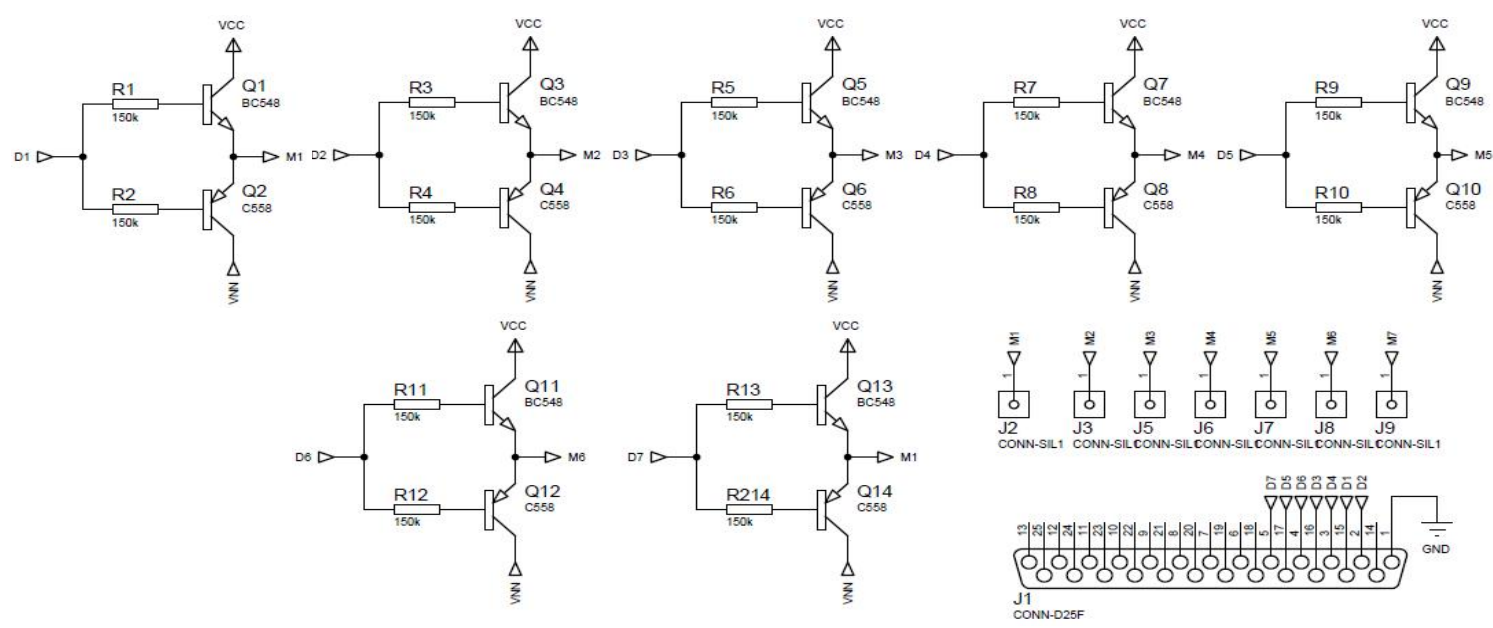

Figura 42 - Esquema eletrônico do circuito chaveado

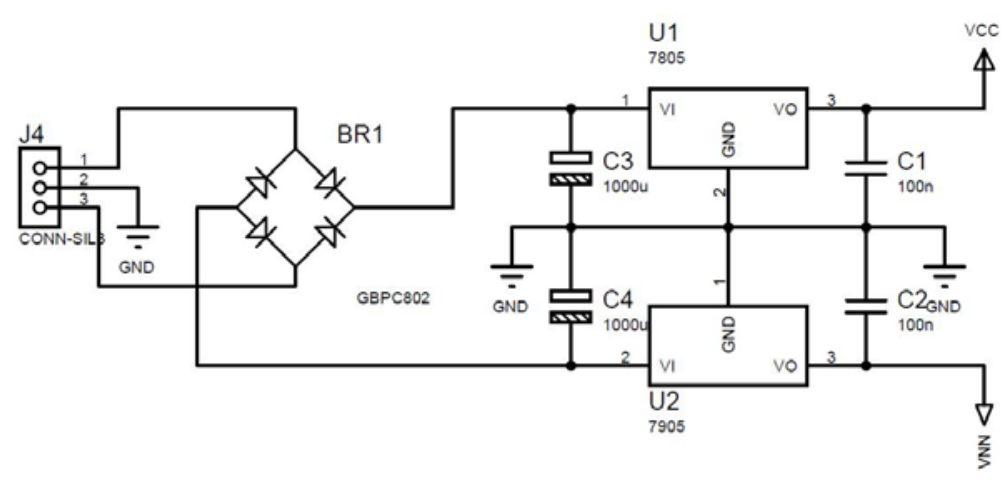

Figura 43 - Esquema eletrônico da fonte simétrica

Após a conclusão e montagem do circuito chaveador e da fonte de alimentação na placa de circuito impresso e a instalação desta no dispositivo trocador de filtros o mesmo foi concluído. A Figura 44 ilustra a placa montada com os componentes eletrônicos, a figura mostra a ligação do dispositivo trocador de filtros com o Modulo digital NI 9263 e com o Gabinete NI cDAQ9172.

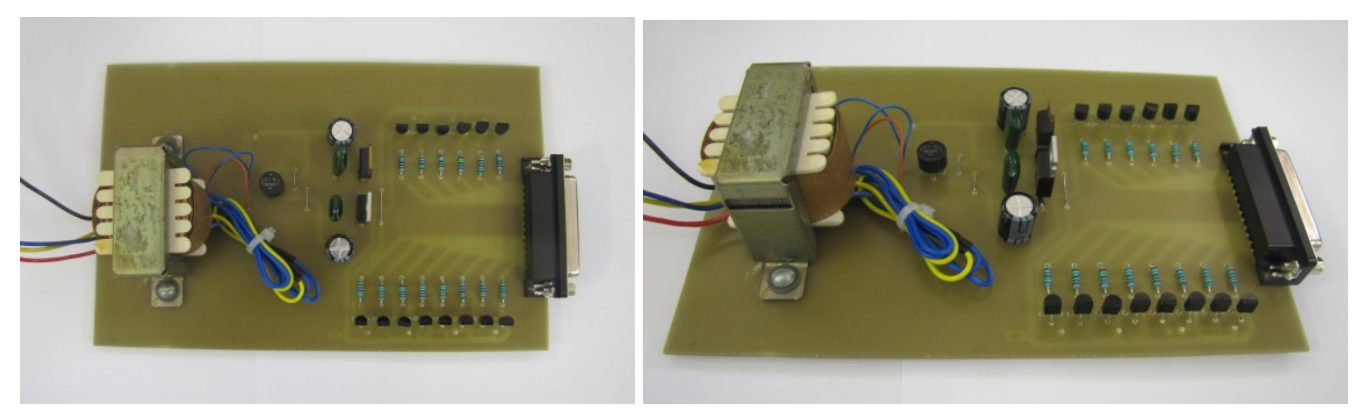

Figura 44 - montagem do circuito chaveador e fonte de alimentação 
As figuras que seguem mostram as etapas finais do dispositivo de ensaio desenvolvido. A Figura 45 mostra a instalação da placa de circuito impresso do chaveador na montagem do suporte dos drives de CD, nesta instalação foi realizada a ligação dos motores dos drives de CD.
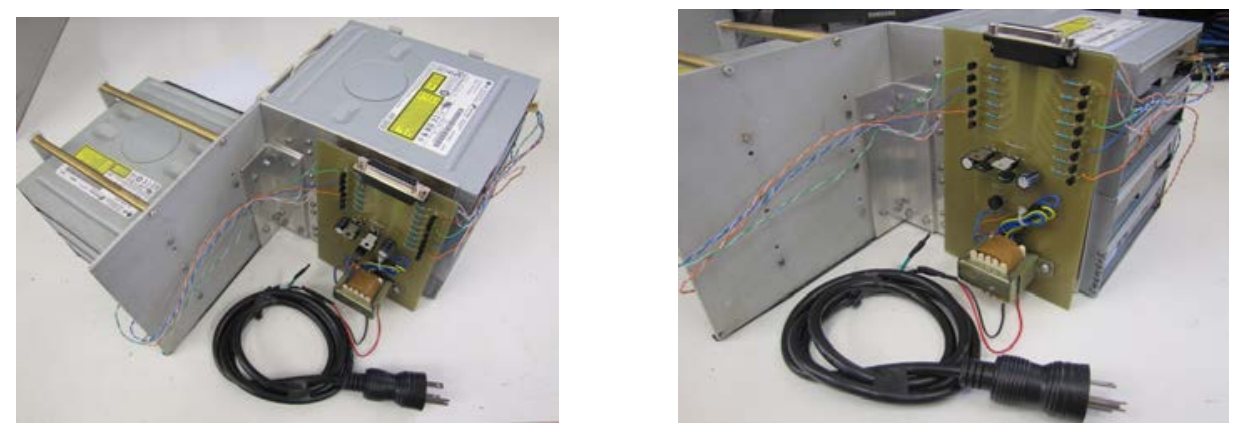

Figura 45 - Instalação do circuito chaveador na montagem do suporte dos drives de CD

A Figura 46 mostra a Conexão do dispositivo trocador de filtros com o Modulo digital NI 9263 acoplado no Gabinete NI cDAQ-9172 que é conectado por meio de um cabo USB ao computador onde o software de controle é instalado.
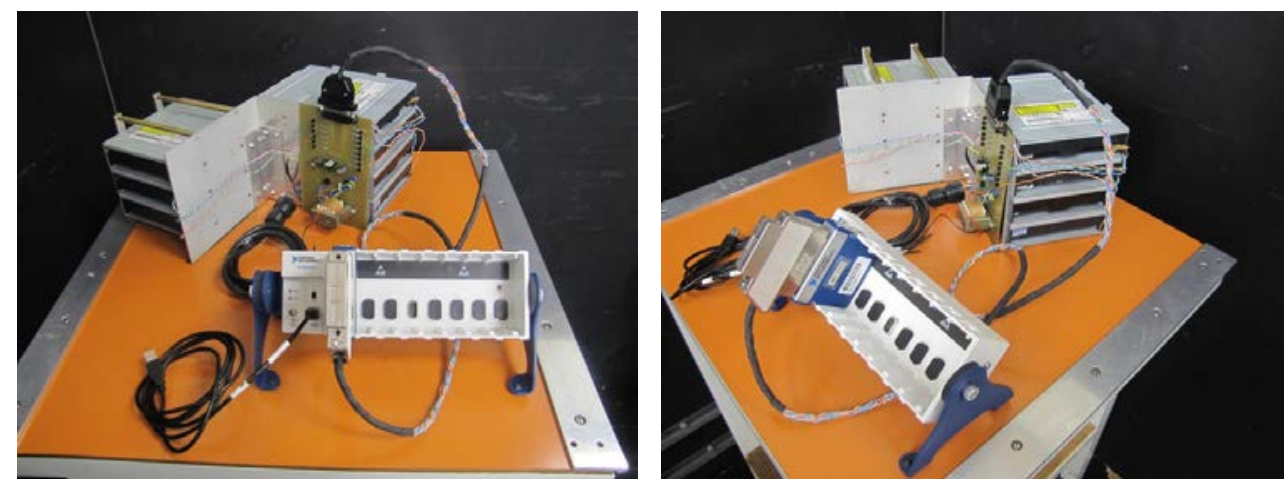

Figura 46 - Conexão do dispositivo trocador de filtros com a placa de controle

A Figura 47 e Figura 48 mostram a instalação do dispositivo trocador de filtros na estrutura mecânica, geometria fixa.
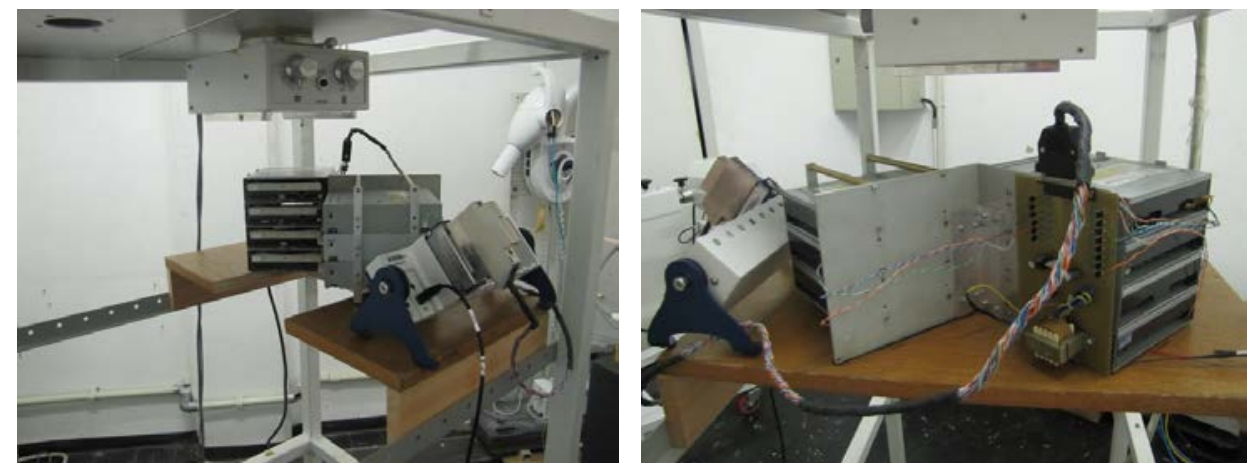

Figura 47 - Dispositivo trocador de filtros instalado na estrutura mecânica 

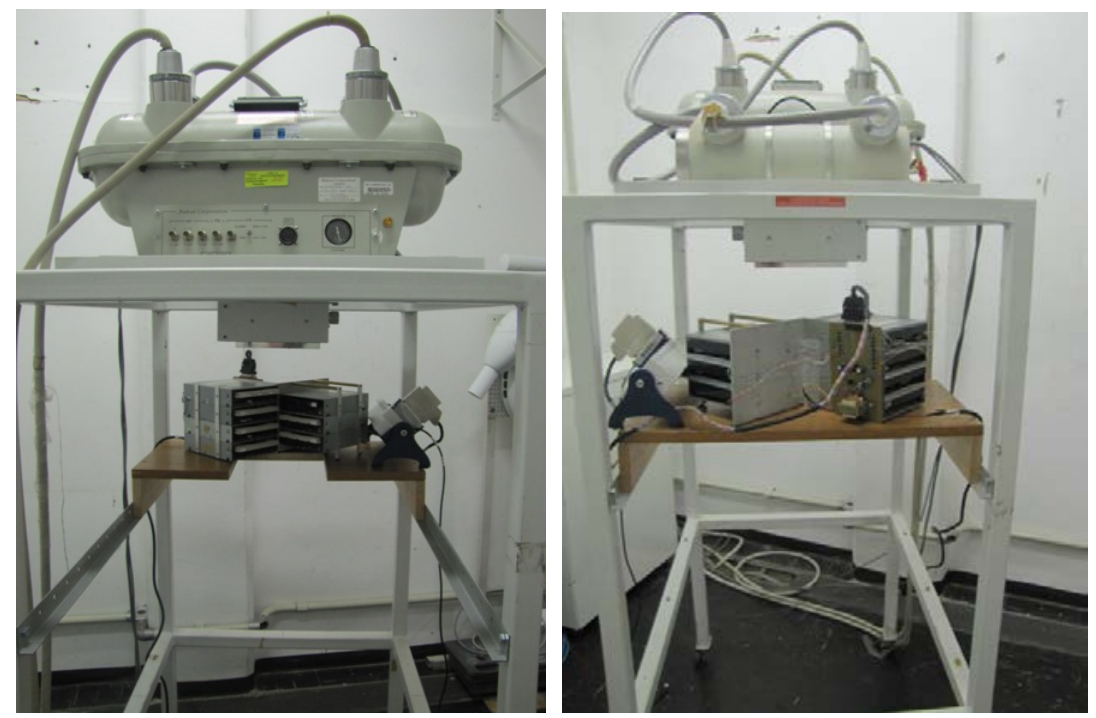

Figura 48 - Vistas frontal e traseira da montagem final do dispositivo de ensaio

O sistema de aquisição e controle, da National Instruments adotado neste trabalho, torna possível a utilização em várias aplicações, isto é, o sistema de controle não é dedicado exclusivamente ao dispositivo de ensaio desenvolvido permitindo que tal sistema seja desconectado e utilizado em outras aplicações desenvolvidas na qual o mesmo está inserido.

\subsubsection{Software de controle do dispositivo trocador de filtros}

O controle do dispositivo trocador de filtros assim como a aquisição de sinais provenientes do leitor de parâmetros radiológicos modelo 9095 da Radcal Co, ver item 4.1.2, é realizado por meio de um software de controle desenvolvido na plataforma LabVIEW. O software permite a seleção remota dos filtros durante a realização dos ensaios evitando que o operador do laboratório tenha que realizar tal operação manualmente, o software permite também a aquisição dos valores medidos de kerma no ar efetuada pelo medidor de parâmetros radiológicos. Na Figura 49 é apresentado o painel de configuração da comunicação serial entre o sistema 9095 e 0 microcomputador. Esta parte do software foi aproveitada do sistema de medição já anteriormente desenvolvido pela STEEE ${ }^{[57]}$. Adicionalmente, o programa efetua comunicação com o modulo digital NI 9263 acoplado no gabinete NI cDAQ-9172 para controle dos drivers e posicionamento dos filtros durante os ensaios. 


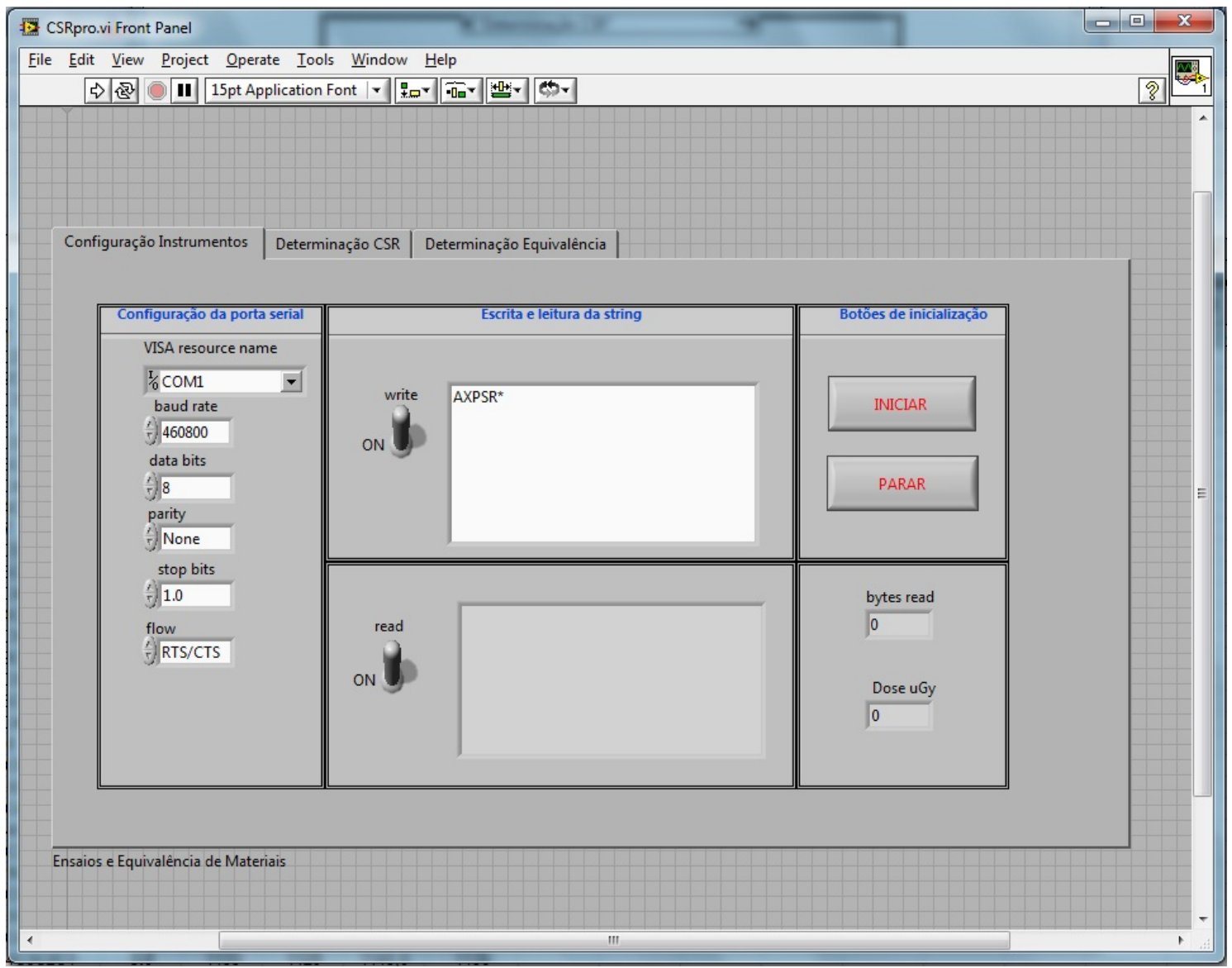

Figura 49 - Painel de configuração da comunicação com o sistema de aquisição

Na Figura 50 é mostrado o painel do ensaio para a determinação da CSR, onde:

1 Indicação do filtro em utilização ("Ativo");

2 Posição do filtro utilizado no dispositivo trocador de filtros;

3 Codificação dos filtros utilizados;

4 Espessura dos filtros utilizados;

5 Gráfico mostrando a relação entre kerma no ar e espessuras de filtro para posterior determinação da CSR;

6 Valor inicial de kerma no ar para a determinação da CSR, I $\mathrm{I}_{0}$;

7 Valor encontrado de kerma no ar na determinação da CSR, ICSR;

8 Valor em mmAl da CSR;

9 Indicador da CSR que é acionado automaticamente quando a CSR é encontrada;

10 Botão de inicialização do ensaio, acionamento do programa. 


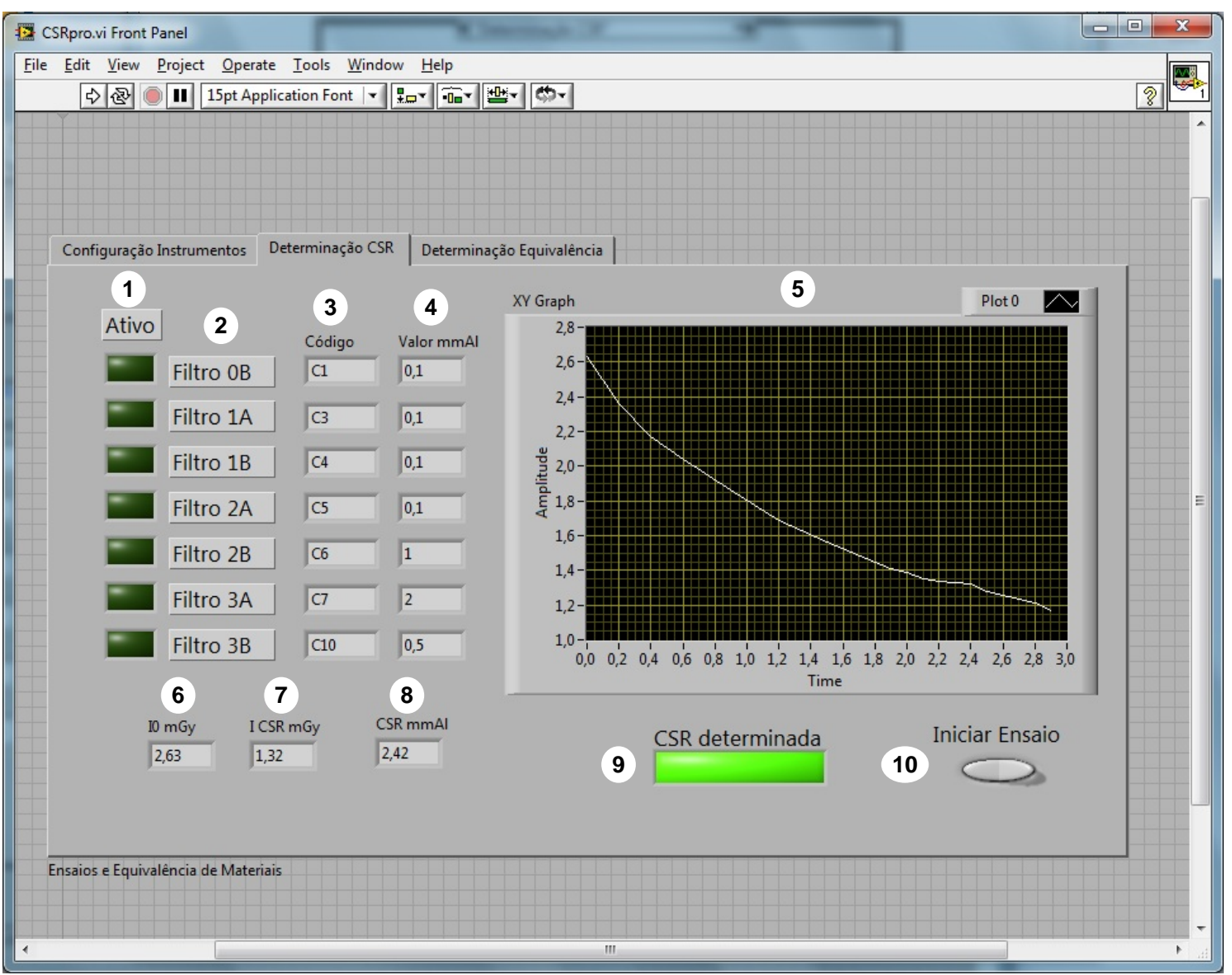

Figura 50 - Painel do ensaio para a determinação da CSR seguinte forma:

O método ensaio para a determinação da CSR é realizado da

a) O botão "iniciar ensaio" (10) é acionado para inicializar o software;

b) O valor de $I_{0}(6)$ é determinado por meio de uma medição de kerma no ar sem nenhum filtro;

c) Após a determinação do $I_{0} 0$ valor de $I_{C S R}$ (7) deve ser determinado por meio de combinações experimentais dos filtros (2) até que valor de $I_{\text {CSR }}$ seja a metade de $\mathrm{I}_{0}$ (levando em conta as incertezas de medição envolvidas);

d) A determinação do $I_{\text {CSR }}$ (7) depende de $n$ irradiações até que o valor do mesmo seja encontrado, desta forma o software, após cada irradiação, ou seja, após cada valor de kerma enviado pelo sistema de medição 9095, emite um alerta para o operador efetuar mais um disparo por meio de uma caixa de mensagem "medição finalizada. Efetue outra irradiação", essa mensagem será repetida até que o $I_{C S R}$ (7) seja determinado; 


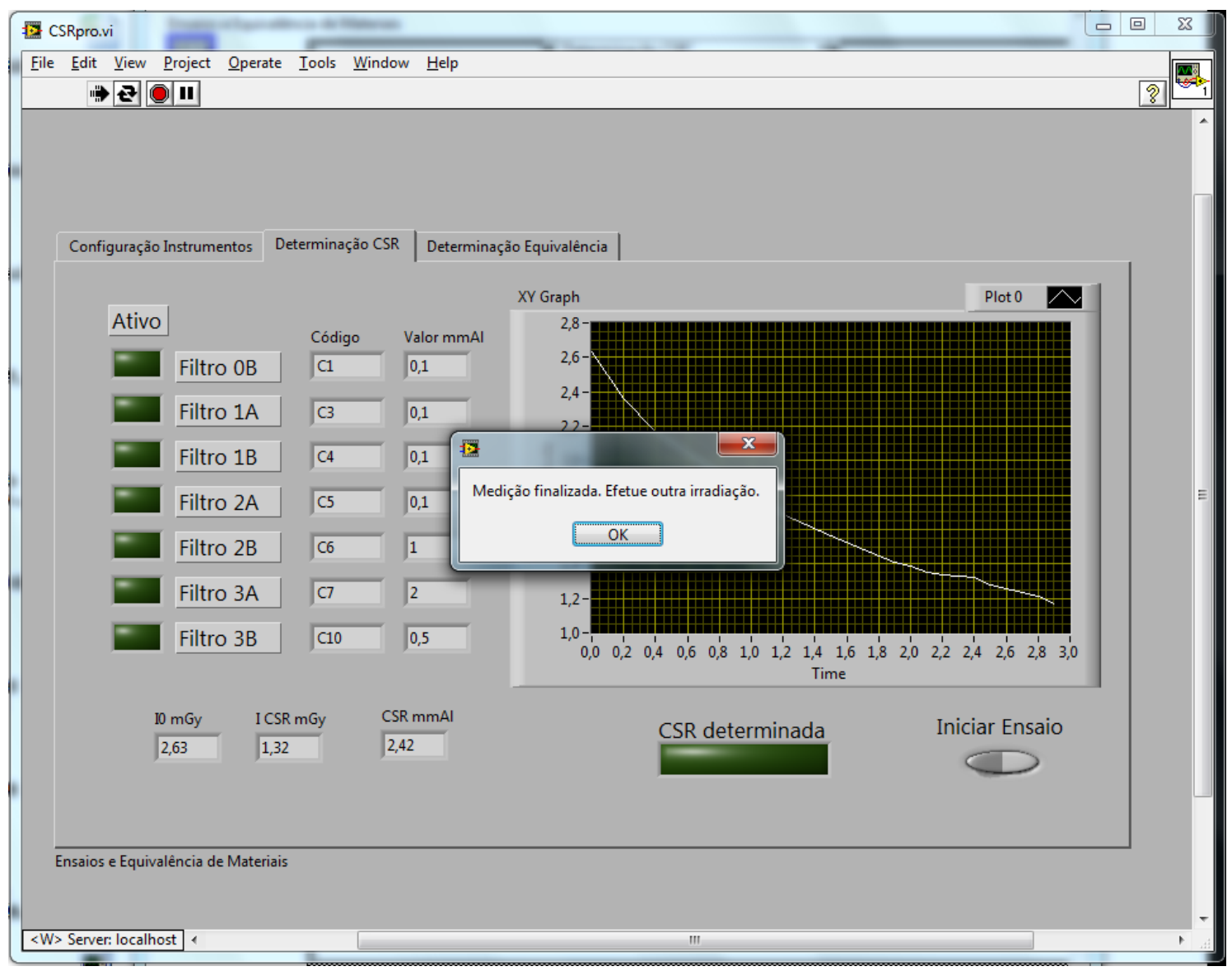

Figura 51 - Mensagem de medição finalizada

e) Quando o valor de I $\mathrm{CSR}_{\text {f }}$ for encontrado o indicador "CSR determinada" (9) será acionado sinalizando que a determinação foi finalizada. Esta finalização ocorre após o cálculo da interpolação que era realizado pelo software HVLcalc ${ }^{[17]}$, item 4.2.7, que foi incorporado ao software como uma sub-VI. O valor da CSR em mmAl será a somatória dos filtros utilizados (incorporando a incerteza de medição dos filtros)

Na Figura 52 é mostrado o painel do ensaio para a determinação da filtração com equivalência da qualidade em mmAl dos materiais que interceptam o feixe de raios $X$, materiais removíveis e irremovíveis (filtração inerente), onde:

1 Indicação do material avaliado;

2 CSR do material avaliado;

3 Equivalência em mmAl do material avaliado;

4 Importação dos dados obtidos no painel "Determinação CSR". 


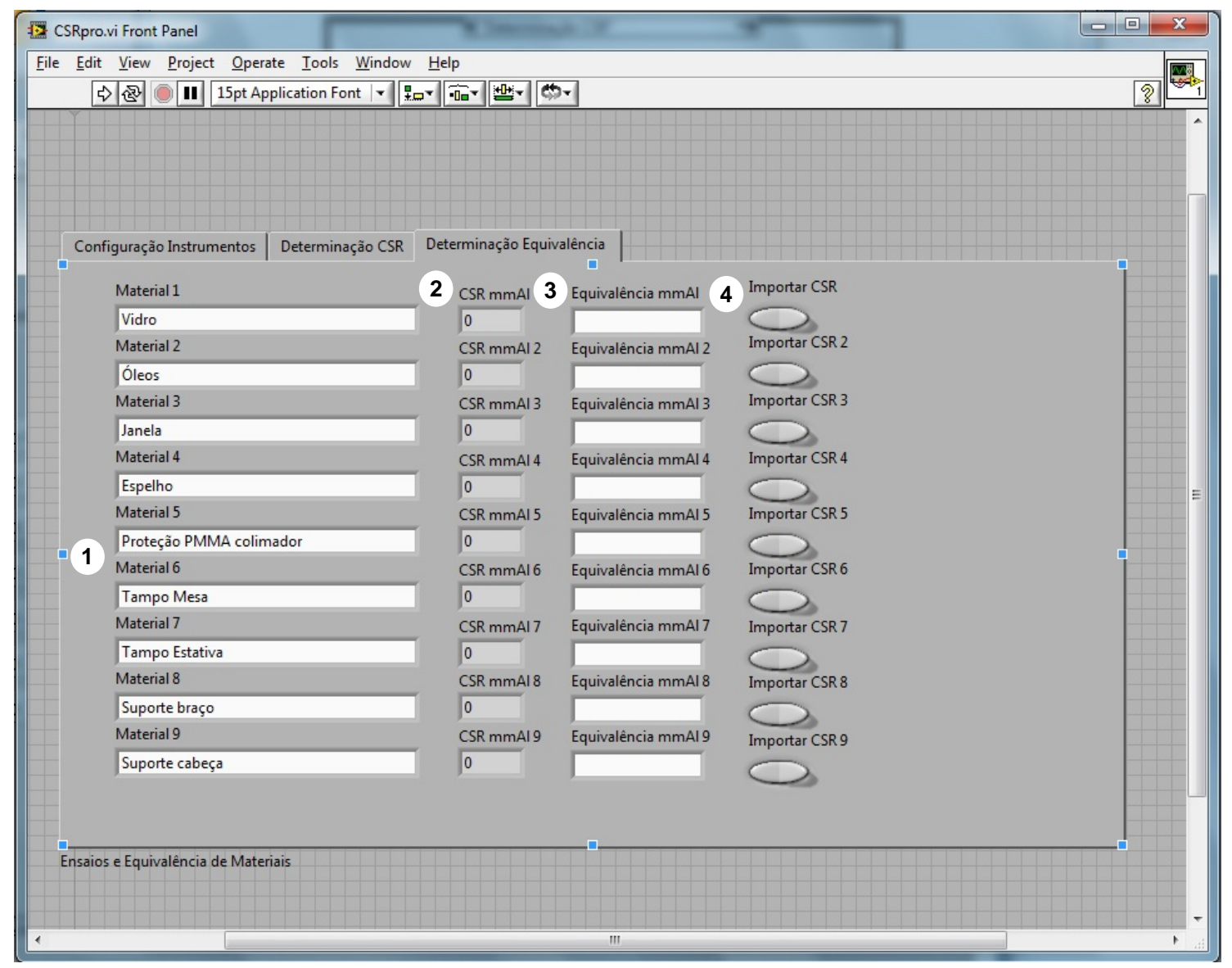

Figura 52 - Painel do ensaio para a determinação da filtração com equivalência da qualidade em mmAl

O ensaio para a determinação da filtração com equivalência da qualidade em mmAl é realizado de maneira similar a determinação da CSR, onde:

a) o material (1) é interposto entre o feixe de raios $X$ e o sistema de aquisição para a determinação do $I_{0}$ (painel de determinação da CSRFigura 50);

b) os filtros de alumínio são adicionados para a determinação da "CSR mmAl" (2), I ICSR (painel de determinação da CSR- Figura 50);

c) Após a determinação do $I_{C S R}$ o botão "Importar CSR" é acionado para importar o valor para o campo "CSR mmAl" (2);

d) o material (1) é removido e em seu lugar são adicionados os filtros de alumínio para a determinação da equivalência em mmAl, IcsR (painel de determinação da CSR- Figura 50); 
e) Após a determinação do I ISR o botão "Importar CSR" é acionado para importar o valor para o campo "equivalência em mmAl" (3).

Os passos de a) até e) devem ser repetidos para cada material avaliado.

\subsubsection{Estrutura mecânica}

A estrutura mecânica é utilizada para o suporte do conjunto emissor de radiação $X$, do divisor de alta-tensão do dispositivo trocador de filtros e da câmara de ionização utilizada no sistema de medição de kerma no ar.

O dispositivo foi construído de modo a atender, além dos critérios estabelecidos anteriormente, a geometria de medição estabelecida pela norma IEC 61267:2005 ${ }^{[58]}$, Figura 53 e Figura 54.

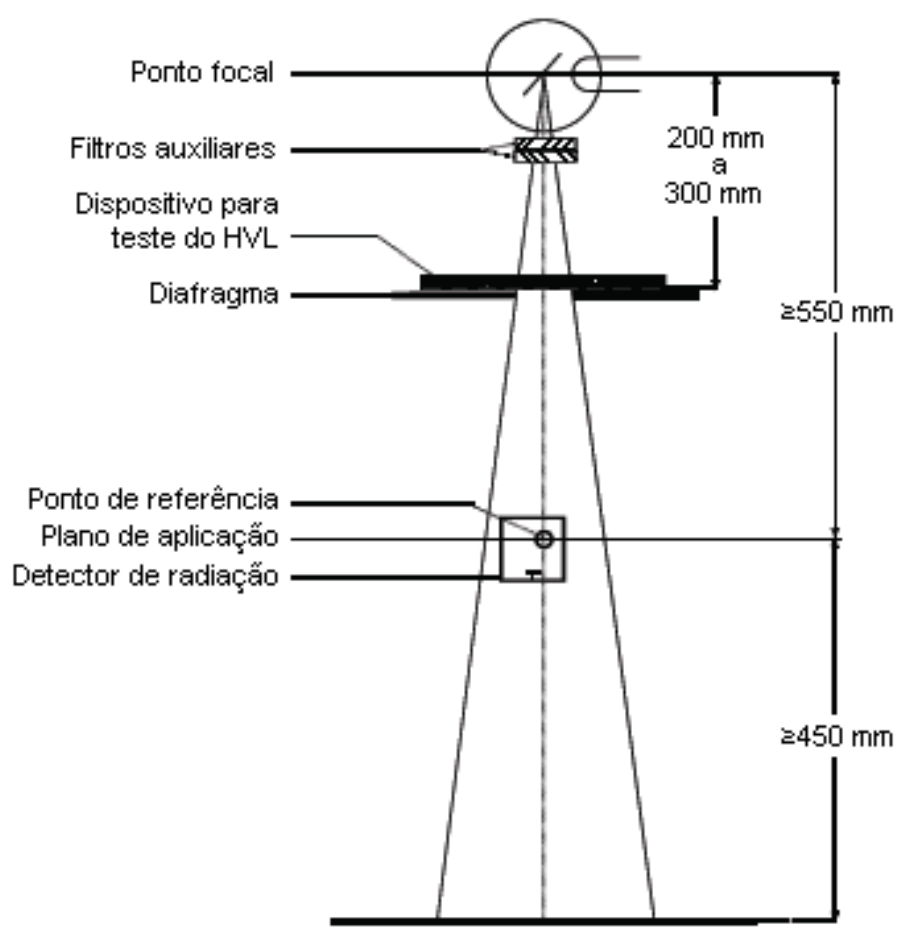

Figura 53 - Arranjo para o ensaio de determinação da CSR segundo a Norma IEC61267 


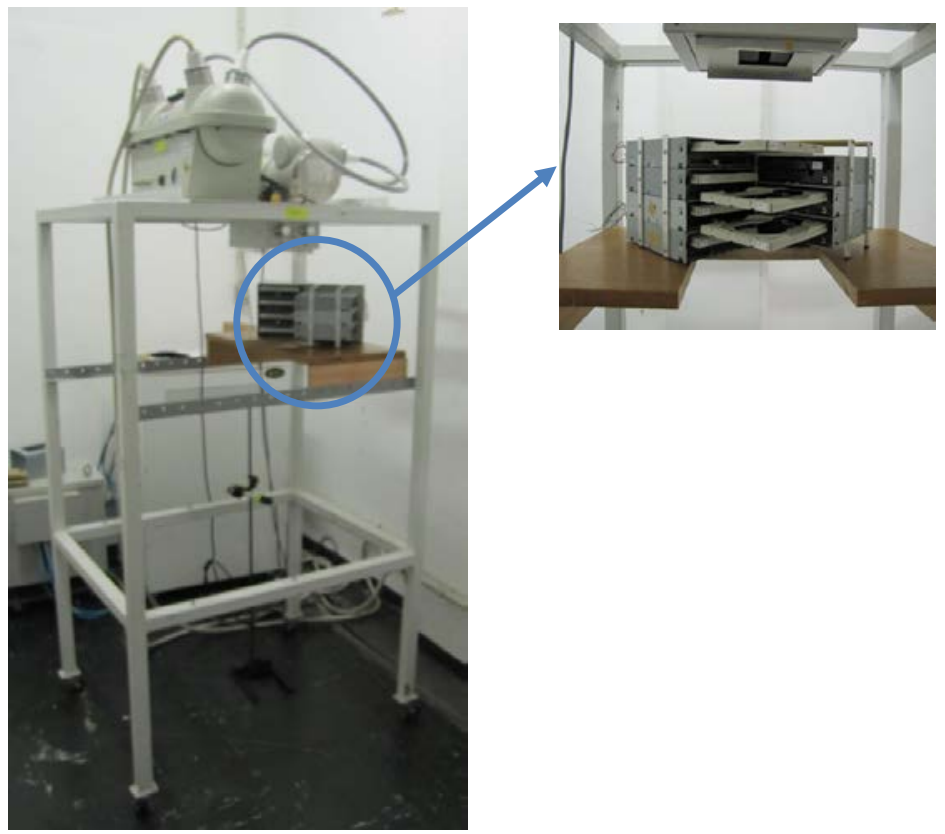

Figura 54 - Dispositivo de ensaio montado.

A norma IEC 61267: 2005 estabelece os procedimentos para a determinação de características dos componentes de ou sistemas de equipamento de raios $X$ para diagnóstico médico. A norma define também os métodos para gerar feixes de radiação com critérios que devem ser utilizados pelos laboratórios de ensaio e calibração para a determinação de características de equipamentos de raios $\mathrm{X}$ para diagnóstico médico.

O valor da CSR está diretamente ligado às características intrínsecas do tubo de raios $X$ e dos materiais que compõem o conjunto emissor de radiação X. A Norma IEC61267 define uma geometria de feixe estreito para determinação das qualidades dos feixes na faixa de radiologia diagnóstica. 


\subsection{MÉTODOS}

Este trabalho foi desenvolvido na Seção Técnica de Ensaios em Equipamentos Eletromédicos (STEEE) e o resultado dos ensaios do dispositivo de ensaio proposto foi comparado com o arranjo montado na Seção Técnica de Desenvolvimento Tecnológico em Saúde (STDTS) do Instituto de Eletrotécnica e Energia da Universidade de São Paulo -IEE-USP.

\subsubsection{Critérios para o desenvolvimento do dispositivo de ensaio}

Para a construção do dispositivo de ensaio foram estabelecidos critérios, além daqueles envolvidos com a execução dos ensaios, relacionados às questões da acreditação da STEEE junto ao INMETRO, segurança e otimização e questões ambientais. Na sequencia são descritos os critérios que foram determinantes para a condução deste trabalho.

\subsubsection{Estar de acordo com os requisitos da ABNT NBR IEC 60601-1-3: e com a norma IEC 60522: $1999^{[59]}$ (Apêndice 1, Apêndice 2, Apêndice 3 e Apêndice 4);}

Os ensaios que serão realizados com dispositivo desenvolvidos consistem essencialmente na determinação da camada semirredutora e da caracterização da filtração com equivalência de qualidade em mmAl dos materiais que interceptam o feixe de radiação $X$.

As cláusulas 29.201.3, 29.201.4 e 29.201.5, 29.201.6 reportam-se as cláusulas 29.201.7 e 29.201.8 respectivamente, que definem como os ensaios são realizados, assim como as cláusulas 29.201 .9 e 29.206.1, portanto apenas as cláusulas 29.201.7, 29.201.8, 29.201.9 e 29.206.1 contêm especificações e metodologias para a realização dos ensaios.

A cláusula 29.201.7 faz referência a norma IEC 606522: 1976, porém esta norma foi cancelada e substituída pela IEC 60522: 1999, que foi considerada na realização deste trabalho.

Segue na sequência a descrição individual de cada cláusula envolvida com o dispositivo de ensaio desenvolvido. 
- 29.201.3 - Filtração no conjunto-emissor de radiação $X^{[26]}$

Ensaio para determinação da filtração do conjunto-emissor de radiação $X$ que deverá ser expressa em espessura de um material de referência que, para uma tensão e forma de onda especificadas, fornece a mesma qualidade de radiação, em termos da primeira camada semirredutora. A metodologia para execução do ensaio é definida na cláusula 29.201.7.

\section{- 29.201.4 Filtração no conjunto-fonte de radiação $X^{[26]}$}

Ensaio para determinação da filtração da fonte de radiação, neste caso a fonte de radiação é o conjunto-emissor de radiação $X$, e do sistema limitador de feixe, alta-tensão . A metodologia para execução do ensaio é definida na cláusula 29.201.7.

\section{- 29.201.5 Filtração total no equipamento de raios $X^{[26]}$}

O ensaio consiste na soma da filtração determinada nos ensaios das cláusulas 29.201.3, 29.201.4 e 29.201.8.

\section{- 29.201.6 Indicação das propriedades do filtro}

O ensaio consiste apenas de uma comparação das informações marcadas e presentes nos documentos acompanhantes dos equipamentos de raios $X$ para diagnóstico médico, com os valores encontrados nos ensaios das clausulas 29.201.3, 29.201.4 e 29.201.8.

\section{- 29.201.7 Ensaio para filtração por materiais irremovíveis}

Ensaio para determinação da filtração realizada por materiais irremovíveis num conjunto emissor de radiação $X$, acrescentando os valores da filtração com equivalência de qualidade de cada uma das camadas não removíveis do material que intercepta o feixe de radiação X. Se a informação da filtração não puder ser obtida, a filtração com equivalência de qualidade deverá ser determinada de acordo com os Itens 4 e 5 da norma IEC 60522:1999. 
- 29.201.8 Ensaio para filtros adicionais e materiais (que interceptam o feixe de radiação $X$ )

Ensaio para determinação da filtração com equivalência de qualidade dos filtros adicionais e dos materiais que interceptam o feixe de radiação $X$, formando parte da filtração total sob condições de feixe estreito, com a espessura de alumínio que resulte na mesma primeira CSR como o material submetido ao ensaio.

\section{- 29.201.9. Ensaio para determinação da CSR}

Ensaio para determinação da primeira CSR sob condições de feixe estreito, com o equipamento de raios $X$ operando em valores selecionados de tensão dentro da faixa operacional adequada especificada, indicada na segunda coluna da Tabela 204 da ABNT NBR IEC 60601-1-3: 2001, com parâmetros de aplicação de carga correspondentes a faixa de utilização normal.

\section{- 29.206.1 Atenuação por itens no feixe de radiação $X$}

O equivalente de atenuação dos itens relacionados na tabela 206 da ABNT NBR IEC 60601-1-3: 2001, não devem exceder os valores máximos aplicáveis, apresentados na tabela 206, quando fizerem parte do equipamento de raios $X$ e forem localizados na passagem do feixe de radiação $X$ entre o paciente e o receptor de imagem como mostra a Figura 55.

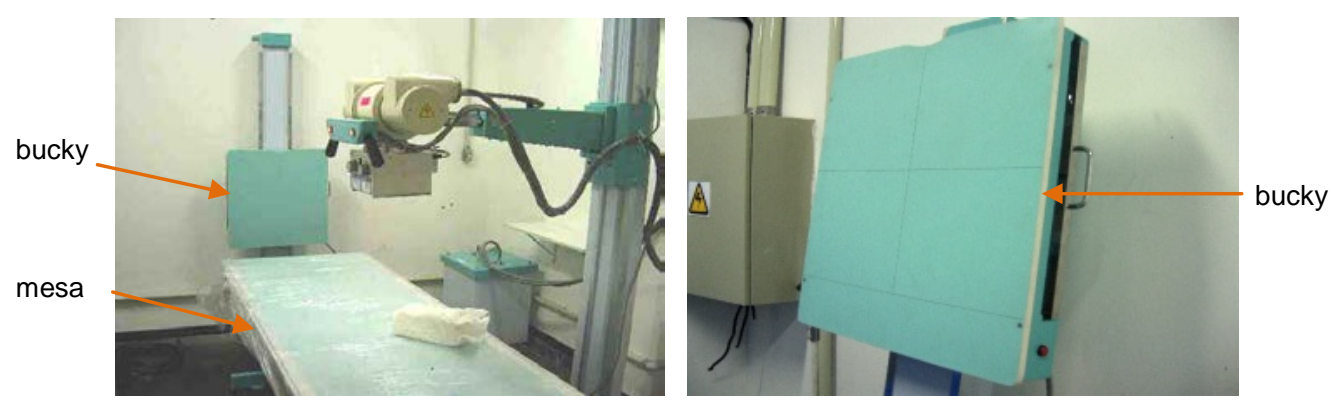

Figura 55 - Exemplo de materiais, mesa e bucky mural, interpostos entre o paciente e receptor de imagem de radiação $X$ 


\subsubsection{Estar de acordo com a ABNT NBR ISO IEC 17025: 2005}

A STEEE e a STDTS são laboratórios acreditados pelo INMETRO de acordo com requisitos da norma ABNT NBR ISO IEC 17025: $2005^{\text {[60] }}$ que trata da qualidade dos serviços de laboratórios de ensaio e calibração incluindo, como fator de extrema importância para este trabalho, os aspectos metrológicos que afetam diretamente as medições realizadas pelos laboratórios, desta forma todas as medições foram realizadas com dispositivos e métodos calibrados e/ou validados para garantir a qualidade dos resultados.

A STEEE foi o primeiro laboratório do Brasil a ser acreditado em 1995 e é o único laboratório do Brasil acreditado para realizar ensaios em equipamentos de raios $X$ para diagnóstico médico. $O$ dispositivo fará parte do escopo de acreditação da STEEE junto a CGCRE/INMETRO, desta forma o mesmo deve atender a todos os requisitos da ABNT NBR ISO IEC 17025: 2005.

A validação pelo qual o dispositivo foi submetido levou em conta todos os requisitos aplicáveis da norma citada, o que pode ser concluído que, uma vez que o dispositivo esteja devidamente validado automaticamente estará em conformidade com os requisitos ABNT NBR ISO IEC 17025: 2005, sendo validado neste trabalho.

\subsubsection{Segurança, otimização e incerteza de medição}

O dispositivo de ensaio foi construído de tal forma a minimizar a interação com o operador, preservando o mesmo dos riscos associados à exposição à radiação $X$. A otimização está presente na proposta de automação do dispositivo trocador de filtros e com a interação do mesmo com o sistema de medição de forma a minimizar o tempo de ensaio. Com a interação do usuário reduzida e com a automação proposta o fator humano como componente da incerteza de medição será desprezado. 


\subsubsection{Questão ambiental - reciclagem de componentes (Drives de CD)}

$\mathrm{Na}$ concepção do projeto do dispositivo trocador de filtros optou-se inicialmente por uma roda de filtros motorizada para a seleção do filtro desejado, que incluiria o desenvolvimento da roda de filtros, e aquisição de um sistema para motorização da roda (motores, drivers e sensores).

$\mathrm{Na}$ opção escolhida, utilizando-se um drive de $\mathrm{CD}$ fora de uso (inapto para leitura de mídia), mas funcional nos aspectos mecânicos (extensão e retração da "bandeja" onde a mídia é colocada), vislumbrou-se a possibilidade da utilização de um conjunto desses dispositivos, que seriam descartados, em substituição da roda de filtros o que, após a validação do sistema, mostrou total funcionalidade.

O propósito desta dissertação foi alcançado com a proposta da reciclagem, houve economia financeira com relação ao cancelamento do desenvolvimento da roda de filtros e houve contribuição com a questão ambiental, pois um dos principais problemas enfrentados hoje em dia com essa questão é a reciclagem de equipamentos eletrônicos.

\subsubsection{Método para determinação da atenuação dos materiais segundo a IEC 60522:1999}

O dispositivo de ensaio foi desenvolvido para atender a metodologia e requisitos da IEC 60522: 1999, levando em consideração também os requisitos e limites estabelecidos pela ABNT NBR IEC 60601-1-3: 2001.

A IEC 60522: 1999 é aplicada ao conjunto fonte de radiação - X para a determinação da filtração inerente com equivalência de qualidade de amostras dos materiais fixos de maneira permanente, utilizados na construção do tubo de raios $X$ e dos materiais que interceptam o feixe de radiação $X$, sendo que tais materiais fazem parte do conjunto formado pelo emissor de radiação $X$ (cúpula de proteção radiológica com o tubo de raios $X$ inserido) e pelo dispositivo limitador de feixe. 
As amostras a serem ensaiadas podem ser compostas para replicar a combinação dos materiais e suas espessuras, como efetivamente utilizados na construção do conjunto fonte de radiação $X$. Alternativamente, a filtração inerente pode ser determinada a partir de medições em amostras dos materiais de maneira individual, sendo que o material de referência deve ser o mesmo para cada amostra e o resultado da determinação é válido somente para uma determinada combinação de materiais.

Para a realização dos ensaios são necessárias condições especiais para a geração do feixe de radiação $X$. Tais condições são especificadas na Tabela 14 que relaciona os requisitos de cada ensaio com o gerador de referência que foi utilizado na validação do dispositivo de ensaio. 
Tabela 14- Características do Gerador de raios X exigidas pelas normas

\begin{tabular}{|c|c|c|c|c|c|c|}
\hline \multicolumn{7}{|c|}{ Características do Gerador de raios X exigidas pelas normas } \\
\hline \multirow{2}{*}{$\begin{array}{l}\text { Características do } \\
\text { gerador de raios } X\end{array}$} & \multirow[b]{2}{*}{ Requisitos IEC 60522: 1999} & \multicolumn{4}{|c|}{ ABNT NBR IEC 60601-1-3: 2001} & \multirow{2}{*}{$\begin{array}{l}\text { Gerador de } \\
\text { raios X de } \\
\text { referência }\end{array}$} \\
\hline & & 29.201.7 & 29.201.8 & 29.201 .9 & 29.206 & \\
\hline Tubo de raios- $X$ & $\begin{array}{l}\text { Tubo com janela de berílio } \\
\text { quando o ensaio for realizado } \\
\text { com composição de materiais }\end{array}$ & $\begin{array}{c}\text { De acordo com a IEC 60522: } \\
1999\end{array}$ & NE & NE & NE & $\begin{array}{l}\text { Janela de } \\
\text { berílio }\end{array}$ \\
\hline Alvo & $\begin{array}{l}\text { Mesmo material que o } \\
\text { equipamento sob ensaio } \\
\text { Não há exigência da } \\
\text { angulação }\end{array}$ & $\begin{array}{l}\text { De acordo com a IEC 60522: } \\
1999\end{array}$ & NE & NE & NE & Tungstênio \\
\hline $\begin{array}{l}\text { Tensão do tubo de } \\
\text { raios } X\end{array}$ & $\begin{array}{l}75 \text { kV ou aproximadamente } \\
\text { metade da tensão nominal do } \\
\text { tubo de raios } X \text {, o que for maior }\end{array}$ & $\begin{array}{c}70 \mathrm{kV} \text { se a tensão nominal do } \\
\text { tubo de raios } X \text { for maior que } \\
70 \mathrm{kV} \text {, outros casos a tensão } \\
\text { nominal do tubo de raios } X\end{array}$ & $70 \mathrm{kV}$ & $\begin{array}{l}\text { Dentro da faixa } \\
\text { operacional do } \\
\text { equipamento } \\
\text { sob ensaio }\end{array}$ & $\begin{array}{l}\text { 30kV para } \\
\text { mamografico } \\
100 k V \text { não } \\
\text { mamografico }\end{array}$ & $15-320 \mathrm{kV}$ \\
\hline Forma de onda & $\begin{array}{l}\text { De acordo com o equipamento } \\
\text { ensaiado }\end{array}$ & $\begin{array}{l}\text { De acordo com a IEC 60522: } \\
1999\end{array}$ & NE & NE & NE & $\begin{array}{c}\text { Alta } \\
\text { freqüência - } \\
40 \mathrm{kHz}\end{array}$ \\
\hline $\begin{array}{l}\text { Ondulação da } \\
\text { tensão do tubo de } \\
\text { raios X }\end{array}$ & $<10 \%$ & $<10 \%$ & $<10 \%$ & NE & NE & $<3 \%$ \\
\hline Critério de avaliação & $\pm 30 \%$ do valor declarado & $\begin{array}{l}\text { De acordo com a IEC 60522: } \\
1999\end{array}$ & NE & Tabela 204 & Tabela 206 & \\
\hline
\end{tabular}


O detector de radiação deve possuir uma resposta que não varie significativamente ao longo da faixa de energia envolvida. Os materiais de referência devem ser alumínio com 99,9\% de pureza ou superior ou cobre com pelo menos $99,9 \%$ de pureza ou superior. Neste trabalho foram utilizados filtros de alumínio com 99,9\% de pureza.

O método de medição definido pela IEC 60522:1999 estabelece que a primeira CSR deve ser medida sob condições de feixe estreito com a amostra colocada próximo ao ponto focal. Deve ser determinada a espessura do material de referência que é necessário para produzir o mesmo valor da CSR nas mesmas condições de feixe.

O valor da espessura encontrada do material de referência é a filtração com equivalência de qualidade da amostra. Se a amostra é um composto (agrupamento de materiais), representando todos os materiais que compõem a filtração inerente, o resultado é também o valor da filtração inerente do conjunto-emissor de radiação X. A Figura 13 mostra os materiais que compõem a filtração inerente de um conjunto fonte de radiação $X$.

O critério para avaliação do resultado é a comparação entre o valor declarado de filtração inerente pelo fabricante e o valor medido determinado nos ensaio. A conformidade com a IEC 60522:1999 será atestada se o valor medido não é menor e não excede o valor declarado em mais que 30\%.

\subsubsection{Método para determinação da CSR}

Diversas metodologias podem ser adotadas para a determinação da CSR's em feixes com espectro contínuo ${ }^{[61]}$, todas elas, no entanto, constituem basicamente no ajuste de uma função matemática que possa descrever o comportamento da relação entre a intensidade do feixe (ou número de fótons) de radiação $X$ e espessura de material absorvedor. 
O ajuste de funções matemáticas exige, no entanto, várias considerações relacionadas à qualidade do resultado (teste de $\chi^{2}$, avaliação de resíduos ponderados, etc.) para que se possa confiar nos resultados posteriormente interpolados. Isso normalmente demanda tempo, exige muitas vezes ferramentas complexas de ajuste e implica em maior complexidade na determinação das incertezas dos valores encontrados. Além disso, exige grande esforço na criação de metodologias que reduzam as dificuldades de padronização dos métodos.

Desta forma, a maneira encontrada para atender a estes requisitos foi o emprego de uma função de interpolação entre dois pontos mais próximos aos valores desejados de CSR's ou espessuras equivalentes.

Este processo pode ser feito por uma interpolação linear simples ou interpolação logarítmica, o que permitiu a elaboração de um programa computacional envolvendo os dois processos de ajuste, garantindo a reprodutibilidade da metodologia de cálculo e ainda o tratamento das fontes de incerteza envolvidas no processo.

A tela de entrada deste programa pode ser visto na Figura 56. Para que fosse possível viabilizar as metodologias de cálculo das CSR's foi desenvolvido um programa em linguagem Java, na plataforma de domínio público Netbeans 4.1 intitulado HVLCalc (HVLCalc.jar) ${ }^{[17]}$. Na Tabela 15 estão apresentadas as fontes de incerteza do software HVLCalc.

O software HVLCalc foi desenvolvido e validado por BOTTARO [17] utilizando o método proposto por GILMORET e CRANLEY [62], através de comparações entre o método de Archer ${ }^{[61]}$ e através do estudo realizado por GUIMARÃES ${ }^{[63]}$.

Para a utilização do software HVLCalc é necessário que os filtros utilizados respeitem a codificação interna do software, pois o mesmo possui o registros das incertezas de cada filtro, sendo que tais incertezas são utilizadas nos cálculos de interpolação utilizados para determinar a CSR. O detalhamento da codificação é dado no item 4.2.13. 


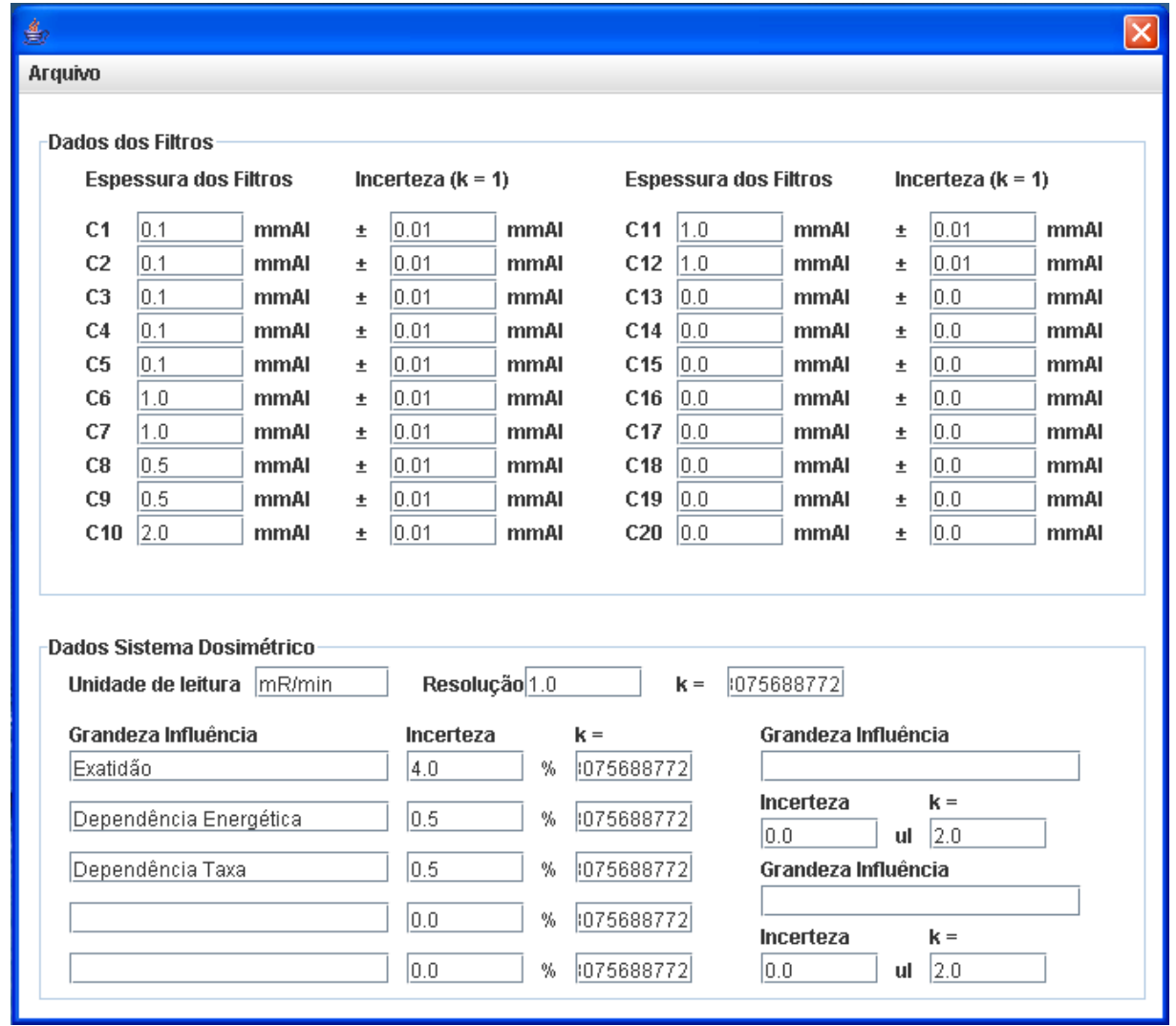

Figura 56 - Tela de entrada de erros do programa HVLCalc.jar

Tabela 15 - Fontes de incerteza utilizadas no software HVLCalc.jar

\begin{tabular}{|l|c|c|c|c|}
\hline \multicolumn{1}{|c|}{ Fonte da Incerteza } & Tipo & Distribuição & Divisor & Incerteza (\%) \\
\hline Filtro de alta pureza C1 & B & Normal & 2 & 0,002 \\
\hline Filtro de alta pureza C2 & B & Normal & 2 & 0,001 \\
\hline Filtro de alta pureza C3 & B & Normal & 2 & 0,002 \\
\hline Filtro de alta pureza C4 & B & Normal & 2 & 0,004 \\
\hline Filtro de alta pureza C6 & B & Normal & 2 & 0,002 \\
\hline Filtro de alta pureza C7 & B & Normal & 2 & 0,005 \\
\hline Filtro de alta pureza C8 & B & Normal & 2 & 0,001 \\
\hline Filtro de baixa pureza C1 & B & Normal & 2 & 0,007 \\
\hline Filtro de baixa pureza C3 & B & Normal & 2 & 0,004 \\
\hline Filtro de baixa pureza C4 & B & Normal & 2 & 0,002 \\
\hline Filtro de baixa pureza C5 & B & Normal & 2 & 0,007 \\
\hline Filtro de baixa pureza C6 & B & Normal & 2 & 0,005 \\
\hline Filtro de baixa pureza C7 & B & Normal & 2 & 0,003 \\
\hline Filtro de baixa pureza C10 & B & Normal & 2 & 0,003 \\
\hline $\begin{array}{l}\text { Exatidão (eletrômetro e Câmara de ionização } \\
\text { 6cc) }\end{array}$ & A & Retangular & $\sqrt{3}$ & 4,0 \\
\hline $\begin{array}{l}\text { Dependência Energética (eletrômetro e Câmara } \\
\text { de ionização 6cc) }\end{array}$ & A & Retangular & $\sqrt{3}$ & 0,5 \\
\hline $\begin{array}{l}\text { Dependência Taxa (eletrômetro e Câmara de } \\
\text { ionização 6cc) }\end{array}$ & A & Retangular & $\sqrt{3}$ & 0,5 \\
\hline
\end{tabular}


O software "HVLcalc", foi incorporado a o software de controle do dispositivo de ensaio desenvolvido, ver item 784.1.3.9, permitindo a otimização dos procedimentos de determinação da CSR e da filtração com equivalência de qualidade em mmAl dos materiais que interceptam o feixe de Raios $\mathrm{X}$, Tabela 16 e Tabela 17.

\subsubsection{Procedimento utilizado pela STEEE para determinação da CSR}

A Metodologia utilizada pela STEEE para a determinação da CSR está definida no procedimento 2007LS01PR004Y - procedimento de ensaio para determinação da primeira CSR ${ }^{[64]}$.

O objetivo principal deste trabalho, como dito anteriormente, é otimizar tal procedimento nos termos da sua execução no que tange a automação e a segurança do técnico que realiza o ensaio.

A proposta principal do dispositivo de ensaio é a realização dos ensaios para determinação da CSR e de atenuação dos materiais que compõem a filtração inerente e dos materiais que interceptam o feixe de radiação $X$ até a superfície receptora de imagem.

$\mathrm{Na}$ proposta apresentada tais ensaios devem ser realizados de maneira rápida respeitando os critérios normativos envolvidos e com a menor interação possível do técnico que realiza o ensaio, a interação compreende:

- Montagem dos ensaios

- A entrada e saída da sala radiológica para a realização dos ensaios

Segue na Tabela 16 uma comparação entre os passos do procedimento de ensaio 2007LS01PR004Y realizado sem e com o dispositivo de ensaio desenvolvido.

Legenda:

- operações manuais

- operação informatizada

- interação com a sala radiológica

- Melhoria efetivada

: - Passo Eliminado 
Tabela 16 - Comparação da metodologia sem o dispositivo desenvolvido e com o dispositivo desenvolvido

\begin{tabular}{|c|c|c|c|}
\hline Passos do procedimento realizado atualmente & Legenda & $\begin{array}{c}\text { Procedimento realizado atualmente utilizando o dispositivo } \\
\text { desenvolvido }\end{array}$ & Legenda \\
\hline 1. Montagem do setup de ensaio & $m / 8$ & \multirow{2}{*}{$\begin{array}{l}\text { Passos } 1 \text { e } 2 \text { eliminados, uma vez que o dispositivo possui } \\
\text { geometria fixa. }\end{array}$} & \multirow[t]{2}{*}{$\stackrel{9}{x}$} \\
\hline 2. Ajuste da geometria de acordo com IEC 61267; & $\operatorname{ma}$ & & \\
\hline 3. Preparação e ajuste da instrumentação; & M 8 & $\begin{array}{l}\text { Passo } 3 \text { eliminado, a instrumentação (sistema de aquisição) } \\
\text { utilizada é dedicada ao dispositivo desenvolvido, desta forma a } \\
\text { instrumentação esta pronta para a utilização. }\end{array}$ & $\ddot{8}$ \\
\hline $\begin{array}{l}\text { 4. Ajuste da colimação para estabelecer a condição } \\
\text { de feixe estreito; }\end{array}$ & m 8 & $\begin{array}{l}\text { O ajuste é necessário apenas para o ensaio de determinação } \\
\text { da camada semirredutora do equipamento de raios } X \text { a ser } \\
\text { ensaiado, para o ensaio de atenuação dos materiais a } \\
\text { colimação é mantida na condição de feixe estreito. }\end{array}$ & 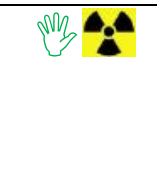 \\
\hline 5. Centralização do sistema de medição com ecrã; & $\left(\frac{1}{3}\right.$ & Centralização do sistema de medição com ecrã; & $m_{3}^{4}$ \\
\hline $\begin{array}{l}\text { 6. Preparação da planilha de ensaio para entrada } \\
\text { manual de dados em uma tabela presente na } \\
\text { mesma; }\end{array}$ & $\square$ & $\begin{array}{l}\text { Passo } 6 \text { eliminado, pois os dados inseridos automaticamente na } \\
\text { planilha do MS Excel }\end{array}$ & $\dot{x}$ \\
\hline $\begin{array}{l}\text { 7. Realização de } 5 \text { irradiações sem filtração alguma } \\
\text { para determinar a radiação nominal, } I_{0} ;\end{array}$ & m $\square$ & $\begin{array}{l}\text { Realização de } 5 \text { irradiações sem filtração alguma para } \\
\text { determinar a radiação nominal, } ।_{0} ;\end{array}$ & Mh \\
\hline $\begin{array}{l}\text { 8. Digitar os valores de Kerma no ar fornecidos pelo } \\
\text { display da câmara de ionização para a tabela da } \\
\text { planilha de ensaio; }\end{array}$ & Wh & $\begin{array}{l}\text { Passo } 8 \text { eliminado, pois os dados inseridos automaticamente na } \\
\text { planilha do MS Excel }\end{array}$ & $\ddot{x}$ \\
\hline
\end{tabular}


Tabela 16 - Comparação da metodologia sem o dispositivo desenvolvido e com o dispositivo desenvolvido

\begin{tabular}{|c|c|c|c|}
\hline Passos do procedimento realizado atualmente & Legenda & $\begin{array}{l}\text { Procedimento realizado atualmente utilizando o dispositivo } \\
\text { desenvolvido }\end{array}$ & Legenda \\
\hline $\begin{array}{l}\text { 9. Instalar suporte para filtros uma filtração de } \\
\text { alumínio com valor correspondente a tensão } \\
\text { selecionada (tabela } 204 \text { - ABNT NBR IEC 60601- } \\
\text { 1-3); }\end{array}$ & $m^{m} / 8$ & $\begin{array}{l}\text { Passo } 9 \text { eliminado, pois o dispositivo utiliza o trocador de filtros } \\
\text { controlado remotamente. }\end{array}$ & $\ddot{x}$ \\
\hline $\begin{array}{l}\text { 10. Realizar uma irradiação e os passos seguintes: } \\
\text { a. Se o valor da radiação, I, medido for I > I0/2, } \\
\text { adicione gradualmente filtros de } 0,1 \mathrm{~mm} \text { e realize } \\
\text { outras irradiações até que } \mathrm{I}<\mathrm{I0} / 2 \text {; } \\
\text { b. Se o valor de radiação, } \mathrm{I} \text {, medido for } \mathrm{I}<\mathrm{I0} / 2 \text {, } \\
\text { retire gradualmente filtros de } 0,1 \mathrm{~mm} \text { e realize } \\
\text { outras irradiações até que } \mathrm{I}>\mathrm{I} / 2 / 2 \text {; }\end{array}$ & 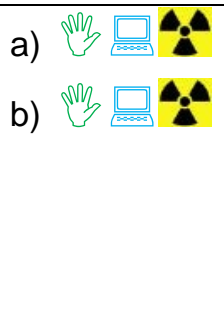 & $\begin{array}{l}\text { No procedimento 2007LS01PR004Y os filtros são trocados } \\
\text { manualmente, o que não ocorre com o dispositivo desenvolvido } \\
\text { que utiliza o trocador de filtros controlado remotamente não } \\
\text { havendo a necessidade de entrar e sair da sala radiológica para } \\
\text { trocar os filtros. }\end{array}$ & mb $\square$ \\
\hline $\begin{array}{l}\text { 11. Realizar } 5 \text { irradiações com o valor mínimo de } \\
\text { filtração para I < I0/2; }\end{array}$ & $M / \square$ & $\begin{array}{l}\text { No procedimento 2007LS01PR004Y os filtros são trocados } \\
\text { manualmente, o que não ocorre com o dispositivo desenvolvido } \\
\text { que utiliza o trocador de filtros controlado remotamente não } \\
\text { havendo a necessidade de entrar e sair da sala radiológica para } \\
\text { trocar os filtros. }\end{array}$ & Mm $\square$ \\
\hline $\begin{array}{l}\text { 12. Realizar } 5 \text { irradiações com o máximo valor de } \\
\text { filtração para que I > I0/2; }\end{array}$ & Wh $\square$ & $\begin{array}{l}\text { No procedimento 2007LS01PR004Y os filtros são trocados } \\
\text { manualmente, o que não ocorre com o dispositivo desenvolvido } \\
\text { que utiliza o trocador de filtros controlado remotamente não } \\
\text { havendo a necessidade de entrar e sair da sala radiológica para } \\
\text { trocar os filtros. }\end{array}$ & $m^{m} \square$ \\
\hline $\begin{array}{l}\text { 13. Transferir os valores para a tabela da planilha } \\
\text { (Cláusula 29.201.9 - ABNT NBR IEC 60601-1-3); }\end{array}$ & my & \multirow[t]{2}{*}{$\begin{array}{l}\text { Passo } 13 \text { eliminado, pois os dados inseridos automaticamente } \\
\text { na planilha do MS Excel }\end{array}$} & \multirow[t]{2}{*}{ 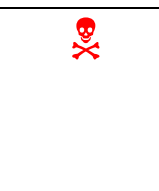 } \\
\hline $\begin{array}{l}\text { 14. Selecionar os campos da tabela preenchida no } \\
\text { MS Excel com os dados dos ensaios; }\end{array}$ & my $\square$ & & \\
\hline
\end{tabular}


Tabela 16 - Comparação da metodologia sem o dispositivo desenvolvido e com o dispositivo desenvolvido

\begin{tabular}{|c|c|c|c|}
\hline Passos do procedimento realizado atualmente & Legenda & $\begin{array}{c}\text { Procedimento realizado atualmente utilizando o dispositivo } \\
\text { desenvolvido }\end{array}$ & Legenda \\
\hline $\begin{array}{l}\text { 15. A tabela deve ser colada no MS Word e } \\
\text { convertida em texto; }\end{array}$ & MI $\square$ & $\begin{array}{l}\text { Passo eliminado o software "HVLcalc" foi incorporado ao } \\
\text { software de controle do dispositivo de ensaio }\end{array}$ & : \\
\hline $\begin{array}{l}\text { 16. Como os valores da tabela convertida } \\
\text { apresentarão vírgulas, as mesmas deverão ser } \\
\text { substituídas por pontos para que o software } \\
\text { HVLcalc possa interpreta-los; }\end{array}$ & Mb $\square$ & $\begin{array}{l}\text { Passo eliminado o software "HVLcalc" foi incorporado ao } \\
\text { software de controle do dispositivo de ensaio }\end{array}$ & $\ddot{x}$ \\
\hline $\begin{array}{l}\text { 17. O arquivo convertido com os dados dos ensaios } \\
\text { deve ser salvo no formato txt; }\end{array}$ & M $\square$ & $\begin{array}{l}\text { Passo eliminado o software "HVLcalc" foi incorporado ao } \\
\text { software de controle do dispositivo de ensaio }\end{array}$ & : \\
\hline $\begin{array}{l}\text { 18. O software HVLcalc deverá ser aberto para que a } \\
\text { tabelas com as incertezas dos filtros utilizados } \\
\text { sejam carregadas; }\end{array}$ & Mb $\square$ & $\begin{array}{l}\text { Passo eliminado o software "HVLcalc" foi incorporado ao } \\
\text { software de controle do dispositivo de ensaio }\end{array}$ & $\dot{x}$ \\
\hline $\begin{array}{l}\text { 19. Com o software HVLcalc aberto, os dados dos } \\
\text { ensaios no formato txt deverão ser carregados } \\
\text { para que programa efetue o calculo da CSR; }\end{array}$ & $m$ & $\begin{array}{l}\text { Passo eliminado o software "HVLcalc" foi incorporado ao } \\
\text { software de controle do dispositivo de ensaio }\end{array}$ & $\ddot{x}$ \\
\hline 20. Salvar os dados. & m $\square$ & Salvar os dados. & 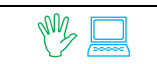 \\
\hline
\end{tabular}




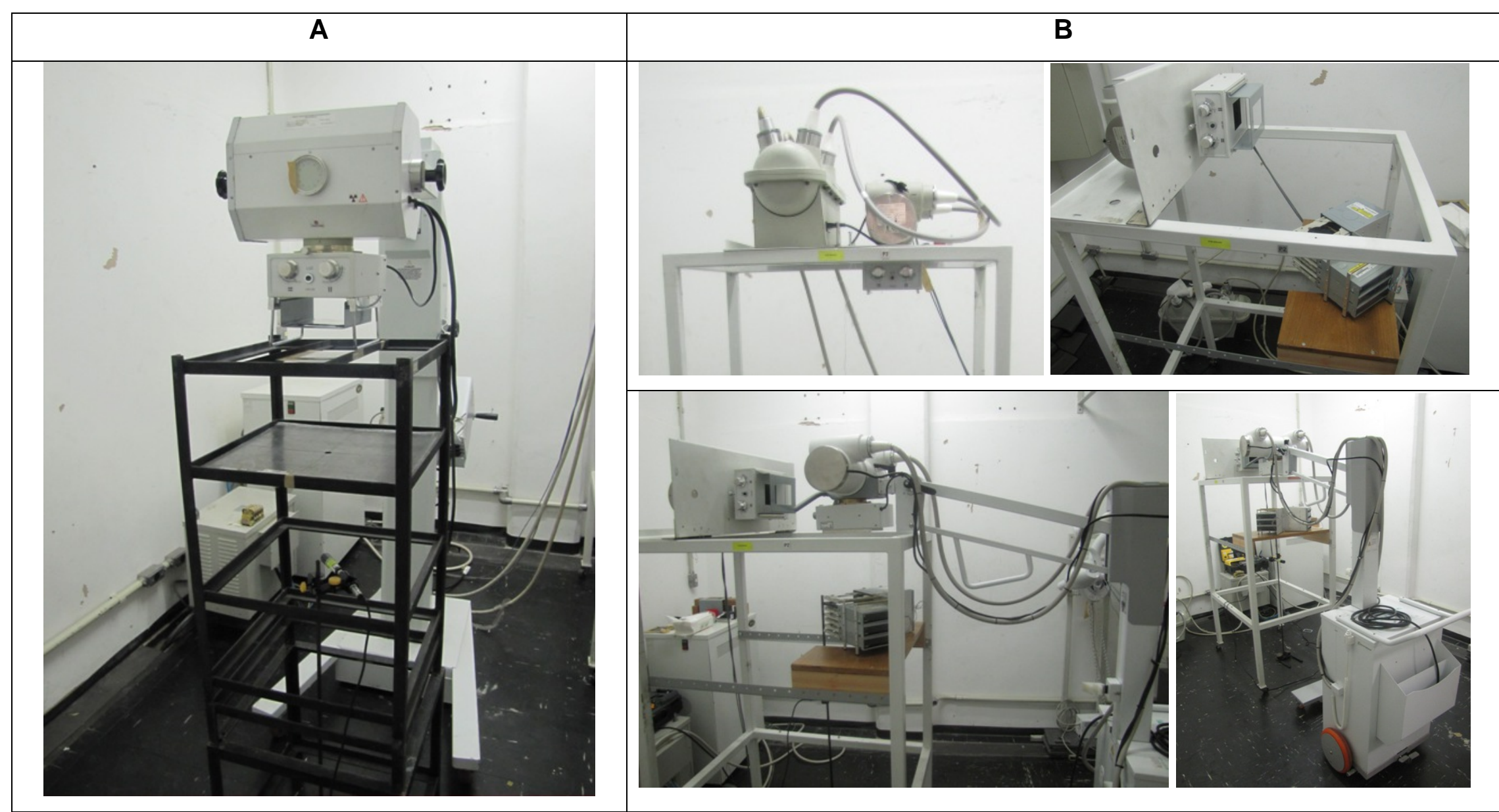

Figura 57 - (A) Imagem do arranjo tradicional e (B) do dispositivo de ensaio desenvolvido para determinação da CSR 


\subsubsection{Analise da comparação}

A metodologia do procedimento 2007LS01PR004Y apresenta uma sequência aproximada de 20 passos para a sua realização que pode ser mais extensa se levarmos em conta que os passos 11 e 12 dependem do resultado do ensaio. Constata-se também 12 interações ou mais (passos 11 e 12) entre o técnico de ensaio e a sala radiológica.

\subsubsection{Procedimento utilizado pela STEEE para determinação da filtração dos materiais com equivalência de qualidade em alumínio}

Para a determinação da atenuação dos materiais que compõem a filtração inerente e dos materiais que interceptam o feixe de radiação $X$ até a superfície receptora de imagem, os passos de 1 a 8 do procedimento 2007LS01PR004Y devem ser repetidos, os passos seguintes devem ser realizados:

Segue na tabela uma comparação entre os passos do procedimento de ensaio realizado com e sem o dispositivo de ensaio desenvolvido.

Legenda:

- operações manuais

- operação informatizada

- interação com a sala radiológica

- Melhoria efetivada

- Passo Eliminado 
Tabela 17 - Comparação da metodologia sem o dispositivo desenvolvido e com o dispositivo desenvolvido

\begin{tabular}{|c|c|c|c|}
\hline Passos do procedimento realizado atualmente & Legenda & $\begin{array}{l}\text { Procedimento realizado atualmente utilizando o } \\
\text { dispositivo desenvolvido }\end{array}$ & Legenda \\
\hline $\begin{array}{l}\text { 9. Colocar a amostra do material a ser ensaiada no } \\
\text { suporte }\end{array}$ & & Colocar a amostra do material a ser ensaiada no suporte & \\
\hline $\begin{array}{l}\text { 10. Realizar } 5 \text { irradiações para determinar a radiação } \\
\text { nominal, } \mathrm{I}_{0}\end{array}$ & $\square$ & Realizar 5 irradiações para determinar a radiação nominal, $\mathrm{I}_{0}$ & Mn $\square$ \\
\hline $\begin{array}{l}\text { 11. Transferir os resultados das medições para a } \\
\text { planilha do MS Excel }\end{array}$ & Wh & $\begin{array}{l}\text { Passo } 11 \text { eliminado, pois os dados inseridos } \\
\text { automaticamente na planilha do MS Excel }\end{array}$ & $\ddot{x}$ \\
\hline 12. Retirar a amostra do material & & Retirar a amostra do material & \\
\hline $\begin{array}{l}\text { 13. Realizar uma irradiação e os passos seguintes: } \\
\text { a. Se o valor da radiação, } \mathrm{I} \text {, medido for } \mathrm{I}>\mathrm{I}_{0} / 2 \text {, } \\
\text { adicione gradualmente filtros de } 0,1 \mathrm{~mm} \text { e realize } \\
\text { outras irradiações até que } \mathrm{I}<\mathrm{I}_{0} / 2 \text {; } \\
\text { b. Se o valor de radiação, } \mathrm{I} \text {, medido for } \mathrm{I}<\mathrm{I}_{0} / 2 \text {, } \\
\text { retire gradualmente filtros de } 0,1 \mathrm{~mm} \text { e realize } \\
\text { outras irradiações até que } \mathrm{I}>\mathrm{I}_{0} / 2 \text {; }\end{array}$ & $m^{4}$ & $\begin{array}{l}\text { No procedimento atual os filtros são trocados manualmente, } \\
\text { o que não ocorre com o dispositivo desenvolvido que utiliza o } \\
\text { trocador de filtros controlado remotamente não havendo a } \\
\text { necessidade de entrar e sair da sala radiológica para trocar } \\
\text { os filtros. }\end{array}$ & 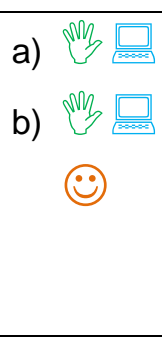 \\
\hline $\begin{array}{l}\text { 14. Transferir os resultados das medições para a } \\
\text { planilha do MS Excel; }\end{array}$ & Wh & $\begin{array}{l}\text { Passo } 14 \text { eliminado, pois os dados inseridos } \\
\text { automaticamente na planilha do MS Excel }\end{array}$ & $\ddot{x}$ \\
\hline $\begin{array}{l}\text { Repetir os passos de } 9 \text { a } 14 \text { para cada amostra de } \\
\text { material. }\end{array}$ & $m=\square$ & $\begin{array}{l}\text { Repetir os passos de } 9,10,12 \text { e } 13 \text { para cada amostra de } \\
\text { material. }\end{array}$ & \\
\hline
\end{tabular}




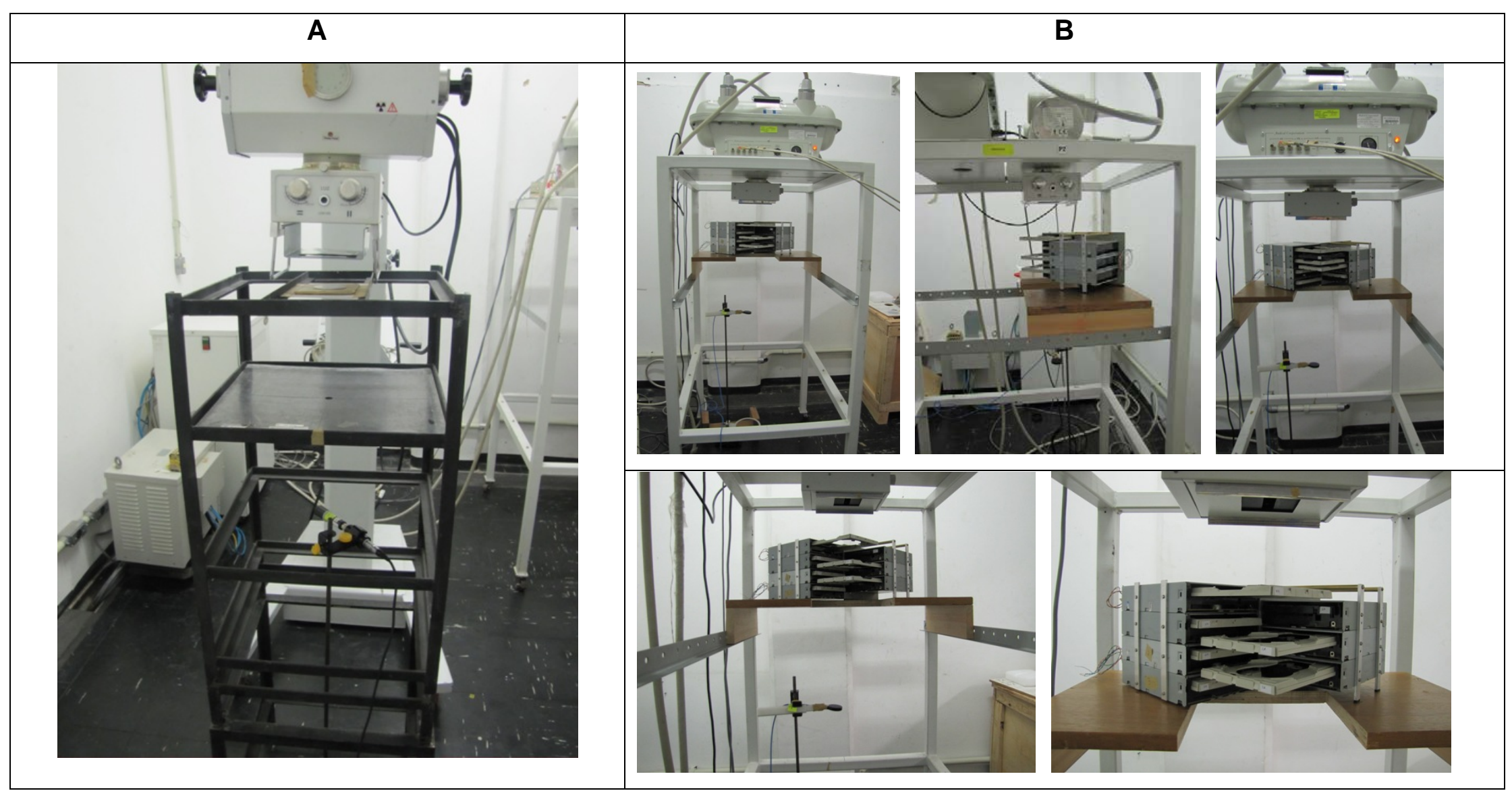

Figura 58 - (A) Imagem do arranjo tradicional e (B) do dispositivo de ensaio desenvolvido para determinação da filtração com equivalência de qualidade dos materiais 


\subsubsection{Analise da comparação}

Após a análise é verificado nitidamente a redução dos passos de execução (otimização) e de interação entre o técnico e a sala radiológica (proteção radiológica) tanto no procedimento para determinação da CSR quanto no procedimento para a verificação da atenuação dos materiais.

\subsubsection{Validação do dispositivo de ensaios}

O dispositivo trocador de filtros possui características que modificam o procedimento tradicional de determinação da CSR, pois normalmente os filtros de alta pureza são agrupados por empilhamento até que a valor inicial de kerma no ar medido seja reduzido pela metade.

No dispositivo tal empilhamento é substituído pelos drives de CD de computador onde ocorre um distanciamento entre cada filtro selecionado em função da construção e montagem do dispositivo.

Para a redução de custos foram instalados filtros de baixa pureza no dispositivo, como tais filtros não possuem a especificação de pureza necessária recomendada pelas normas (99,9\% de pureza), foi efetuada a validação do dispositivo que consiste na verificação dos fatores de influência que estão diretamente relacionados aos resultados obtidos. Na construção do dispositivo foram considerados os seguintes fatores de influência:

1. Influência do material que compõe o drive e o suporte do trocador de filtros (madeira) com relação à radiação espalhada;

2. Influência da distância entre os filtros em função da disposição na montagem nos drives do trocador de filtros;

3. Influência da posição dos filtros e da pureza para a determinação da CSR (camada semirredutora), esta validação está relacionada às clausulas 29.201.7, 29.201.8, 29.201.9 e 29.206. 


\subsubsection{Codificação do dispositivo trocador de filtros}

Para organizar os dados dos resultados da validação, o dispositivo trocador de filtros foi dividido em 2 partes , A e B, sendo que cada parte foi codificada numericamente para relacionar a posição do filtro no dispositivo. A Figura 59 ilustra a codificação utilizada.

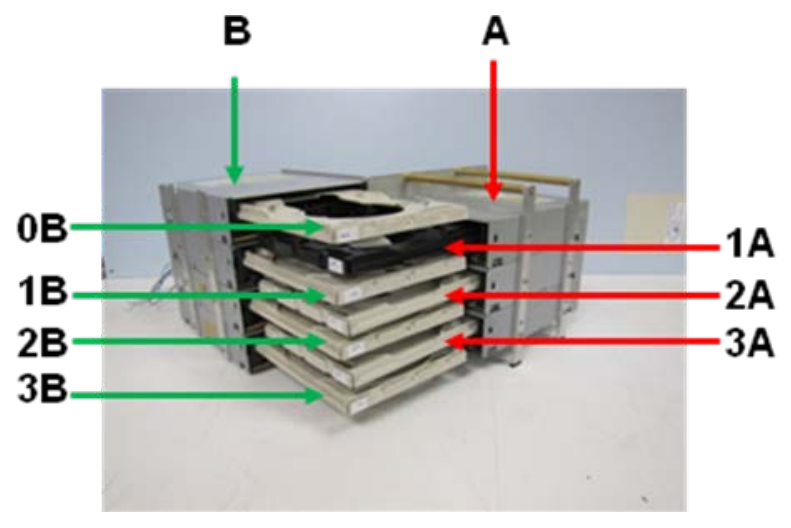

Figura 59 - Codificação do dispositivo trocador de filtros

\subsubsection{Codificação dos filtros de alta e baixa pureza}

Os filtros foram codificados de acordo com a relação dos mesmos com o Software HVLCalc, detalhado no item 4.2.7. A Tabela 18 apresenta as espessuras dos filtros de baixa e alta pureza com as suas codificações.

Tabela 18 - Codificação dos filtros de baixa e alta pureza utilizados

\begin{tabular}{|c|c|c|c|}
\hline \multicolumn{2}{|c|}{ FILTROS DE BAIXA PUREZA } & \multicolumn{2}{c|}{ FILTROS DE ALTA PUREZA } \\
\hline $\begin{array}{c}\text { Código filtros } \\
\text { utilizados }\end{array}$ & Espessura total $(\mathbf{m m})$ & $\begin{array}{c}\text { Código filtros } \\
\text { utilizados }\end{array}$ & Espessura total $(\mathbf{m m})$ \\
\hline C1 & 0,1 & C1 & 0,1 \\
\hline C3 & 0,1 & C2 & 0,1 \\
\hline C4 & 0,1 & C3 & 0,1 \\
\hline C5 & 0,1 & C4 & 0,1 \\
\hline C6 & 1 & $\mathbf{C 6}$ & 1 \\
\hline C7 & 2 & C7 & 2 \\
\hline C10 & 0,5 & C8 & 0,5 \\
\hline
\end{tabular}




\subsubsection{Metodologia para a análise dos resultados}

A análise dos resultados foi feita a partir do erro normalizado [65] que consiste na comparação de um valor de referência com o valor medido. Se o valor encontrado do erro normalizado for menor que 1 considera-se que os o valores são compatíveis, se estiver entre $\mathbf{1}$ e $\mathbf{2}$ a comparação é questionável, e se for maior que 2, a probabilidade dos valores serem iguais é desprezada.

$$
E n=\frac{V m-V r e f}{\sqrt{U^{2}{ }_{V m}+U^{2}{ }_{V r e f}}}
$$

onde:

Vm - Valor médio da medida em cada condição

Vref - Valor adotado como referência

$\boldsymbol{U}_{V \boldsymbol{m}}$ - é a incerteza expandida relatada pelo laboratório participante

$\boldsymbol{U}_{\boldsymbol{V} \text { ref-é a incerteza expandida relatada pelo laboratório de referência }}$

Os critérios de arredondamento e algarismos significativos seguiram as recomendações do Guia de Incerteza de Medição INMETRO$2003^{[66]}$. 


\section{RESULTADOS}

\subsection{Validação do dispositivo trocador de filtros com relação ao posicionamento e pureza dos filtros utilizados}

A verificação da influência da pureza dos filtros e da distância dos filtros, com relação à saída de radiação do gerador de raios $X$, posicionados nos drives das extremidades superior (posição $0 \mathrm{~B}$ ) e inferior (posição 3B) do dispositivo trocador de filtros, Figura 60, são apresentados nas Tabela 19 e Tabela 20.

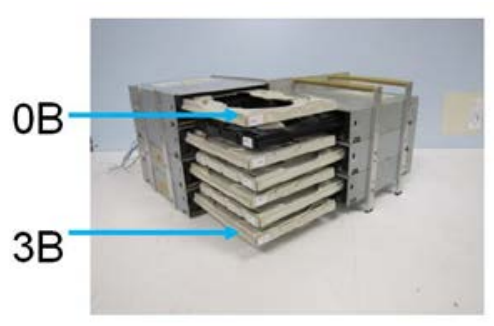

Figura 60 - Posições OB e 3B no dispositivo trocador de filtros

Tabela 19 - Verificação entre a posição OB e 3B dos filtros de Baixa pureza

\begin{tabular}{|c|c|c|c|c|}
\hline $\begin{array}{c}\text { Filtros de Baixa } \\
\text { Pureza }\end{array}$ & $\begin{array}{c}\text { Posição 0B } \\
\text { (mGy) }\end{array}$ & $\begin{array}{c}\text { Posição 3B } \\
\text { (mGy) }\end{array}$ & $\begin{array}{c}\text { Diferença 0B - 3B } \\
\text { (mGy) }\end{array}$ & U95 (\%) \\
\hline C1 & 3,695 & 3,692 & $\mathbf{0 , 0 0 2}$ & $\mathbf{4 , 0}$ \\
\hline C2 & 3,707 & 3,704 & $\mathbf{0 , 0 0 3}$ & $\mathbf{4 , 0}$ \\
\hline C3 & 3,711 & 3,709 & $\mathbf{0 , 0 0 3}$ & $\mathbf{4 , 0}$ \\
\hline C4 & 3,708 & 3,705 & $\mathbf{0 , 0 0 3}$ & $\mathbf{4 , 0}$ \\
\hline C6 & 2,325 & 2,329 & $\mathbf{0 , 0 0 4}$ & $\mathbf{4 , 0}$ \\
\hline C7 & 1,521 & 1,522 & $\mathbf{0 , 0 0 1}$ & $\mathbf{4 , 0}$ \\
\hline C8 & 2,897 & 2,886 & $\mathbf{0 , 0 1 1}$ & $\mathbf{4 , 0}$ \\
\hline
\end{tabular}

Tabela 20 - Verificação entre a posição 0B e 3B dos filtros de Alta pureza

\begin{tabular}{|c|c|c|c|c|}
\hline Filtros de Alta Pureza & $\begin{array}{c}\text { Posição 0B } \\
\text { (mGy) }\end{array}$ & $\begin{array}{c}\text { Posição 3B } \\
\text { (mGy) }\end{array}$ & $\begin{array}{c}\text { Diferença 0B - 3B } \\
\text { (mGy) }\end{array}$ & U95 (\%) \\
\hline C1 & 3,706 & 3,697 & $\mathbf{0 , 0 0 9}$ & $\mathbf{4 , 0}$ \\
\hline C3 & 3,695 & 3,691 & $\mathbf{0 , 0 0 4}$ & $\mathbf{4 , 0}$ \\
\hline C4 & 3,691 & 3,705 & $\mathbf{0 , 0 1 5}$ & $\mathbf{4 , 0}$ \\
\hline C5 & 3,681 & 3,693 & $\mathbf{0 , 0 1 2}$ & $\mathbf{4 , 0}$ \\
\hline C7 & 2,303 & 2,314 & $\mathbf{0 , 0 1 0}$ & $\mathbf{4 , 0}$ \\
\hline C6 & 1,538 & 1,538 & $\mathbf{0 , 0 0 0}$ & $\mathbf{4 , 0}$ \\
\hline C10 & 2,904 & 2,913 & $\mathbf{0 , 0 1 0}$ & $\mathbf{4 , 0}$ \\
\hline
\end{tabular}


A Tabela 21e Tabela 22 apresentam a verificação da influência da pureza dos filtros nas posições $O B$ e $3 B$, respectivamente, através da comparação dos resultados de ambos.

Tabela 21 - Verificação da influência da pureza dos filtros na posição 0B através da comparação dos resultados

\begin{tabular}{|c|c|c|c|c|c|}
\hline $\begin{array}{c}\text { Filtros de Baixa } \\
\text { Pureza }\end{array}$ & $\begin{array}{c}\text { Posição 0B } \\
\text { (mGy) }\end{array}$ & $\begin{array}{c}\text { Filtros de Alta } \\
\text { Pureza }\end{array}$ & $\begin{array}{c}\text { Posição 0B } \\
\text { (mGy) }\end{array}$ & $\begin{array}{c}\text { Diferença 0B - } \\
\text { 0B (mGy) }\end{array}$ & U95 (\%) \\
\hline C1 & 3,695 & C1 & 3,706 & $\mathbf{0 , 0 1 1}$ & $\mathbf{4 , 0}$ \\
\hline C2 & 3,708 & C3 & 3,695 & $\mathbf{0 , 0 1 2}$ & $\mathbf{4 , 0}$ \\
\hline C3 & 3,711 & C4 & 3,691 & $\mathbf{0 , 0 2 1}$ & $\mathbf{4 , 0}$ \\
\hline C4 & 3,709 & C5 & 3,681 & $\mathbf{0 , 0 2 7}$ & $\mathbf{4 , 0}$ \\
\hline C6 & 2,325 & C7 & 2,303 & $\mathbf{0 , 0 2 2}$ & $\mathbf{4 , 0}$ \\
\hline C7 & 1,521 & C6 & 1,538 & $\mathbf{0 , 0 1 7}$ & $\mathbf{4 , 0}$ \\
\hline C8 & 2,897 & C10 & 2,904 & $\mathbf{0 , 0 0 7}$ & $\mathbf{4 , 0}$ \\
\hline
\end{tabular}

Tabela 22 - Verificação da influência da pureza dos filtros na posição 3B através da comparação dos resultados

\begin{tabular}{|c|c|c|c|c|c|}
\hline $\begin{array}{c}\text { Filtros de Baixa } \\
\text { Pureza }\end{array}$ & $\begin{array}{c}\text { Posição 3B } \\
\text { (mGy) }\end{array}$ & $\begin{array}{c}\text { Filtros de Alta } \\
\text { Pureza }\end{array}$ & $\begin{array}{c}\text { Posição 3B } \\
\text { (mGy) }\end{array}$ & $\begin{array}{c}\text { Diferença 3B - } \\
\text { 3B (mGy) }\end{array}$ & U95 (\%) \\
\hline C1 & 3,692 & C1 & 3,697 & $\mathbf{0 , 0 0 4}$ & $\mathbf{4 , 0}$ \\
\hline C2 & 3,704 & C3 & 3,691 & $\mathbf{0 , 0 1 3}$ & $\mathbf{4 , 0}$ \\
\hline C3 & 3,709 & C4 & 3,706 & $\mathbf{0 , 0 0 3}$ & $\mathbf{4 , 0}$ \\
\hline C4 & 3,705 & C5 & 3,693 & $\mathbf{0 , 0 1 2}$ & $\mathbf{4 , 0}$ \\
\hline C6 & 2,329 & C7 & 2,314 & $\mathbf{0 , 0 1 6}$ & $\mathbf{4 , 0}$ \\
\hline C7 & 1,522 & C6 & 1,538 & $\mathbf{0 , 0 1 6}$ & $\mathbf{4 , 0}$ \\
\hline C8 & 2,886 & C10 & 2,913 & $\mathbf{0 , 0 2 8}$ & $\mathbf{4 , 0}$ \\
\hline
\end{tabular}

A Figura 61 e Figura 62 ilustram graficamente a comparação e a diferença calculada, respectivamente, entre o posicionamento e a pureza dos filtros.

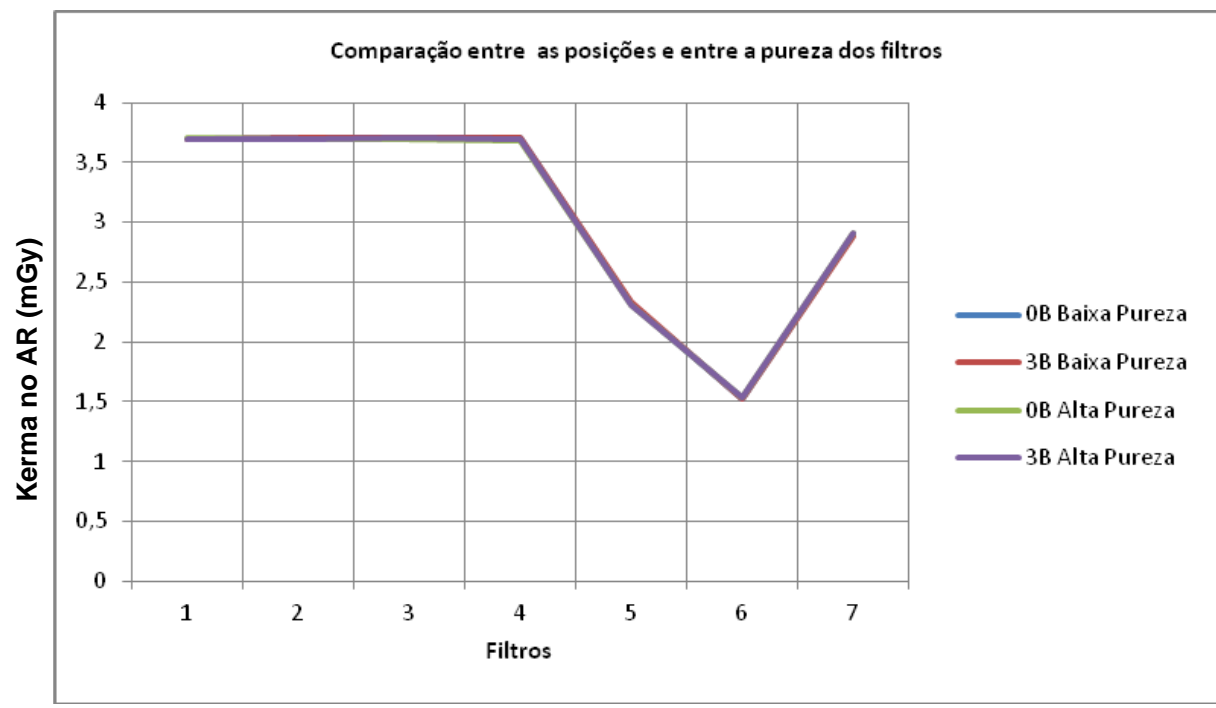

Figura 61 - Gráfico de comparação entre as posições e entre a pureza dos filtros 


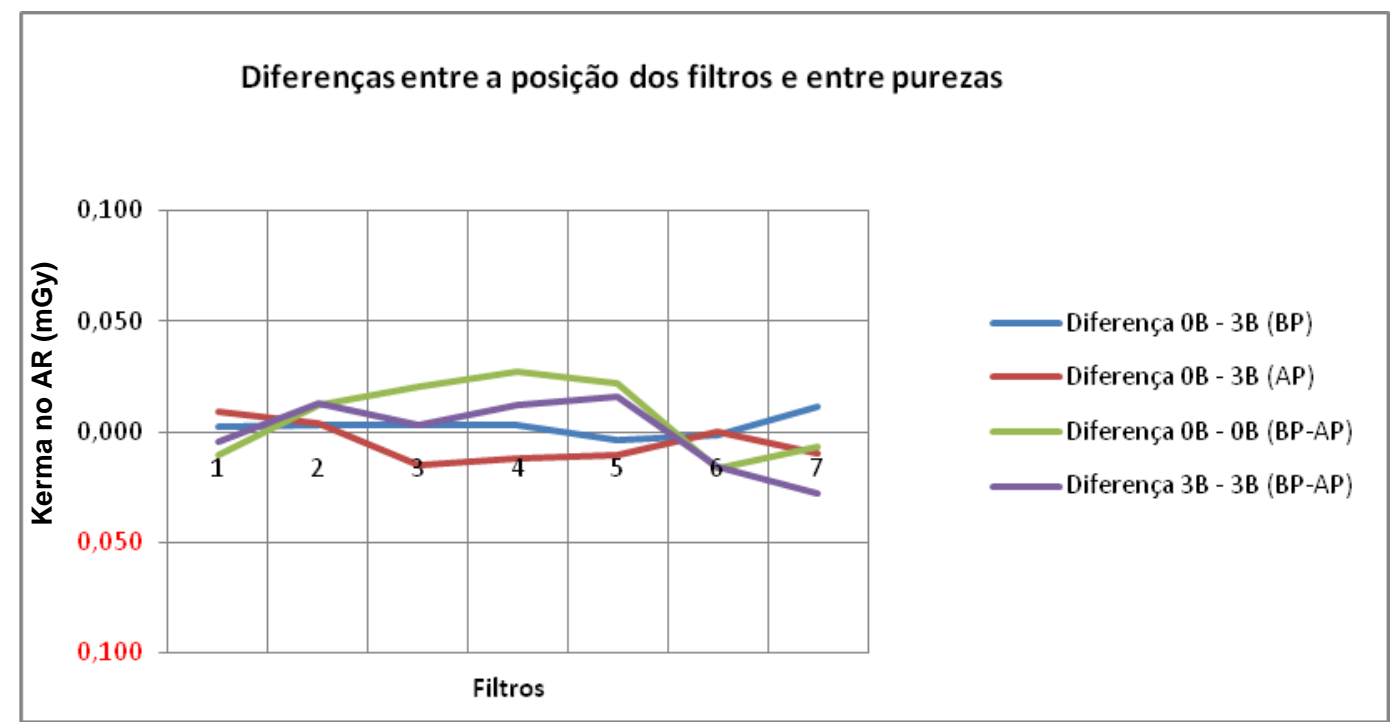

Figura 62 - Gráfico das diferenças entre a posição dos filtros e entre purezas

\subsection{Análise dos resultados}

Através dos cálculos realizados e da demonstração gráfica observa-se que a influência entre as posições $0 B$ - 3B, OB - OB e 3B-3B, para os filtros de baixa e alta pureza, é desprezível.

As medições demonstraram também que é possível utilizar os filtros de baixa pureza, pois a diferença verificada com relação aos filtros de alta pureza também é desprezível. Estudo realizado por OLIVEIRA [67] confirmou esta possibilidade,pois foram caracterizadas as qualidades de radiação para fins de calibração, RQR2, RQ6 e RQR10, utilizando filtros de alta e baixa pureza. Também foi realizada a medição dos espectros dos filtros de alta e baixa pureza, os resultados do estudo são reproduzidos na Tabela 23.

Tabela 23 - Parâmetros de raios X para filtros de alta e baixa pureza X para radiações de referencia RQR 2, RQR 6 e RQR 10.

\begin{tabular}{|c|c|c|c|c|c|c|}
\hline PARÂMETROS DO FEIXE DE RAIOS X & \multicolumn{2}{|c|}{ RQR 2} & \multicolumn{2}{|c|}{ RQR 6} & \multicolumn{2}{|c|}{ RQR 10} \\
\hline Pureza do filtro & ALTA & BAIXA & ALTA & BAIXA & ALTA & BAIXA \\
\hline Tensão do tubo de raios $x(k V)$ & \multicolumn{2}{|c|}{40,0} & \multicolumn{2}{|c|}{80,0} & \multicolumn{2}{|c|}{100,0} \\
\hline Filtro adicional (mmAl) & 2,04 & 2,31 & 3,00 & 2,81 & 3,95 & 4,08 \\
\hline CSR IEC (mmAl) & \multicolumn{2}{|c|}{1,42} & \multicolumn{2}{|c|}{3,01} & \multicolumn{2}{|c|}{6,57} \\
\hline CSR do estudo (mmAl) & 1,40 & 1,43 & 3,02 & 3,00 & 6,47 & 6,71 \\
\hline Incerteza da CSR* (\%) & 8,09 & 7,69 & 9,75 & 5,13 & 7,13 & 13,19 \\
\hline Coeficiente de homogeneidade - IEC & \multicolumn{2}{|c|}{0,81} & \multicolumn{2}{|c|}{0,69} & \multicolumn{2}{|c|}{0,72} \\
\hline Coeficiente de homogeneidade - do estudo & 0,78 & 0,80 & 0,66 & 0,69 & 0,69 & 0,69 \\
\hline Incerteza do coeficiente de homogeneidade (\%) & 11,45 & 10,87 & 13,79 & 7,26 & 10,09 & 18,66 \\
\hline
\end{tabular}

* As incertezas expandidas são dadas para um fator de abrangência de 2 a 95,45\% nível de confiança. 
A Figura 63, Figura 64 e Figura 65 mostram os espectros de energia RQR2, RQR6 e RQR10, respectivamente, que foram obtidos com o espectrômetro calibrado. As linhas azul e vermelho referem-se às qualidades com filtros de alta e baixa pureza, respectivamente. Segundo OLIVEIRA (2008) os resultados mostraram que os espectros foram bastante semelhantes e sugerem que filtros de alumínio de baixa pureza $(99,425 \%)$ podem ser utilizados.

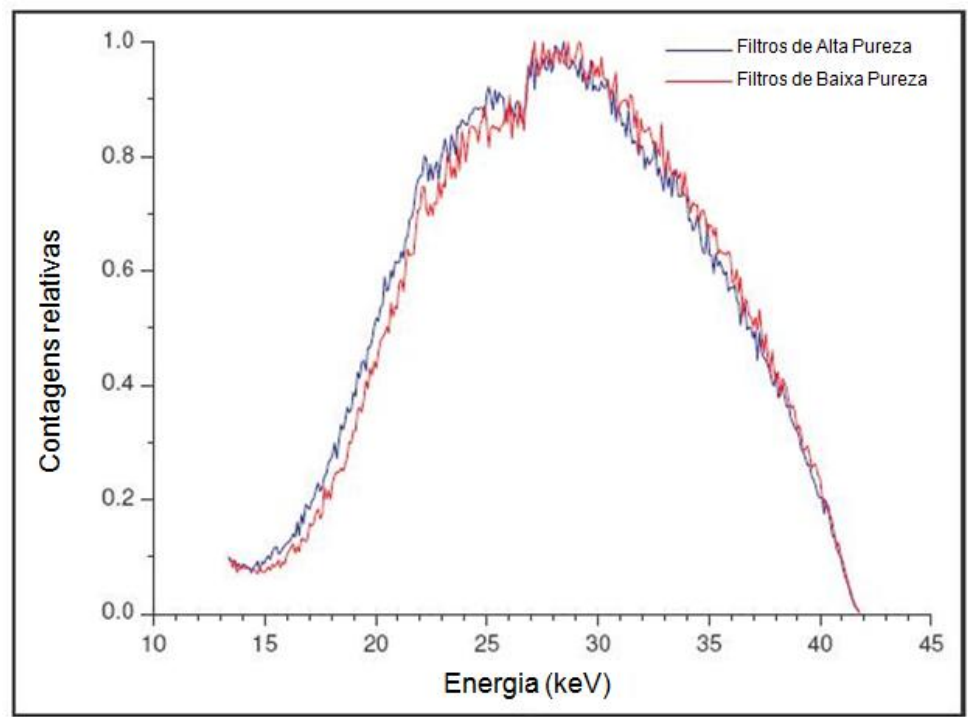

Figura 63 - Espectro de Energia da radiação de referência IEC RQR2 com filtros de alta e baixa pureza.

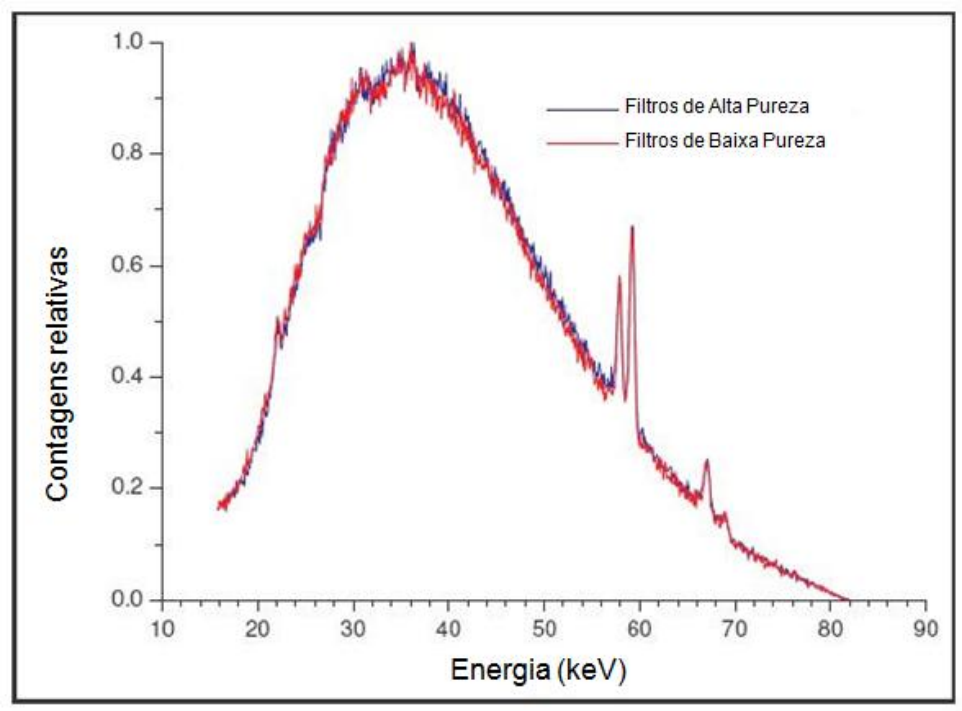

Figura 64 - Espectro de Energia da radiação de referência IEC RQR6 com filtros de alta e baixa pureza. 


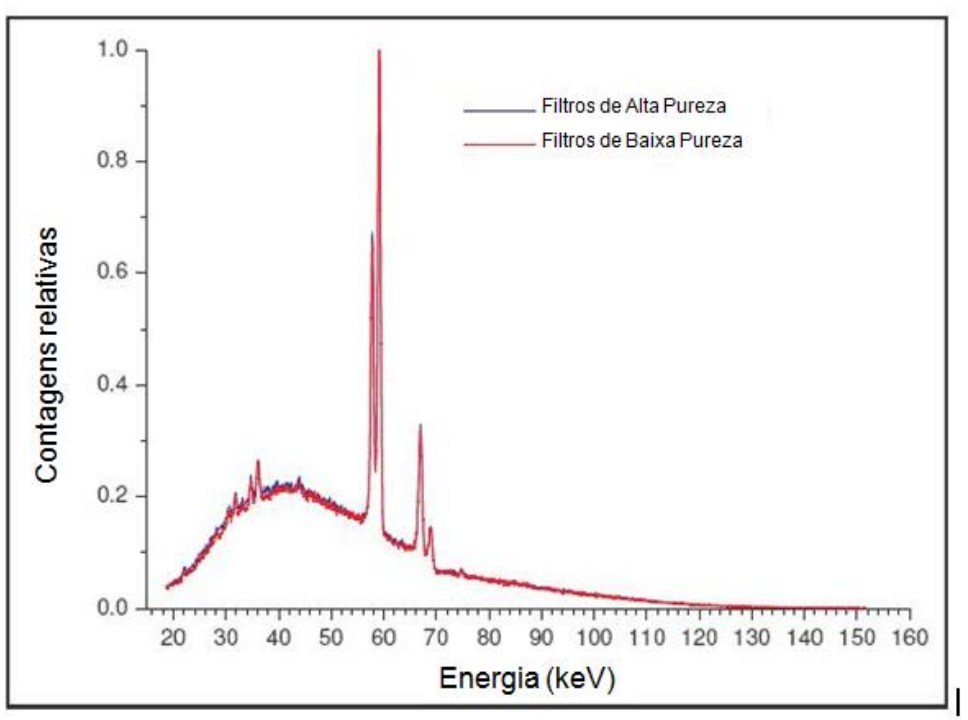

Figura 65 - Espectro de Energia da radiação de referência IEC RQR10 com filtros de alta e baixa pureza.

\subsection{Validação do dispositivo trocador de filtros com relação à radiação espalhada}

O dispositivo trocador de filtros foi verificado com relação a influência do material que compõe o drive de CD e o suporte do trocador de filtros (madeira) para determinar a influência da radiação espalhada. A validação da influência do dispositivo trocador de filtros, no feixe de radiação, foi realizada levando em consideração 4 (quatro) condições de ensaio, Figura 66, sendo estas:

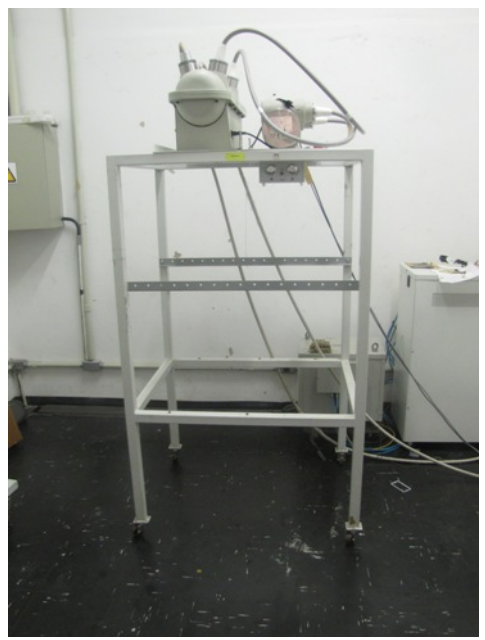

A - Sem dispositivo

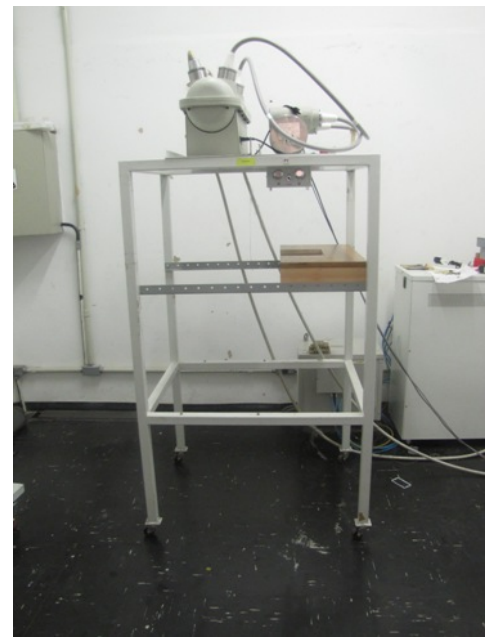

B - Sem dispositivo com suporte

Figura 66 - Condições de ensaio 


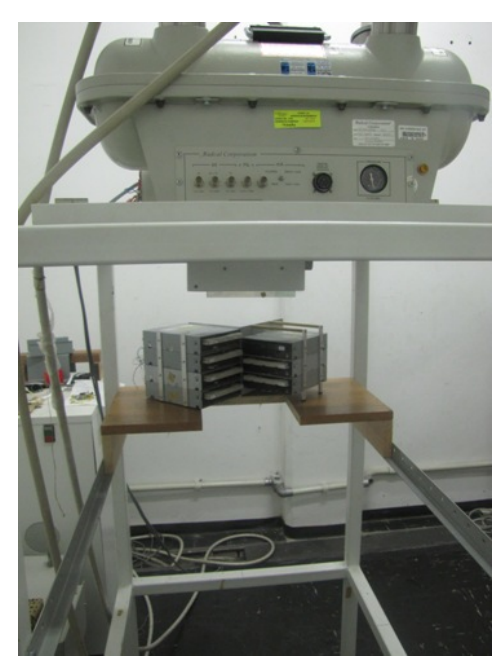

C - Com dispositivo

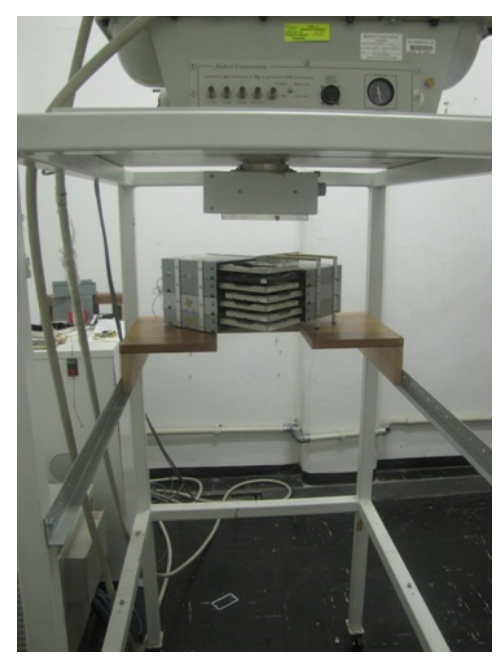

D - Com dispositivo, gavetas abertas e com suporte

Figura 66 - Condições de ensaio

Os resultados da validação são apresentados na Tabela 24. A Figura 67 mostra a comparação entre os valores de kerma no ar para as diferentes condições de ensaio para verificação da influência do material que compõe o drive e o suporte do trocador de filtros (madeira) com relação à radiação espalhada.

Tabela 24 - Verificação da influência do material que compõe o drive e o suporte do trocador de filtros (madeira) com relação à radiação espalhada

\begin{tabular}{|c|c|c|c|c|c|c|c|c|}
\hline \multirow{2}{*}{ Condição Número da Medida } & \multirow{2}{*}{ Kerma no ar (mGy) } & \multirow{2}{*}{ U95* } & \multirow{2}{*}{ Erro normalizado } \\
\cline { 2 - 8 } & $\mathbf{1}$ & $\mathbf{2}$ & $\mathbf{3}$ & $\mathbf{4}$ & $\mathbf{5}$ & & & \\
\hline 1 & 3,974 & 3,980 & 3,987 & 4,000 & 3,980 & 3,984 & 0,159 & $\mathbf{1}$ \\
\hline 2 & 3,953 & 3,962 & 4,030 & 3,982 & 3,980 & 3,981 & 0,159 & $\mathbf{0 , 0 1 2}$ \\
\hline 3 & 3,933 & 3,940 & 3,943 & 3,946 & 3,952 & 3,943 & 0,158 & $\mathbf{0 , 1 8 5}$ \\
\hline 4 & 3,962 & 3,940 & 3,948 & 3,951 & 3,951 & 3,950 & 0,158 & $\mathbf{0 , 1 5 1}$ \\
\hline
\end{tabular}

*U95 representa uma incerteza de medição calculada com nível de confiança de 95\%

\section{Média dos Valores (mGy)}

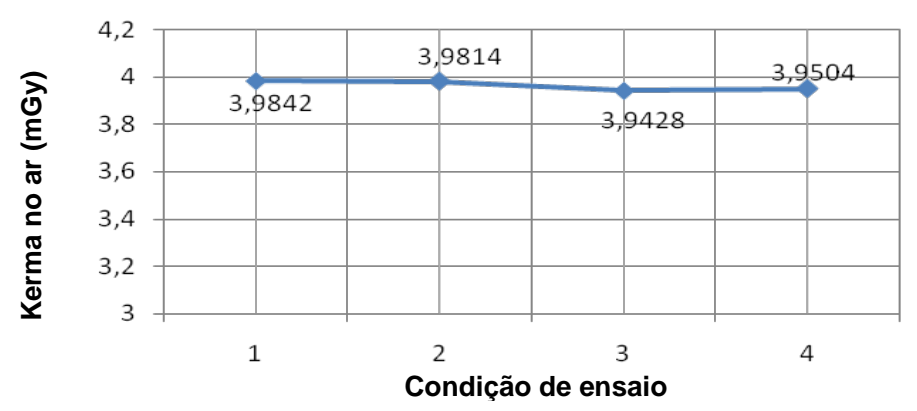

Figura 67 - Comparação entre os valores de kerma no ar para as condições de ensaio $A, B, C$ e $D$ 


\subsubsection{Análise dos resultados}

Com o resultado do cálculo do erro normalizado é constatado que a influência do dispositivo no feixe de raios $X$, sem a instalação dos filtros, é pequena.

\subsection{Validação do dispositivo de ensaio para a determinação da CSR - Cláusula 29.201.9 ABNT NBR IEC 60601-1-3: 2001}

\subsubsection{Verificação da Influência no posicionamento dos filtros na determinação da CSR}

Para a verificação da influência da posição dos filtros, no dispositivo trocador de filtros, na determinação da CSR, os filtros foram dispostos no dispositivo da maior para a menor espessura, Figura 69, e da menor para a maior espessura, sendo que ambas as situações foram comparadas com o método tradicional realizado com os filtros agrupados na primeira gaveta dos drives. A CSR determinada no método tradicional pelo agrupamento de filtros, Tabela 25, é utilizada no cálculo do erro normalizado, que consiste na comparação entre o método tradicional e as condições de distribuição dos filtros, de alta e baixa pureza, no dispositivo. Tais combinações estão demonstradas nas tabelas 21, Tabela 24 e Tabela 25. 


\section{Filtros agrupados}

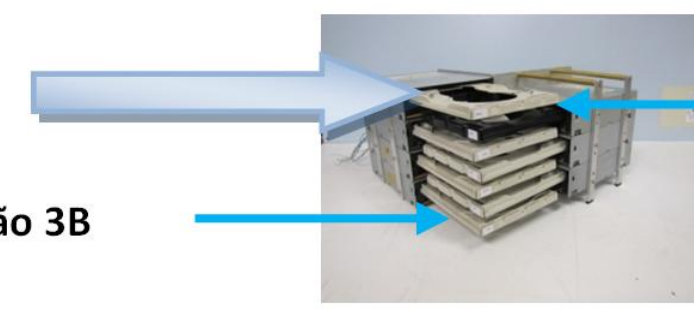

\section{Posição OB}

\section{Posição 3B}

Figura 68 - Posição dos filtros agrupados, método tradicional

Tabela 25 - CONDIÇÃO A - Filtros agrupados no primeiro drive, método tradicional.

\begin{tabular}{|c|c|c|c|c|c|c|c|c|c|c|c|}
\hline \multicolumn{12}{|c|}{ FILTROS DE BAIXA PUREZA } \\
\hline \multirow[b]{2}{*}{$\begin{array}{l}\text { Código } \\
\text { gaveta }\end{array}$} & \multirow[b]{2}{*}{ Código filtros utilizados } & \multirow[b]{2}{*}{ Espessura total (mm) } & \multicolumn{9}{|c|}{ Medidas (mGy) } \\
\hline & & & 1 & 2 & 3 & 4 & 5 & Média & Média/2 & CSR & $\begin{array}{l}\text { U95 } \\
\text { (CSR) }\end{array}$ \\
\hline-- & $\mathrm{CO}$ & 0 & 3,933 & 3,940 & 3,943 & 3,946 & 3,952 & 3,943 & \multirow{3}{*}{1,971} & \multirow{3}{*}{1,359} & \multirow{3}{*}{0,018} \\
\hline OB & $\mathrm{C} 5 \mathrm{C} 4 \mathrm{C} 3 \mathrm{C} 7$ & 1,3 & 2,030 & 2,030 & 2,033 & 2,027 & 2,034 & 2,031 & & & \\
\hline OB & C5C4C3C7C1 & 1,4 & 1,945 & 1,920 & 1,953 & 1,951 & 1,953 & 1,944 & & & \\
\hline \multicolumn{12}{|c|}{ FILTROS DE ALTA PUREZA } \\
\hline \multirow{2}{*}{$\begin{array}{l}\text { Código } \\
\text { gaveta }\end{array}$} & \multirow[b]{2}{*}{ Código filtros utilizados } & \multirow[b]{2}{*}{ Espessura total $(\mathrm{mm})$} & \multicolumn{9}{|c|}{ Medidas (mGy) } \\
\hline & & & 1 & 2 & 3 & 4 & 5 & Média & Média/2 & CSR & $\begin{array}{l}\text { U95 } \\
\text { (CSR) }\end{array}$ \\
\hline-- & $\mathrm{CO}$ & 0 & 3,941 & 3,96 & 3,959 & 3,960 & 3,962 & 3,956 & \multirow{3}{*}{1,979} & \multirow{3}{*}{1,361} & \multirow{3}{*}{0,016} \\
\hline OB & $\mathrm{C} 6 \mathrm{C} 1 \mathrm{C} 2 \mathrm{C} 3 \mathrm{C} 4$ & 1,4 & 1,981 & 1,984 & 1,985 & 1,988 & 1,989 & 1,985 & & & \\
\hline OB & C6C8 & 1,5 & 1,885 & 1,889 & 1,905 & 1,898 & 1,892 & 1,894 & & & \\
\hline
\end{tabular}




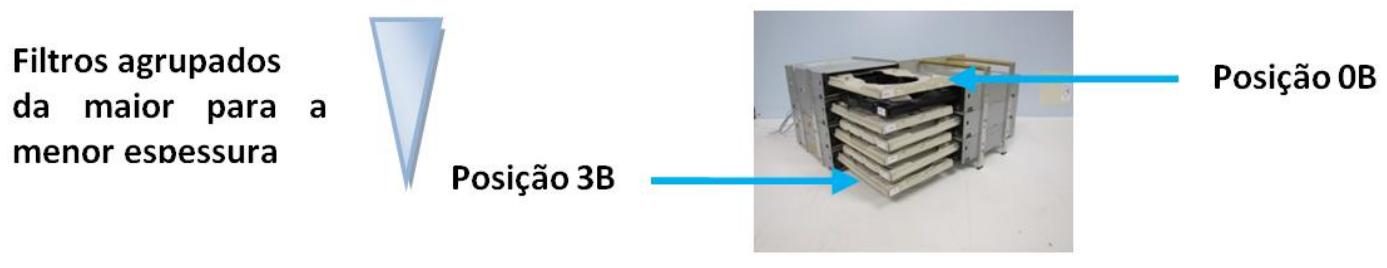

Figura 69 - Posição dos filtros agrupados da maior para a menor espessura

Tabela 26 - CONDIÇÃO B - Filtros de alta e baixa pureza dispostos da maior para a menor espessura

\begin{tabular}{|c|c|c|c|c|c|c|c|c|c|c|c|c|c|}
\hline \multicolumn{14}{|c|}{ FILTROS DE BAIXA PUREZA } \\
\hline $\begin{array}{l}\text { Código } \\
\text { Filtro }\end{array}$ & $\begin{array}{l}\text { Código } \\
\text { gaveta }\end{array}$ & Código filtros utilizados & Espessura total $(\mathrm{mm})$ & Medida 1 & Medida 2 & Medida 3 & Medida 4 & Medida 5 & Média & Média/2 & CSR & $\begin{array}{l}\text { U95 } \\
\text { (CSR) }\end{array}$ & $\begin{array}{c}\text { Erro } \\
\text { Normalizado }\end{array}$ \\
\hline $\mathrm{CO}$ & -- & $\mathrm{CO}$ & 0 & 3,933 & 3,94 & 3,943 & 3,946 & 3,952 & 3,9428 & \multirow{13}{*}{1,980} & \multirow{13}{*}{1,390} & \multirow{13}{*}{0,030} & \multirow{13}{*}{0,740} \\
\hline $\mathrm{C7}$ & $1 \mathrm{~A}$ & \multirow{6}{*}{$\mathrm{C} 5 \mathrm{C} 4 \mathrm{C} 3 \mathrm{C} 7$} & \multirow{6}{*}{1,3} & \multirow{6}{*}{2,021} & \multirow{6}{*}{2,024} & \multirow{6}{*}{2,031} & \multirow{6}{*}{2,032} & \multirow{6}{*}{2,032} & \multirow{6}{*}{2,028} & & & & \\
\hline C3 & $2 \mathrm{~A}$ & & & & & & & & & & & & \\
\hline C5 & $3 \mathrm{~A}$ & & & & & & & & & & & & \\
\hline $\mathrm{C} 10$ & $\mathrm{OB}$ & & & & & & & & & & & & \\
\hline $\mathrm{C} 4$ & 1B & & & & & & & & & & & & \\
\hline $\mathrm{C} 1$ & $2 \mathrm{~B}$ & & & & & & & & & & & & \\
\hline $\mathrm{C} 7$ & $1 \mathrm{~A}$ & \multirow{6}{*}{$\mathrm{C} 5 \mathrm{C} 4 \mathrm{C} 3 \mathrm{C} 7 \mathrm{C} 1$} & \multirow{6}{*}{1,4} & \multirow{6}{*}{1,958} & \multirow{6}{*}{1,963} & \multirow{6}{*}{1,965} & \multirow{6}{*}{1,967} & \multirow{6}{*}{1,976} & \multirow{6}{*}{1,966} & & & & \\
\hline C3 & $2 \mathrm{~A}$ & & & & & & & & & & & & \\
\hline $\mathrm{C} 5$ & $3 \mathrm{~A}$ & & & & & & & & & & & & \\
\hline C10 & $\mathrm{OB}$ & & & & & & & & & & & & \\
\hline $\mathrm{C} 4$ & 1B & & & & & & & & & & & & \\
\hline C1 & $2 \mathrm{~B}$ & & & & & & & & & & & & \\
\hline & & & & FILTRO & S DE ALTA & PUREZA & & & & & & & \\
\hline $\begin{array}{c}\text { Código } \\
\text { Filtro }\end{array}$ & $\begin{array}{l}\text { Código } \\
\text { gaveta }\end{array}$ & Código filtros utilizados & Espessura total (mm) & Medida 1 & Medida 2 & Medida 3 & Medida 4 & Medida 5 & Média & Média/2 & CSR & $\begin{array}{l}\text { U95 } \\
\text { (CSR) }\end{array}$ & $\begin{array}{c}\text { Erro } \\
\text { Normalizado }\end{array}$ \\
\hline $\mathrm{CO}$ & -- & $\mathrm{CO}$ & 0 & 3,941 & 3,96 & 3,959 & 3,96 & 3,962 & 3,9564 & & & & \\
\hline C6 & $1 \mathrm{~A}$ & \multirow{6}{*}{$\mathrm{C} 6 \mathrm{C} 1 \mathrm{C} 2 \mathrm{C} 3 \mathrm{C} 4$} & \multirow{6}{*}{1,4} & \multirow{6}{*}{1,973} & \multirow{6}{*}{1,979} & \multirow{6}{*}{1,980} & \multirow{6}{*}{1,984} & & & & & & \\
\hline C4 & $2 \mathrm{~A}$ & & & & & & & & & & & & \\
\hline $\mathrm{C} 2$ & $3 \mathrm{~A}$ & & & & & & & 1983 & 1980 & & & & \\
\hline $\mathrm{C} 8$ & $\mathrm{OB}$ & & & & & & & $1,1,00$ & 1,300 & & & & \\
\hline $\mathrm{C} 3$ & $1 \mathrm{~B}$ & & & & & & & & & & & & \\
\hline C1 & $2 \mathrm{~B}$ & & & & & & & & & 1,980 & 1,360 & 0,020 & 0,260 \\
\hline C6 & $1 \mathrm{~A}$ & & & & & & & & & & & & \\
\hline $\mathrm{C} 4$ & $2 \mathrm{~A}$ & & & & & & & & & & & & \\
\hline $\mathrm{C} 2$ & $3 \mathrm{~A}$ & $\mathrm{C} 6 \mathrm{C} 8$ & 15 & 1882 & 1883 & 1885 & 1889 & 1888 & 1885 & & & & \\
\hline $\mathrm{C} 8$ & $\mathrm{OB}$ & 6008 & $\perp, 0$ & & & & & 1,000 & & & & & \\
\hline $\mathrm{C} 3$ & $1 \mathrm{~B}$ & & & & & & & & & & & & \\
\hline $\mathrm{C} 1$ & $2 \mathrm{~B}$ & & & & & & & & & & & & \\
\hline
\end{tabular}


Filtros agrupados

da menor para a

maior espessura

Posição 3B

Posição 0B

Figura 70 - Posição dos filtros agrupados da menor para a maior espessura

Tabela 27 - CONDIÇÃO C - Filtros de baixa e de alta pureza dispostos da menor para a maior espessura

\begin{tabular}{|c|c|c|c|c|c|c|c|c|c|c|c|c|c|}
\hline \multicolumn{14}{|c|}{ FILTROS DE BAIXA PUREZA } \\
\hline $\begin{array}{l}\text { Código } \\
\text { Filtro }\end{array}$ & $\begin{array}{l}\text { Código } \\
\text { gaveta }\end{array}$ & Código filtros utilizados & Espessura total $(\mathrm{mm})$ & Medida 1 & Medida 2 & Medida 3 & Medida 4 & Medida 5 & Média & Média/2 & CSR & $\begin{array}{l}\text { U95 } \\
\text { (CSR) }\end{array}$ & $\begin{array}{c}\text { Erro } \\
\text { Normalizado }\end{array}$ \\
\hline $\mathrm{CO}$ & -- & $\mathrm{CO}$ & 0 & 3,933 & 3,94 & 3,943 & 3,946 & 3,952 & 3,9428 & \multirow{13}{*}{1,980} & \multirow{13}{*}{1,370} & \multirow{13}{*}{0,020} & \multirow{13}{*}{0,350} \\
\hline C1 & $1 \mathrm{~A}$ & \multirow{6}{*}{$\mathrm{C} 5 \mathrm{C} 4 \mathrm{C} 3 \mathrm{C} 7$} & \multirow{6}{*}{1,3} & \multirow{6}{*}{2,023} & \multirow{6}{*}{2,03} & \multirow{6}{*}{2,03} & \multirow{6}{*}{2,037} & \multirow{6}{*}{2,035} & \multirow{6}{*}{2,031} & & & & \\
\hline $\mathrm{C} 4$ & $2 \mathrm{~A}$ & & & & & & & & & & & & \\
\hline $\mathrm{C} 10$ & $3 A$ & & & & & & & & & & & & \\
\hline $\mathrm{C} 5$ & $\mathrm{OB}$ & & & & & & & & & & & & \\
\hline C3 & $1 \mathrm{~B}$ & & & & & & & & & & & & \\
\hline C7 & $2 \mathrm{~B}$ & & & & & & & & & & & & \\
\hline C1 & $1 \mathrm{~A}$ & \multirow{6}{*}{$\mathrm{C} 5 \mathrm{C} 4 \mathrm{C} 3 \mathrm{C} 7 \mathrm{C} 1$} & \multirow{6}{*}{1,4} & \multirow{6}{*}{1,951} & \multirow{6}{*}{1,953} & \multirow{6}{*}{1,958} & \multirow{6}{*}{1,954} & \multirow{6}{*}{1,956} & \multirow{6}{*}{1,9544} & & & & \\
\hline C4 & $2 \mathrm{~A}$ & & & & & & & & & & & & \\
\hline $\mathrm{C} 10$ & $3 \mathrm{~A}$ & & & & & & & & & & & & \\
\hline $\mathrm{C} 5$ & $\mathrm{OB}$ & & & & & & & & & & & & \\
\hline $\mathrm{C} 3$ & $1 \mathrm{~B}$ & & & & & & & & & & & & \\
\hline C7 & $2 \mathrm{~B}$ & & & & & & & & & & & & \\
\hline \multicolumn{14}{|c|}{ FILTROS DE ALTA PUREZA } \\
\hline $\begin{array}{l}\text { Código } \\
\text { Filtro }\end{array}$ & $\begin{array}{l}\text { Código } \\
\text { gaveta }\end{array}$ & Código filtros utilizados & Espessura total (mm) & Medida 1 & Medida 2 & Medida 3 & Medida 4 & Medida 5 & Média & Média/2 & CSR & $\begin{array}{l}\text { U95 } \\
\text { (CSR) }\end{array}$ & $\begin{array}{c}\text { Erro } \\
\text { Normalizado }\end{array}$ \\
\hline $\mathrm{CO}$ & -- & $\mathrm{CO}$ & 0 & 3,941 & 3,96 & 3,959 & \begin{tabular}{l|l}
3,96 \\
\end{tabular} & 3,962 & 3,9564 & & & & \\
\hline C1 & $1 \mathrm{~A}$ & \multirow{6}{*}{$\mathrm{C} 6 \mathrm{C} 1 \mathrm{C} 2 \mathrm{C} 3 \mathrm{C} 4$} & \multirow{6}{*}{1,4} & \multirow{6}{*}{1,975} & \multirow{6}{*}{1,977} & \multirow{6}{*}{1,979} & & & & & & & \\
\hline $\mathrm{C} 3$ & $2 \mathrm{~A}$ & & & & & & & & & & & & \\
\hline $\mathrm{C} 8$ & $3 \mathrm{~A}$ & & & & & & 1078 & 1979 & 1978 & & & & \\
\hline $\mathrm{C} 2$ & $\mathrm{OB}$ & & & & & & $1,9 / 8$ & $1,9 / 9$ & 1,918 & & & & \\
\hline C4 & $1 \mathrm{~B}$ & & & & & & & & & & & & \\
\hline $\mathrm{C} 6$ & $2 \mathrm{~B}$ & & & & & & & & & 1,98 & 1,354 & 0,012 & 0,393 \\
\hline $\mathrm{C} 1$ & $1 \mathrm{~A}$ & & & & & & & & & & & & \\
\hline $\mathrm{C} 3$ & $2 \mathrm{~A}$ & & & & & & & & & & & & \\
\hline $\mathrm{C} 8$ & $3 \mathrm{~A}$ & ceco & 15 & 1870 & 1007 & 1895 & 1891 & 1000 & 1007 & & & & \\
\hline $\mathrm{C} 2$ & OB & Coco & 1,5 & 1,819 & 1,882 & 1,885 & 1,884 & 1,880 & 1,882 & & & & \\
\hline C4 & $1 \mathrm{~B}$ & & & & & & & & & & & & \\
\hline $\mathrm{C6}$ & 2B & & & & & & & & & & & & \\
\hline
\end{tabular}




\subsubsection{Análise dos resultados}

Os valores do erro normalizado calculado nas tabelas 21 a 23, todos inferiores a 1 , mostram que tanto o posicionamento quanto a pureza dos filtros são fatores de influência na determinação da CSR, e a Tabela 28 mostra que a maior diferença encontrada entre as condições $A, B$ e $C$ foi de 0,0261 mmAl, valor considerado desprezível pois é 4 vezes menor que o menor filtro utilizado $(0,1 \mathrm{mmAl})$. Portanto, considera-se que o dispositivo trocador de filtros e os filtros de baixa pureza estão aptos para serem utilizados no dispositivo de ensaio.

Tabela 28 - Determinação da CSR com os filtros de alta pureza dispostos da menor para a maior espessura

\begin{tabular}{|l|c|c|c|}
\hline \multicolumn{1}{|c|}{ Condição } & $\begin{array}{c}\text { CSR Filtros de Baixa } \\
\text { pureza (mmAL) }\end{array}$ & $\begin{array}{c}\text { CSR Filtros de Alta } \\
\text { pureza (mmAl) }\end{array}$ & $\begin{array}{c}\text { Diferença da } \\
\text { CSR (mmAl) }\end{array}$ \\
\hline $\begin{array}{l}\text { A - As medidas foram realizadas com todos os } \\
\text { filtros na gaveta 0B }\end{array}$ & 1,359 & 1,361 & $\mathbf{0 , 0 0 3}$ \\
\hline $\begin{array}{l}\text { B - As medidas foram realizadas com os filtros } \\
\text { dispostos da maior para a menor espessura }\end{array}$ & 1,382 & 1,356 & $\mathbf{0 , 0 2 6}$ \\
\hline $\begin{array}{l}\text { C -As medidas foram realizadas com os filtros } \\
\text { dispostos da menor para a maior espessura }\end{array}$ & 1,368 & 1,354 & $\mathbf{0 , 0 1 4}$ \\
\hline
\end{tabular}

\subsection{Validação do dispositivo de ensaio de acordo com a IEC 60522: 1999}

A validação dos ensaios abaixo relacionados consistiu na verificação da filtração com equivalência de qualidade de cada material que compõe a filtração inerente do conjunto emissor de radiação $X$, sendo que tal método é o mesmo para os demais ensaios uma vez que, apenas o material avaliado é alterado, na Tabela 29 e na Figura 71 são apresentados os resultados das medições e a comparação entre o dispositivo de ensaio desenvolvido e o gerador de raios $X$ de referência. 
Tabela 29 - Comparação do método da norma IEC 60522: 1999 realizado pelo o dispositivo de ensaio pelo gerador de referencia

\begin{tabular}{|c|c|c|c|c|c|c|}
\hline \multirow{3}{*}{ MEDIÇÕES } & \multirow{3}{*}{ MATERIAL } & \multicolumn{5}{|c|}{ MÉTODO } \\
\hline & & \multicolumn{2}{|c|}{$\begin{array}{l}\text { IEC 60522: } 1999 \text { Equipamento } \\
\text { Industrial (Referência) }\end{array}$} & \multicolumn{2}{|c|}{ Setup desenvolvido } & \multirow{2}{*}{$\begin{array}{c}\text { ERRO NORMALIZADO* } \\
\text { IEC 60522: } 1999 \\
\end{array}$} \\
\hline & & Valor (mmAl) & U95* (mmAl) & Valor (mmAl) & U95* (mmAl) & \\
\hline 1 & $\mathrm{J1}$ & 0,161 & 0,021 & 0,154 & 0,027 & $-0,205$ \\
\hline 2 & $\mathrm{~J} 2$ & 0,164 & 0,021 & 0,154 & 0,040 & $-0,221$ \\
\hline 3 & $\mathrm{J3}$ & 0,104 & 0,018 & 0,149 & 0,029 & 1,318 \\
\hline 4 & $\mathrm{J4}$ & 0,106 & 0,018 & 0,104 & 0,016 & $-0,083$ \\
\hline 5 & $\mathrm{~J} 5$ & 0,107 & 0,012 & 0,106 & 0,027 & $-0,034$ \\
\hline 6 & $\mathrm{~J} 6$ & 0,105 & 0,024 & 0,104 & 0,030 & $-0,026$ \\
\hline 7 & $\mathrm{J7}$ & 0,106 & 0,018 & 0,106 & 0,015 & 0,000 \\
\hline 8 & V1 & 0,918 & 0,018 & 0,918 & 0,040 & 0,000 \\
\hline 9 & V2 & 0,918 & 0,018 & 0,918 & 0,040 & 0,000 \\
\hline 10 & V3 & 1,077 & 0,020 & 1,053 & 0,018 & $-0,892$ \\
\hline 11 & V4 & 0,812 & 0,018 & 0,814 & 0,019 & 0,076 \\
\hline 12 & V5 & 1,074 & 0,022 & 1,079 & 0,027 & 0,144 \\
\hline 13 & V6 & 1,174 & 0,020 & 1,147 & 0,023 & $-0,886$ \\
\hline 14 & V7 & 0,817 & 0,017 & 0,817 & 0,014 & 0,000 \\
\hline 15 & J1+OLEO & 0,161 & 0,021 & 0,154 & 0,027 & $-0,205$ \\
\hline 16 & J2+OLEO & 0,164 & 0,021 & 0,154 & 0,040 & $-0,221$ \\
\hline 17 & J3+OLEO & 0,104 & 0,019 & 0,149 & 0,029 & 1,298 \\
\hline 18 & J4+OLEO & 0,106 & 0,019 & 0,104 & 0,017 & $-0,078$ \\
\hline 19 & J5+OLEO & 0,107 & 0,012 & 0,104 & 0,019 & $-0,133$ \\
\hline 20 & J6+OLEO & 0,105 & 0,021 & 0,105 & 0,021 & 0,000 \\
\hline 21 & J7+OLEO & 0,106 & 0,018 & 0,106 & 0,015 & 0,000 \\
\hline \multicolumn{5}{|c|}{ Legenda - Materiais } & \multirow{4}{*}{\multicolumn{2}{|c|}{$\begin{array}{l}\text { *Utilizando o equipamento Industrial } \\
\text { como referência }\end{array}$}} \\
\hline \multicolumn{5}{|c|}{ J1 a J7 - Janelas fabricantes 1 a 7} & & \\
\hline \multicolumn{5}{|c|}{ V1 a V7 - Vidro do tubo de raios X fabricantes 1 a 7} & & \\
\hline \multicolumn{5}{|c|}{ J1+OLEO - Janelas+ Óleo - fabricantes 1 a 7} & & \\
\hline
\end{tabular}

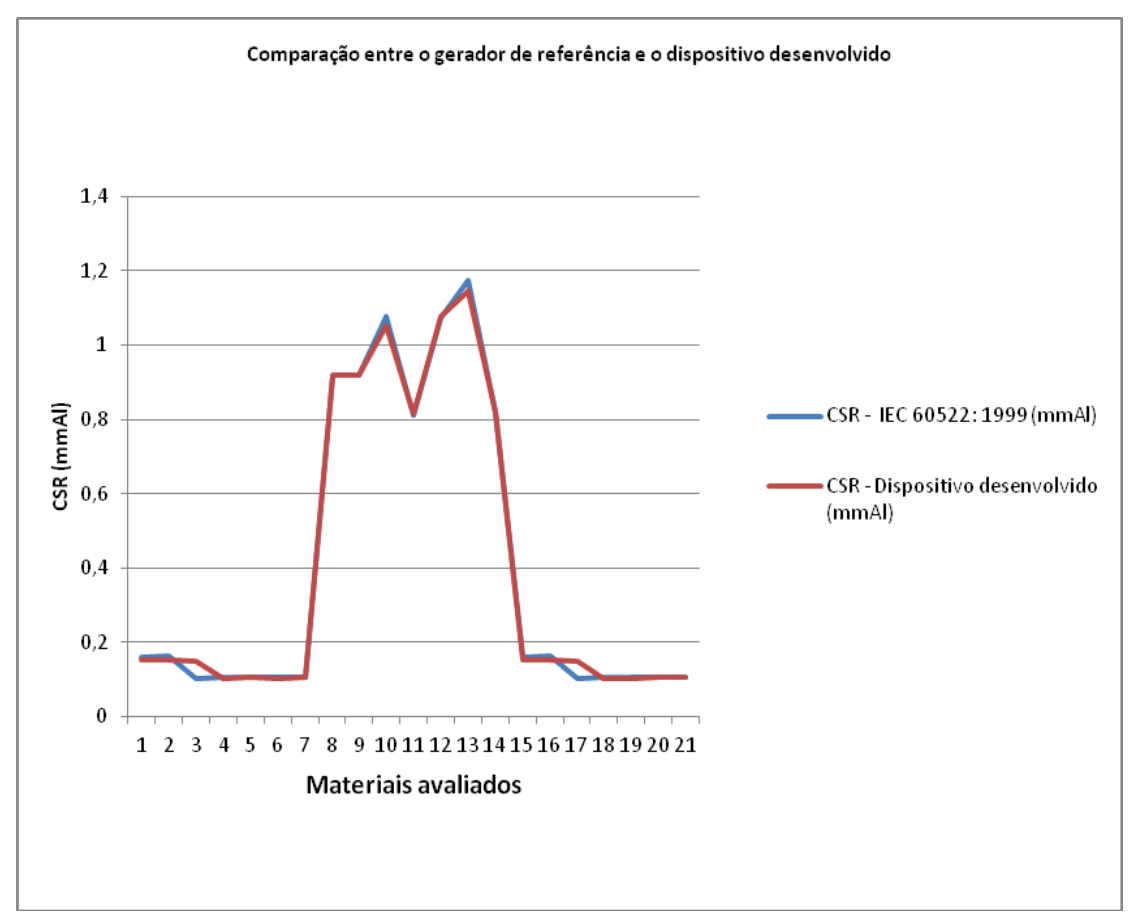

Figura 71 - Valores de CSR obtidos com o gerador de referência e o com o dispositivo desenvolvido 


\subsubsection{Análise dos resultados}

O dispositivo de ensaio desenvolvido, comparado ao equipamento de referência (Equipamento industrial), apresentou erro normalizado compatível na maioria dos materiais ensaiados, onde as medições 3 e 17 apresentaram valores entre 1 e 2. De acordo com o critério do erro normalizado, são valores questionáveis que podem ser aceitos, mas indicam possíveis problemas de reprodutibilidade o que justifica e reforça a necessidade da automação proposta neste trabalho.

A diferença entre os valores das medições 1 e 2, realizadas pelo dispositivo desenvolvido e pelo sistema de referência, pode ser justificada pela diferença da filtração inerente entre os arranjos de ensaios o que possivelmente implicou em pequenas variações espectrais entre ambos.

\subsection{Parâmetros elétricos}

Durante todas as medições realizadas, para a validação do dispositivo de ensaio, as grandezas associadas à geração da radiação $X$ foram verificadas e registradas. Foram realizadas um total de 361 medições que estão representadas nos figuras 12, 13, 14 e 15, de Tensão, Tempo, Corrente e Produto Corrente tempo respectivamente.

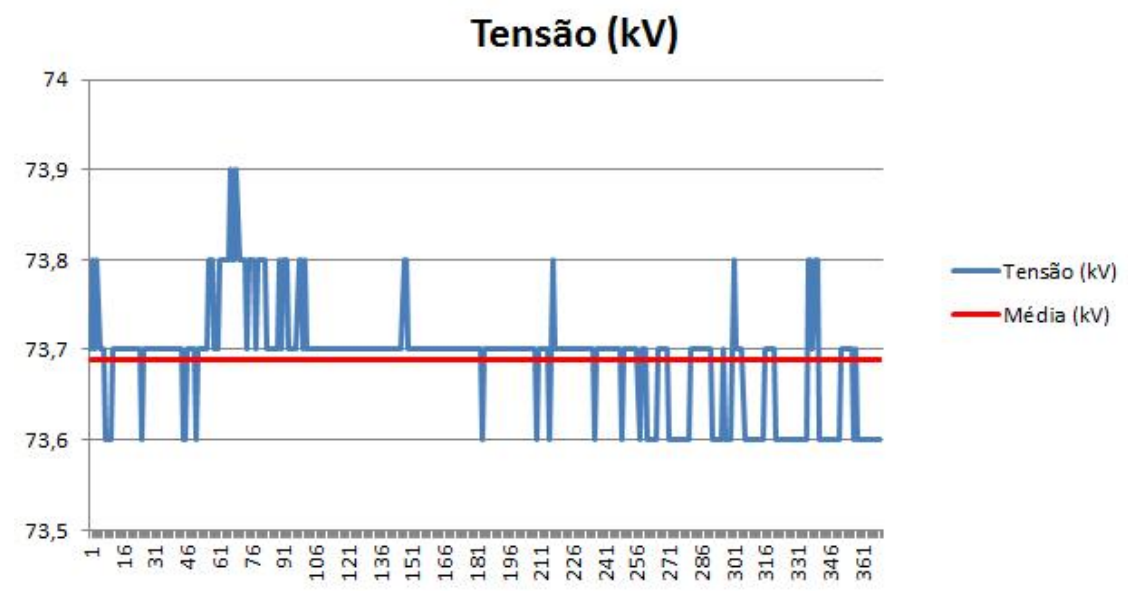

Figura 72 - Variação da tensão (kV) durante o período de testes. 
Tempo (ms)

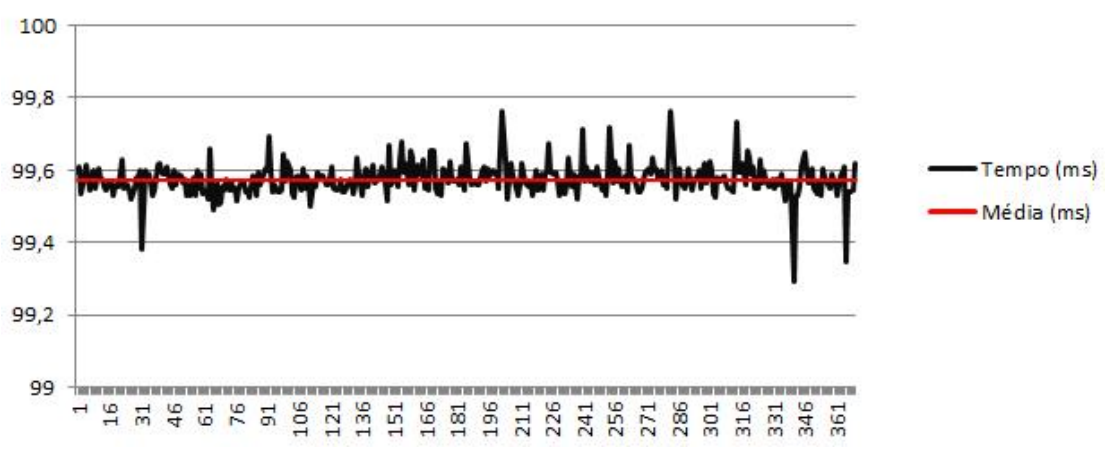

Figura 73 - Valores de tempo (ms) medidos durante o período de testes.

\section{Corrente (mA)}

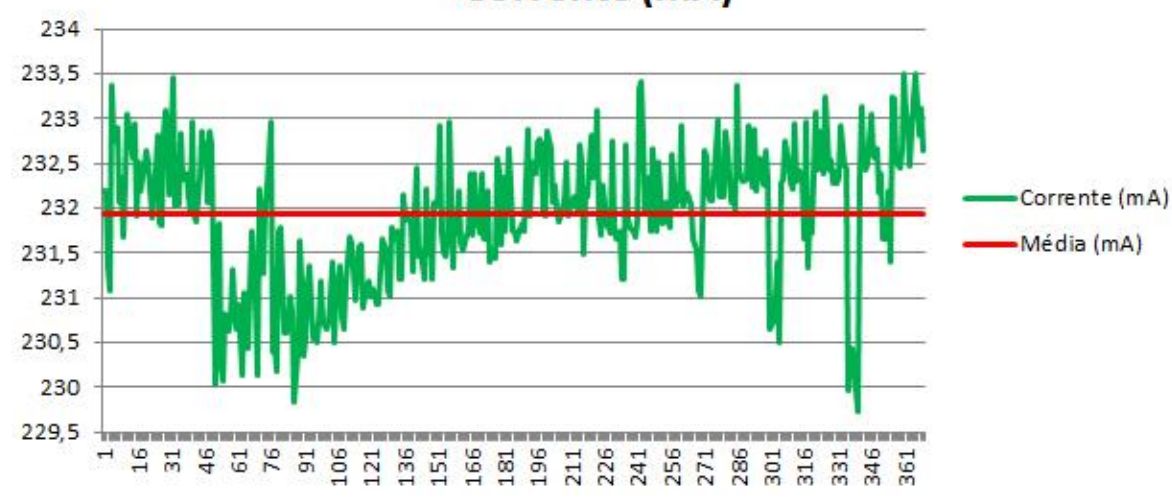

Figura 74 - Variação da corrente (mA) durante o período de testes

Produto Corrente x Tempo (mAs)

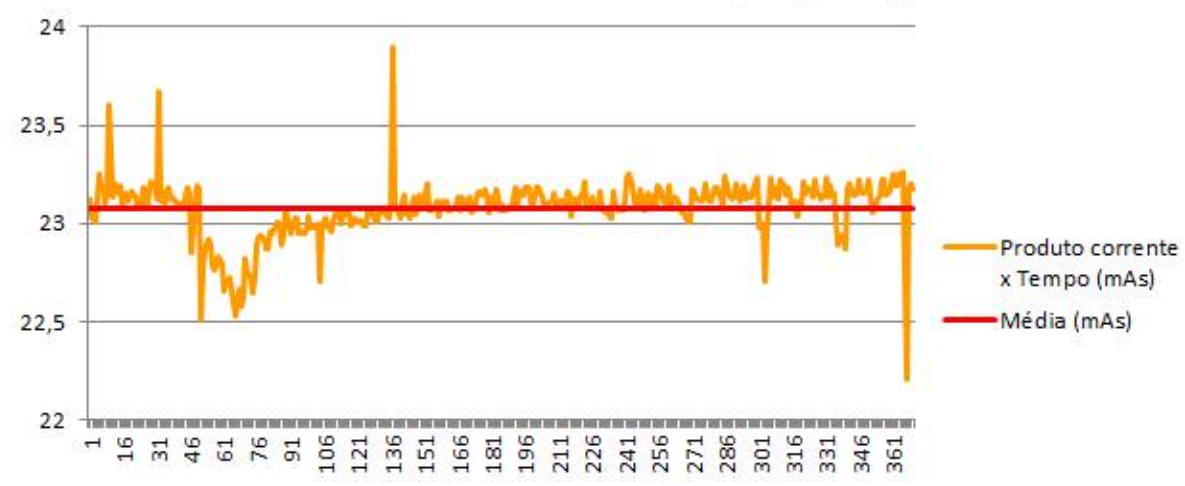

Figura 75 - Produto corrente - tempo (mAs)

Os resultados mostram que o gerador de raios $X$, que faz parte do dispositivo de ensaio desenvolvido, apresentou um comportamento estável demonstrando total aptidão para a realização dos ensaios. Na Tabela 30 estão relacionados os valores de exatidão obtidos as grandezas medidas pelo conjunto formado pelo Divisor de Alta-tensão /Osciloscópio. 
Tabela 30. Valores de exatidão das grandezas obtidas pelo conjunto formado pelo Divisor de Alta-tensão /Osciloscópio

\begin{tabular}{|l|c|}
\hline \multicolumn{1}{|c|}{ Grandezas } & Exatidão \\
\hline Alta-Tensão & $1,5 \%$ \\
\hline Corrente (A) & $2,0 \%$ \\
\hline Tempo (s) & $1 \mathrm{ppm}$ \\
\hline
\end{tabular}




\section{Conclusões}

Os resultados foram satisfatórios e mostraram que o dispositivo de ensaio desenvolvido atendeu as expectativas bem como aos critérios estabelecidos para a sua construção onde foi constatado que:

O dispositivo de ensaio atende as exigências dos requisitos da ABNT NBR IEC 60601-1-3: e da norma IEC 60522: 1999, pois os ensaios, que consistem essencialmente na caracterização da filtração com equivalência de qualidade dos materiais que interceptam o feixe de radiação das cláusulas 29.201.3, 29.201.4 e 29.201.5, 29.201.6 foram realizados de acordo com as especificações para a realização dos ensaios.

Para atender os requisitos da acreditação da STEEE junto ao INMETRO, o dispositivo foi desenvolvido de acordo com os requisitos da ABNT NBR ISO IEC 17025: 2005, para tanto o mesmo foi validado de acordo com os requisitos aplicáveis da norma citada, o que pode ser concluído que o mesmo está em conformidade com os requisitos ABNT NBR ISO IEC 17025: 2005.

Com relação a segurança, otimização e incerteza de medição, a revisão do procedimento de ensaio do laboratório incorporando o dispositivo de ensaio desenvolvido, demonstrou que a interação do operador com a sala radiológica bem como com os ajustes e preparação dos ensaios foram reduzidas melhorando a questão da segurança e das variáveis das incertezas de medição relacionadas a operação manual de ajustes e de instrumentos.

A automação da troca dos filtros, além de contribuir para a questão da segurança reduziu o tempo de execução dos ensaios, pois não há mais a necessidade do operador trocar manualmente os filtros de alumínio envolvidos nos ensaios para a determinação da CSR e da filtração com equivalência de qualidade em alumínio.

A questão ambiental foi respeitada através da utilização dos drives de CD fora de uso para a leitura, mas funcional nos aspectos mecânicos. Tais drives se mostraram totalmente eficazes dentro da proposta deste trabalho, visto que os mesmos atenderam as validações as quais foram submetidos. 
A utilização dos drives de CD e do sistema de aquisição de dados da STEEE, permitiram também a redução dos custos de desenvolvimento, pois a proposta inicial era a utilização de um conjunto de rodas de filtros para realizar a combinação dos mesmos, sendo que para a construção de tal sistema seria necessária a aquisição de placas de alumínio para a confecção das rodas, seria necessário também a construção de um sistema de suporte com motores para realizar o movimento de rotação para seleção do filtro de interesse e além disso o desenvolvimento do sistema de controle.

Para a continuidade do trabalho a proposta, em um possível doutorado, é o aprimoramento do dispositivo de ensaio por meio do desenvolvimento de um sistema integrado de aquisição e de seleção de amostra a ser ensaiada. 


\section{APÊNDICE 1 ABNT NBR IEC 60601-1-3: 2001}

\section{RADIAÇÃO X}

Nota: De 29.201 a 29.208 relacionanciam-se somente a EQUIPAMENTO DE RAIOS X para diagnóstico médico.

\subsection{QUALIDADE DE RADIAÇÃO}

Nota - De 29.201.1 a 29.201.9 relacionam-se com a necessidade da QUALIDADE DE RADIAÇÃO do FEIXE DE RADIAÇÃO a ser apropriada para produzir as imagens com fins diagnósticos sem que seja necessário efetuar EXPOSIÇÕES que resultam em altas DOSES ABSORVIDAS ao PACIENTE. As medidas prescritas referem-se à QUALIDADE DE RADIAÇÃO em termos tanto de FILTRAÇÃO como o valor da PRIMEIRA CAMADA SEMIRREDUTORA, para atender a compatibilidade com a regulamentação nacional estabelecida.

Nos EQUIPAMENTOS DE RAIOS X para aplicações odontológicas, restrições são estabelecidas quanto à faixa de tensão operacional para UTILIZAÇÃO NORMAL.

\subsubsection{Camadas semirredutoras em EQUIPAMENTO DE RAIOS X}

No EQUIPAMENTO DE RAIOS X, para todas as configurações em UTILIZAÇÃO NORMAL, a primeira CAMADA SEMIRREDUTORA em relação ao FEIXE DE RAIOS $X$ incidente no PACIENTE, não deve ser menor que o mínimo permissível para os valores dados na Tabela 204.

A conformidade é verificada pelo ensaio descrito em 29.201.9

\subsubsection{FILTRAÇÃO no CONJUNTO-EMISSOR DE RADIAÇÃO X}

Em relação à FILTRAÇÃO, o CONJUNTO-EMISSOR DE RADIAÇÃO $X$ deve atender às seguintes prescrições:

- nos CONJUNTOS-EMISSORES DE RADIAÇÃO X, outros que não aqueles especificados exclusivamente para mamografia com TENSÃO DO TUBO DE RAIOS X NOMINAL não excedendo $50 \mathrm{kV}$, a FILTRAÇÃO COM EQUIVALÊNCIA DE QUALIDADE que surge dos materiais que interceptam a passagem do FEIXE DE RADIAÇÃO $X$, deve ser conforme segue:

a) não menos que $0,5 \mathrm{~mm}$ Al dos materiais que são irremovíveis em UTILIZAÇÃO NORMAL;

b) um valor de FILTROS ADICIONAIS fixos, tal que a soma deste valor com a quantidade decorrente dos materiais irremovíveis (ver a) acima) não seja inferior a 1,5 mm Al;

- os FILTROS ADICIONAIS fixos não devem ser removíveis sem a utilização de FERRAMENTAS;

- os DOCUMENTOS ACOMPANHANTES devem incluir, nas INSTRUÇÕES DE MONTAGEM dadas para uma aplicação em particular, INSTRUÇÕES relativas à FILTRAÇÃO TOTAL prescritas para atender 29.201.5 a respeito de elementos do EQUIPAMENTO DE RAIOS X em questão.

A conformidade é verificada por inspeção, pelo exame dos DOCUMENTOS ACOMPANHANTES e pela utilização dos ensaios descritos em 29.201.7 e 29.201.8, conforme apropriado. 
Tabela 204 - CAMADAS SEMIRREDUTORAS em EQUIPAMENTO DE RAIOS X

\begin{tabular}{|c|c|c|c|}
\hline Aplicação & $\begin{array}{l}\text { TENSÃO DO TUBC } \\
\text { Faixa operacional } \\
\text { para UTILIZAÇÃO } \\
\text { NORMAL } \\
\text { kV }\end{array}$ & $\begin{array}{l}\text { IOS X } \\
\text { Valor } \\
\text { selecionado } \\
\text { (ver NOTA 1) } \\
\text { kV }\end{array}$ & $\begin{array}{c}\text { Primeira CAMADA } \\
\text { SEMIRREDUTORA mínima } \\
\text { Permissível (mmAl) }\end{array}$ \\
\hline $\begin{array}{l}\text { Procedimentos especiais } \\
\text { de baixa tensão }\end{array}$ & até 50 inclusive & $\begin{array}{c}<30 \\
30 \\
40 \\
50\end{array}$ & $\begin{array}{c}\text { ver NOTA } 2 \\
0,3 \\
0,4 \\
0,5\end{array}$ \\
\hline $\begin{array}{l}\text { Utilização odontológica } \\
\text { com RECEPTOR DE } \\
\text { IMAGEM DE }\end{array}$ & $\begin{array}{l}\text { de } 50 \text { até } 70 \\
\text { inclusive }\end{array}$ & $\begin{array}{c}50 \\
60 \\
70 \\
\end{array}$ & $\begin{array}{l}1,5 \\
1,5 \\
1,5 \\
\end{array}$ \\
\hline RADIAÇÃO X intra-oral & $\begin{array}{l}\text { de } 50 \text { até } 90 \\
\text { inclusive }\end{array}$ & $\begin{array}{l}50 \\
60 \\
70 \\
80 \\
90\end{array}$ & $\begin{array}{l}1,5 \\
1,8 \\
2,1 \\
2,3 \\
2,5\end{array}$ \\
\hline $\begin{array}{l}\text { Outras aplicações } \\
\text { Odontológicas }\end{array}$ & $\begin{array}{l}\text { de } 50 \text { até } 70 \\
\text { inclusive }\end{array}$ & $\begin{array}{l}50 \\
60 \\
70\end{array}$ & $\begin{array}{l}1,2 \\
1,3 \\
1,5\end{array}$ \\
\hline & $\begin{array}{l}\text { de } 50 \text { até } 125 \\
\text { inclusive }\end{array}$ & $\begin{array}{r}50 \\
60 \\
70 \\
80 \\
90 \\
100 \\
110 \\
120 \\
125\end{array}$ & $\begin{array}{l}1,5 \\
1,8 \\
2,1 \\
2,3 \\
2,5 \\
2,7 \\
3,0 \\
3,2 \\
3,3\end{array}$ \\
\hline Outras aplicações & de 30 para cima & $\begin{array}{r}<50 \\
50 \\
60 \\
70 \\
80 \\
90 \\
100 \\
110 \\
120 \\
130 \\
140 \\
150 \\
>150\end{array}$ & $\begin{array}{c}\text { Ver Nota } 2 \\
1,5 \\
1,8 \\
2,1 \\
2,3 \\
2,5 \\
2,7 \\
3,0 \\
3,2 \\
3,5 \\
3,8 \\
4,1 \\
\text { Ver Nota } 2\end{array}$ \\
\hline \multicolumn{4}{|c|}{$\begin{array}{l}\text { NOTAS: } \\
\text { 1) CAMADA SEMIRREDUTORA para tensões selecionadas intermediárias devem ser obtidas por interpolaçã } \\
\text { 2) Será usada extrapolação linear. }\end{array}$} \\
\hline
\end{tabular}




\subsubsection{FILTRAÇÃO no CONJUNTO-FONTE DE RADIAÇÃO X}

A respeito da FILTRAÇÃO, o CONJUNTO-FONTE DE RADIAÇÃO $X$ deve atender as seguintes prescrições:

- CONJUNTO-FONTE DE RADIAÇÃO X pode ser dotado de meios para montar, desmontar ou selecionar, um ou mais FILTROS ADICIONAIS, sem a utilização de FERRAMENTAS.

Quando existir qualquer um de tais FILTROS ADICIONAIS selecionáveis, devem estar conformes as seguintes prescrições:

a) devem ser identificáveis quando em posição de UTILIZAÇÃO NORMAL;

b) se a presença de FILTROS ADICIONAIS selecionáveis é necessária para atender as prescrições de FILTRAÇÃO TOTAL no EQUIPAMENTO DE RAIOS X, dadas em 29.201.5, devem existir meios que permitam detectar a presença do FILTRO ADICIONAL selecionado apropriado, pelo sistema de controle do GERADOR DE ALTA TENSÃO associado;

Nota - Esta prescrição para um INTERTRAVAMENTO é de especial importância no EQUIPAMENTO DE RAIOS X para mamografia. Devido a isso, não existem prescrições para uma FILTRAÇÃO COM EQUIVALÊNCIA DE QUALIDADE mínima, por materiais irremovíveis ou pela existência de FILTROS ADICIONAIS fixos no CONJUNTO-EMISSOR DE RADIAÇÃO X em questão.

- os DOCUMENTOS ACOMPANHANTES devem incluir, nas INSTRUÇÕES DE MONTAGEM para aplicações particulares, INSTRUÇÕES para obter a FILTRAÇÃO TOTAL exigida, para estar em conformidade com 29.201 .5 em relação ao EQUIPAMENTO DE RAIOS X em questão.

A conformidade deve ser verificada por inspeção, pelo exame dos DOCUMENTOS ACOMPANHANTES e pela aplicação do ensaio descrito em 29.201.8, conforme apropriado.

\subsubsection{FILTRAÇÃO TOTAL NO EQUIPAMENTO DE RAIOS X}

No EQUIPAMENTO DE RAIOS $X$ a FILTRAÇÃO TOTAL resultante de materiais situados no FEIXE DE RAIOS $X$ incidente no PACIENTE deve ser:

- no EQUIPAMENTO DE RAIOS X especificado exclusivamente para mamografia, com TENSÃO DO TUBO DE RAIOS X nominal não superior a $50 \mathrm{kV}$, quando configurado para operar com ALVO de molibdênio, deve oferecer FILTRAÇÃO não inferior àquela decorrente do FILTRO SELETIVO EM ARESTA de molibdênio, com 0,03 mm de espessura;

- no EQUIPAMENTO DE RAIOS X especificado exclusivamente para mamografia, com TENSÃO DO TUBO DE RAIOS X NOMINAL não superior a $50 \mathrm{kV}$, quando configurado para operar com ALVO de um material diferente do molibdênio, a FILTRAÇÃO COM EQUIVALÊNCIA DE QUALIDADE não deve oferecer FILTRAÇÃO inferior àquela decorrente dos materiais que, em combinação com o material do ALVO, permitem uma conformidade com 29.201.2.

- no EQUIPAMENTO DE RAIOS X especificado exclusivamente para RADIOGRAFIA odontológica, com TENSÃO DO TUBO DE RAIOS X NOMINAL não superior a $70 \mathrm{kV}$, a FILTRAÇÃO COM EQUIVALÊNCIA DE QUALIDADE deve oferecer FILTRAÇÃO não inferior a $1,5 \mathrm{~mm} \mathrm{Al}$;

- no EQUIPAMENTO DE RAIOS X não incluído nas condições acima, a FILTRAÇÃO COM EQUIVALÊNCIA DE QUALIDADE não inferior a 2,5 mm AI. 
A FILTRAÇÃO ADICIONAL presente originariamente no CONJUNTO-FONTE DE RADIAÇÃO X, formando uma parte integrante do EQUIPAMENTO DE RAIOS X pode ser reduzida, desde que a FILTRAÇÃO TOTAL no EQUIPAMENTO DE RAIOS X não permaneça inferior aos valores exigidos acima e que seja mantida a conformidade com os valores da CAMADA SEMIRREDUTORA em 29.201.2.

A conformidade é verificada por inspeção, pelo exame dos DOCUMENTOS ACOMPANHANTES e pela aplicação dos ensaios descritos em 29.201.7, 29.201.8 e 29.201.9, conforme apropriada.

\subsubsection{Indicação das propriedades do FILTRO}

As propriedades do FILTRO devem ser indicadas da seguinte forma:

- CONJUNTO-EMISSOR DE RAIOS $X$ deve ser marcado com a FILTRAÇÃO COM EQUIVALÊNCIA DE QUALIDADE dos materiais irremovíveis ou com a espessura dos materiais em questão, junto com os seus símbolos químicos;

- FILTROS ADICIONAIS, inclusive FILTROS EM ARESTA, devem ser marcados de tal forma que a espessura e o símbolo químico de cada material utilizado possa ser indicado. A marcação pode ser dada em forma de uma referência a declaração destas particularidades nos DOCUMENTOS;

- Para todos os FILTROS ADICIONAIS, os DOCUMENTOS ACOMPANHANTES devem declarar a FILTRAÇÃO COM EQUIVALÊNCIA DE QUALIDADE, e em espessuras de alumínio ou de outro material de referência adequado, junto com a QUALIDADE DE RADIAÇÃO utilizada para a sua determinação. Qualquer valor de FILTRAÇÃO COM EQUIVALÊNCIA DE QUALIDADE dado para um FILTRO EM ARESTA, deve ser relacionado com a descontinuidade na faixa de baixa energia;

- Camadas fixas de material no FEIXE DE RADIAÇÃO $X$ incidente no paciente, diferentes daquelas dos FILTROS ADICIONAIS e dos materiais irremovíveis no CONJUNTO-EMISSOR DE RADIAÇÃO $X$, devem ser marcadas para mostrar a FILTRAÇÃO COM EQUIVALÊNCIA DE QUALIDADE em espessura de alumínio, junto com a QUALIDADE DE RADIAÇÃo utilizada para a sua determinação. A marcação pode ser dada na forma de referência à declaração destas particularidades nos DOCUMENTOS ACOMPANHANTES. Tais camadas não necessitam serem marcadas se sua FILTRAÇÃO COM EQUIVALÊNCIA DE QUALIDADE não adicionar mais que $0,2 \mathrm{mmAl}$ e se elas não se destinam a ser levadas em consideração como parte da FILTRAÇÃO TOTAL exigida para conformidade com 29.201.5.

A conformidade é verificada por inspeção, conforme adequado, do CONJUNTOEMISSOR DE RADIAÇÃO X, materiais de filtração e FILTROS ADICIONAIS e por exame dos DOCUMENTOS ACOMPANHANTES.

\subsubsection{Ensaio para FILTRAÇÃO por materiais irremovíveis}

Determine a FILTRAÇÃO por materiais irremovíveis num CONJUNTO-EMISSOR DE RADIAÇÃO X, acrescentando os valores da FILTRAÇÃO COM EQUIVALÊNCIA DE QUALIDADE de cada uma das camadas não removíveis do material que intercepta o FEIXE DE RADIAÇÃO X. Se esta informação não pode ser obtida, determine a FILTRAÇÃO COM EQUIVALÊNCIA DE QUALIDADE de acordo com os Itens 3 e 4 da Publicação IEC 522. Se a TENSÃO DO TUBO DE RAIOS X NOMINAL para o CONJUNTO-EMISSOR DE RADIAÇÃO $X$ exceder $70 \mathrm{kV}$, utilize uma TENSÃO DO TUBO DE RAIOS $X$ de $70 \mathrm{kV}$; nos outros casos utilize a TENSÃO DO TUBO DE RAIOS X NOMINAL. 


\subsubsection{Ensaio para FILTROS ADICIONAIS e materiais (que interceptam o FEIXE DE RADIAÇÃO X)}

Determine a FILTRAÇÃO COM EQUIVALÊNCIA DE QUALIDADE dos FILTROS ADICIONAIS e dos materiais (que interceptam o FEIXE DE RADIAÇÃO X) formando parte da FILTRAÇÃO TOTAL sob CONDIÇÕES DE FEIXE ESTREITO, com a espessura de alumínio que resulta na mesma primeira CAMADA SEMIRREDUTORA como o material submetido ao ensaio. Para a medição, utilize um FEIXE DE RADIAÇÃO com a primeira camada SEMIRREDUTORA de $2,5 \mathrm{~mm}$ Al obtida com uma TENSÃO DE TUBO DE RAIOS X de $70 \mathrm{kV}$ com a ONDULAÇÃO PORCENTUAL inferior a $10 \%$.

Se a FILTRAÇÃO COM EQUIVALÊNCIA DE QUALIDADE de Um FILTRO EM ARESTA é para ser determinada, utilize a QUALIDADE DE RADIAÇÃO apropriada a descontinuidade na faixa de baixa energia.

\subsubsection{Ensaio para CAMADA SEMIRREDUTORA}

Meça a primeira CAMADA SEMIRREDUTORA sob CONDIÇÕES DE FEIXE ESTREITO, com o EQUIPAMENTO DE RAIOS $X$ operando em valores selecionados de TENSÃO DO TUBO DE RAIOS $X$ dentro da faixa operacional adequada especificada, indicada na segunda coluna da Tabela 204, com correspondentes PARÂMETROS DE APLICAÇÃO DE CARGA na faixa de UTILIZAÇÃO NORMAL.

Para EQUIPAMENTO DE RAIOS $X$ com GERADOR DE ALTA TENSÃO A DESCARGAS DE CAPACITORES, efetua-se cada medição com um valor selecionado de TENSÃO DO TUBO DE RAIOS X INICIAL, com O PRODUTO CORRENTE TEMPO máximo, selecionável para tal tensão em UTILIZAÇÃO NORMAL.

\subsection{ATENUAÇÃO do FEIXE DE RADIAÇÃO X}

Nota - De 29.206.1 a 29.206.3 dizem respeito à necessidade de evitar excessiva ATENUAÇÃO do FEIXE DE RADIAÇÃO $X$ por materiais interpostos entre o PACIENTE e o RECEPTOR DE IMAGEM DA RADIAÇÃO $X$, que possam causar níveis desnecessariamente elevados de DOSE ABSORVIDA e de RADIAÇÃO ESPALHADA.

\subsubsection{ATENUAÇÃO por itens no FEIXE DE RADIAÇÃO X}

O EQUIVALENTE DE ATENUAÇÃO dos itens relacionados na Tabela 206, quando fazem parte do EQUIPAMENTO DE RAIOS $X$ e localizados na passagem do FEIXE DE RADIAÇÃO X entre O PACIENTE e O RECEPTOR DE IMAGEM DE RADIAÇÃO X, não deve exceder os valores máximos aplicáveis, apresentados na Tabela 206.

A conformidade é verificada pelo ensaio descrito em 29.206.3 
Tabela 206 - EQUIVALENTE DE ATENUAÇÃO dos itens no FEIXE DE RADIAÇÃO X

\begin{tabular}{|c|c|}
\hline Componente & $\begin{array}{l}\text { EQUIVALENTE DE } \\
\text { ATENUAÇÃO máxima } \\
\text { mmAl }\end{array}$ \\
\hline \multicolumn{2}{|l|}{ Componentes para mamografia: } \\
\hline $\begin{array}{l}\text { Mesa suporte de EQUIPAMENTO DE RAIOS X para mamografia (total de } \\
\text { todas as camadas) }\end{array}$ & 0,3 \\
\hline \multicolumn{2}{|l|}{ Componentes não utilizados para mamografia } \\
\hline Painel frontal do suporte do chassis (total de todas as camadas) & 1,2 \\
\hline Painel frontal do CAMBIADOR DE FILMES (total de todas as camadas) & 1,2 \\
\hline Maca & 1,2 \\
\hline SUPORTE DE PACIENTE, estacionário, sem juntas articuláveis & 1,2 \\
\hline $\begin{array}{l}\text { SUPORTE DE PACIENTE, móvel, sem juntas articuláveis (incluindo } \\
\text { camadas estacionárias) }\end{array}$ & 1,7 \\
\hline $\begin{array}{l}\text { SUPORTE DE PACIENTE, com placa radio-transparente, tendo uma } \\
\text { junta articulável }\end{array}$ & 1,7 \\
\hline $\begin{array}{l}\text { SUPORTE DE PACIENTE, com placa radio-transparente, tendo duas ou } \\
\text { mais juntas articuláveis }\end{array}$ & 2,3 \\
\hline SUPORTE DE PACIENTE, em balanço & 2,3 \\
\hline \multicolumn{2}{|c|}{$\begin{array}{l}\text { Notas: } \\
\text { a) Dispositivos tais como DETECTORES DE RADIAÇÃO não são incluídos nos componentes desta } \\
\text { lista. } \\
\text { b) Prescrições são dadas em relação às propriedades de ATENUAÇÃo de chassis radiográficos na } \\
\text { Publicação } 406 \text { da IEC, de ÉCRANS REFORÇADORES, no Anexo A da Publicação } 658 \text { da IEC e de } \\
\text { GRADES ANTI-ESPALHAMENTO na Publicação } 627 \text { da IEC. }\end{array}$} \\
\hline
\end{tabular}

\subsubsection{Informações nos DOCUMENTOS ACOMPANHANTES}

Os DOCUMENTOS ACOMPANHANTES devem declarar o valor máximo do EQUIVALENTE DE ATENUAÇÃO de cada um dos itens apresentados na Tabela $206 \mathrm{e}$ fazendo parte do EQUIPAMENTO DE RAIOS $X$ em consideração.

Para EQUIPAMENTO DE RAIOS X para fins diagnósticos, especificado para utilização combinada com ACESSÓRIOS ou outros materiais que não fazem parte do mesmo ou de um outro EQUIPAMENTO DE RAIOS X para fins diagnósticos, as INSTRUÇÕES DE UTILIZAÇÃO devem incluir um alerta para a possibilidade de efeitos adversos oriundos de componentes localizados no FEIXE DE RADIAÇÃO X (por exemplo, partes da mesa cirúrgica).

A conformidade é verificada pelo exame dos DOCUMENTOS ACOMPANHANTES.

\subsubsection{Ensaio de EQUIVALENTE DE ATENUAÇÃO}

Utilizando um FEIXE DE RADIAÇÃO X com parametros de acordo com a Tabela 207, determine o EQUIVALENTE DE ATENUAÇÃO como sendo a espessura de alumínio que fornece o mesmo grau de ATENUAÇÃO que o material sob consideração, de medições de KERMA NO AR sob CONDIÇÕES DE FEIXE ESTREITO.

Tabela 207 - Parâmetros para ensaios de EQUIVALENTE DE ATENUAÇÃO

\begin{tabular}{|l|c|c|c|}
\hline $\begin{array}{c}\text { Aplicação do componente } \\
\text { sob ensaio }\end{array}$ & $\begin{array}{c}\text { TENSÃO DO TUBO DE } \\
\text { RAIOS X (kV) }\end{array}$ & $\begin{array}{c}\text { ONDULAÇÃO PORCENTUAL } \\
\text { máxima (\%) }\end{array}$ & $\begin{array}{c}\text { PRIMEIRA CAMADA } \\
\text { SEMIRREDUTORA (mmAl) }\end{array}$ \\
\hline Mamográfico & 30 & 10 & 0,3 \\
\hline Não-mamográfico & 100 & 10 & 3,7 \\
\hline
\end{tabular}




\section{APÊNDICE 2 ABNT NABR IEC 60601-1-3: 2011}

\section{7 - Qualidade de radiação}

\section{1 - Camadas semirredutoras e filtração total em equipamentos de raios $X$}

A qualidade DE RADIAÇÃo do FEIXE DE RAIOS $X$ fornecido pelo EQUIPAMENTO DE RAIOS $X$ deve ser apropriada para a produção das imagens destinadas sem que se administre DOSES desnecessariamente altas ao PACIENTE.

A FILTRAÇÃO TOTAL no feixe precisa ser suficiente para atingir o objetivo precedente. Prescrições para uma FILTRAÇÃo mínima são fornecidas aqui em termos de FILTRAÇÃo TOTAL DE QUALIDADE EQUIVALENTE ou da primeira CAMADA SEMIRREDUTORA para a TENSÃO DO TUBO DE RAIOS $X$ especificada.

Nos EQUIPAMENTOS DE RAIOS X, para todas as configurações disponíveis na UTILIZAÇÃo NORMAL, a primeira CAMADA SEMIRREDUTORA atingida no FEIXE DE RAIOS $\boldsymbol{X}$ incidente sobre o PACIENTE não deve ser menor do que os valores mínimos permissíveis fornecidos na Tabela 3, a não ser que O EQUIPAMENTO DE RAIOS $X$ esteja isento por uma norma particular.

Alternativamente ao parágrafo anterior, a FILTRAÇÃO TOTAL decorrente dos materiais no FEIXE DE RAIOS $X$ incidente sobre o PACIENTE não deve ser menor do que uma FILTRAÇÃO COM EQUIVALÊNCIA DE QUALIDADE de $2,5 \mathrm{~mm}$ Al, a não ser que o EQUIPAMENTO DE RAIOS $X$ esteja isento por uma norma particular.

Tabela 3 - CAMADA SEMIRREDUTORA em EQUIPAMENTOS DE RAIOS $X$

\begin{tabular}{|c|c|c|}
\hline & $\begin{array}{l}\text { TENSÃO DO TUBO DE RAIOS } X \\
\text { kV }\end{array}$ & $\begin{array}{c}\text { Primeira CAMADA SEMIRREDUTORA } \\
\text { mínima permissível } \\
\mathrm{mm} \mathrm{Al}\end{array}$ \\
\hline & 50 & 1,8 \\
\hline & 60 & 2,2 \\
\hline & 70 & 2,5 \\
\hline & 80 & 2,9 \\
\hline & 90 & 3,2 \\
\hline & 100 & 3,6 \\
\hline & 110 & 3,9 \\
\hline & 120 & 4,3 \\
\hline & 130 & 4,7 \\
\hline & 140 & 5,0 \\
\hline & 150 & 5,4 \\
\hline \multicolumn{3}{|c|}{$\begin{array}{l}\text { - CAMADAS SEMIRREDUTORAS para outras tensões devem ser obtidas através de } \\
\text { interpolação ou extrapolação linear. } \\
\text { - Estes valores da CAMADA SEMIRREDUTORA correspondem a uma FILTRAÇÃO TOTAL de } \\
2,5 \mathrm{~mm} \text { Al para EQUIPAMENTO DE RAIOS X, operando com uma TENSÃO DO TUBO DE } \\
\text { RAIOS X de potencial constante. }\end{array}$} \\
\hline
\end{tabular}

A conformidade é verificada através dos ensaios descritos em 7.4, 7.5 e 7.6 e inspeções. 


\section{2 - Forma de onda da tensão do tubo de raios $X$}

A distribuição das TENSÕES NO TUBO DE RAIOS X durante a APLICAÇÃO DE CARGA não deve produzir um aumento excessivo da RADIAÇÃo de baixa energia no FEIXE DE RAIOS X. Isso aplica-se particularmente a:

- fase de elevação da TENSÃO DO TUBO DE RAIOS X;

- fase de redução da TENSÃO DO TUBO DE RAIOS X; e

- o formato e a amplitude da ONDULAÇÃO DA TENSÃO DO TUBO DE RAIOS X.

A forma de onda da TENSÃO DO TUBO DE RAIOS X que, em conjunção com a FILTRAÇÃO TOTAL nO EQUIPAMENTO DE RAIOS X, resulta em uma dose de RADIAÇÃO aceitável para a UTILIZAÇÃO DESTINADA deve ser determinada no ARQUIVO DE GERENCIAMENTO DE RISCO ou através da aplicação de uma norma particular.

A conformidade é verificada através da inspeção.

\section{3 - Indicação das propriedades do filtro}

Devem ser fornecidos meios para indicar:

- a FILTRAÇÃo PERMANENTE no FEIXE DE RAIOS X;

- a espessura e composição química de cada FILTRO ADICIONAL.

As propriedades do FILTRO devem ser indicadas da seguinte forma:

- Os CONJUNTOS-EMISSORES DE RADIAÇÃO X devem ser marcados com SUa FILTRAÇÃO PERMANENTE ou com a espessura dos materiais em questão, junto com seus símbolos químicos.

- Quando acessíveis ao OPERADOR, os FILTROS ADICIONAIS, incluindo o FILTRO SELETIVO EM ARESTAS, devem ser marcados de forma que a espessura e o símbolo químico de cada material empregado sejam identificados. A marcação pode ser efetuada na forma de uma referência às informações destes particulares nos DOCUMENTOS ACOMPANHANTES.

- Para todos os filtros adicionais, os documentos acompanHANTES devem informar a FILTRAÇÃO COM EQUIVALÊNCIA DE QUALIDADE em espessura do alumínio ou outro material de referência apropriado, junto com a QUALIDADE DE RADIAÇÃo utilizada na sua determinação (Exemplo: 0,3 mm Al 75 kV/CSR 2,7 $\mathrm{mm}$ Al). Qualquer valor de FILTRAÇÃO COM EQUIVALÊNCIA DE QUALIDADE dado para um FILTRO SELETIVO EM ARESTA deve ser relacionado ao lado de baixa energia da descontinuidade.

- Camadas fixas de materiais no fEIXE DE RAIOS X incidente sobre o PACIENTE, diferentes dos FILTROS ADICIONAIS e materiais irremovíveis dos conJUNTOS- 
EMISSORES DE RADIAÇÃO $X$, devem ser marcados de forma a exibir a FILTRAÇÃO COM EQUIVALÊNCIA DE QUALIDADE em espessura do alumínio junto com a QUALIDADE DE RADIAÇÃo utilizada na sua determinação. A marcação pode ser efetuada na forma de uma referência às informações destas indicações nos DocumENTos ACOMPANHANTES. Tais camadas não precisam ser rotuladas se adicionarem, juntas, não mais do que uma FILTRAÇÃo COM EQUIVALÊNCIA DE QUALIDADE de $0,2 \mathrm{~mm}$ Al e não forem destinadas a serem consideradas como parte da FILTRAÇÃo TOTAL prescrita para conformidade com o $4^{\circ}$ parágrafo da subcláusula 7.1.

- Sempre que o EQUIPAMENTO DE RAIOS X tiver provisões para selecionar FILTROS ADICIONAIS por controle remoto ou sistemas automáticos, o FILTRO ADICIONAL selecionado deve ser indicado no PAINEL DE CONTROLE.

A conformidade é verificada através da inspeção, da forma apropriada, dos CONJUNTOS-EMISSORES DE RADIAÇÃO $X$, dos materiais de filtração e dos FILTROS ADICIONAIS e através do exame dos DOCUMENTOS ACOMPANHANTES.

\section{4 - Ensaio para filtração por materiais não-removíveis}

Determine a FILTRAÇÃO representada por materiais irremovíveis em um CONJUNTOFONTE DE RADIAÇÃO $X$ somando os valores da FILTRAÇÃO COM EQUIVALÊNCIA DE QUALIDADE de cada camada de material irremovível que intercepta o FEIXE DE RAIOS $X$. Se esta informação não puder ser obtida, determine a FILTRAÇÃO COM EQUIVALÊNCIA DE QUALIDADE de acordo com a IEC 60522.

\section{5 - Ensaio para filtros adicionais e materiais}

Determine a FILTRAÇÃO COM EQUIVALÊNCIA DE QUALIDADE dOS FILTROS ADICIONAIS e de outros materiais que façam parte da FILTRAÇÃO TOTAL, SOb as CONDIÇÕES DE FEIXE ESTREITO, como a espessura de alumínio que resultar na mesma primeira CAMADA SEMIRREDUTORA que o material sendo ensaiado. fornecida na Tabela 3.

Se a FILTRAÇÃO COM EQUIVALÊNCIA DE QUALIDADE de UT FILTRO SELETIVO EM ARESTA tiver que ser determinada, utilize uma QUALIDADE DE RADIAÇÃO apropriada para o lado de baixa energia da descontinuidade.

\section{6 - Ensaio para camada semirredutora}

Meça a primeira CAMADA SEMIRREDUTORA SOb as CONDIÇÕES DE FEIXE ESTREITO COT O EQUIPAMENTO DE RAIOS $X$ operando com os valores selecionados para a TENSÃO DO TUBO DE RAIOS $X$ fornecidos na Tabela 3 com os PARÂMETROS DE APLICAÇÃO DE CARGA correspondentes para a faixa da UTILIZAÇÃO NORMAL.

10 - Atenuação do feixe de raios $X$ entre o paciente e o receptor da imagem por raios $X$ 10.1 - Geral

Os EQUIPAMENTOS DE RAIOS $X$ devem ser projetados de forma que a ATENUAÇÃo do FEIXE DE RAIOS $X$ pelo material interposto entre O PACIENTE e O RECEPTOR DA IMAGEM 
POR RAIOS X seja mantida tão baixa quanto razoavelmente possível de forma a evitar que doses desnecessariamente altas sejam fornecidas ao PACIENTE e, através da RADIAÇÃO PARASITA, aO OPERADOR. Valores da ESPESSURA EQUIVALENTE DE ATENUAÇÃO e das CONDIÇÕES DE RADIAÇÃO para ensaios prescritos para a UTILIZAÇÃO DESTINADA devem ser determinados no ARQUIVO DE GERENCIAMENTO DE RISCO ou através da aplicação de uma norma particular.

A conformidade é verificada através do exame do ARQUIVO DE GERENCIAMENTO DE RISCO.

\section{2 - Informações nos documentos acompanhantes}

Os DOCUMENTOS ACOMPANHANTES devem informar o valor máximo da ESPESSURA EQUIVALENTE DE ATENUAÇÃo de cada item interposto entre o PACIENTE e o RECEPTOR DA IMAGEM POR RAIOS X que faça parte do EQUIPAMENTO DE RAIOS $X$.

Em EQUIPAMENTOS DE RAIOS X DIAGNÓSTICO especificados para utilização em combinação com ACESSÓRIOS ou outros itens que não façam parte do mesmo ou de outros EQUIPAMENTOS DE RAIOS X DIAGNÓSTICO, as instruções de utilização devem incluir um parágrafo chamando atenção para os possíveis efeitos adversos decorrentes dos materiais localizados no FEIXE DE RAIOS X (por exemplo partes de uma mesa cirúrgica).

A conformidade é verificada através do exame dos DOCUMENTOS ACOMPANHANTES. 


\section{APÊNDICE 3}

IEC 60522:1976

$-5-$

INHERENT FILTRATION OF AN X-RAY TUBE ASSEMBLY

1. Scope

This standard deals with the concept of inheren filtration of $X$-rav tube assemblies, its definition. methods of indication and its determination, and the statement of inherem fitration measured according to this standard.

These methods are intended for the determination and statement of the value of inherent filtration for an $X$-ray tube assembly in order to permit the establishment of the minimum total filtration in an X-ray equipment required for purpoșes of protection of patients against low-energy ionizing radiation having no clinical value (diagnostic or therapeutic).

The method given is not intended to be applied for measuring inherent filtration or required total filtration in an actual $X$-ray installation.

2. Terminology

2.1 Degree of requirements

In this standard the words:

"shall", "should" and "may" have the following meanings:

"shall" - mandatory, for compliance with this standard;

"should" - strongly recommended;

"may" - acceptable.

2.2 Definition

Inherent filtration:

The filtration effected by the irremovable materials of an $X$-ray tube assembly through which the useful beam passes before emerging from the $X$-ray tube housing.

\section{Indication - Value and reference material}

The value of inherent filtration of an X-ray tube assembly operating under specified conditions is indicated in thickness of a reference material which, when placed in a negligibly filtered beam from an $X$-ray ube operating under the same specified conditions of value and waveform of $X$-ray tube potential difference, target material and target angle, filters the beam so as to have the same first half-value layer (that is quality equivalent filtration) as the beam from the $X$-ray tube assembly under consideration.

The inherent filtration shall be stated:

- in thickness of beryllium or some other substance of weak filtration for X-ray tube assemblies when the window of the $X$-ray tube and the window of the $X$-ray tube housing are composed essentially of beryllium or this other substance;

- in thickness of aluminium for $X$-ray tube assemblies for operation at $X$-ray tube potential differences up to and including $200 \mathrm{kV}$;

- in thickness of copper for $X$-ray nube assemblies for operation at $X$-ray tube potential differences from $150 \mathrm{kV}$ up to and including $400 \mathrm{kV}$.

The stated value of inherent filtration shall be equal to or less than the measured value. It should be within the range of 0 to $15 \%$ below the measured value.

The thickness of the reference material shall be expressed in millimetres, the reference material by its chemical symbol, an $X$-ray mbe potential difference in kilovolts. 


\section{Measurement}

The inherent filtration shall be determined by measurement of the first half-value layer on the central axis of the beam, and by comparison with the half-value layer for radiation from an X-ray tube with a window of beryllium (or other material of negligible filtration) and with the same target material and target angle and operating at an $X$-ray tube potential difference of the same value and waveform, and at the same $X$-ray tube current.

The measurement shall be made at half the maximum potential difference (unless otherwise stated).

Notes 1 - If an $X$-ray tube with the same target angle is not available, an $X$-ray tube may be adjusted by titting to give a beam of radiation from the same stated target anyle.

2. - A method in which the filtration of the irremovabie materials of the subject $X$-ray me housing through which the usefiul beam passes is measured is acceptable, but this involves the provision of substitute materials or destruction of the $X$-ray tube to enable the component parts to be handled.

\section{Statements of compliance}

If compliance with this standard for the determination and the indication of a value of inherent filtration is to be stated, the value of the inherent filtration shall be indicated as given below.

For the marking on $X$-ray tube assemblies in combination with the graphical symbol * No. ... IEC ..., the values are given without adding their units, millimetres and kilovolts.

Where the marking on $X$-ray tube assemblies states the maximum potential difference (maximum voltage), indication of the half of the maximum potential difference (maximum voltage) used for the determination of the inherent filtration is not necessary.

The statement of compliance shall conform to the following examples:

- In accompanying documents:

inherent filtration $1.2 \mathrm{~mm} \mathrm{Al} / 75 \mathrm{kV}$ IEC 522/1976.

- On $X$-ray tube assemblies, as appropriate:

for measurement at half the stated maximum potential difference (maximum voltage), according to this standard:

* 1.2 Cu IEC 522/1976;

for measurement at other $X$-ray tube potential differences, e.g. at $80 \mathrm{kV}$ :

* $1.0 \mathrm{Al} / 80$ IEC $522 / 1976$.

* Graphical symbol under consideration. 


\section{APÊNDICE $4 \quad$ IEC60522: 1999}

\section{Measurement of PERMANENT FILTRATION}

When, in accordance with the requirements in clause 5, the PERMANENT FILTRATION is to be expressed in terms of the actual filtering material (e.g. beryllium), the nature and thickness of the material present shall be determined or verified by inspection. In other cases, the following test shall be used to determine the PERMANENT FILTRATION of an X-RAY TUBE ASSEMBLY to be indicated or stated in accordance with this standard.

\subsection{General}

The PERMANENT FILTRATION is determined by measuring the QUALITY EQUIVALENT FILTRATION of samples of the permanently fixed materials, used in the construction of the $X$ RAY TUBEASSEMBLY, that intercept the X-RAY BEAM. Where appropriate, a composite sample replicating the combination of the various materials and their thicknesses, as actually used in the construction, can be tested. Alternatively, the PERMANENT FILTRATION can be computed from measurements on samples of the individual materials concerned, provided that: 60522 @ IEC:1999(E) - 7 -

- the reference material is the same for each sample and,

- the RADIATION QUALITY of the X-RAY BEAM used for the determination is adjusted to compensate for the absence of any components of the PERMANENT FILTRATION missing from the sample and normally located between the sample and the FOCAL SPOT.

NOTE - The result of the determination is valid only for a particular combination of materials, as tested. In manufacture, the composition and thicknesses of materials actually used must be controlled within appropriate limits, in order to maintain compliance with any stated value of PERMANENT FILTRATION.

\subsection{Test sample}

Use a test sample, replicating, in accordance with 4.1, either the complete composition of layers of different materials, or a layer of an individual material, as used in the construction of the X-RAY TUBE ASSEMBLY concerned to effect the whole or part of its PERMANENT FILTRATION.

\subsection{Generation of the X-RAY BEAM for measurement}

To generate the X-RAY BEAM for measurement, use an X-RAY TUBE with a target of the same material as the X-RAY TUBE ASSEMBLY under test at an X-RAY TUBE VOLTAGE with a PERCENTAGE RIPPLE not exceeding 10 and a value chosen as follows:

a) for X-RAY TUBE ASSEMBLIES in which the PERMANENT FILTRATION contains a material with a K-edge absorption energy at $19 \mathrm{keV}$ or above, use an X-RAY TUBE VOLTAGE corresponding to the K-edge energy of the material, for example $20 \mathrm{kV}$ for molybdenum with a K-edge at 19,99 keV; otherwise 
b) for X-RAY TUBE ASSEMBLIES designed for a narrow range of X-RAY TUBE VOLTAGE (e.g. CT-application), the NOMINAL X-RAY TUBE VOLTAGE; or

c) for X-RAY TUBE ASSEMBLIES with a NOMINAL X-RAY TUBE VOLTAGE not exceeding $65 \mathrm{kV}$, the NOMINAL X-RAY TUBE VOLTAGE; or d) for X-RAY TUBE ASSEMBLIES with a NOMINAL X-RAY TUBE VOLTAGE exceeding $65 \mathrm{kV}, 75 \mathrm{kV}$ or approximately half the NOMINAL X-RAY TUBE VOLTAGE, whichever is the greater. It is desirable to avoid testing close to the absorption edge of tungsten. For testing with a composite sample, use an X-RAY BEAM with negligible TOTAL FILTRATION (e.g. a beryllium window). For testing with a sample of a single material, add an appropriate thickness of the reference material between the material under test and the FOCAL SPOT. This is to compensate for the effect on the RADIATION QUALITY at the ENTRANCE SURFACE of the sample of omitting any layers of material forming part of the actual PERMANENT FILTRATION.

\subsection{RADIATION DETECTOR}

Use a RADIATION DETECTOR with a response that does not vary significantly over the energy range involved.

\subsection{Composition of reference materials}

Values of HALF-VALUE LAYER and QUALITY EQUIVALENT FILTRATION determined in accordance with this standard apply to reference materials of the following composition (designated by Cu 99,9 according ISO 2092):

- aluminium of $99,9 \%$ purity or higher and density $2,70 \mathrm{~g} \mathrm{~cm}-3$;

- copper of at least $99,9 \%$ purity or higher and a density of $8,90 \mathrm{~g} \mathrm{~cm}-3$.

\subsection{Method of measurement}

Measure the first HALF VALUE LAYER of the X-RAY BEAM under NARROW BEAM CONDITIONS, with the sample placed close to the FOCAL SPOT. Determine the thickness of the reference material $-8-60522$ C IEC:1999(E) that is required to produce the same HALF VALUE LAYER under the same beam conditions. The resulting thickness of the reference material is the QUALITY EQUIVALENT FILTRATION of the sample.

If the sample is a composite one, representing all the materials comprising the PERMANENT FILTRATION, the result is also the value of the PERMANENT FILTRATION for the X-RAY TUBE ASSEMBLY concerned. Alternatively, add the values obtained (with the same reference material and primary beam conditions) for the QUALITY EQUIVALENT FILTRATION of samples representing all the different single materials forming part of the PERMANENT FILTRATION. Compliance with a stated value of PERMANENT FILTRATION is achieved if the MEASURED VALUE determined in this test is not less than the stated value and does not exceed the stated value by more than $30 \%$. 


\section{Indications and statements of PERMANENT FILTRATION}

For statements of compliance with this standard, the value of the PERMANENT FILTRATION of an X-RAY TUBE ASSEMBLY shall be expressed in millimetres the thickness of:

- the material concerned, if the PERMANENT FILTRATION consists of a single material (e.g. beryllium), otherwise - aluminium for X-RAY TUBE ASSEMBLIES with a NOMINAL X-RAY TUBE VOLTAGE not exceeding $150 \mathrm{kV}$, together with the X-RAY TUBE VOLTAGE used in the determination; or - copper for X-RAY TUBE ASSEMBLIES with a NOMINAL X-RAY TUBE VOLTAGE exceeding $150 \mathrm{kV}$, together with the X-RAY TUBE VOLTAGE used for the determination.

Filtering or reference materials shall be described by their chemical symbols. The X-RAY TUBE VOLTAGE used for measurement, where applicable, shall be given in kilovolts. If an indication or statement of compliance with this standard is to be given, it shall take the applicable form, as given below as an example, which applies to a stated value of 1,2 mm determined with aluminium as the reference material at an X-RAY TUBE VOLTAGE of $75 \mathrm{kV}$ :

a) for written statements, for example in ACCOMPANYING DOCUMENTS:

Permanent Filtration 1,2 mm Al/75 kV IEC 60522/1999;

b) for markings on the X-RAY TUBE ASSEMBLY:

\section{$1,2 \mathrm{Al} / 75$}

NOTE 1 - In case a) above note that the units $\mathrm{mm}$ and $\mathrm{kV}$ are to be included.

NOTE 2 - Where the PERMANENT FILTRATION is to be stated in terms of the actual filtering material (e.g. beryllium) no X-RAY TUBE VOLTAGE is applicable. In all other cases, the voltage of determination is to be included. 


\section{REFERÊNCIAS BIBLIOGRÁFICAS}

[1] ASSOCIAÇÃO BRASILEIRA DE NORMAS TÉCNICAS. Equipamento eletromédico Parte 1: Prescrições gerais de segurança 3. Norma Colateral: Prescrições gerais para proteção contra radiação de equipamentos de raios $X$ para fins diagnósticos. ABNT, Rio de Janeiro, 2001 (NBR IEC 60601-1-3).

[2] ASSOCIAÇÃO BRASILEIRA DE NORMAS TÉCNICAS. Equipamento eletromédico Parte 1: Prescrições gerais de segurança 3. Norma Colateral: Prescrições gerais para proteção contra radiação de equipamentos de raios $X$ para fins diagnósticos. ABNT, Rio de Janeiro, 2011 (NBR IEC 60601-1-3).

[3] Instituto Nacional De Metrologia, Normalização e Qualidade Industrial. Disponível em: http://www.inmetro.gov.br/qualidade/index.asp. Consulta em 05/03/2012.

[4] ABNT. NBR ISO 9000:2008. Sistema de gestão da qualidade: requisitos. Rio de dezembro, 2008.

[5] Instituto Nacional De Metrologia, Normalização e Qualidade Industrial. Requisitos de avaliação da conformidade de equipamentos elétricos sob regime de vigilância sanitária. INMETRO Portaria n. 350, de 06 de Setembro de 2010. Diasponível em HTTP://www.inmetro.gov.br/legislacao/rtac/pdf/RTAC1516.pdf. Consulta em 05 de março de 2012.

${ }^{[6]}$ BRASIL. Congresso. Senado. Resolução $n^{0} 32$, de 29 de maio de 2007. Dispõe sobre a certificação complusória dos equipamentos elétricos sob regime de Vigilância Sanitária e dá outras providências. Revista dos Tribunais, São Paulo, jan/dez 2007. Suplemento de Legislação.

[7] Instituto Nacional De Metrologia, Normalização e Qualidade Industrial. Disponível em: http://www.inmetro.gov.br/qualidade/prodCompulsorios.asp. Consulta em 05/03/2012.

${ }^{[8]}$ ASSOCIAÇÃO BRASILEIRA DE NORMAS TÉCNICAS. Equipamento eletromédico Parte 2-7:Prescrições particulares para segurança de geradores de alta tensão de geradores de raio $X$ para diagnóstico médico. ABNT, Rio de Janeiro, 2001 (NBR IEC 60601-2-7).

[9] ASSOCIAÇÃO BRASILEIRA DE NORMAS TÉCNICAS. Equipamento eletromédico Parte 2-28:Prescrições particulares para segurança aplicáveis aos conjunto-fontes de radiação $X$ e aos conjunto-emissores de radiação $X$ para diagnóstico médico. ABNT, Rio de Janeiro, 2001 (NBR IEC

60601-2-28).

[10] ASSOCIAÇÃO BRASILEIRA DE NORMAS TÉCNICAS. Equipamento eletromédico Parte 2-32: Prescrições particulares para segurança dos equipamentos associados aos equipamentos de raios $\boldsymbol{X}$. ABNT, Rio de Janeiro, 2001 (NBR IEC 60601-2-32).

[11] ASSOCIAÇÃO BRASILEIRA DE NORMAS TÉCNICAS. Equipamento eletromédico Parte 1: Requisitos gerais para segurança básica e desempenho essencial. ABNT, Rio de Janeiro, 2010 (NBR IEC 60601-1).

[12]. INTERNATIONAL ELECTROTECHNICAL COMMISSION. Inherent filtration of X-ray equipment. Pergamon Press, New York, 1999 (IEC-60522).

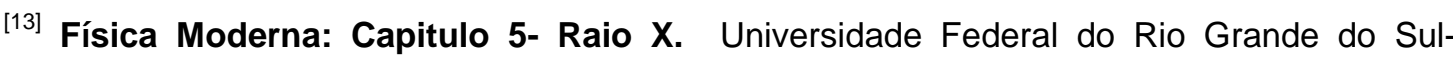
UFRGS. Disponível em: <http://www.if.ufrgs.br/tex/fis142/fismod/mod05/m_s01.html>. Acesso em: 05/03/2012. 
[14] INTERNATIONAL COMMISSION ON RADIATION UNITS AND MEASUREMENTS. Fundamental quantities and units for ionizing radiation. Bethesda, 1998 (ICRU Report 60).

[15] H. E. Johns. The Physics of Radiology. 4a ed. Charles C Thomas - Publisher, Springfield, Illinois, USA, 1983.

${ }^{[16]}$ ROS, R.A. Metodologia de controle de qualidade de equipamentos de raios X (nível diagnóstico) utilizados em calibração de instrumentos. 2000. 107 f. Dissertação (Mestrado em Ciências na Área de Tecnologia Nuclear - Aplicações)- Instituto de Pesquisas Energética e Nucleares - IPEN, São Paulo, 2000.

${ }^{[17]}$ BOTTARO, M. Estudo de envelhecimento de um tubo de raios $X$ por métodos não invasivos. Tese (Mestrado)- Instituto de Pesquisas Energéticas e Nucleares - IPEN. São Paulo, 2007.

[18] A.B. Wolbarst. Physics of Radiology. Appleton \& Lange, Norwalk, Connecticut, USA, 1993.

[19] JOURNAL OF NUCLEAR MEDICINE TECNOLOGY. Disponível em: http://tech.snmjournals .org/cgi/content-nw/full/32/3/139/F4. Consulta em 05/03/2012.

[20] INTERNATIONAL ATOMIC ENERGY AGENCY. Calibration of radiation protection monitoring instruments. Vienna, 2000. (Safety Reports Series 16).

${ }^{[21]}$ HORTON, J. L. New Jersey: Prentice- Handbook of radiation therapy physics. Hall, 1987.

${ }^{[22]}$ BUSHBERG, J. T.; SEIBERT, J. A.; JR.LEIDHOLDT, E. M.; BOONE, J. M. The essential physics of medical imaging. 2 ed. Philadelphia: Lippicott Williams \& Wilkins,2002. ISBN 0683-30118-7.

[23] HENDEE, W. R.; RITENOUR, E. R.; Medical imaging physics. 4ed. New York: WileyLiss,2002. ISBN 0-471-38226-4.

[24] NÓS E AS RADIAÇÕES IV. Disponível em: http://www.nuclear.radiologia.nom.br /trabalho/noseasiv/noseaiv.htm. Consulta em 05/03/2012.

${ }^{[25]}$ FRITZ, S.L.; LIVINGSTON, W.H. A comparison of computer and measured heel effect

for various target angles. Medical Physics, v.9, n.2, p.216-219. 1982.

${ }^{[26]}$ International Eletrotechnical Comission. Medical radiology - Terminology Descriptors: radiology, glossaries. Geneva Switzerland, 1984 (IEC 60788).

[27] UNIVERSITY OF BASEL. Disponível em: http://miac.unibas.ch/BIA/06-Xray.html\#(3). Consulta em 05/03/2012.

[28] MARGRAF CORPORATION. Disponível em: http://www.margrafcorp.com/aluminumfiltration.html. Consulta em 05/03/2012.

${ }^{[29]}$ BUSHONG,S.C. Manual de radiologia para Tecnólogos: Física, biologia y protección radiológica. 1ed. España: Mosby,1993. ISBN 84-8086-031-6.

[30] FRANCISCATTO, P. C. Caracterização das qualidades de radiação $X$ seguindo as recomendações da Norma IEC 61267 no laboratório de calibração do IPEN. Tese (Mestrado)- Instituto de Pesquisas 
${ }^{[31]}$ MINISTÉRIO DA SAÚDE. Portaria SVS MS 453: Diretrizes de proteção radiológica em radiodiagnóstico médico e odontológico do Ministério da Saúde. Diário Oficial da União. Brasília, de 02 de junho de 1998.

[32] BRASIL, MINISTÉRIO DA SAÚDE. Equipamentos médico-hospitalares e o gerenciamento da manutenção. Capacitação a distância. Brasília-DF: Série F. Comunicação e Educação em Saúde, 2002. (Coordenação: Prof. Dr. Saide Jorge Calil).

[33] NETO, A.T.B. Implantação de radiações de referência em uma máquina de raios-X diagnóstico médico para fins de calibração de dosímetros pessoais. 2005. $114 \mathrm{f}$. Dissertação (Mestrado em Ciências e Tecnologia das Radiações Minerais e Materiais Centro de Desenvolvimento da Tecnologia Nuclear - CDTN, Belo Horizonte, 2005.

[34] SHERER, M. A. S., VISCONTI, P. J., RITENOUR, E. R. Radiation Protection in Medical Radiography. 4. ed. St. Louis: Mosby, 2002.

${ }^{[35]}$ DOWN, S. B., TILSON, E. R. Pratical radiation protection and applied radiobiology. 2. ed. Philadelphia: W. B. Saunders Company, 1999.

[36] Soares, F.C.S.. Avaliação de dispositivos de proteção individual utilizados em radiologia diagnóstico. 2006. Dissertação (Mestrado) - Instituto de Pesquisas Energéticas e Nucleares, Universidade de São Paulo, São Paulo.

[37] ASSOCIAÇÃO BRASILEIRA DE NORMAS TÉCNICAS; INSTITUTO NACIONAL DE METROLOGIA, NORMALIZAÇÃO E QUALIDADE INDUSTRIAL. Guia para a expressão da incerteza de medição. 3.ed. Rio de Janeiro: ABNT, INMETRO, 2003.

${ }^{[38]}$ FUNDAÇÃO CERTI. Apostila do curso: Incerteza de medição. São Paulo, junho / 2004.

${ }^{[39]}$ NERSISSIAN, D. Y. Determinação das dimensões do ponto focal de tubos de raios $X$ utilizando um sensor CCD e o método das funções de transferência. 2004. Tese (Doutorado) - Instituto de Pesquisas Energéticas e Nucleares, Universidade de São Paulo, São Paulo.

[40] NATIONAL INSTRUMENTS CORPORATION. Manual de treinamento do LabVIEWTM Básico I. National Instruments Corporation, 2001

${ }^{[41]}$ REVISTA SABER ELETRÔNICA. Disponível em:

http://www.saberelétronica.com.br/secoes/leitura/1643. Consulta em: 15/03/2012.

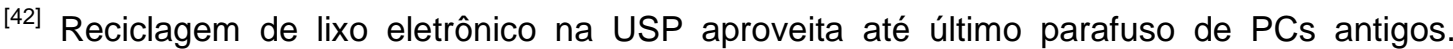
Disponível em: http://tecnologia.uol.com.br/ultimas-noticias/redacao/2010/02/22/reciclagemde-lixo-elétronico-na-usp-aproveita-ate-ultimo-parafuso-de-pcs-antigos.jhtm. Consulta em: $15 / 03 / 2012$

${ }^{[43]}$ FINCO, A. Projeto "e-waste - lixo eletrônico" do SENAI/SC em São Miguel do Oeste. ETech: tecnologia para a competitividade industrial, v.3, n.1, p. 79-97, 2010.

[44] PIDONE, L. A. Utilização das diretivas ROHS e WEEE para equipamentos eletromédicos fabricados no brasil. 2011. Dissertação (Mestrado) - Instituto de Pesquisas Energéticas e Nucleares, Universidade de São Paulo, São Paulo.

${ }^{[45]}$ RADCAL CORPORATION. Disponível em: http://www.radcal.com/rc_chambers.html. Consulta em: 05/03/2012.

${ }^{[46]}$ RADCAL CORPORATION. Disponível em: http://www.radcal.com/dyna.html. Consulta em: 05/03/2012. 
${ }^{[47]}$ APPRAISERS LASER. Disponível em: http://www.appraiserslaser.com/m-d-smarttool24inch-digital-level.html. Consulta em: 05/03/2012.

${ }^{[48]}$ FLUKE BIOMEDICAL. Disponível em: http://www.flukebiomedical.com/biomedical/usen/ Diagnostic-Imaging-QA/Radiography/Fluoroscopy/07-434.htm?PID=54294. Consulta em: 05/03/2012.

${ }^{[49]}$ YXLON International. Disponível em: http://www.yxlon.com/Resources/Products/X-raytubes-and-generators-en/Y_MG_325_452_ProductSheet_A4_EN_IL04-en. Consulta em: 05/03/2012.

[50] YXLON International Disponível em: http://www.yxlon.com/Resources/Products/X-raytubes-and-generators-en/Y_TU_320-D05_ProductSheet_A4_EN_HC01-en.pdf. Consulta em: 05/03/2012.

[51] ALVARENGA, Frederico L. ; OLIVEIRA, Paulo Márcio C. ; SQUAIR, Peterson Lima ; SOARES, Carlos M. ;SILVA, Teógenes Augusto da. Análise Metrológica de Testes de Constância em Aparelho de Raios $X$ Médico Convencional. In: INAC - International Nuclear Atlantic Conference, 2005, Santos - SP. INAC - International Nuclear Atlantic Conference, 2005.

${ }^{[52]}$ MEDWOW. Disponível em: http://pt.medwow.com/med/x-ray-generator/vmi/pulsarplus/9270.model-spec. Consulta em: 05/03/2012.

${ }^{[53]}$ VARIAN MEDICAL SYSTEMS. Disponível em: http://www.varian.com/media/xray/products/pdf/ rad68.pdf. Consulta em: 05/03/2012.

${ }^{[54]}$ VARIAN MEDICAL SYSTEMS. Disponível em: http://www.varian.com/us/xray/products/ immediate delivery/radiographic rad fluoro.html\#varian. Consulta em: 05/03/2012.

${ }^{[55]}$ LEADMEC MECÂNICA INDUSTRIAL. Disponível em: http://www.leadmecanica.com.br Imain.aspx\#. Consulta em: 05/03/2012.

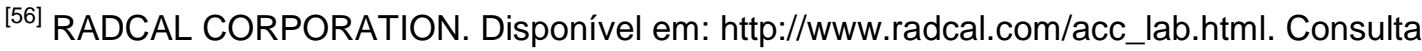
em: 05/03/2012.

[57] ALCÂNTARA, A.C. Sistema automatizado para ensaios de reprodutibilidade e linearidade em equipamentos de radiodiagnóstico. Dissertação monográfica (Graduação em Tecnologia em Saúde) - Departamento de Saúde, Faculdade de Tecnologia de Sorocaba, Sorocaba, 2010.

[58] INTERNATIONAL ELECTROTECHNICAL COMMISSION. Medical diagnostic $\boldsymbol{x}$ rayequipment - Radiation Conditions for use in the determination of characteristics. Geneva, Switzerland, 2005 (IEC-61267)

[59] INTERNATIONAL ELECTROTECHNICAL COMMISSION. Inherent filtration of X-ray equipment. Pergamon Press, New York, 1999 (IEC-60522).

[60] ASSOCIAÇÃO BRASILEIRA DE NORMAS TÉCNICAS. "Requisitos gerais de competência para laboratórios de ensaio e calibração". ABNT, Rio de Janeiro, 2005 (ABNT NBR ISO IEC 17025).

[61] B.R. ARCHER, J.I.THORNBY, S.C. BUSHONG. Diagnostic X-Ray Shielding Design Based on an Empirical Model of Photon Attenuation. Health Phys. 44, 507- 517 (1983).

[62] B.G. GILMORET, K. CRANLEY. Errors in the determination of total filtration of diagnostic x-ray tubes by the HVL method. Phys. Med. Biol. 35, 999-1015 (1990).

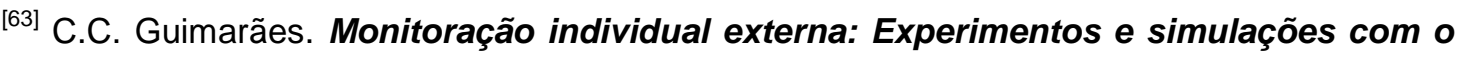


método de Monte Carlo. Tese (doutorado em Física) - Instituto de Física, Universidade de São Paulo. 211 p. (2005).

${ }^{[64]}$ 2007LS01PR004Y - procedimento de ensaio para determinação da primeira camada semiredutora

${ }^{[65]}$ ASSOCIAÇÃO BRASILEIRA DE NORMAS TÉCNICAS. "Avaliação de conformidade Requisitos gerais para ensaios de proficiência". ABNT, Rio de Janeiro, 2011 (ABNT NBR ISO IEC 17043).

[66] Associação Brasileira de Normas Técnicas (ABNT), Instituto Nacional de Metrologia, Normalização e Qualidade Industrial (INMETRO), Guia para Expressão das Incertezas de Medição, $3^{\mathrm{a}}$ edição, 2003.

[67] OLIVEIRA, P. M. C. de; et al., "Analysis of X-Ray Beam Parameters Used to Implement Reference Radiations for Calibrating Dosimetric Systems for Diagnostic Radiology". IRPA: 2008 Internacional. 